Historic, archived document

Do not assume content reflects current scientific knowledge, policies, or practices. 



\section{UNITED STATES DEPARTMENT OF AGRICULTURE}

CIRCULAR No. 100

Washington, D. C.

October, 1929

\section{BUSINESS ANALYSIS \\ OF THE TOBACCO GROWERS' COOPERATIVE ASSOCIATION}

\section{JOHN J. SCANLAN}

Agricultural Economist, Division of Cooperative Marketing Bureau of Agricultural Economics

and

J. M. TINLEY Collaborator
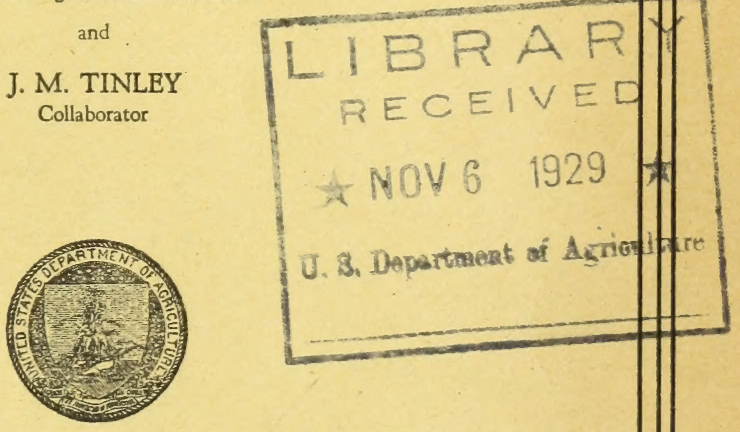


\title{
BUSINESS ANALYSIS OF THE TOBACCO GROWERS' COOPERATIVE ASSOCIATION
}

\author{
By JoHn J. Scanlan, ${ }^{1}$ Agricultural Economist, \\ Division of Cooperative Marketing, Bureau of Agricultural Economics,
} and J. M. TINLEY, Collaborator

\section{CONTENTS}

Introduction

Purpose of this study

Procedure of the study

The tobacco of the tri-

Production by quantity and type........-

Manufactured products

Foreign trade

Formation of the Tobacco Growers' Coopera-

tive Association

Factors leading to organization........-

Developments during organization period and membership campaign

Formation of organization committee....

Membership campaign .

The internal organization ........................ Directors.

Departments.

Subsidiary warehousing corporations

Type of organization

Members' responsibility for failure of the association....................................... Conditions of farm population in the

tri-State area
The association's receipts of tobacco......

Management policies and their relation to failure of association.

Experience and attitude of directors.....

Membership policies

Legal status of the association.............

Advances and payments to members....

Operating policies and practices........-.

Costs of operation
Page

Management policies and their relation to failure of association-Continued.

Price and sales policy ......................

Member and nonmember prices.............

Opposition to the association .................. Progress during operation of the association. Changes in policies......................... Attempts at reorganization............... Receivership granted Causes contributing to failure................. Results of the association.................... Benefits derived from operation of the association Harmful effects of the association........ Future organization
Growers' interest in cooperative market-

Manufacturers' interest in cooperative marketing interest in cooperative A suggested plan for the successful coopperative marketing of tobacco......... Summary

Articles of incorporation of Tobacco Growers' Cooperative Association.....

Tobacco Growers' Cooperative Association agreement

Member's agreement with the associa

Modified order for receivers Literature cited............................... 151

\section{INTRODUCTION}

This study of the Tobacco Growers' Cooperative Association (the tri-State association) of Virginia, North Carolina, and South Carolina was undertaken at the request of agricultural leaders and business interests of the States in which the association operated and of its receivers. The study was begun in August, 1927, as a part of the program of economic research in farmers' cooperative business organizations conducted by the Division of Cooperative Marketing

1 Credit is due J. M. Macon and S. Gatling of the office of the receivers of the Tobacco Growers' Cooperative Association for assistance in helping to find and compile data from the association files and records; to F. B. Wilkinson of the tobacco section of the Bureau of Agricultural Economies for information in regard to tobacco grades and classification; to H. M. Bain for contributing material dealing with the legal phases; to various members of the Bureau of Agricultural Economics and especially of the Division of Cooperative Marketing for valuable suggestions and cooperation; and to Julia A. Hampton for much assistance in compiling statistical material in the preparation of this circular. 
of the Bureau of Agricultural Economics. This division has made, and is making, similar studies of cooperative associations handling various farm products, but this is the first business-analysis study which it has made of a cooperative tobacco-marketing association.

\section{PURPOSE OF THIS STUDY}

To enable other cooperators and cooperatives, especially those dealing with tobacco, to benefit by the policies, mistakes, and experiences of this association the economic and social background in Virginia and the Carolinas, the inception of the association, its formation, organic set-up, operations, membership relations and policies, problems, and difficulties are analyzed in considerable detail. Special effort has been made to emphasize the conditions and policies that led to the suspension of operation of the association in June, 1926.

\section{PROCEDURE OF THE STUDY}

Four main sources of information and data were used in preparing this bulletin: The department's records, the files and records of the association, interviews with officials and others in intimate touch with the association's operations, and a membership study. General information and data relating to the tobacco industry as a whole were obtained from the department libraries and from publications of the various States and of the United States Department of Agriculture. Statistical material relating to the production, prices, and consumption of tobacco was assembled, analyzed, and studied.

The receivers of the association made available all the records and files covering the entire period of the organization's operations. Careful and detailed examination was made of all information in the association's offices pertaining to the phases of its organization and operations studied, and interviews were held with most of the former directors of the association and with many men who had been connected with it as executives or in other official or advisory capacities or as employees; and interviews were also held with other men who were active in this tobacco area. Many of these men had been in close touch in some way with the organization; others, interested but free from bias, had, at a distance, watched the rise and fall of this cooperative enterprise. These men included bankers, lawyers, merchants, editors, agricultural leaders, members of the staffs of State colleges, State and county officials, tobacco buyers, representatives of tobacco companies and of other business interests, and many nonmember tobacco growers in the tri-State area. To learn the attitudes of the members, about 700 members were interviewed over a territory covering practically every county in which the association had operated. Of the 700 questionnaires filled in during these interviews, 643 were tabulated, and give what is considered a fair and representative sample of the attitude of the members of the tri-State association as a whole. For purposes of comparison several other tobacco cooperatives were visited. An attempt was made to secure data in regard to tobacco grades and prices from several of the larger tobacco manufacturers, but without success. 


\section{THE TOBACCO OF THE TRI-STATE AREA}

\section{PRODUCTION BY QUANTITY AND TYPE}

The three States, Virginia, North Carolina, and South Carolina, include some of the most important tobacco-growing districts in the world both as to quality and quantity of tobacco. These States, comprising the so-called tri-State area, during the 4-year period, 1922-1925, produced 39.5 per cent of the total United States production of tobacco. North Carolina alone produced 24.4 per cent of the United States output and 61.6 per cent of the production of the tri-State area. (Fig. 1.)

Practically no class of tobacco is grown in the Carolinas except the flue cured, but in Virginia there are three classes-flue-cured, fire cured, and two types of the air-cured class-Burley and Virginia sun-cured. Of these the flue-cured is the most important, comprising 63 per cent of the total State tobacco production; dark fired is second in importance, amounting to 31 per cent. The sun-cured and

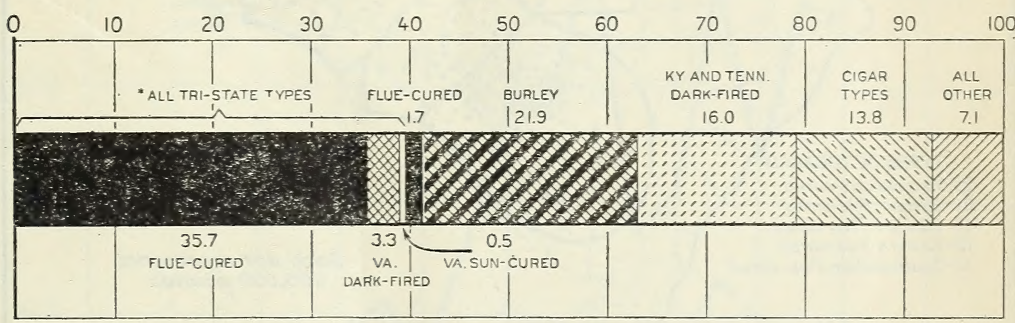

- a small ovantity of burley tobacco is grown in the tri-state area

Figure I.-Tobacco Production by Types, United States and Tri-State AReA, AVERAge 1922-1925

The tri-State area during the operation of the association produced 39.5 per cent of the total United States production of tobacco. It produced over 95 per cent of the total United States production of flue-cured tobacco as well as comparatively small quantities of dark-fired, sun-cured, and Burley tobaccos.

Burley types together make up the remainder of less than 6 per cent. From 1922 through 1925, 90 per cent of the production of the three States was flue-cured tobacco. This was over 95 per cent of the United States production of that class.

The distribution of tobacco production by quantity and types in Virginia, North Carolina, and South Carolina, in 1924, is shown in Figure 2. The production is largely concentrated in the central and south-central part of Virginia, in the north-central and eastern part of North Carolina, and in the northeastern part of South Carolina.

There has been a continual increase in the total acreage and production of tobacco in the United States. (Fig. 3.) From a yearly average production of $546,000,000$ pounds for the period 1890 to 1899 , the production increased to an average of $1,322,000,000$ pounds for the period 1920 to 1928 . This was an increase of 142 per cent in less than 30 years.

Figure 4 shows the production of the more important types of tobacco from 1909 to $1929 .{ }^{2}$ With the exceptions of the flue-cured

${ }^{2}$ Data on production by types prior to 1909 is not available. 


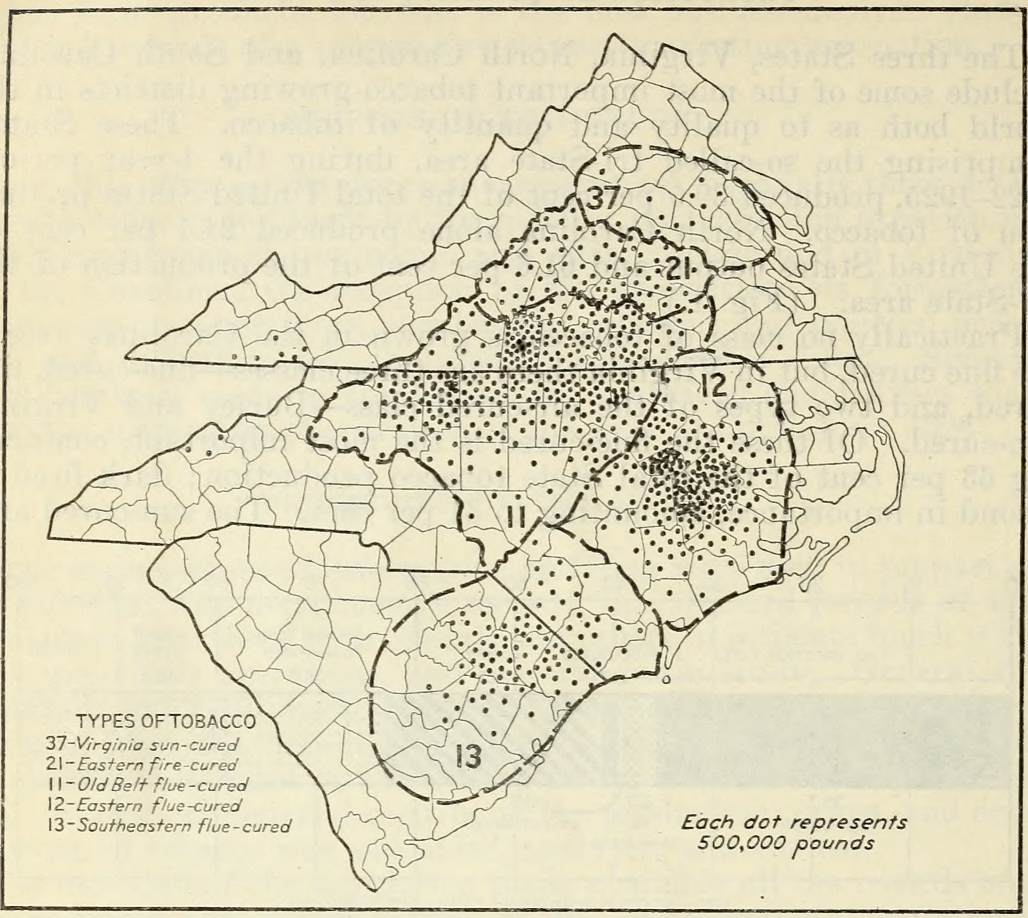

Figure 2.-Production of Tobacco in the Tri-State Area, by TYPes, 1924

The production of tobacco in the tri-State area is largely concentrated in the central and south-central part of Virginia, in the north-central and eastern part of North Carolina, and in the northeastern part of South Carolina. With the exception of some sun-cured and dark-fired tobaccos in Virginia and a smali quantity of Burley tobacco, most of the production is of the fiue-cured types.

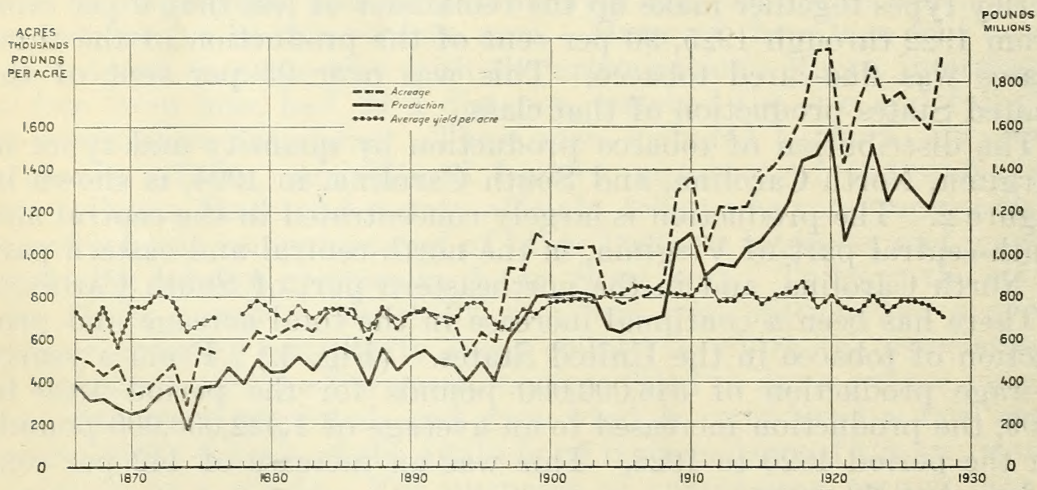

Figure 3.-Total United States Acreage, Production and average YIELD PER ACRE OF TOBACC 0, 1866-1928

There has been a more or less continuous increase in the total acreage and production of tobacco in the United States. 
and Burley types, and possibly the cigar types, the production of all other types shows a decrease from the pre-war average. In 1909 the production of flue-cured and Burley tobaccos accounted for 46.2 per cent of all United States tobacco; in 1927 the percentage was 72.8. The data available by types of tobacco shows that the year-to-year fluctuation in production of all United States tobacco is largely accounted for by the changes in the production of flue-cured and Burley tobaccos. The increase in Burley production has been small as compared with that of flue-cured tobacco. The reason for the smaller increase of Burley is that in normal years in the past a much

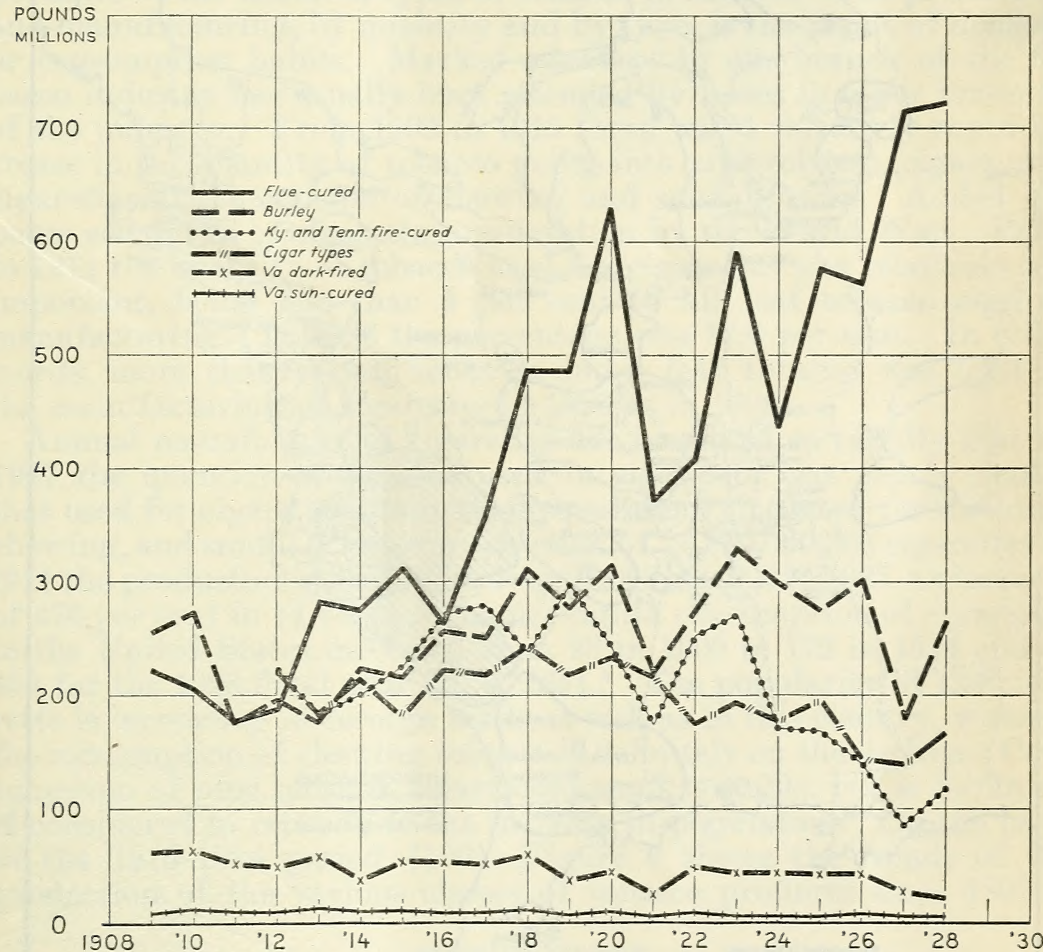

\section{Figure 4.-PRODUCTION OF TOBACCO IN THE UNITED STATES bY PRINCIPAL} TYPES, 1909-1928

Flue-cured tobacco has shown a rapid increase in production since the pre-war period, whereas the production of most other types has declined.

smaller portion of this type of tobacco has been found suitable for manufacture into cigarettes. But the increased demand for the cigarette types of tobacco has resulted in a larger part of the Burley being used in cigarettes.

Increase in the production of flue-cured tobacco has been phenomenal. From an output of $283,000,000$ pounds in 1913 the production climbed steadily to $692,000,000$ pounds in 1927 , an increase of 145 per cent in 14 years. In 1909 the production of the flue-cured class was 21.1 per cent of the total United States production; in 1927 it had increased to 55.9 per cent. 


\section{MANUFACTURED PRODUCTS}

Flue-cured tobacco enters mainly into exports and into the manufacture of cigarettes, although some grades are used as wrappers for chewing tobacco and other grades are used for smoking tobaccos. The type of dark-fired tobacco grown in Virginia is used chiefly for

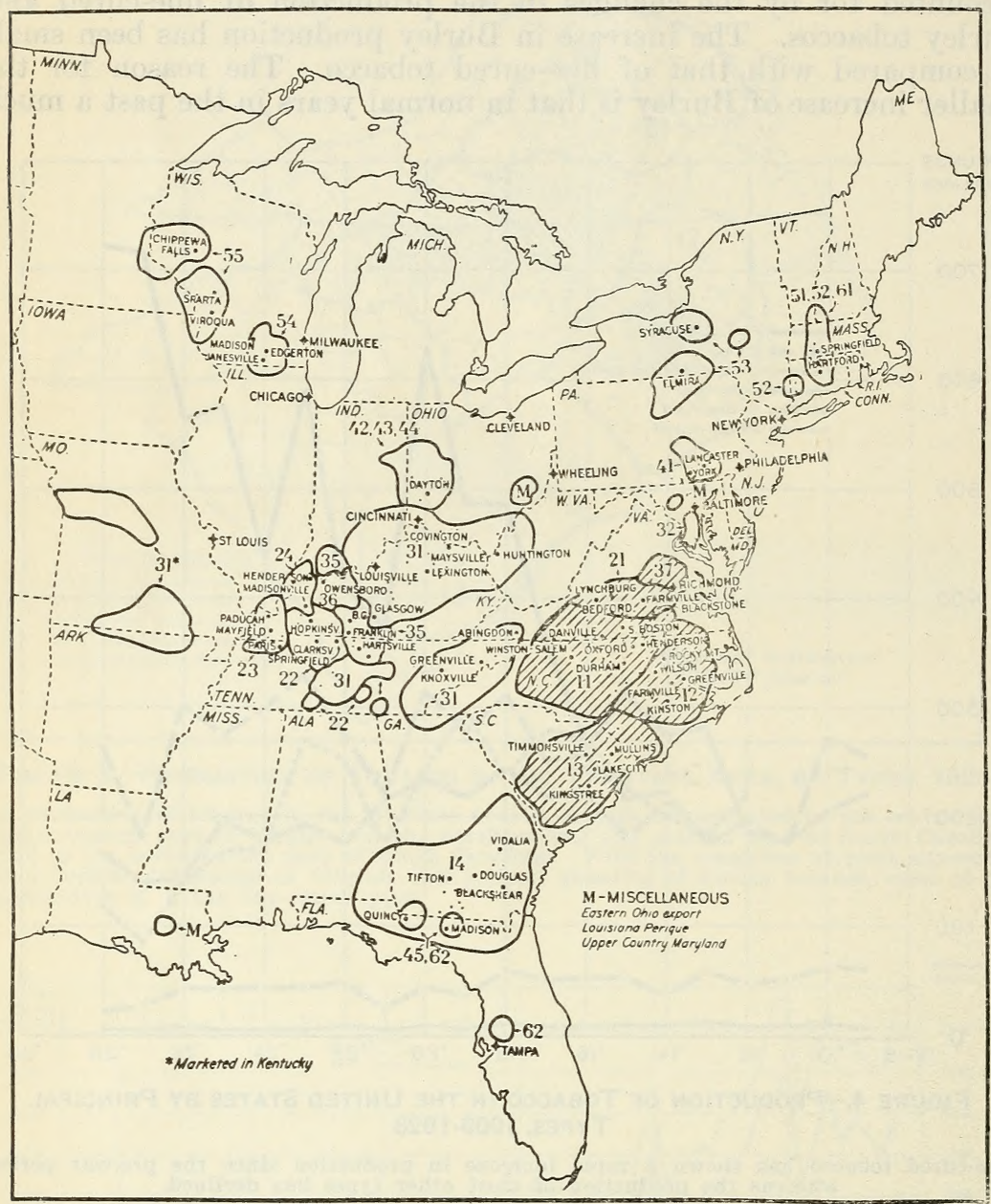

Figure 5.-Types of TOBacco by Production AREAS, 1928

Tobacco is grown in many areas east of the Mississippi River. The cigarette, smoking, chewing, and snuff types of tobacco are produced chiefly in the South Atlantic States and in Kentucky and 'Tennessee, while the cigar types are grown mainly in the North Atlantic area and in Ohio and Wisconsin. Most of the tobacco of the flue-cured type is grown in the tri-State area (the shaded part).

snuff and smoking tobacco in the United States and for export. Other types of dark-fired tobaccos are grown in Kentucky and Tennessee. Virginia sun-cured tobacco is for the most part used in the manufacture of chewing tobacco. It will be seen from Figure 5 that the cigarette, smoking, chewing, and snuff types of tobacco are pro- 
duced chiefly in the South Atlantic States and in Kentucky and Tennessee, whereas the cigar types are grown mainly in the north Atlantic area and in Olio and Wisconsin. Very little tobacco is grown west of the Mississippi River.

Probably no other factor has had as important an effect upon the production of tobacco in the tri-State area and in the United States during the last three decades as the change in consumption habits. Not only has the consumption of tobacco as a whole increased steadily since 1900 , but within recent years several important changes have occurred which have greatly influenced the relative quantity and inportance of the different types of tobacco produced. The production and manufacturing, by quantity and by type, is the result of demand or consumption habits. Marked advances in one branch of the to bacco industry has usually been attended by losses in other branches of the industry. From 1900 to 1915 there was a relatively rapid increase in the quantity of tobacco going into pipe tobacco, cigars, and cigarettes at the expense of chewing and snuff tobacco. Added impetus was given to cigarette consumption by the World War. Prior to 1914 the quantity of tobacco used for cigarettes was relatively unimportant, being less than 5 per cent of all leaf tobacco used in manufacturing. In 1926 the percentage was 37.6 per cent. In other words, more than eleven times as much leaf tobacco was used in the manufacturing of cigarettes in 1926 as in 1909.

Annual manufacture of cigarettes has increased so rapidly that by 1927 the quantity of tobacco used in cigarettes was nearly double that used for cigars and more than equal to all that used for smoking, chewing, and snuff. From a production of $16,870,000,000$ cigarettes in 1914 the production increased to over $97,000,000,000$ in 1927, an increase of 476 per cent in 14 years. The per capita consumption of cigarettes in the United States increased from 28 in 1900 to 172 in 1914 and to 838 for the 1928 fiscal year $(2, p .135) .^{3}$ The popularity of the cigarette is increasing in foreign lands as well as in this country, whereas the consumption of chewing tobacco is definitely on the decline. Consumption of pipe tobacco, cigars, and snuff is stable, but is declining if considered in relation to the increase in population. On the basis of the 1910-1914 period (100), Figure 6 shows the trends of the production of the various classes of tobacco products since 1897 .

\section{FOREIGN TRADE}

Although a larger proportion of the United States production of dark Kentucky and Tennessee, dark Virginia, and Maryland and Ohio export tobacco is exported than of the flue-cured type, the latter constitutes over half of the total exports of tobacco. During the 5-year period 1922-1927, 45.8 per cent of the production of the fluecured types was exported. From 1922 to 1927 the exports of fluecured tobacco increased from $180,000,000$ pounds to $302,000,000$ pounds.

Some of the foreign countries are attempting to promote and encourage tobacco production in their States and colonies. These attempts have proved more or less successful, at least temporarily, for some of the dark tobaccos and, as a consequence, the foreign demand

${ }^{3}$ Reference is made by italic numbers in parentheses to Literature Cited, p. 151. 
for some of the dark types of United States tobacco has been declining. This has affected the foreign competition for dark types of American-grown tobacco. On the other hand, the trend in tobacco consumption in foreign countries as well as in America is toward cigarettes and away from other forms. This tends to increase the demand for flue-cured tobacco and to decrease that for the heavier and darker types.

The tobacco produced in foreign countries is usually of an inferior quality, and the foreign demand for America's tobaccos continues

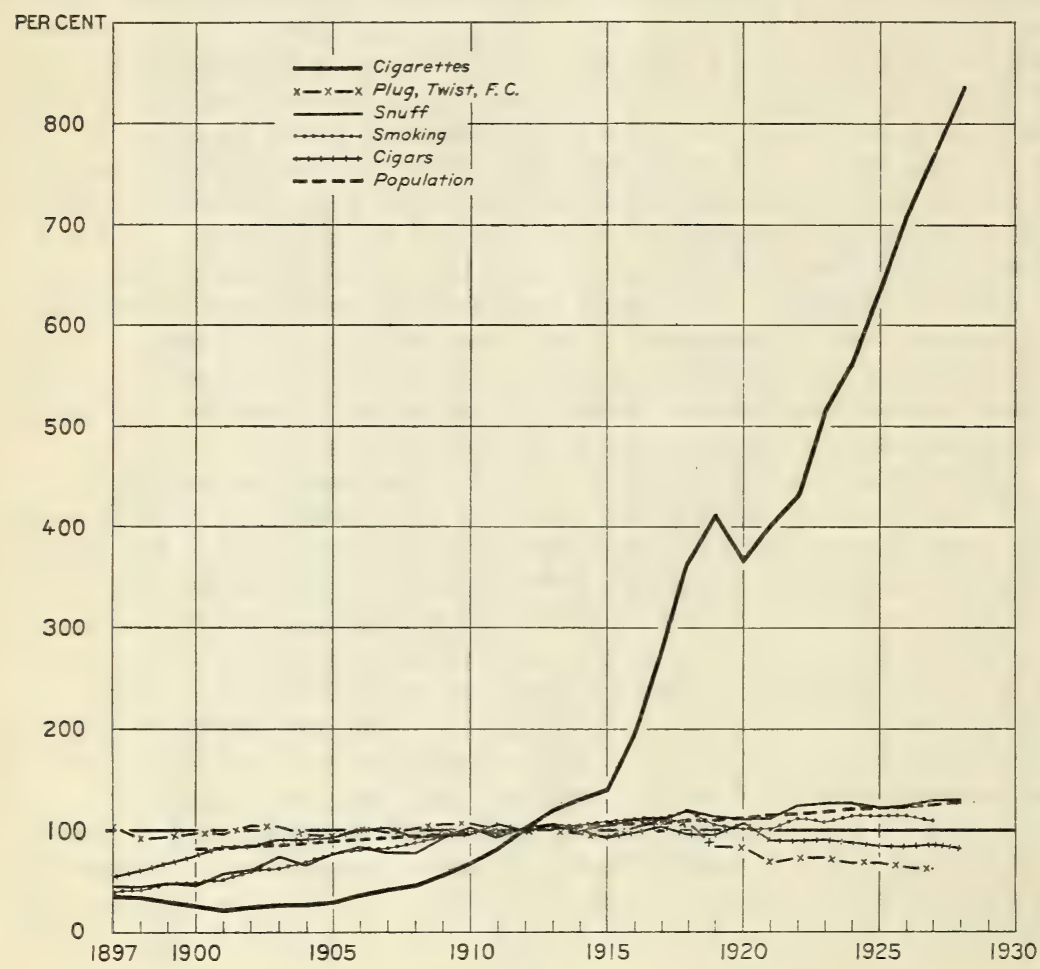

FIGURE 6.-PRODUCTION OF PRINCIPAL TOBACCO PRODUCTS, 1897-1928

The production of cigarettes increased 476 per cent from 1914 to 1927 , while the production of other tobacco products has increased very little for some years and has declined for others, especially for plug, twist, and fine cut.

because of their high quality and because they fit into the needs of other countries to blend with their domestic or imported tobaccos.

The United Kingdom is the best customer of the United States for leaf tobacco, taking about a third of the total exports and nearly half of all the flue-cured tobacco exported. China is the second largest importer of United States tobacco, taking chiefly the fluecured types. The imports of tobacco into the United States consist chiefly of special types, such as Turkish cigarette leaf and cigar leaf. Imported tobacco comes chiefly from the Dutch East Indies, Cuba, Greece, and Turkey. In addition, tobacco is shipped in from Porto Rico and the Philippine Islands. 


\section{FORMATION OF THE TOBACCO GROWERS' COOPERATIVE ASSOCIATION}

\section{FACTORS LEADING TO ORGANIZATION}

Conditions after the World War stimulated and hastened the formation of cooperative tobacco-marketing associations in nearly all of the important tobacco-producing areas of the United States. It is estimated that less than 1 per cent of the tobacco crop of 1919 was delivered to cooperative associations and more than 48 per cent of the crop of 1922 . In 1925 tobacco cooperatives had a total estimated membership of 300,000 and were transacting an annual business estimated at $\$ 90,000,000$. Among the tobacco organizations were two of the largest cooperative-marketing associations in the United States in regard to number of members $(3, p .61-62)$.

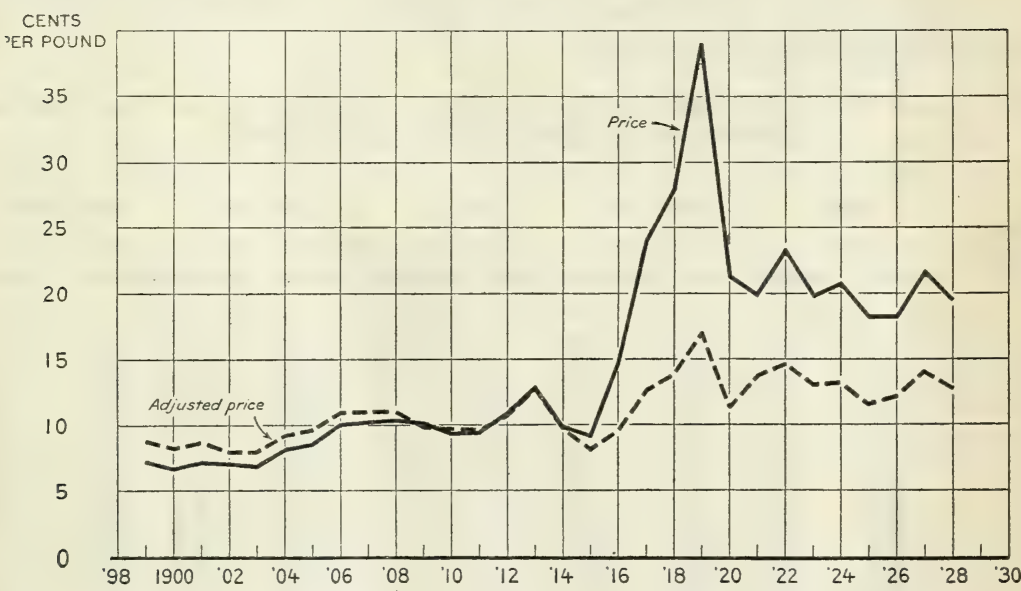

Figure 7.-Actual and Adjusted Price of United States Tobacco, 1899-1900-1928-29

Adjusted prices are the United States Department of Agriculture December 1 prices adjusted by the Bureau of Labor Statistics All-Commodity Index Number crop year basis $(1910-11$ to $1914-15=100)$. Both the average actual and adjusted price of United States tobacco show upward trends. The sudden drop of tobacco prices from 39 cents in $1919-20$ to 21.2 cents in 1920-21 created much distress among the tobacco growers.

There were two main causes for the quick growth of the cooperative movement among tobacco growers: (1) The sudden drop in tobacco prices and (2) dissatisfaction with the loose-leaf auction-floor method of selling tobacco.

\section{TOBACCO PRICES}

During the World War, prices of tobacco, like those of other farm products, reached abnormal heights. In fact, the prices of tobacco increased even more than those of most other farm products and more than the cost of living. Then the sudden decrease in foreign demand, the rapid price deflation in the United States, together with a production far in excess of domestic requirements, caused a disastrous fall in tobacco prices in 1920. The average price of all tobaccos fell from 39 cents in 1919-20 to 21.2 cents in 1920-21, a decrease of 45.6 per cent in one year. (Figure 7.) Table 1 shows the prices and pur- 
chasing power of all United States tobacco, Burley, flue-cured, Virginia dark-fired, and Virginia sun-cured tobaccos since 1909-10.

Living expenses and the cost of production remained at high levels, and this precipitous drop in prices for their chief and often sole cash crop created much dissatisfaction, discontent, and even distress and hardship among the tobacco growers of Virginia, North Carolina, and South Carolina, as well as in other tobacco-producing areas.

DISSATISFACTION WITH AUCTION-FLOOR METHOD OF SELLING

During recent years there has appeared a general dissatisfaction with the auction-floor system of marketing tobacco. The great bulk of tobacco is sold under this system, although some tobacco is sold in the packed form to the highest bidder at public auction, some at a closed-bid auction and some on the farms to buyers who visit the producing districts $(4, p .43 \%)$.

TABLE 1.-Actual and adjusted prices in cents per pound for selected types of tobacco in the United States, 1909-1928 ${ }^{1}$

\begin{tabular}{|c|c|c|c|c|c|c|c|c|c|c|}
\hline \multirow{2}{*}{$\begin{array}{l}\text { Year be- } \\
\text { ginning } \\
\text { July } 1\end{array}$} & \multicolumn{2}{|c|}{ Burley } & \multicolumn{2}{|c|}{ Sun-cured } & \multicolumn{2}{|c|}{ Dark-fired } & \multicolumn{2}{|c|}{ Flue-cured } & \multicolumn{2}{|c|}{ All tobacco } \\
\hline & Actual & Adjusted & Actual & Adjusted & Actual & Adjusted & Actual & Adjusted & Actual & Adjusted \\
\hline $\begin{array}{l}1909 \\
1910 \\
1911 \\
1912 \\
1913 \\
1914 \\
1915 \\
1916 \\
1917 \\
1918 \\
1919 \\
1920 \\
1921 \\
1922 \\
1922 \\
1924 \\
1925 \\
1926 \\
1927 \\
1928\end{array}$ & $\begin{array}{r}13.4 \\
9.6 \\
7.5 \\
11.0 \\
12.3 \\
8.1 \\
9.5 \\
15.5 \\
26.5 \\
32.6 \\
24.5 \\
13.4 \\
22.4 \\
25.2 \\
21.4 \\
21.3 \\
19.0 \\
13.1 \\
26.0 \\
27.2\end{array}$ & $\begin{array}{r}13.2 \\
10.1 \\
7.7 \\
11.0 \\
12.4 \\
8.2 \\
8.6 \\
10.2 \\
14.2 \\
16.3 \\
10.8 \\
7.3 \\
15.7 \\
16.2 \\
14.2 \\
13.8 \\
12.2 \\
8.9 \\
17.5 \\
17.8\end{array}$ & $\begin{array}{r}8.4 \\
8.5 \\
9.0 \\
8.0 \\
8.5 \\
6.5 \\
8.0 \\
14.0 \\
28.5 \\
20.5 \\
28.0 \\
10.0 \\
19.0 \\
14.3 \\
13.2 \\
14.6 \\
16.4 \\
9.5 \\
13.1 \\
8.5\end{array}$ & $\begin{array}{r}8.1 \\
8.8 \\
9.2 \\
7.9 \\
8.4 \\
6.5 \\
7.1 \\
9.1 \\
15.0 \\
10.1 \\
12.1 \\
5.3 \\
13.1 \\
9.0 \\
8.6 \\
9.3 \\
10.3 \\
6.3 \\
8.7 \\
5.5\end{array}$ & $\begin{array}{r}7.8 \\
8.0 \\
8.4 \\
7.8 \\
7.0 \\
7.3 \\
8.0 \\
10.4 \\
17.0 \\
17.7 \\
25.0 \\
9.9 \\
18.7 \\
18.8 \\
18.1 \\
19.4 \\
16.2 \\
7.8 \\
9.9 \\
10.0\end{array}$ & $\begin{array}{r}7.5 \\
8.3 \\
8.6 \\
7.7 \\
6.9 \\
7.3 \\
7.1 \\
6.7 \\
8.9 \\
8.7 \\
10.8 \\
5.3 \\
12.9 \\
11.9 \\
11.8 \\
12.3 \\
10.2 \\
5.2 \\
6.5 \\
6.5\end{array}$ & \begin{tabular}{r|}
9.23 \\
10.28 \\
11.31 \\
15.57 \\
18.25 \\
11.29 \\
10.55 \\
19.04 \\
30.54 \\
34.25 \\
44.58 \\
21.14 \\
21.74 \\
29.00 \\
22.27 \\
22.46 \\
20.02 \\
25.60 \\
21.30 \\
17.90
\end{tabular} & $\begin{array}{r}8.9 \\
10.6 \\
11.6 \\
15.3 \\
18.1 \\
11.2 \\
9.4 \\
12.3 \\
16.1 \\
16.8 \\
19.3 \\
11.3 \\
15.0 \\
18.3 \\
14.5 \\
14.3 \\
12.6 \\
17.1 \\
14.1 \\
11.7\end{array}$ & $\begin{array}{r}10.1 \\
9.3 \\
9.4 \\
10.8 \\
12.8 \\
9.8 \\
9.1 \\
14.7 \\
24.0 \\
28.0 \\
39.0 \\
21.2 \\
19.9 \\
23.2 \\
19.9 \\
20.7 \\
18.2 \\
18.2 \\
21.2 \\
19.5\end{array}$ & $\begin{array}{r}9.8 \\
9.6 \\
9.6 \\
10.6 \\
12.7 \\
9.7 \\
8.1 \\
9.5 \\
12.6 \\
13.8 \\
16.9 \\
11.3 \\
13.7 \\
14.6 \\
13.0 \\
13.1 \\
11.5 \\
12.1 \\
14.0 \\
12.7\end{array}$ \\
\hline
\end{tabular}

1 U. S. Department of Agriculture Yearbooks, 1910-1928. Actual prices adjusted by dividing by the Bureau of Labor Statistics All-Commodity Index Number, crop year, July, 1910-June, $1915=100$.

2 Preliminary.

No uniform or generally accepted grade designations are used, and no one central market exists which can be used as a basis for market quotations, nor is there available to growers any market information service. A futures market in tobacco has never been developed. Redried tobacco is a nonperishable commodity, and large stocks are carried over from one year to another by the large tobacco companies and dealers. The bulk of the demand for tobacco for manufacturing is concentrated in the hands of a few powerful companies. ${ }^{4}$

Usually as soon as the farmer's tobacco is cured he hauls it to the local market, which is open for a few months only. It is placed in

4 The Federal Trade Commission (13) in its report of Dec. 11, 1920, on the tobacco industry states: "While opinions differ as to the existence of competition among the buyers of leaf tobacco, and no conclusive evidence of collusion to bring about the decline is at hand, attention should be called to the fact that in each of the growing areas the buying is centered in very few hands." 
baskets or piles in long rows on the auction floor. The buyers, from a few to a dozen or more in number, either buying independently (often for later resale) or as representatives of the large companies or manufacturers, more along the rows of tobacco baskets and piles, quickly looking at and possibly feeling or smelling of each pile in which they may be interested. They bid on it or pass it by. The piles are sold rapidly-at times a minimum of 240 or more sales an hour is made by the auctioneer. Needless to say, with only a relatively few buyers, with no grading system or market information service, and with the rapid method of selling, gross inequalities in prices occur, and the system is open to grave and serious abuses. It is variously estimated that the six large tobacco companies ${ }^{5}$ purchase directly from 80 to 90 per cent of the total rolume of tobacco offered for sale $(13, p .51-52)$.

Attention has been drawn to the fact that the auction-floor markets are in operation for only a few months. In this short period farmers have to sell their tobacco; or, if dissatisfied with prices, they can hold it over to the following season (which for many reasons is seldom done) or send it later to markets in later marketing areas. The heavy costs of transportation practically preclude the latter alternative.

The economic condition of the tobacco farmers of the South is such that the majority of them are forced to sell their tobacco as soon as it is ready for marketing, regardless of the price. Most of them have mortgaged an appreciable percentage of their cash crops, and loans become due as soon as the crop is sold. "Time merchants," bankers, and landlords are naturally anxious to receive payment as soon as possible, and frequently bring pressure to bear on the debtor to sell his crop at the earliest possible date.

Tobacco in the green state is liable to rapid deterioration unless redried or frequently "turned." Most growers can not afford to have their tobacco redried, and in any case the redrying of small parcels is much more expensive than the redrying of large orders. These conditions obviously make it still less possible for farmers acting individually to withhold their tobacco from the market if dissatisfied with prevailing prices. Only when they act collectively can they hope to supply themselves with the equipment and facilities necessary for the successful carrying of tobacco over from seasons of surplus to seasons of deficiency.

It is the possession of redrying equipment, storage facilities, and large reserves of capital which enables the large companies to purchase heavily in years of surplus production when prices are low and thus provide against years of lean crops and high prices. The manufacturers do not have immediate need for the crop just harvested, except for conditioning, as the bulk of it is neither required nor ready for manufacturing for a year or more after it is grown.

On the whole, the farmers are practically forced to sell their tobacco at whaterer price may prevail when their tobacco is ready to market. The inability of the majority of the farmers to withhold their tobacco from the market and the ability of the large companies

5 The six large tobacco companies are the American Tobacco Co.. P. Lorillard Co., the Liggetts \& Myer's Tobacco Co,, the R. J. Reynolds Tobacco Co., comprising the big four: the Imperial Tobacco Co. (Ltd.), and the British American Tobacco Co. (Ltd.). 
to stay off the market makes the auction-floor system of marketing tobacco essentially a buyer's market. This point is extremely important when regarded in relation to the success of cooperative marketing of tobacco. The arerage tobacco grower has little or no knowledge as to market conditions or as to what would be a reasonable price for his crop of tobacco, because little market information in regard to tobacco is available.

Looked at from all angles, the auction-floor system of marketing tobacco is far from satisfactory and is almost entirely in the favor of the large companies. The lack of a uniform system of grading tobacco operates to the disadvantage of both buyer and seller, but particularly to the disadvantage of the small grower, whose marketing position is weak. ${ }^{6}$

During the 1920 and 1921 marketing seasons the prices offered by the tobacco companies on the auction floors were, in the opinion of the farmers, unreasonably low. The buyers of the large tobacco companies were held responsible for the low prices. In certain sections of the tri-State area, the producers refused to sell at the prices offered and even threatened violence to the buyers and the destruction of warehouses. Indignation meetings were held, and there was a general demand for relief from existing conditions. Reports of the successful cooperative marketing of other farm products in other parts of the country were circulated, and this method of marketing tobacco was advocated as a remedy for the low prices then prevailing. Since the growers attributed the low prices to the auction-floor method of selling and to the control of the market by five or six large manufacturing companies, they considered it necessary to change the method of marketing and to control the marketing of tobacco by the organization of producer-owned cooperative associations.

\section{DEVELOPMENTS DURING ORGANIZATION PERIOD AND MEMBER- SHIP CAMPAIGN}

\section{FORMATION OF ORGANIZATION COMMITTEE}

The first important step toward organizing in the tri-State area was the appointment of a committee of leaders from the States of Virginia, North Carolina, and South Carolina for the purpose of studying the market situation and suggesting remedies for the existing unsatisfactory conditions. This committee met at Raleigh, N. C., in November, 1920, and decided to form a temporary organization to attempt to curtail the production the following year. The committee believed that this measure would bring only temporary relief, and

- Market inspection and grading of tobacco previous to sale has been conducted experimentally for two years, 1927 and 1928, at the Lynchburg, Va., market by the Virginia State Department of Agriculture and the United States Bureau of Agricultural Economics cooperatively. As the result of requests, this service will be extended to at least two other markets in Virginia in 1929, and its extension into other States is being considered. Under the market inspection and grading procedure, tobacco delivered to an auction-floor warehouse for sale is examined by a grader licensed by the United States Department of Agriculture to grade tobacco on the basis of United States standardized grades. The sales ticket is marked to show the grade, and this grade is announced by the warehouseman or auctioneer when the tobacco is offered for sale. The average prices by grades are posted at the close of each week. During the first two years of the experiment a farmer's tobacco was graded only at his request. The inspection and grading has met with such interest and approval of the Lynchburg tobacco grower's and dealers that the local tobacco board of trade on May 6, 1929 , went on record as favoring the policy of grading all tobacico received at its market except when farmers specifically request otherwise. 
that the solution of the problem lay in getting away from the existing system of marketing and in forming a cooperative-marketing organization.

On December 15, 1920, another meeting was held, this time at Richmond, Va. Speakers described the benefits and possibilities of cooperative marketing, emphasizing those of a strong, centralized cooperative organization. It was then decided to submit to the farmers of the three States at mass meetings proposals for the formation of such an association to handle the flue-cured, dark-fired, and sun-cured tobacco. These mass meetings were held at Lynchburg, Va., Raleigh, N. C., and Florence, S. C. Amid a great deal of enthusiasm, engendered by the hopes of the growers and the optimism of the speakers, plans were made to obtain the signatures of enough farmers to the contracts to make the organization effective.

Many prominent and influential men lent their assistance either directly or indirectly to the organization campaign. Among them were editors of farm and daily papers, State and county agricultural leaders, doctors, lawyers, bankers, and others who understood the economic situation of the tobacco grower and its consequent effect upon the prosperity of the area. Probably some of these men were unduly enthusiastic and optimistic about the possibilities of a tobacco cooperative, but there is no doubt as to their sincerity and good intentions.

\section{MEMBERSHIP CAMPAIGN}

Before the association could be formed, it was necessary that prospective members should sign an agreement providing for its formation with the provision that this agreement should be in effect if signed by growers representing at least one-half of the aggregate 1920 tobacco production of Virginia, North Carolina, and South Carolina by January 1, 1922. These agreements were not binding if this required 50 per cent sign-up was not obtained. Sufficient members in time to organize the association were not obtained, however, to handle the 1921 crop as had been planned if the sign-up was large enough by the summer of 1921 . The membership campaign was continued, and by January, 1922, over 64,000 farmers had signed contracts which presumably pledged about 57 per cent of the estimated production, on the basis of the 1920 crop, of flue-cured, darkfired, and sun-cured tobacco in the tri-State area. The association was incorporated under the cooperative law of North Carolina on February 9, 1922.

The result of the State mass meetings was the appointment of committees to supervise the membership campaign in the three States. Somewhat different methods of obtaining members were followed in the different areas; these different methods were later reflected in membership loyalty.

In Virginia a man was placed at the head of the State membership campaign at a definite salary and with an allowance to hire assistants. Mass meetings were held at country schoolhouses, at town halls, and at other points where producers could assemble. These meetinos were addressed by county agents, well-known farmers, business men, and State or county officials. After the meetings many farmers vol- 
untarily signed the contract. As a rule the policy was to get the morement well started in one county before the organization committee moved on to the next. Local volunteers, generally farmers working without pay, continued to obtain members among their neighbors and producers after the meetings. In 10 months 28,000 Virginia farmers were signed. They joined freely and without. much effort or solicitation on the part of the organizers. In some counties the large majority of the farmers joined the movement; in others, because of weak local leadership or other factors, the percentage was much smaller.

Conditions were not so favorable in North Carolina and South Carolina for a quick and easy sign-up. Prices in the flue-cured districts had made economic conditions more satisfactory than in the sun-cured and dark-fired districts. Strong, active State leaders were not obtained, and the membership campaigns were conducted in a way somewhat different from the way they were conducted in Virginia. Some growers, it is true, signed the contract at local meetings, and a great deal of work in obtaining members was done by volunteers. Many solicitors, however, were paid on a per member or per contract basis, receiving $\$ 1$ out of the $\$ 3$ membership fee. Some of these men, in their eagerness to sign the producers, were not conscientious or discriminating as to the type of grower solicited or in the methods employed to obtain signatures. Extravagant promises were made to the growers, some, no doubt, in all sincerity. Some solicitors told the producers that unless they joined before a certain date the fee would be increased or that there would be no market outside of the association at which to sell their product. It is claimed that a few even used insulting language if a grower refused to join. Many persons were induced to join who, under their credit and other economic conditions, could not be expected to deliver their tobacco, even if such had been their intention. In the cotton-producing district of North Carolina the canvassers induced members to join both the tobacco and cotton cooperatives by giving membership in both at the reduced rate of $\$ 5$. Members who had joined the tobacco growers' associations of Virginia, North Carolina, and South Carolina in 1920 were to be given credit against the entrance fee of the new association for whatever amount they har? paid.

The membership campaign did not terminate with the incorporation of the association, but continued in the different districts to the time of delivery. Thereafter new members were obtained whenever possible, but a continuous and systematic campaign was not carried on, as the efforts of the field service men were devoted to maintaining the membership morale and obtaining the delivery of tobacco by those who had signed. At the beginning of the second crop year the association had 88,533 members. During the next three years only 7,437 new members were obtained-2,471 in South Carolina, 2,202 in North Carolina, and 2,764 in Virginia. Considering the comparatively small number of tobacco growers in South Carolina, the subsequent membership campaigns in that State were more successful than in either Virginia or North Carolina. The data in Table 2, taken from data in the files of the association, show the number of contracts in force July 1 of each year in each State. 
TABLE 2.-Number of contracts with members in three States, July 1, 1922-1925

\begin{tabular}{|c|c|c|c|c|}
\hline Year & $\begin{array}{c}\text { South } \\
\text { Carolina }\end{array}$ & $\begin{array}{c}\text { North } \\
\text { Carolina }\end{array}$ & Virginia & Total \\
\hline 1922 & $\begin{array}{r}8,174 \\
8,889 \\
10,332 \\
11,360\end{array}$ & $\begin{array}{l}40,243 \\
43,858 \\
45,532 \\
46,060\end{array}$ & $\begin{array}{l}31,226 \\
35,786 \\
38,313 \\
38,550\end{array}$ & $\begin{array}{l}79,643 \\
88,533 \\
94,177 \\
95,970\end{array}$ \\
\hline
\end{tabular}

When the association passed into the hands of the receivers approximately 96,000 contracts had been signed. The distribution of

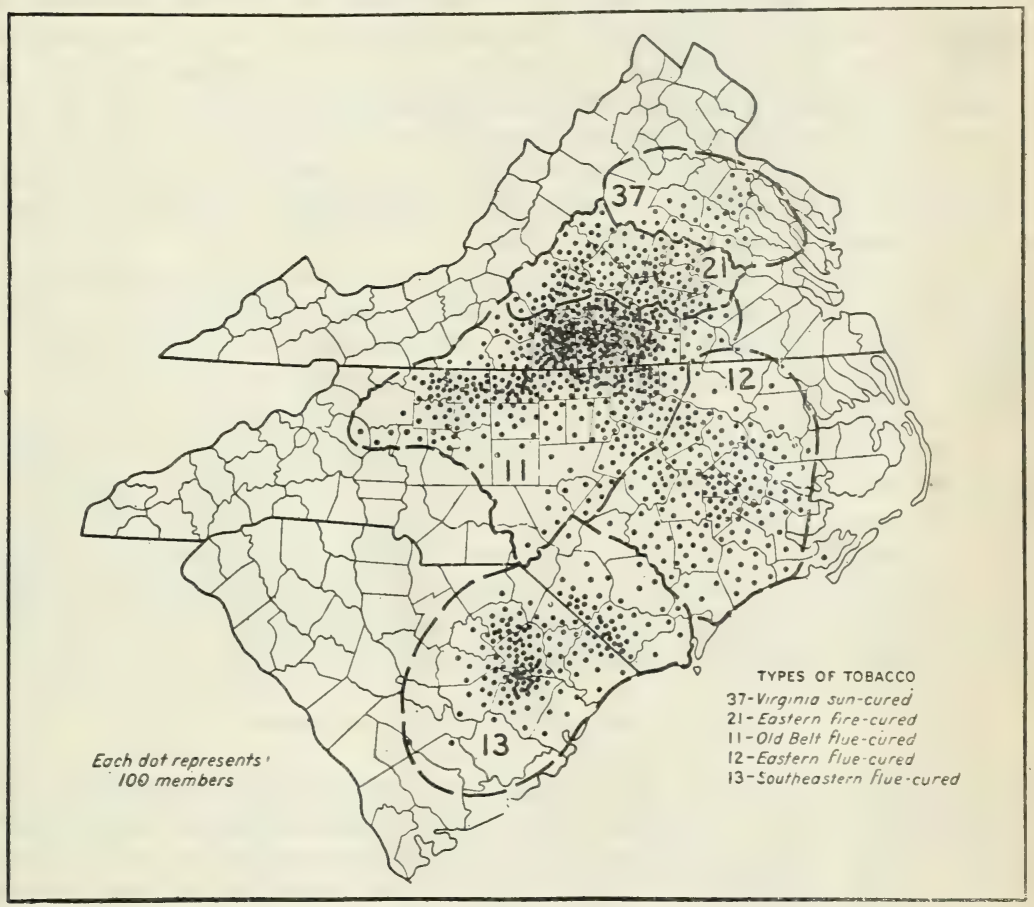

FIGURE 8.-MEMBERs of TOBACCO GROWERS' COOPERATIVE ASSOCIATION AND PRODUCING AREAS, BY TYPES

Of the $\mathbf{9 5 , 9 7 0}$ tobacco growers who joined the Tobacco Growers' Cooperative Marketing Association the greatest concentration was in the Old Belt area of Virginia and North Carolina and in the flue-cured (or dark-fired) area of Virginia.

these contracts in the tri-State area is shown in Figure 8. At no time, however, were there as many active members as there were contracts. During the last two years especially, many members stopped growing tobacco because of dissatisfaction with the association.

\section{DEVELOPMENTS DURING THE MEMBERSHIP CAMPAIGN}

As the association was formed during a period of low prices when growers were anxiously seeking for some means of relief, it was probably inevitable that the growers should see in the proposed 
marketing association an opportunity to arbitrarily control the price of their product, and this attitude was encouraged by the speeches of some of the members of the organization committee, the "selling talks" of solicitors, and in printed matter issued to stimulate organization.

In the fervor, eagerness, and enthusiasm of the membership campaign, the benefits resulting to the members of a tobacco cooperative were described in extraragant terms. It was generally believed that a sufficiently large membership of itself guaranteed the success of the organization. References were too seldom made to the difficulties and limitations of cooperative associations, to the complicated problems of management and merchandising, or to the problem of retaining membership loyalty. Such enthusiasm and optimism was felt by many leaders to be necessary in the formation of such an organization of producers. Unless stimulated in this way, it was believed, the growers might fail to take the necessary steps for group action. The practical difficulty with any organization formed under such utopian and roseate promises and expectations is that a dangerous and harmful reaction will follow.

There can be no doubt but that the spirit and attitude of enthusiasts at this time greatly influenced subsequent developments. During a period of depression any plan of relief may be grasped eagerly without a careful analysis or even reasonable examination of its practicability. Most of the producers seemed to be in a mood to accept any proposal which gave eren reasonable assurance of relief. Farm journals and newspapers contained articles about cooperation, which showed how successful it was in other areas and in handling other commodities. All these factors led many farmers to believe that cooperative marketing of tobacco was bound to succeed and that it would supplant the existing market machinery and insure at least cost of production plus a fair profit to the growers.

ATTITLDE TOWARD THE TOBACCO TRADE

Preceding and during the organization campaign there developed throughout the area an attitude of intense antagonism toward persons and firms engaged in the marketing and manufacture of tobacco. The disastrous decline in the price of tobacco was laid at the door of these agencies. Speeches made and articles written during the campaign intensified this feeling. Many rash and derogatory statements were made regarding the agencies engaged in handling, marketing, and manufacturing tobacco. Belief became widespread that the cooperative association would supplant all agencies then engaged in handling and marketing the crop.

This attitude of many organizers toward existing market organizations during the campaign period was such that the new association in turn incurred the antagonism of the warehousemen and other middlemen. In the beginning, many private dealers were not openly antagonistic to a farmer's organization. When they were informed of the attitude of the organizers, however, and understood that it was the intention of these men to supplant the existing marketing organization, they became aroused and formed organizations to oppose the cooperative movement. The attitude of some of the leaders of the 
association became one not of rendering efficient marketing services to its grower members but rather that of monopolistic control of the market and the setting of a price without full consideration of the factors of demand and supply. This attitude was naturally opposed by the tobacco manufacturing companies in spirit if not by overt acts.

This attitude and feeling was unfortunate for two reasons: It obscured the real purposes and possibilities of cooperative marketing and it aroused the opposition of tobacco dealers and made the progress of the association more difficult. Opposition to the association on the part of these agencies and the part such opposition played in the breakdown of the organization is discussed later.

THE MARKET-CONTROL IDEA

There is evidence that the belief in monopoly control had an influence on the sales policies of the management. The sales policies of the association and operating costs are discussed in following sections. There is also evidence that, in its attitude toward economy in operations, the management was influenced by the prevalent belief in monopoly control. Arguments for economy are weakened when it is believed that excessive costs may be met by merely adding them to the price of the product. Extravagant management in this and other associations no doubt has been encouraged and justified largely by the idea that the tobacco association's control over price would make such extravagances appear of little significance.

A tobacco cooperative association can not rely upon monopolizing the marketing of the tobacco crop for any extended period. High prices bring increased production both within and without the association. In the case of this tobacco association the prices and conditions existing during the time of its operation caused the production of tobacco in Georgia alone to increase from 5,940,000 pounds in 1922 to $39,963,000$ pounds in 1926 . Other large districts are potential tobacco districts, needing only the stimulus of high tobacco prices to cause a shift to tobacco production. Belief and expectation that the Tobacco Growers' Cooperative Association, through a sign-up of over 50 per cent of the crop in its area, would be able to control and dominate the market was doomed to disappointment. The impossibility of the success of such a policy should have been obvious; the harmful effect upon the membership was inevitable.

The purchase and sale of tobacco in comparatively small lots in a large number of independent warehouses under the auction-floor system is inefficient and expensive and open to a great deal of abuse. The manufacturing companies must employ a far larger force of buyers than would be necessary under a cooperative system, in which the tobacco of a large number of members could be pooled and sold in large lots of uniform grade, or by sample. But the cooperative, in order to convince its membership that its method of handling tobacco is more conducive to their interest than is the method of the open warehouses, must render to them better service at the same cost or the same service at less cost. When members learn that cooperative marketing can not hope to control or set prices, their organization will be operated on a more efficient, economical, and businesslike basis, and failures will be fewer.

$76534-29-2$ 
An association should, however, have control over an appreciable portion of the crop produced in a given area. This is necessary for economical operation and in the interests of collective bargaining. The dominant position of the large manufacturing companies in the market makes this essential, especially if it is found difficult to establish friendly relationships between the cooperative organizations and the companies. If any association does not have control over an appreciable portion of the crop, it is in a weak bargaining position.

The attitude and expectations of the members with regard to price are indicated by results of a study of the membership of the association made in 1928. Over 700 members of the association were interviewed, and the answers from 643 questionnaires were tabulated. The number of members visited in each county was approximately in proportion to the number of producers from that county who belonged to the association. Practically every county in the triState area where the association had any appreciable number of members was included in the survey. The interviewed growers were asked, "What was your main reason for joining the association?" 314 replied, "To get better prices." To the question, "What should govern the price which cooperatives try to get for tobacco?" the reply from 108 growers was, "Set prices and hold for these prices"; 172 replied, "Cost of production plus a profit," and only 93 answered, "Supply and demand." As this study was made after the failure of the association, it is evident that the idea of monopoly control was thoroughly ingrained in the membership. This study also showed that comparatively few of the members believed that the association had obtained increased prices for the members. In reply to the question, "What benefits do you think resulted from the operation of the association?" 45 answered, "Better prices at first"; 156 answered, "Raised tobacco prices generally"; 38 replied, "Gave members better prices than if there were no association"; while 350 believed that it raised the prices to nonmembers, but not, presumably, to members.

\section{TYPES OF MEMBERS}

Little discrimination was shown during the membership campaign in the selection of growers who would prove good members of the organization. This resulted, first, in the inclusion of a number of persons who were not tobacco growers and in inflation of the quantity of tobacco which was expected to be available for delivery to the association. It resulted also in the inclusion of many who because of crop mortgages and landlord liens could not deliver their tobacco, and of many more who because of their economic condition or lack of understanding of the movement were a liability rather than an asset.

Not enough consideration was always given to whether a man actually grew tobacco or not. In some sections the aim seemed to be to get as many members as possible, irrespective of their occupation, whether they had ever grown or would ever grow tobacco, or had any financial interest in a tobacco crop. Many nongrowers joined merely out of sympathy for this farmers' movement. This class inflated the membership and gave the officials and management a false basis upon which to judge the strength of the association and to estimate the amount of physical equipment and personnel necessary to handle the expected receipts. 
The 1920 crop was the basis for estimating the members' prospective production. This crop was unusually large, and the association's officials were led to expect more tobacco than would be produced during an average year. Many solicitors estimated the expected member delivery by multiplying the signed acreage by 1,000 poundsan average far too high, especially for flue-cured tobacco. In other instances the owner and tenant were each signed up for the same tobacco, or two or more members of the same family were each given credit for the total acreage. The contracts of some farm owners included the tenant's share of the crop as well as their own, when the tenant was not a member and was privileged to sell his tobacco as he saw fit.

It has often been stated that as a rule the better and more influential farmers did not join the association. This may be true of some farmers who, because of their friendship with warehousemen and buyers, had benefited by higher prices under the auction-floor system of selling, and who would not willingly risk this advantage over their less fortunate neighbors through a change in the system of marketing. Other farmers who produced a high quality of tobacco were satisfied with the prices received for their product and feared the loss of this premium if they joined the association. Many such farmers not only refused to join the association but later used their influence to encourage disloyalty on the part of the members of the association. These farmers failed to realize that by incurring disioyalty among the members of the association they would eventually harm themselves.

On the other hand, included in the membership of the association were very many well-known farmers whose loyalty and support of the association was unfailing in spite of almost certain losses to themselves. In the membership study it was found that the better and more intelligent farmers were the most loyal members, chiefly because they realized the difficulties under which their association was laboring. They often had been securing good prices for their tobacco at auction-floor sales but joined to help their less fortunate neighibors. In signing up tenants and share croppers, little attention was given to the difficulties which would arise in securing delivery of their crops.

\section{THE INTERNAL ORGANIZATION}

\section{DIRECTORS}

The board of directors consisted of 25 members who were elected annually. Of these directors, 22 were members actually residing and growing tobacco in the respective districts from which they were elected. The other three were nominated in writing, one each by the governors of the States of Virginia, North Carolina, and South Carolina. When elected, these three men had full authority as directors, but they represented primarily the interests of the general public in the conduct of the association. For the purpose of electing directors representing the members, the three States were divided into 22 roting districts each of which had approximately the same estimated sign-up of tobacco. Counties within each district, however, were held intact. This division of the area was for the purpose of giving all members equitable and proportionate representa- 
tion. Each year a primary election was held to select one delegate for every million, or majority fraction of a million, pounds of tobacco delivered during the preceding year by the members in that county. The directors were chosen by the delegates at the annual meeting held each May. Prior to the general election at which the directors were elected, the districts were reapportioned if such action was necessary to maintain equality of representation.

The directors, who met monthly in regular meetings, received no compensation for their services as directors, other than their traveling expenses and an allowance of $\$ 10$ per day for time spent at, and while traveling to and from, meetings.

Provision was made for the appointment of a president, two vice presidents, a secretary, a treasurer, and such other officers as the board might deem necessary, and for the necessary compensation of such officers; a general manager could also be appointed at the discretion of the board of directors.

The board of directors had the power to appoint an executive committee of five from among its members. The president and the two vice presidents were ex officio members, and two other members, one of whom could be a public director, were chosen. Two advisory members could be appointed on the executive committee. The directors could, at their discretion, provide reasonable compensation for members of the executive committee of the board, plus all expenses.

\section{DEPARTMENTS}

Besides the administrative office at Richmond, Va., there were four major departments - the warehouse and the leaf departments located at Richmond, Va., and the field service and the legal departments located at Raleigh, N. C. (Fig. 9.)

The warehouse department was placed under the control of a director of warehouses, who was assisted by an assistant director and several district directors. The function of this department was to take care of the physical handling of the tobacco. The acquisition of warehouse property through purchase or lease and the collection of liquidated damages were among its tasks. It was in charge of the tobacco from the time it was received until it was disposed of by the leaf department through sale.

The leaf department was divided into two subdepartments, the dark leaf and the bright leaf, each under a separate and independent general manager, who was responsible directly to the executive committee. Upon the death of the general manager of the dark-leaf department, both these departments came under the direction of the general manager of the bright-leaf department. These general managers were each assisted by one or more assistant managers, and by a staff of graders, supervising graders, and factory inspectors.

The functions of this department were to grade all tobacco as it was delivered by members, and later to sell the tobacco in the green or redried state. The negotiation of contracts for the redrying of tobacco was placed in the hands of the general managers of the two subdivisions of the leaf department. The relationship between the leaf and warehouse departments was necessarily very close. Warehouse officials were responsible for the acceptance, weighing, and advance payments on tobacco delivered by members, whereas leaf-de- 
partment officials were responsible for the grading of such tobacco as it was delivered. At practically every receiving point there were employees of both departments. Later, in some localities, the duties of grader and warehouseman were combined to reduce expenses.

The personnel of the field-service department comprised its director, five district field men, assistants, and clerical help. The association's house organ, the Tri-State Grower, the weekly News Letter, and the editor of these publications also were in this department. The duties of this department were to assist in organizing local units, to conduct and address local and general meetings, to solicit new members, to obtain the delivery of the crop, to keep the members acquainted with the operations of the association, to develop in them the spirit of the cooperative movement, and in general to keep up the

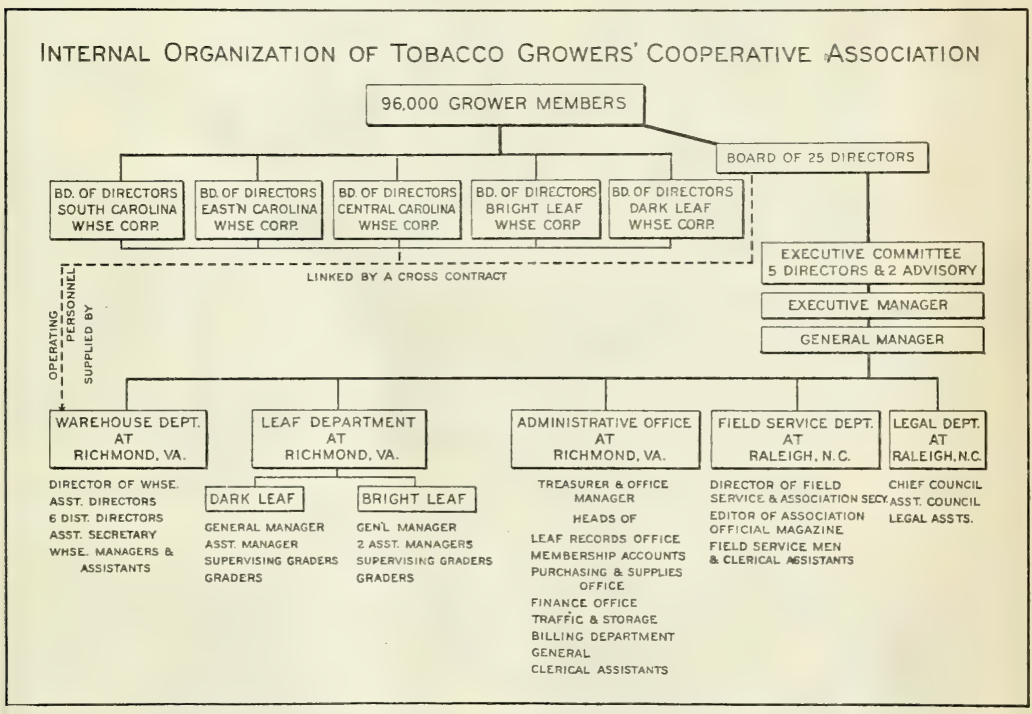

\section{Figure 9.-Internal Organization of Tobacco Growers' Cooperative ASSOCIATION}

Besides the administrative office at Richmond, Va., there were four major departmentsthe warehouse and leaf departments at Richmond, Va., and the field service and legal departments located at Raleigh, N. C. Five subsidiary warehousing corporations were linked to the association by cross contracts.

morale of the members and to promote the welfare of the association among the farmers.

The legal department consisted of a chief counsel, an assistant counsel, and local legal assistants. Their duties were to bring suits for liquidated damages or injunction against disloyal members and to protect, advise, and help the association in all legal matters.

\section{SUBSIDIARY WAREHOUSING CORPORATIONS}

The association made provision for the establishment of warehousing or other corporations where and when necessary for the handling of tobacco delivered to the association. Five warehousing corporations were established; two, the Bright Leaf Corporation and the 
Dark Leaf Corporation, in Virginia ; two, the Central Carolina Corporation and the Eastern Carolina Corporation, in North Carolina; and one, the South Carolina Warehousing Corporation, in South Carolina. The areas covered by each warehouse corporation corresponded roughly to the tobacco pool areas. They did not exactly coincide because the area of the pools depended upon the type of tobacco grown, whereas the warehouse corporations were operated only in the State in which they were incorporated. (Fig. 10.)

According to the original plan these corporations were to be financed by issues of common and preferred stock. The par value of

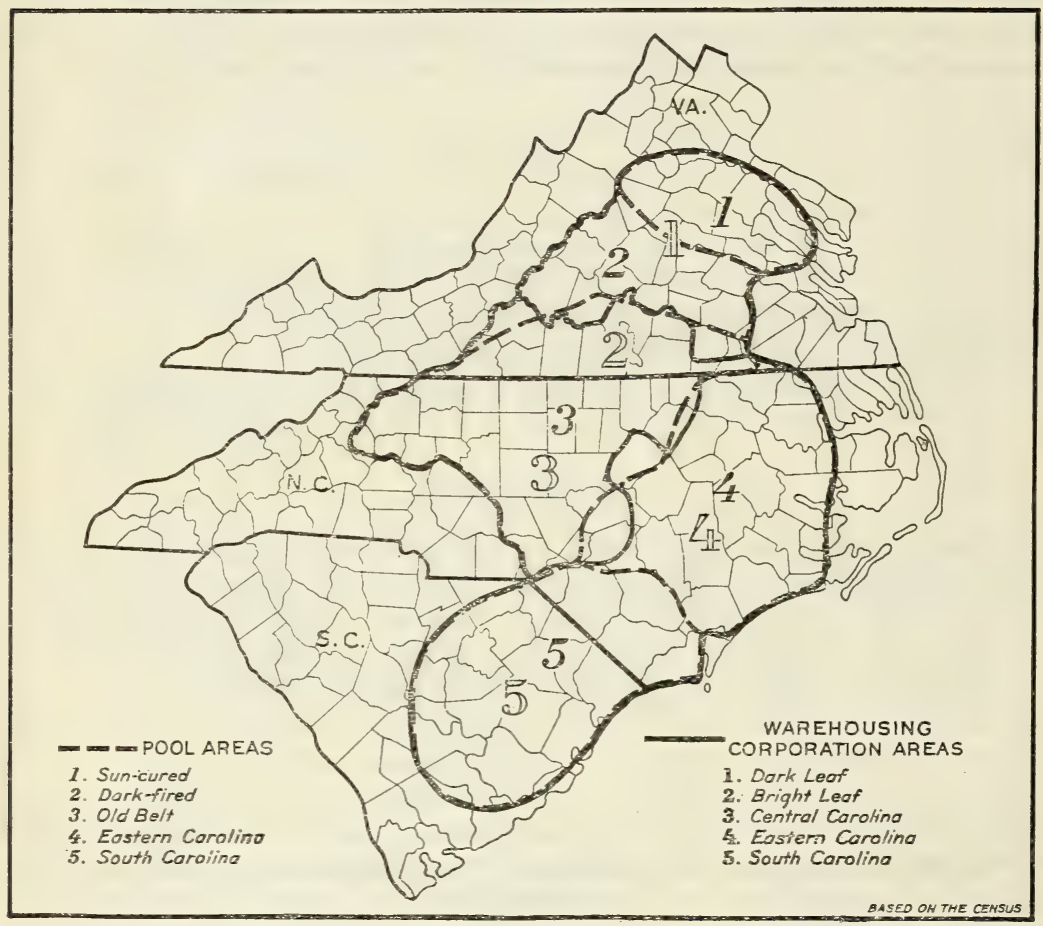

Figure 10.-Pool and Warehousing Corporation areas of the association

The area of the cooperative association was divided into five pool areas on the basis of type of tobacco and into five warehousing corporations, which while similar to the pool areas in location did not coincide.

the original issue of preferred stock for each district corporation was not to exceed 1 cent for each pound of tobacco of the 1920 crop produced by the membership of that district. Owing to difficulties of financing it was necessary to depart radically from the plan presented in the original association agreement.

\section{TYPE OF ORGANIZATION}

In attempting to organize a highly centralized complex form of cooperative organization of the size of the Tobacco Growers' Cooperative Association within a comparatively short period of time and without any previous experience as a guide, it is almost impossible to insure from 
the beginning a well coordinated and efficient internal administration. Being organized in three States and handling five more or less different varieties of tobacco made the problems of management still more complex and difficult. ${ }^{7}$ The separation of the field-service department in Raleigh, N. C., and the administrative office in Richmond, Va., resulted in lack of contact and sympathetic understanding of the problems connected with the maintenance of membership morale. The administrative office at Richmond was on the edge of the association area instead of being centrally located. The association was so large, so far removed, and so indirect in its relations to its members that it was cumbersome and failed to respond to their wishes and needs. The organization of five separate pools and warehousing corporations was a most extravagant and complicated set-up.

Failure of the association to obtain delivery in eastern North Carolina from the beginning raised the question of the advisability of having one association to handle so many different types of tobacco and covering such a wide and diverse territory. The association was put to a great deal of expense in purchasing warehouses in this territory and in employing warehouse and field-service officials to try to build up the morale. It would seem that the association would have been a great deal more successful without this territory. In fact, it would probably have been better had five different associations been formed, with a federated organization to which could have been delegated such functions as were of common interest. Under such a plan the failure of any one district would not have had such an adverse effect on the other districts as when all districts were closely united under one association.

\section{MEMBERS' RESPONSIBILITY FOR FAILURE OF THE ASSOCIATION}

A very important factor contributing to the failure of the Tobacco Growers' Cooperative Association was the lack of support and assistance given to it by its members. This lack of support and assistance was felt by the association in two ways: (1) In the failure on the part of many to deliver any or all of their tobacco to the association, and (2) in the failure, either through inability, inertia, or unwillingness, of the majority of the members to take an active and helpful interest in the operation and administration of their association.

Much of this lack of member support and assistance was involuntary; part of it was voluntary. In many instances the members were not in a position to deliver their tobacco to the association under the policies and conditions under which it was operated and were not fitted to be helpful in aiding it in its problems and difficulties. Other members who, through their financial conditions, training, business ability, or experience, could have assisted the organization through delivery of their pledged tobacco and through acts of loyalty, advice, and constructive support, either became passively inactive and disloyal or became actively injurious through their acts and speech in respect to the association. The following pages show in more detail to what extent the members were responsible for the failure of the cooperative.

\footnotetext{
${ }^{7}$ Figure 8, page 15.
} 


\section{CONDITIONS OF FARM POPULATION IN THE TRI-STATE AREA}

An appreciation of some of the more intangible aspects of the problem is essential to a full understanding of all of the causes of the failure of the Tobacco Growers' Cooperative Association and of the difficulties in the way to the successful cooperative marketing of tobacco or other products in Virginia, North Carolina, and South Carolina. There are conditions in the tri-State area which undoubtedly contributed to the failure of the organization through affecting the membership attitudes.

The small size of many farms in these three States and the small acreage in crops tend to give their owners low incomes. Over half of the farms have less than 50 acres, and over three-fourths have less than 100 acres. Because of the nature of the soil, topography, and the lack of cleared land much of the land in farms is not crop land. According to the 1925 Census of Agriculture (10, pt. 2, County Tables IV) only two-fifths of the total land in farms in eight of the more important tobacco-producing counties in the three States was crop land. ${ }^{8}$ For the same counties 6.9 per cent of the total land in farms and 16.9 per cent of crop land was in tobacco.

The presence of both large and small farmers creates a condition which hinders the development of a real cooperative spirit. The large farmer and the land-owning farmer often have other sources of income, such as interests in warehouses, stores, fertilizer plants, and sawmills. This makes them less dependent upon their income from tobacco than are the small farmers, who may be totally dependent upon a few cash crops for their income. Although the more independent farmer with several sources of income should be the better cooperator because of his ability to live up to a marketing agreement better, there is often less need and desire on his part for him to join an association. As a result, these large growers, unless public spirited, may hesitate or refuse to join a cooperative-marketing enterprise, and because of the large volume of the product which they control they may influence greatly the portion of that product that will be sold through the association.

Some of the large and influential landowners personally attended to the cultivation of only a small portion of their estates, some gave no attention, and comparatively few of them live on the farms. Some of those who have remained on their estates personally control and supervise the operations of their tenants and work only a small portion themselves. During the last generation the social, educational, and economic advantages to be found in the towns and cities have caused a migration of many of these landowners and their children to the city, giving rise to absentee landlordism and to some of the evils thereof. These landlords exercise only a loose supervision over their estates, having lost their interest in farming, and have become more or less out of sympathy with the tenants.

This absentee landlordism was increased during and after the World War by the acquisition of bankrupt estates by business and professional men, such as bankers, doctors, lawyers, and business men, who maintain only an imperfect and loose contact with the tenants.

- Pittsylvania and Halifax Countles, Va.; Stokes, Granville, Pitt, and Greene Counties, N. C. ; and Darlington and Florence Counties, S. C. 


\section{TENANCY}

On the basis of the 1925 census of agriculture, Figure 11 shows the percentage of tenancy by counties in the three States of Virginia, North Carolina, and South Carolina. The percentage of tenancy is greater in North Carolina than in Virginia, and greater in South Carolina than in North Carolina. The districts of high tenancy are districts in which a larger proportion of the farmers are colored (fig. 12 ) and districts which depend largely upon one or more cash crops.

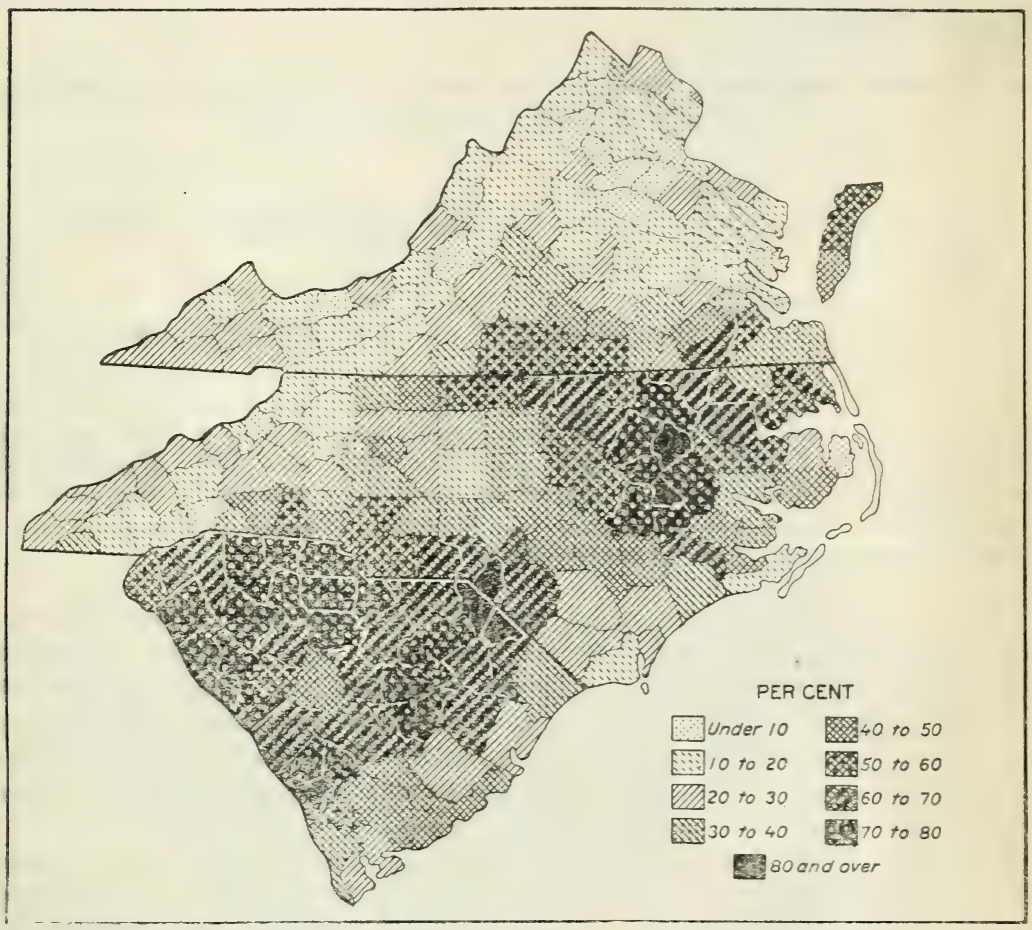

Figure 11.-The Percentages of Tenancy by Counties in Virginia, North CAROLINA, AND SOUTH CAROLINA, 1925

The percentage of tenancy tends to be highest in the counties where tobacco and cotton are the chief crops.

The percentage of tenancy is high in those counties in which tobacco or cotton is grown. For the States as a whole the percentages are as follows: Virginia, 25.2 per cent; North Carolina, 45.2 per cent; South Carolina, 65.1 per cent. In some counties in which both cotton and tobacco are grown the percentage of tenancy exceeds 80 per cent. Not only are the percentages of tenancy high but the average percentage of tenants who are croppers ranges from 32 per cent in Virginia to 41.2 per cent in South Carolina. In the important tobacco and cotton producing counties these percentages are even higher than for the entire States.

The situation is further aggravated by the presence of the race complication. Figure 12 shows graphically the percentages of farm- 
ers that are colored in the three States by counties for 1925. Table 3 gives in detail the percentages of white and colored farmers, the percentages of tenants, croppers, etc., who are white and colored. From one-fourth of the farmers in Virginia to over a half in South Carolina are colored. For the tobacco section alone the relative number of colored farmers is larger. Tenancy among colored farmers is more frequent than among the whites, the percentage running as high as 80 in South Carolina. In Virginia 65.4 per cent of the tenants are whites and 34.6 per cent colored; in South Carolina these percentages are reversed, being 35.8 per cent white tenants and 64.2 per cent colored.

TABLE 3.-Race and tenure status of the farmers of Virginia, North Carolina, and South Carolina, January 1, 1925

\begin{tabular}{|c|c|c|c|c|c|c|c|c|c|c|c|c|}
\hline \multirow{3}{*}{ State } & \multicolumn{5}{|c|}{ All farmers who are- } & \multirow{3}{*}{$\begin{array}{c}\text { White } \\
\text { farm- } \\
\text { ers } \\
\text { who } \\
\text { are } \\
\text { ten- } \\
\text { ants }\end{array}$} & \multirow{3}{*}{\begin{tabular}{|c} 
Col- \\
ored \\
farm- \\
ers \\
who \\
are \\
ten- \\
ants
\end{tabular}} & \multirow{2}{*}{\multicolumn{2}{|c|}{$\underset{\text { race }}{\text { Tenants by }}$}} & \multirow{2}{*}{\multicolumn{2}{|c|}{$\underset{\text { race }}{\text { Croppers by }}$}} & \multirow{3}{*}{$\begin{array}{l}\text { Ten- } \\
\text { ants } \\
\text { who } \\
\text { are } \\
\text { crop- } \\
\text { pers }\end{array}$} \\
\hline & \multirow{2}{*}{ White } & \multirow{2}{*}{$\begin{array}{l}\text { Col- } \\
\text { ored }\end{array}$} & \multicolumn{3}{|c|}{ Tenants } & & & & & & & \\
\hline & & & Total & 1 ; White & $\begin{array}{l}\text { Col- } \\
\text { ored }\end{array}$ & & & White & $\begin{array}{l}\text { Col- } \\
\text { ored }\end{array}$ & White & $\begin{array}{l}\text { Col- } \\
\text { ored }\end{array}$ & \\
\hline $\begin{array}{l}\text { Virginia } \\
\text { North Carolina-...... } \\
\text { South Carolina........ }\end{array}$ & $\begin{array}{l}\text { Per } \\
\text { cent } \\
74.1 \\
71.4 \\
47.6\end{array}$ & \begin{tabular}{|l} 
Per \\
cent \\
25.9 \\
28.6 \\
52.4
\end{tabular} & $\begin{array}{l}\text { Per } \\
\text { cent } \\
25.2 \\
45.2 \\
65.1\end{array}$ & $\begin{array}{l}\text { Per } \\
\text { cent } \\
16.5 \\
24.5 \\
23.3\end{array}$ & $\begin{array}{r}\text { Per } \\
\text { cent } \\
8.7 \\
20.7 \\
41.8\end{array}$ & $\begin{array}{c}\text { Per } \\
\text { cent } \\
22.3 \\
34.3 \\
49.0\end{array}$ & $\begin{array}{l}\text { Per } \\
\text { cent } \\
33.8 \\
72.7 \\
79.7\end{array}$ & $\begin{array}{l}\text { Per } \\
\text { cent } \\
65.4 \\
54.1 \\
35.8\end{array}$ & \begin{tabular}{|c|} 
Per \\
cent \\
34.6 \\
45.9 \\
64.2
\end{tabular} & $\begin{array}{c}\text { Per } \\
\text { cent } \\
55.4 \\
41.9 \\
30.2\end{array}$ & \begin{tabular}{|c} 
Per \\
cent \\
44.6 \\
58.1 \\
69.8
\end{tabular} & $\begin{array}{c}\text { Per } \\
\text { cent } \\
32.0 \\
40.9 \\
41.2\end{array}$ \\
\hline
\end{tabular}

Census of Agriculture, 1925 (10, pt. 2, County Tables I).

The percentages of the croppers who are colored in the different States are Virginia, 44.6; North Carolina, 58.1; South Carolina, 69.8. The croppers are the more impecunious class of tenants and are almost wholly cotton and tobacco growers. They tend to change their residence more frequently than do owners or other tenants, and they own very little property. Tenants and croppers usually have very low standards of living.

As compared with that in some other sections of the United States the value of land in these three States is low. The soil requires large quantities of expensive commercial fertilizer to be profitably productive. Table 4 gives the average value of farm property per farm according to the 1925 census of agriculture.

Tobacco farms do not require a high capitalization of land and equipment. The land is of fairly low valuation, and the buildings are not expensive. The tobacco barns are usually made chiefly of native timber of low local value. Little livestock or machinery is needed, as tobacco requires much man labor and but little horse labor.

Despite the comparatively low capitalization of land and buildings, it seems difficult for the cropper or tenant to climb the agricultural ladder to ownership of his farm. The son of a landless farmer usually remains landless. This is more true among the negroes than among the whites $(\%, p .36)$. 
TABLE 4.-Value of farm property per farm and of land and of buildings per acre in Virginia, North Carolina, and South Carolina, 1925

\begin{tabular}{|c|c|c|c|}
\hline Kind of property & Virginia & $\begin{array}{l}\text { North } \\
\text { Carolina }\end{array}$ & $\begin{array}{l}\text { South } \\
\text { Carolina }\end{array}$ \\
\hline T and & Dollars & Dollars & Dollars \\
\hline Buildings.. & $\begin{array}{l}3,100.69 \\
1,477.05\end{array}$ & $2,421.40$ & 639.75 \\
\hline Livestock & 1, 374.91 & 273.57 & 245.17 \\
\hline Implements and machinery, by tenure: & & & \\
\hline Tenants & $\begin{array}{r}131.76 \\
83.46\end{array}$ & 98.91 & $\begin{array}{l}69.65 \\
48.87\end{array}$ \\
\hline 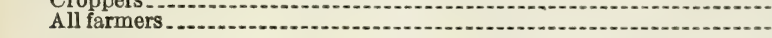 & $\begin{array}{r}83.40 \\
206.59\end{array}$ & 163.80 & 133.73 \\
\hline All farm property. & $5,159.24$ & $3,703.98$ & $3,027.63$ \\
\hline $\begin{array}{l}\text { Land per acre } \\
\text { Buildings per acre }\end{array}$ & $\begin{array}{l}34.90 \\
16.63\end{array}$ & $\begin{array}{l}36.92 \\
12.88\end{array}$ & $\begin{array}{l}32.62 \\
10.39\end{array}$ \\
\hline
\end{tabular}

Census of Agriculture, 1925 (10).

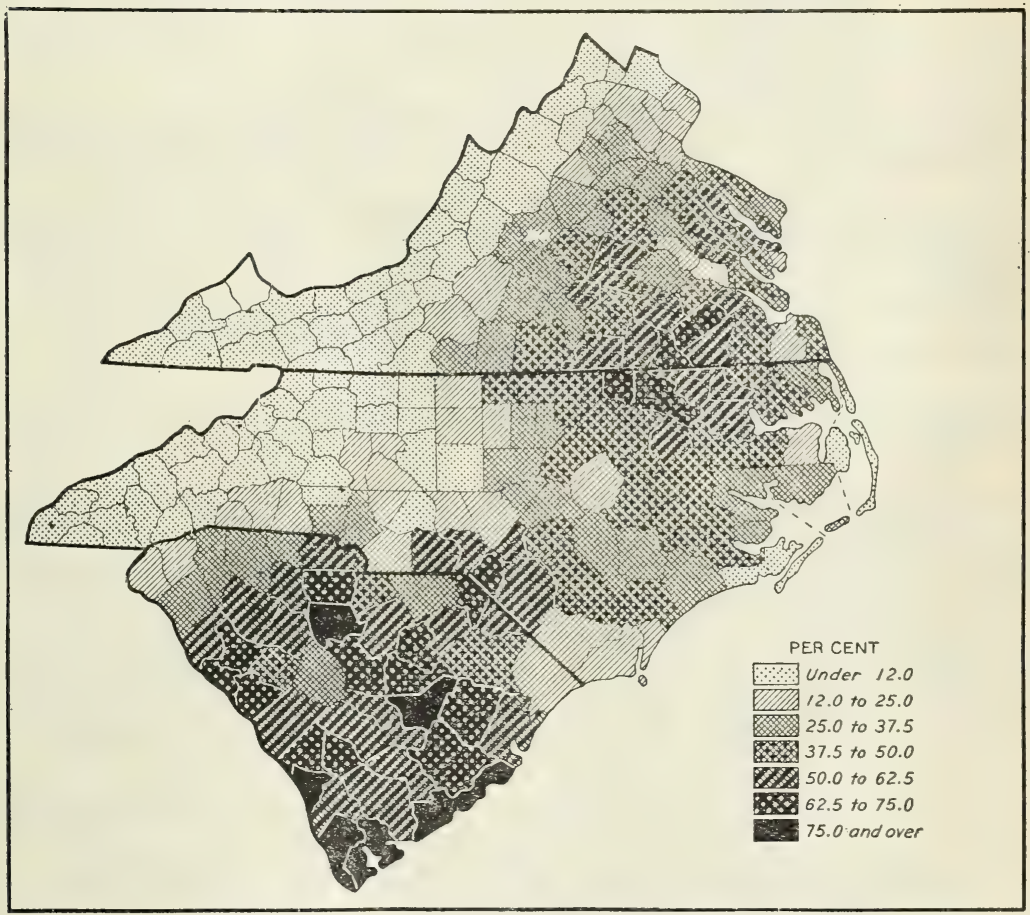

Figure 12.-PERCentage of Colored Farmers, 1924, in Virginia, North CAROLINA, AND SOUTH CAROLINA

The ratio of colored farmers to all farmers tends to be largest in the counties where the tenancy is high and where the farmers depend largely upon one or two cash crops.

\section{FARM INCOME}

In the important tobacco-growing counties of the tri-State area the farm income is usually low as compared with the farm incomes in many other parts of the United States. Although 1922 was a favorable year for the Virginia tobacco growers, on 138 dark-tobacco farms in Appomattox County during that year the average operator earn- 
ing was only $\$ 735$. On 150 farms in Pittsylvania County that grow bright tobacco it was $\$ 1,231$ (14, pp. 18-19). A study of 300 farmers in South Carolina and 420 in North Carolina, in 1926, showed that 48 per cent of those farmers in South Carolina and 33 per cent in North Carolina received farm receipts averaging less than $\$ 270$ a year. (Table 5.) In South Carolina 83 per cent of the 300 received an average of $\$ 512 ; 77$ per cent of the 420 North Carolina farmers received farm receipts averaging $\$ 657 .^{\circ}$

TABLE 5.-Receipts, credit used, and ratio of credit to receipts of North Carolina and South Carolina farmers ${ }^{1}$

\begin{tabular}{|c|c|c|c|c|c|c|c|c|c|c|c|c|c|c|c|}
\hline \multirow[b]{2}{*}{ State and receipts } & \multicolumn{6}{|c|}{ Farmers } & \multicolumn{3}{|c|}{$\begin{array}{l}\text { Average } \\
\text { receipts }\end{array}$} & \multicolumn{3}{|c|}{$\begin{array}{l}\text { A verage } \\
\text { credit }\end{array}$} & \multicolumn{3}{|c|}{$\begin{array}{l}\text { Ratio of credit } \\
\text { to receipts }\end{array}$} \\
\hline & \multicolumn{2}{|c|}{ 造 } & \multicolumn{2}{|c|}{ 营 } & \multicolumn{2}{|c|}{ 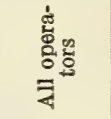 } & 造 & 莺 & 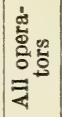 & 䞤 & 莺 & 离 & 总 & 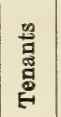 & 密。 \\
\hline $\begin{array}{l}\text { North Carolina: } \\
\$ 0-\$ 500 \\
\quad \$ 501-\$ 1,500 \\
\$ 1,501 \text { and over... }\end{array}$ & $\begin{array}{r}\text { No. } \\
135 \\
171 \\
91 \\
\end{array}$ & $\begin{array}{r}\text { Per } \\
\text { cent } \\
34 \\
43 \\
23 \\
\end{array}$ & $\begin{array}{r}\text { No. } \\
4 \\
14 \\
5 \\
\end{array}$ & $\begin{array}{r}\text { Per } \\
\text { cent } \\
17 \\
61 \\
22 \\
\end{array}$ & $\begin{array}{r}\text { No. } \\
139 \\
185 \\
96 \\
\end{array}$ & $\begin{array}{r}\text { Per } \\
\text { cent } \\
33 \\
44 \\
23 \\
\end{array}$ & $\begin{array}{r}\text { Dol. } \\
265 \\
950 \\
1,930 \\
\end{array}$ & $\begin{array}{r}\text { Dol. } \\
305 \\
926 \\
4,000 \\
\end{array}$ & $\begin{array}{r}\text { Dol. } \\
266 \\
950 \\
2,980 \\
\end{array}$ & $\begin{array}{r}\text { Dol. } \\
80 \\
230 \\
840 \\
\end{array}$ & $\begin{array}{r}\text { Dol. } \\
135 \\
340 \\
706 \\
\end{array}$ & $\begin{array}{r}\text { Dol. } \\
81 \\
239 \\
832 \\
\end{array}$ & $\begin{array}{r}0.30 \\
.24 \\
.44 \\
\end{array}$ & $\begin{array}{r}0.44 \\
.37 \\
.18 \\
\end{array}$ & $\begin{array}{r}0.30 \\
.25 \\
.28 \\
\end{array}$ \\
\hline Total. & 397 & 100 & 23 & 100 & 420 & 100 & 942 & 1,490 & 1,190 & 318 & 385 & 322 & .34 & .26 & .27 \\
\hline $\begin{array}{l}\text { South Carolina: } \\
\$ 0-\$ 500 \\
\$ 501-\$ 1,500 \\
\$ 1,501 \text { and over.... }\end{array}$ & $\begin{array}{r}108 \\
93 \\
47\end{array}$ & $\begin{array}{l}43 \\
38 \\
19\end{array}$ & $\begin{array}{r}35 \\
13 \\
4\end{array}$ & $\begin{array}{r}67 \\
25 \\
8\end{array}$ & $\begin{array}{r}143 \\
106 \\
51\end{array}$ & $\begin{array}{l}48 \\
35 \\
17\end{array}$ & $\begin{array}{r}264 \\
844 \\
3,250\end{array}$ & $\begin{array}{r}278 \\
830 \\
1,820\end{array}$ & $\begin{array}{r}268 \\
842 \\
3,140\end{array}$ & $\begin{array}{r}187 \\
513 \\
1,705\end{array}$ & $\begin{array}{l}284 \\
586 \\
622\end{array}$ & $\begin{array}{r}210 \\
524 \\
1,620\end{array}$ & $\begin{array}{l}.71 \\
.61 \\
.52\end{array}$ & \begin{tabular}{r|}
1.02 \\
.71 \\
.34 \\
\end{tabular} & \begin{tabular}{|l}
.78 \\
.62 \\
.52 \\
\end{tabular} \\
\hline Total & 248 & 100 & 52 & 100 & 300 & 100 & 1,050 & 536 & 957 & 597 & 389 & 561 & .57 & .73 & .59 \\
\hline
\end{tabular}

${ }^{1}$ Summary of reports secured in credit study made by the Agricultural Finance Division of the United States Department of Agriculture, 1927.

Not only is the farm income relatively low but it is less dependable because of the high degree of dependence upon one or two cash crops. Tobacco only in some parts, and cotton and tobacco in other parts of the tri-State area are the chief cash crops, although they occupy only about one-fourth of the total crop acreage. According to the 1928 Report of the Tax Commission of North Carolina, 96.6 per cent of all crop receipts and 67.4 per cent of all gross receipts in Person County, and 74.6 per cent of all crop receipts and 59.2 per cent of all farm recipts in the Lenoir area were from tobacco alone. In Appomattox and Pittsylvania Counties, Va., growing dark tobacco and bright tobacco, respectively, the percentages of gross income from cash crops were 61.9 per cent and 84 per cent of the total. In Appomattox County, tobacco gave 49 per cent of the gross farm income and in Pittsylvania 76 per cent $(14, p .15)$.

This lack of diversification is generally conceded to be largely responsible for the condition of the tobacco and cotton growers. It results in the growing of too few food crops, soil-improvement crops, and animals except for work purposes. Dependence upon a few nonfood cash crops, which are usually sold soon after harvesting, does not tend to create thrift and farm prosperity. The lack of diversification of crops in this area is due, among other causes, to the preva-

' Data from Division of Agricultural Finance, Bureau of Agricultural Economics. 
lence of the tenant system, to relatively infertile soil, to occasional profitable cotton and tobacco crops, to custom, to lack of experience with and capital for other farm enterprises, and to the lack of markets or marketing facilities for other products.

Many of the growers, in addition to having low farm incomes for only one or two cash crops and having little or no other salable articles or source of income, produce an insufficient quantity of their own foods, such as poultry products, meats, milk, fruits, and vegetables, as well as of feeds and fuel. A survey of 353 farms in North Carolina and South Carolina made by the Bureau of Agricultural Economics shows that in 1926 those of owners were 88.5 per cent self-sufficient and those of tenants 77.9 per cent self-sufficient. In finding the degree of self-sufficiency, the ratio of the value of food, feed, and fuel actually produced on the farm, to that which could be reasonably expected to be produced there, was used. ${ }^{10}$ The farms are often luarren of improvements or of livestock. Many districts have less than an average of one cow per farm. There is an average of about one dairy cow per farm for the entire three States and about one and a half work animals. Table 6 shows the small number of animals per farm in 1925 in some of the important tobacco-producing counties in the three States.

TABLE 6.-Average number of animals per farm in important tobacco-producing counties of Virginia, North Carolina, and south Carolina, and averages for the three States, January 1,1925

\begin{tabular}{|c|c|c|c|c|c|c|c|}
\hline State and county & Horses & Mules & Cattle & $\begin{array}{l}\text { Dairy } \\
\text { cows }\end{array}$ & Swine & Chickens & Sheep \\
\hline $\begin{array}{l}\text { Virginia } \\
\text { Appomattox } \\
\text { Caroline } \\
\text { Mecklenburg } \\
\text { Pittsylvania } \\
\text { North Carolina } \\
\text { Greene } \\
\text { Guilford } \\
\text { Pitt } \\
\text { Robeson } \\
\text { Stokes. } \\
\text { South Carolina } \\
\text { Florence. } \\
\text { Horry }\end{array}$ & $\begin{array}{l}1.34 \\
1.31 \\
.98 \\
.64 \\
.67 \\
.46 \\
.20 \\
.81 \\
.25 \\
.20 \\
.36 \\
.28 \\
.34 \\
.15\end{array}$ & $\begin{array}{r}0.53 \\
.38 \\
1.03 \\
1.00 \\
.76 \\
.99 \\
1.27 \\
.80 \\
1.13 \\
1.29 \\
1.96 \\
1.15 \\
1.16 \\
1.05\end{array}$ & $\begin{array}{r}4.16 \\
2.14 \\
2.14 \\
1.84 \\
1.50 \\
1.90 \\
.62 \\
2.79 \\
.54 \\
.76 \\
1.54 \\
1.97 \\
1.87 \\
1.02\end{array}$ & $\begin{array}{r}1.51 \\
1.23 \\
1.50 \\
.94 \\
1.00 \\
.89 \\
.24 \\
1.93 \\
.19 \\
.44 \\
.73 \\
.85 \\
.65 \\
.36\end{array}$ & $\begin{array}{l}\text { 3. } 01 \\
1.92 \\
2.10 \\
2.00 \\
1.20 \\
3.07 \\
4.27 \\
2.18 \\
3.84 \\
3.50 \\
1.27 \\
3.09 \\
4.27 \\
2.96\end{array}$ & $\begin{array}{l}47.60 \\
34.50 \\
38.57 \\
38.11 \\
26.80 \\
30.19 \\
28.70 \\
40.30 \\
34.80 \\
24.60 \\
29.60 \\
24.50 \\
28.90 \\
25.40\end{array}$ & $\begin{array}{l}1.81 \\
.02 \\
.19 \\
.22 \\
.04 \\
.23 \\
.02 \\
.06 \\
.05 \\
.01 \\
.01 \\
.08 \\
.02 \\
.08\end{array}$ \\
\hline Weighted average 3 States.. & .68 & .89 & 2.57 & 1.06 & 3.06 & 33.87 & .66 \\
\hline
\end{tabular}

Data from Census of Agriculture, 1925 (10).

It is difficult for the tobacco farmer to diversify his crops or even to change his type of tobacco. The soil in these three States on which tobacco is grown is usually not well suited to. growing other crops or other types of tobacco profitably. The lack of capital and experience tends to prevent the tobacco planters from going into livestock raising. Market facilities for other than tobacco and cotton crops are absent or inadequate. The cultivation and curing of tobacco requires skill and judgment acquired through years of experi-

${ }^{10}$ Division of Agricultural Finance, Bureau of Agricultural Economics. In arriving at the degree of self-sufficiency the ratio of the value produced on the farm to the value consumed of the following foods, feed, and fuel was calculated : Foods-beef, veal, pork, bacon, mutton, chickens, eggs, vegetables, fruit, milk, butter, and sirup : feeds-corn, hay, oats, and other feeds for cows, pigs, etc.; and all fuel. 
ence and passed on from generation to generation. Usually the susceptibility of the tobacco plant to the influence of soil and climate retards or even prohibits the cultivation of a type of tobacco in a given locality different from the type already grown, and hinders a given locality in adjusting the type to the changing requirements of the market.

Low farm incomes have a tendency to cause many people to leave the farm, especially the young people. From 1910 to 1925 the farm population of the three States decreased 105,045. For the 5-year period 1920 to 1925 the decrease was 301,409 , or over 8 per cent. Low farm incomes make farm life unattractive and hinder progress and improvement. As a final result of low farm incomes the type of farmers and standards of living of the farming population tend to be constantly lowered as compared to that of the urban population.

\section{FARM CREDIT}

With one or two seasonal cash crops as the chief and often sole source of income, with a high percentage of tenancy, need of considerable capital to grow and market the crops, and the lack of diversification on most farms, a large demand for credit facilities is created. In many localities the farmers obtain their sole cash income during about two months of the year. Most of this goes to pay the debts of the current year. Credit from some source is then needed after the first of the succeeding year to carry the farmer over until the next crop is marketed, for they must have fertilizer, household supplies, clothing, and other necessities. In a large proportion of the cases a crop lien or mortgage is given to the local merchant (the so-called time merchant), banker, or fertilizer man.

The amount of credit used as compared to the farm receipts in 1926 is shown in Table 5. In North Carolina the average amount of credit used was over a fourth of the receipts. In South Carolina the credit was 57 per cent of the receipts for the owners and 73 per cent for the tenants. The percentage of credit is higher for the lowerincome groups, averaging over 100 per cent of the farm receipts for the South Carolina tenants who received an annual income of less than $\$ 500 .^{11}$ The tenants tending to be in the lower-income groups usually use a relatively greater proportion of credit than do the landowners.

In a study of social and economic conditions in North Carolina $(\%, p .28-31)$ it was found that in Edgecombe County from 79 per cent to 100 per cent of the farmers, depending upon tenure and race, used short-term and intermediate credit. Over half of this credit was used for living; the remainder was used for fertilizer, feed, seed, and tools. Practically all of this credit was from merchants and landlords, except in the case of owners or landlords who made some use of bank credit. Over half of the white tenants and croppers and practically all of the colored tenants and croppers produced crops under crop lien or landlord credit. A smaller percentage of operatorlandlords and owner-operators had liens against their crops. In most cases the holder of a crop lien exercises certain rights in regard

w Information from Division of Agricultural F'inance, Bureau of Agricultural Economics. 
to the sale of the crop. This is especially true of the landless producers who have no security other than the crop.

A survey of 361 farmers in the piedmont and coastal districts of North Carolina and South Carolina shows that of this number 73 per cent of the owners and 87 per cent of the tenants used short-term credit in 1926, and that the credit given on the two storable cash crops (cotton and tobacco) was 39.3 per cent of the value of these crops for the owners and 44.1 per cent for the tenants. ${ }^{12}$ In other words, over three-fourths of the tobacco and cotton farmers reporting borrowed about 40 per cent of the value of their cash crop on shorttime credit for living requirements and to enable them to produce and market their crops of the current year.

A feature of considerable importance is the relationship between the farming population and the time merchant. 'The credit situation in the Southern States has frequently been described by writers and has been roundly condemned by all. The time merchants have been severely criticized, but it is doubtful whether they as a class are as antagonistic to the interests of the farming population as they are often depicted. They are probably just as much a product of the prevailing conditions as are the tenant farmers.

It is admitted that the crop lien is the curse of the southern farmer, but it is extremely doubtful whether it has benefited either the time merchant or the banker. In many areas of the South, because they obtain their cash income during about two months of the year when their crops are sold, the farmers depend upon the time or supply merchants for household or farm requisites during six or eight months of the year. The economic function of the time merchant is thus to supply the farmers (usually tenants and croppers, but frequently owners as well) with goods on credit. These goods are usually paid for as soon as the annual cash crop is sold. If the season is a poor one, owing to adverse weather or other conditions, the time merchant frequently has to bear very heavy losses, which even the high rate of interest charged on goods sold on credit fails to cover. In a recent study conducted by the Bureau of Agricultural Economics it was found that the credit merchants, as a group, suffered very heavy losses in 1920-21, and they are now making a determined effort to sell on a cash basis. Even in the more prosperous years of 1923 to 1926 it was found that in some areas losses on credit sales to farmers exceeded the interest charges.

The rate of interest charged must needs be high on account of the risk involved. In a survey of North Carolina $(\%, p .32)$ it was found that the annual interest rate was from a little more than 6 per cent to as high as 34 per cent of crop lien credit for the colored cropper. The arerage cost of short-time credit for the whole State was found to be more than 25 per cent. When a crop produced under a crop lien is marketed it is done under the control of the holder of the crop lien, who tries to collect as soon as the annual cash crop is sold.

This prevalence of crop liens held against the members of the association was a large factor in causing nondelivery. The creditors, desiring settlement, were influential in many cases in encouraging or compelling their debtors to sell outside the association, to purchasers who would pay immediately and in full. 
In the tri-State area the auction-floor warehousemen often sell fertilizer and supplies to the tobacco growers; in many cases they take a crop lien on the tobacco crop of the debtor grower. The grower then feels compelled to sell his tobacco at the warehouse of his creditor. In many small towns the local supply or time merchant owns or has interests in the retail store, the tobacco warehouse, the fertilizer business, and other enterprises which the growers patronize. These merchants may refuse to advance credit to the grower unless the latter sells his tobacco in accordance with the merchant's wishes. The fact that many tobacco growers had been purchasing for years much of their fertilizer, feed, and other supplies from the local, longestablished tobacco auction-floor warehousemen or from supply merchants who often were financially interested in independent warehouses, deterred many from becoming members of the cooperative association or made it very difficult for those who did become members to avoid selling on the auction floor.

To sell through the association often meant that the member cut off his former source of credit and became entirely dependent upon his payments from the association to meet his expenses. It meant a sudden change from a six to eight months' credit basis to a cash basis, with the payments for tobacco sales, which were the chief and often sole source of the cash income, small, tardy, and uncertain. Many of the growers were not prepared, especially after two years of low incomes, for this radical change.

In a statement to the Federal Trade Commission the Tobacco Growers' Cooperative Association said (12, $p .45)$ :

Many members of the association were put to a severe test during its first year of operation when they received a first cash advance on their deliveries of approximately 40 per cent as compared with the nonmembers who took all of their money immediately upon the sale of their tobacco on auction floors. This condition caused some contract breaking throughout the entire area where the association received tobacco but especially in eastern North Carolina. where a large proportion of the members were tenant farmers and under obligation to merchants who, in most cases, demanded the quickest method of payment for fertilizers and supplies and thus forced their tenant customers to sell their tobacco for the largest immediate return.

In regard to the effect of the credit condition of the members upon their loyalty to the association, the Agricultural Investigating Committee ${ }^{13}$ reported in 1925 :

The committee finds that the principal cause of nondelivery of tobacco in the beginning was opposition from interests to whom these members were indebted. In certain sections a large number of growers owed warehousemen, time merchants, and others for the money with which they made the 1922 crop. Often the people whom these people owed not only forced them to break their contracts and sell their tobacco on the auction floor but also tried to dissatisfy them with their association.

Because of the small amount of the advances and the slowness of subsequent payments it was difficult for the landowning member to meet his obligations. It was doubly difficult for the landless member who had a crop lien against his tobacco crop and whose creditor was demanding immediate payment for the loan of the past year, and was threatening to give no loan (to tide him over to the next

18 A special committee composed of agricultural officials from the States of Virginia, North Carolina, and South Carolina, as well as editors of several farm papers, which was requested by the association to investigate its affairs for evidences of alleged misman. agement. 
season and to enable him to produce a crop the following year) unless he paid his debts in full, and promptly.

A factor of considerable significance was the effect of the high prices for tobacco and other farm products during the war years in improving the standards of living of the tobacco growers. The striving to maintain these standards increased the dissatisfaction with the association because of its policy of advancing only part of the value of the tobacco and because it failed to make returns to the members which compared favorably with tobacco prices then prevailing on the auction floor or obtained a few years previously.

\section{EDUCATIONAL STANDARDS}

Educational standards are generally relatively low among the farmers of these three States. The rate of illiteracy is high. The 1920 census gives the percentages of illiteracy of rural native whites, 21 years and over, as 9.2 per cent in Virginia, 12.2 per cent in North Carolina, and 10.1 per cent in South Carolina. The rate of illiteracy for the colored rural people of 21 years and over was 34.1 and 34.7 per cent in Virginia and North Carolina, respectively, and 41.3 per cent in South Carolina.

The study of economic and social conditions of 1,014 North Carolina farmers revealed the following facts $(\eta, p .6-7)$ :

Over 31 per cent of the fathers and mothers in the landless families can neither read nor write.

The average cropper had attained a school status of only third grade. The average negro had attained less than full first grade education.

Over 65 per cent of all landless families surveyed take no papers or magazines. Less than 7 per cent take daily papers.

These conditions were found to be largely due to lax and inefficient school systems in the past. The attendance was poor. During certain periods children of school age were kept at home to help with the farm work. The country schools of Virginia, according to the 1925-26 report of the State superintendent of public instruction $(5, p .46-47)$, were only 60.8 per cent efficient. Only 15.4 per cent of the rural boys and girls of 14 to 18 years of age were attending Virginia high schools in 1925-26. The schools of these States have been greatly improved during more recent years.

\section{LACK OF EXPERIENCE IN COOPERATIVE ORGANIZATIONS}

The farming population of the South seems to have had little or no experience in group action, especially of the cooperativebusiness kind, until within recent years. Such general national fraternal organizations as the Farmers' Union, the Farm Bureau Federation, and the National Grange have been in existence in Virginia for some time, but have received little support from farmers and have never proved very successful $(5, p .18-20)$. Their activities have been directed mainly toward legislation and education instead of toward cooperative business organizations. Some of the best work in this direction has been done by the Farm Bureau Federation. There are, at present. several cooperative associations in these States, but most of them are of comparatively recent origin-hare started

$76534-29-3$ 
since 1922. Their membership in Virginia was never very large, exclusive of the membership of the Tobacco Growers' Cooperative Association $(5, p .9)$. Few of these cooperative associations exist in the purely tobacco districts. No satisfactory data in regard to farmers' organizations are available for North Carolina and South Carolina, but apparently conditions are much the same in these States as in Virginia.

In the membership survey made in connection with this study it was found that 67 per cent of the interviewed members had never belonged to any cooperative-marketing association except the Tobacco Growers' Cooperative Association. About 13 per cent had belonged to such social and educational societies as the Farmers' Union, Farmers' Alliance, the Grange, and the Farm Bureau. Of those who had belonged to cooperative-marketing associations, other than the tobacco cooperative, 85 per cent had belonged to the North Carolina and South Carolina cotton cooperatives-which were not formed until 1922. Outside of the cotton and tobacco associations only 4.8 per cent of the producers questioned had belonged to cooperatives. This would mean that prior to 1922 at least 95 per cent of these men had belonged to no cooperative-marketing association and had no cooperative-marketing experience. Many of the farmers had joined the cotton and tobacco associations at the same time, and few had had previous experience in the marketing of their products cooperatirely. Only 9 of the 643 members had belonged to two other cooperatire associations. Table 7 shows, by pools. the number of other associations to which the members of the Tri-State Tobacco Gromers' Asseciation had belonged prior to 1928. It is obvious that prior to the formation of the Tobacco Growers' Cooperative Association the gromers were almost totally lacking in cooperative business experience, and this lack seriously hindered the first attempts.

TABLE 7.-ICmbership in other cooperative and social organizations reported by 643 members of the Tobacco Growers' Cooperative Association

\begin{tabular}{|c|c|c|c|c|c|c|}
\hline \multirow[b]{2}{*}{ Pool } & \multirow[b]{2}{*}{$\begin{array}{c}\text { Members } \\
\text { interviewed }\end{array}$} & \multicolumn{5}{|c|}{ Number reporting membership in- } \\
\hline & & $\begin{array}{c}\text { No other } \\
\text { cooperative } \\
\text { association }\end{array}$ & $\begin{array}{c}1 \text { other co- } \\
\text { operative } \\
\text { association } 1\end{array}$ & $\begin{array}{l}2 \text { other co- } \\
\text { operative } \\
\text { associa- } \\
\text { tions } 1\end{array}$ & $\begin{array}{l}\text { Coopera- } \\
\text { tive cotton } \\
\text { association }\end{array}$ & $\begin{array}{l}\text { Social or- } \\
\text { ganization" }\end{array}$ \\
\hline $\begin{array}{l}\text { Sun cured } \\
\text { Dark fired. } \\
\text { Old belt } \\
\text { Eastern Carolina } \\
\text { South Carolina. }\end{array}$ & $\begin{array}{r}31 \\
102 \\
195 \\
154 \\
161 \\
\end{array}$ & $\begin{array}{r}30 \\
94 \\
175 \\
38 \\
93 \\
\end{array}$ & $\begin{array}{r}1 \\
7 \\
20 \\
111 \\
65\end{array}$ & $\begin{array}{l}0 \\
1 \\
0 \\
5 \\
3\end{array}$ & $\begin{array}{r}0 \\
0 \\
9 \\
112 \\
61 \\
\end{array}$ & $\begin{array}{r}4 \\
17 \\
48 \\
11 \\
3 \\
\end{array}$ \\
\hline Total $\ldots$ & 643 & 430 & 204 & 9 & 182 & 83 \\
\hline
\end{tabular}

1 Including cotton.

2 Farmers' Union, Farmers' Alliance, Grange, Farm Bureau, and Farm Protective Association.

In many of the other States in which cooperation has been successful there are larger numbers of foreign-born farmers and their descendants. Many of these people came from countries where cooperative marketing of some kind has been practiced for many years. They seem to understand more fully the aims and principles of group 
efforts in business and remain more loyal to their organizations because the group spirit is more highly develoned. In the Southern States, the native whites are highly individualistic, and the people are proud of the fact that infiltration of foreign-born farmers has been practically negligible. In North Carolina, in 1920, only 7,099 persons out of a total population of over two and a half million were foreign-born (11). Similar conditions prevail in the other two States. This lack of cooperative experience and spirit no doubt retards considerably any forward movement in the direction of cooperative organization.

The traditional psychological characteristics of farmers are marked in these three States. In Virginia there seemed to be a consensus of opinion that the nonsupport of cooperative associations was due to the fact that farmers "were conservative, individualistic and prone to be suspicious of the officers of their organization, and of each other" $(15, p .5)$. To these usual traits of farmer psychology must be added the lack of cooperative experience and the lack of education of a large part of the farming population in the South. Within recent years the improvement of schools, the advent of motor cars, the improvement of roads, and the building of suitable community centers have tended to break down these barriers of prejudice and individualism. These changes make for a more hopeful future.

Throughout the tobacco districts is found what might be called a tobacco hierarchy, which has for its upper stratum the tobacco buyers who represent the larger tobacco companies and warehouse owners, and for its lower stratum the farmer friends of these people. Many of the buyers and warehousemen are recruited from the farm population or have formed friendships with the more influential farmers in the different districts during the course of their association with the tobacco-buying business. It is a well-known fact, attested to by the Federal Trade Commission (12, p. 20), and many public men in the South, that this leads to some discrimination in the prices paid to farmers, usually at the expense of the less influential groups. The system of buying on average prices enables the buyers to pay somewhat higher prices to those persons with whom they are friends and to offset these high prices by lower prices paid to other farmers.

Just how far this practice prevails, it is impossible to tell, but this study revealed that in some districts it was an important factor in keeping many of the more influential farmers from joining the Tobacco Growers' Cooperative Association. Undoubtedly such a practice, if at all extensive, would tend to divide the farmers among themselves and thus greatly weaken any effort towards united or group action.

Just how the presence of a large negro farming population influenced the tobacco cooperative is difficult to say. The general feeling was that it added to the difficulties because the colored farmers were, on the whole, less willing to join the association and thereby added to the supply of tobacco available on the loose-leaf auction floor.

The characteristics of the negro population are undoubtedly an important factor in the backwardness of the Southern States, espe- 
cially those in which the negro population is large. Most of the characteristics of the negroes, however, tend to make them good cooperators. If the white leaders set a good example, the negroes are prepared to remain faithful to the trust which such leadership imposes upon them. In some districts the colored farmers seemed reluctant to join, but when they joined they usually did as their white neighbors or landlords advised them. The general impression among the members of the association was that on the whole the negro members remained more loyal to the association than the white members. Fear of legal action, need of less money, and less cleverness in avoiding the contract accounted in part for their greater loyalty.

In brief, the low standard of living, the type of farming, the lack of education, extreme individualism, and lack of cooperative experience all serve to retard any movement towards group action. The situation is made still more difficult by the apparent social stratification and the existence of conditions which tend to divide farmer's among themselves. These conditions render much more complex and difficult the problems of cooperative marketing, for, despite good anr able management, and sound organization, policies, and practices, if the members do not or can not live up to their contracts the association can not succeed.

\section{THE ASSOCIATION'S RECEIPTS OF TOBACCO}

\section{ANTICIPATED RECEIPTS}

The association used the United States Department of Agriculture preliminary estimate of $618,000,000$ pounds as the 1920 production of tobacco in Virginia, North Carolina, and South Carolina as the basis for estimating the percentage of the crop under member contracts. According to the revised figures, the 1920 production of tobacco in the three States was $678,330,000$ pounds. On the basis of the revised total, 52 per cent instead of 57 per cent of the production was under contract by the association.

On January 5, 1922, according to sworn statements by the organization committee in authorizing the formation of the association, 64,022 tobacco growers growing 352,601,437 pounds of tobacco had signed. On the basis of this figure, the manager of the field-service department estimated that the association receipts, in 1922, would be $353,-$ 000,000 pounds if a normal crop were produced and if all pledged tobacco were delivered. Allowing a 15 to 20 per cent loss, because of complications in the relations of landlord and tenant, broken contracts, and other causes, it was anticipated that the receipts would be between 282 and 307 million pounds, on the basis of the average production of the five previous years. ${ }^{14}$ Before delivery of the 1922 crop the number of members had increased to 79,643 and the estimated tobacco under contract to $407,255,437$ pounds, as shown in Table 8 .

14 Minutes of board of directors, June, 1922. 
TABLE 8.-Estimated production of tobacco by members under contract in June, 1922, compared with the production in 1920 and number of growers in the tri-State area

\begin{tabular}{|c|c|c|c|c|c|c|}
\hline State & $\begin{array}{l}\text { Total produc- } \\
\text { tion in } 1920^{1}\end{array}$ & \multicolumn{2}{|c|}{ Quantity signed up } & \multirow{2}{*}{\begin{tabular}{|r|}
$\begin{array}{r}\text { Growers } \\
\text { in State }\end{array}$ \\
Number \\
49,596 \\
94,274 \\
19,281
\end{tabular}} & \multicolumn{2}{|c|}{$\begin{array}{c}\text { Growers in associa- } \\
\text { tion }\end{array}$} \\
\hline $\begin{array}{l}\text { Virginia } \\
\text { North Carolina } \\
\text { South Carolina }\end{array}$ & $\begin{array}{c}\text { Pounds } \\
179,580,000 \\
433,750,000 \\
65,000,000\end{array}$ & $\begin{array}{c}\text { Pounds } \\
136,250,121 \\
232,167,492 \\
38,837,824\end{array}$ & $\begin{array}{r}\text { Per cent } \\
75.9 \\
53.5 \\
59.8\end{array}$ & & $\begin{array}{r}\text { Number } \\
31,226 \\
40,243 \\
8,174\end{array}$ & $\begin{array}{r}\text { Per cent } \\
63.0 \\
42.7 \\
42.4\end{array}$ \\
\hline Total. & $678,330,000$ & $407,255,437$ & 60.0 & 163,151 & 79,643 & 48.8 \\
\hline
\end{tabular}

1 Yearbook, U. S. Department of Agriculture, 1921.

21925 Census of Agriculture (10, pt. 2, County Tables IV, VI). The 1924 census number of farms in the 3 States is more conservative than that of 1919 , when the number was 176,295 . The latter figure would reduce the percentage of members who joined to 45.2 per cent.

At the meeting of the board of directors on August 29, 1922, the director of warehouses stated that it was his opinion that the association would receive $25,000,000$ pounds in South Carolina, $70,000,000$ pounds in eastern Carolina, 170,000,000 pounds in the "old belt," and $40,000,000$ pounds in the dark-tobacco territory, or a total of approximately $300,000,000$ pounds from the entire area.

Table 8 shows that 60 per cent of the crop supposedly was under contract by June, 1922 , and that 48.8 per cent of the growers signed the marketing contract. Table 9 shows the average number of pounds of tobacco produced per grower in 1920, according to data from the 1920 census, and the production per member, according to estimates of the association.

The number of acres necessary to obtain the production per member estimated, based on the Department of Agriculture figures of average production per acre for the period 1921-1925, is shown in Table 10.

TABLE 9.-Production of tobacco per farm, 1920, as reported by members in their association contracts, compared with computed average for all tobacco growers in the tri-State area

\begin{tabular}{|c|c|c|c|}
\hline \multirow{2}{*}{ State } & \multicolumn{2}{|c|}{ A verage production of- } & \multirow{2}{*}{$\begin{array}{c}\text { Members' } \\
\text { excess }\end{array}$} \\
\hline & $\begin{array}{l}\text { All grow- } \\
\text { ers } 1\end{array}$ & Members & \\
\hline $\begin{array}{l}\text { Virginia } \\
\text { North Carolina- } \\
\text { South Carolina-. }\end{array}$ & $\begin{array}{r}\text { Pounds } \\
3,621 \\
4,601 \\
3,371\end{array}$ & $\begin{array}{r}\text { Pounds } \\
4,363 \\
5,769 \\
4,751\end{array}$ & $\begin{array}{r}\text { Pounds } \\
742 \\
1,168 \\
1,380\end{array}$ \\
\hline A verage ${ }^{2}$ & 4,158 & 5,114 & 956 \\
\hline
\end{tabular}

1 Production divided by number of farms reporting tobacco grown in 1924, according to the Census of Agriculture. If the 1920 census figures for the number of growers is used the members' excess figure is 310 pounds greater, or 1,266 pounds for the 3 States instead of 956 pounds.

${ }^{2}$ Weighted. 
The quantity of tobacco under contract to the association was overestimated. (Tables 9 and 10.) According to the association's figures, the arerage member would have to cultivate 7.8 acres to produce the quantity credited to him, whereas the census figures show that the arerage grower had only 4.1 acres under cultivation. Again, the average actual 1924 production per grower for the three States was only 2,822 pounds instead of an anticipated per member delivery of an average of $\check{5}, 114$ pounds..$^{15}$

It is possible that the association's membership contained a high percentage of the larger growers or that the average acreage per member may have been actually greater than that of nonmembers. The number of tobacco growers may have increased from 1922 to 1924; the acreage or production per acre of the signers may have been overestimated or exaggerated; the tenant or landlord may have signed for all tobacco produced on the farm and not for just the part controlled by him; or possibly some tobacco growers were not included in the census figures.

TABLE 10.-Acreage of tobacco per farm needed for production reported by the members on their contracts compared with acreage yields and average acreage in the tri-State area in 1924

\begin{tabular}{|c|c|c|c|c|c|}
\hline \multirow[b]{2}{*}{ State } & \multirow[b]{2}{*}{$\begin{array}{l}\text { Average } \\
\text { yield per } \\
\text { acre 1921- } \\
1925^{1}\end{array}$} & \multirow[b]{2}{*}{$\begin{array}{l}\text { Sign-up } \\
\text { per } \\
\text { member }\end{array}$} & \multicolumn{3}{|c|}{ Acreage per farm } \\
\hline & & & $\begin{array}{l}\text { Required } \\
\text { to produce } \\
\text { sign-up at } \\
\text { \&verage } \\
\text { yields }\end{array}$ & $\begin{array}{l}\text { 1924, all } \\
\text { farms }\end{array}$ & $\begin{array}{l}\text { Associa- } \\
\text { tion } \\
\text { excess }\end{array}$ \\
\hline 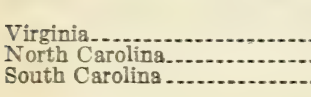 & $\begin{array}{r}\text { Pounds } \\
667 \\
607 \\
645\end{array}$ & $\begin{array}{r}\text { Pounds } \\
4,363 \\
5,769 \\
4,751\end{array}$ & $\begin{array}{l}\text { Acres } \\
6.54 \\
9.50 \\
7.37\end{array}$ & $\begin{array}{l}\text { Acres } \\
3.93 \\
4.32 \\
4.07\end{array}$ & $\begin{array}{l}\text { Acres } \\
2.61 \\
5.18 \\
3.30\end{array}$ \\
\hline A verage............. & 640 & 25,114 & 7.80 & 4. 11 & 3.70 \\
\hline
\end{tabular}

1 Data from Yearbooks of Agriculture, 1921-1927.

Data from Census of Agriculture, 1924.

Weighted average.

\section{ACTUAL RECEIPTS}

Whatever may have been the cause, the estimate of the receipts was too optimistic. Although the association was launched on the basis of a minimum delivery of 50 per cent of the total production of the three States during the first year, only 35.4 per cent of the production for that year was delivered to the association. (Table 11; fig. 13.) In 1923, deliveries increased in volume because of a large crop but decreased relatively; only 28.5 per cent of the total production was received. In 1924 and 1925 , deliveries fell to 22.9 per cent and 14.6 per cent, respectively.

Table 12 shows that the association obtained, throughout, the highest percentage of deliveries in Virginia but that, even in this State, the percentage decreased each year. The deliveries in South Carolina remained fairly constant on the whole, if anything, tending to improve during the last rear-partly because of increased

${ }_{15}$ Data from U. S. Department of Agriculture Yearbook, 1924, and the Census of Agriculture, 1925 (10). 
membership. But it was in eastern North Carolina (or the new belt) where members defaulted most. In this district, in which about a third of the flue-cured tobacco of the three States is grown, the association failed to obtain a 20 per cent delivery even the first year. Conditions went from bad to worse, and in 1925 , only 5.2 per cent of the tobacco produced in this district was delivered to the association. The organization was practically nonexistent in this district during 1925 .

Some falling-off in the percentage of the crop delivered during the last years was natural because the association's membership did not increase sufficiently to take care of those who ceased to be active members through the turnover among the owners and operators

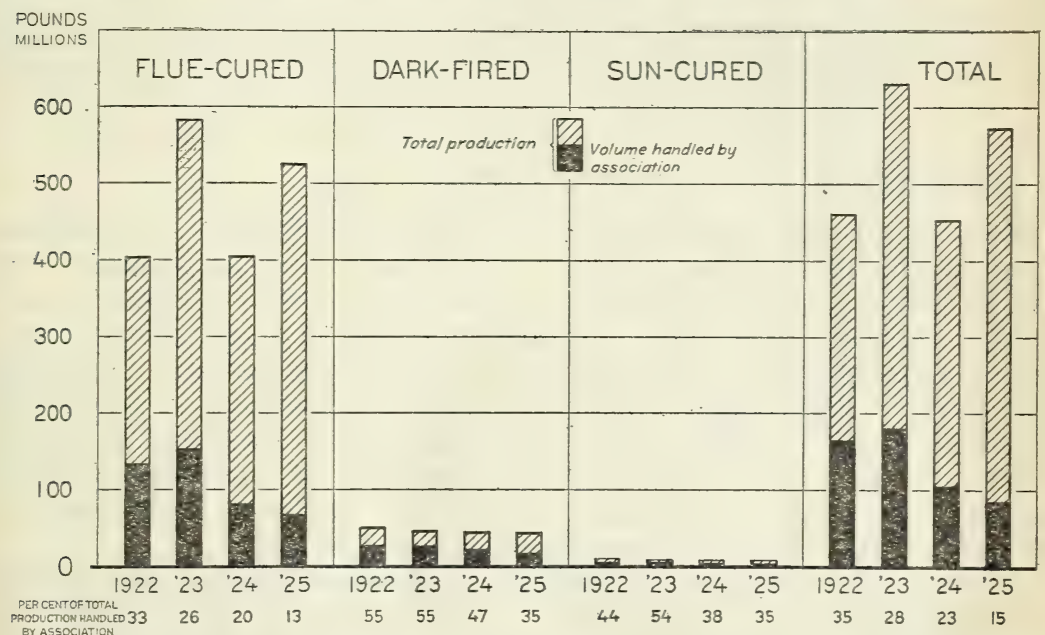

\section{Figure 13.-PROdUCtION OF TOBACCO IN TRI-STATE AREA AND RECEIPTS By ASSOCIATION, BY TYPES, 1922-1925}

From 35.4 per cent of the production of the tri-State area in 1922 the receipts of the association decreased to 28.5 per cent in 1922 , to 22.9 per cent in 1924 , and to 14.6 per cent in 1925 .

of farms. It is also probable that many nonmember farmers began to grow tobacco or to increase their acreage more than the members did because the nonmembers anticipated or felt immediately the effect of the high prices.

TABLE 11.-Tobacco production in the tri-State area and deliveries to the association, by classes, 1922-1925

\begin{tabular}{|c|c|c|c|c|c|c|c|c|c|c|c|c|}
\hline \multirow{2}{*}{ Class } & \multicolumn{4}{|c|}{ Total production ${ }^{1}$} & \multicolumn{4}{|c|}{ Deliveries to association } & \multicolumn{4}{|c|}{$\begin{array}{l}\text { Percentage of crop de- } \\
\text { livered to association }\end{array}$} \\
\hline & 1922 & 1923 & 1924 & 1925 & 1922 & 1923 & 1924 & 1925 & 1922 & 1923 & 1924 & 1925 \\
\hline $\begin{array}{l}\text { Sun-cured.-- } \\
\text { Dark-fired.- } \\
\text { Flue-cured.- }\end{array}$ & $\begin{array}{r}\text { 1,000 } \\
\text { lbs. } \\
8,162 \\
49,080 \\
404,608\end{array}$ & $\begin{array}{r}1,000 \\
\text { lbs. } \\
5,586 \\
43,754 \\
583,380\end{array}$ & $\begin{array}{c}1,000 \\
\text { lbs. } \\
5,600 \\
43.125 \\
405,805\end{array}$ & $\begin{array}{r}1,000 \\
\text { lbs. } \\
5,705 \\
42,040 \\
525,708\end{array}$ & $\begin{array}{l}1,000 \\
\text { lbs. } \\
3,580 \\
26,824 \\
133,186\end{array}$ & $\begin{array}{r}1,000 \\
\text { lbs. } \\
3,020 \\
24,149 \\
152,969\end{array}$ & $\begin{array}{c}1,000 \\
\text { lbs. } \\
2,117 \\
20,226 \\
81,498\end{array}$ & $\begin{array}{c}1,000 \\
\text { lbs. } \\
1,973 \\
14,506 \\
67,155\end{array}$ & $\begin{array}{l}43.86 \\
54.65 \\
32.92\end{array}$ & $\begin{array}{l}54.06 \\
55.19 \\
26.22\end{array}$ & $\begin{array}{l}37.80 \\
46.90 \\
20.08\end{array}$ & $\begin{array}{l}34.58 \\
34.50 \\
12.77\end{array}$ \\
\hline Total.. & 461,850 & 632,720 & 454,530 & 573,453 & 163,590 & 180,138 & 103,841 & 83,634 & 35.42 & 28.47 & 22.85 & 14. 58 \\
\hline
\end{tabular}

1 U. S. Department of Agriculture Yearbooks, 1923-1926. 
TABLE 12.-TObacco production in the tri-State area and deliveries to the association, by States, 1922-1925

\begin{tabular}{|c|c|c|c|c|c|c|c|c|c|c|c|c|}
\hline \multirow{2}{*}{ State } & \multicolumn{4}{|c|}{ Total production ${ }^{1}$} & \multicolumn{4}{|c|}{ Deliveries to association } & \multicolumn{4}{|c|}{$\begin{array}{l}\text { Percentage of crop deliv- } \\
\text { ered to association }\end{array}$} \\
\hline & 1922 & 1923 & 1924 & 1925 & 1922 & 1923 & 1924 & 1925 & 1922 & 1923 & 1924 & 1925 \\
\hline Virginia & $\begin{array}{c}1,000 \\
\text { libs. } \\
154,950\end{array}$ & $\left|\begin{array}{c}1,000 \\
\text { lbs. } \\
148,760\end{array}\right|$ & $\begin{array}{c}1,000 \\
\text { lbs. } \\
133,770\end{array}$ & $\left|\begin{array}{c}1,000 \\
\text { lbs. } \\
126,148\end{array}\right|$ & $\left|\begin{array}{l}1,000 \\
l b s . \\
83,353\end{array}\right|$ & $\begin{array}{l}1,000 \\
\text { lbs. } \\
77,490\end{array}$ & $\begin{array}{l}1,000 \\
\text { libs. } \\
56,769\end{array}$ & $\begin{array}{l}1,000 \\
\text { lbs. } \\
38,099\end{array}$ & 53.79 & 52.09 & 42.44 & 30.20 \\
\hline $\begin{array}{l}\text { North Carolina: } \\
\text { New belt..... } \\
\text { Old belt..... }\end{array}$ & $\begin{array}{l}140,500 \\
112,000\end{array}$ & $\begin{array}{l}236,300 \\
173,200\end{array}$ & $\begin{array}{l}143,180 \\
131,990\end{array}$ & 127,402 & $\begin{array}{l}27,334 \\
36,976\end{array}$ & $\begin{array}{l}33,950 \\
41,171\end{array}$ & $\begin{array}{l}12,160 \\
23,836\end{array}$ & $\begin{array}{l}12,810 \\
13,001\end{array}$ & \begin{tabular}{|l|}
19.45 \\
1 \\
33.01
\end{tabular} & $\begin{array}{l}14.37 \\
23.77\end{array}$ & $\begin{array}{r}8.49 \\
18.06\end{array}$ & $\begin{array}{r}5.16 \\
10.17\end{array}$ \\
\hline $\begin{array}{l}\text { Total North } \\
\text { Carolina.. }\end{array}$ & 252,500 & 409,500 & 275,170 & 376,265 & 64,310 & 75,121 & 35,996 & 25,811 & 25.47 & 18.34 & 13.08 & 6.86 \\
\hline South Carolina... & 54,400 & 74,460 & 45,590 & 71,040 & $\overline{15,927}$ & $\overline{27,527}$ & 11,076 & 19,724 & 29.28 & 36.97 & 24.30 & 27.76 \\
\hline Total. & 461,850 & 632,720 & 454,530 & 573,453 & 163,590 & 180,1381 & 103,841 & 83,634 & 35.42 & 28.47 & 22.85 & 14.58 \\
\hline
\end{tabular}

1 U. S. Department of Agriculture, Yearbooks, 1923-1926.

Records of the association were analyzed further to ascertain whether the unexpectedly small deliveries in certain districts were due to lower average deliveries per member or to deliveries from a smaller number of members. Table 13 shows the approximate number of members who delivered, each year, by pool areas. It will be seen that, in 1922, member defections were very heavy in the eastern Carolina pool. In the other pools nearly all members delivered. After the first year, however, the number of members declined rapidly, especially in the eastern Carolina territory, where only 15 per cent of the registered members delivered in 1925.

A comparison of the percentage of members delivering in 1922 with the percentage of deliveries to production in Table 12 leads to the conclusion either that a large number of members delivered only part of their crop or that the members signed up by the association did not include many large producers. The disparity between the percentages is probably due to both causes. From a sample of 200 deliveries at each of six different warehousing centers, however, no tendency was found for individual members to deliver smaller volumes of tobacco during the last two years.

Table 14 shows the percentages of members who delivered tobacco to the association each year, according to a sample survey which was made at four markets, in 1922, on the basis of 200 members at each market. The data showed that there was a decrease in the number of members delivering but not that those members delivering actually delivered a smaller proportion of their crops or grew less tobacco. 
TABLE 13.-Membership in the several pools and members delivering tobacco to their association, crops of 1922-1926

\begin{tabular}{|c|c|c|c|c|c|c|c|c|c|c|c|c|}
\hline \multirow[b]{2}{*}{ Pool } & \multicolumn{4}{|c|}{$\begin{array}{l}\text { Membership contracts } \\
\text { signed to- }\end{array}$} & \multicolumn{8}{|c|}{$\begin{array}{c}\text { Members delivering tobacco to the association } \\
\text { crop of }-1\end{array}$} \\
\hline & $\begin{array}{l}\text { Sep- } \\
\text { tem- } \\
\text { ber, } \\
1922\end{array}$ & $\begin{array}{c}\text { Dec. } \\
31, \\
1923\end{array}$ & $\begin{array}{c}\text { Dec. } \\
31, \\
1924\end{array}$ & $\begin{array}{c}\text { Dec. } \\
31, \\
1925\end{array}$ & 1922 & 1923 & 1924 & 1925 & 1922 & 1923 & 1924 & 1925 \\
\hline $\begin{array}{l}\text { Sun-cured and } \\
\text { dark-fired......... } \\
\text { Old belt } \\
\text { Eastern Carolina.. } \\
\text { South Carolina.... }\end{array}$ & $\begin{array}{c}\begin{array}{c}\text { Num- } \\
\text { ber } \\
14,704 \\
35,343 \\
19,206 \\
10,390\end{array}\end{array}$ & \begin{tabular}{|c|} 
Num. \\
ber \\
17,600 \\
42,000 \\
20,000 \\
12,300
\end{tabular} & $\begin{array}{c}\text { Num- } \\
\text { ber } \\
18,000 \\
42,800 \\
20,300 \\
13,300\end{array}$ & $\begin{array}{c}\text { Num- } \\
\text { ber } \\
18,100 \\
42,900 \\
20,400 \\
15,000\end{array}$ & $\begin{array}{c}\text { Num- } \\
\text { ber } \\
13,100 \\
34,100 \\
11,750 \\
10,000\end{array}$ & $\begin{array}{r}\text { Num- } \\
\text { ber } \\
15,150 \\
35,700 \\
8,150 \\
9,900\end{array}$ & $\begin{array}{r}\text { Num- } \\
\text { ber } \\
12,580 \\
30,950 \\
4,650 \\
7,600\end{array}$ & 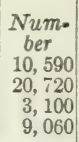 & $\begin{array}{r}\text { Per } \\
\text { cent } \\
89 \\
96 \\
61 \\
96\end{array}$ & $\begin{array}{r}\text { Per } \\
\text { cent } \\
86 \\
85 \\
41 \\
80\end{array}$ & \begin{tabular}{|} 
Per \\
cent \\
70 \\
72 \\
23 \\
57
\end{tabular} & $\begin{array}{r}\text { Per } \\
\text { cent } \\
59 \\
48 \\
15 \\
60\end{array}$ \\
\hline Total & 79,643 & 91,900 & 94,400 & 96,400 & 68,950 & 68,900 & 55,780 & 43,470 & 87 & 75 & 59 & 45 \\
\hline
\end{tabular}

1 The delivery records of the association did not provide means of an exact count.

TABLE 14.-Delivery performance of 800 members: Percentage of those delivering in 1922 who delivered in succeeding years ${ }^{1}$

\begin{tabular}{|c|c|c|c|c|}
\hline Market & 1922 & 1923 & 1924 & 1925 \\
\hline 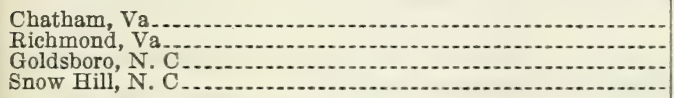 & $\begin{array}{l}100 \\
100 \\
100 \\
100\end{array}$ & $\begin{array}{l}30.0 \\
72.0 \\
31.0 \\
40.5\end{array}$ & $\begin{array}{l}31.0 \\
51.0 \\
13.5 \\
21.5\end{array}$ & $\begin{array}{r}33.5 \\
39.5 \\
\text { (2) } \\
7.5\end{array}$ \\
\hline
\end{tabular}

1 At random 200 members were taken at each of the 4 markets.

2 No data available for 1925 .

According to the membership study, in reply to the question, "When did you first sell outside?", 13.6 per cent of those who sold outside admitted first doing so in $1922 ; 22.1$ per cent, in $1923 ; 28.2$ per cent, in 1924; 32.4 per cent, in 1925; and the remainder stated that they did not know when they first broke their contracts. Of all the members visited, 44 per cent admitted having sold outside of the association. The percentages of members, by pools, who said that they sold tobacco on the auction floor during the period 1922 to 1925 , were as follows: Sun-cured pool, 10 per cent; dark-fired, 11.1 per cent; old belt, 28.7 per cent; eastern Carolina, 64.7 per cent; South Carolina, 70.8 per cent.

Table 15 gives the replies of those who admitted selling tobacco outside of the association, in answer to the question as to why they sold outside. The reason most frequently given was that they were forced to sell outside; 84 or about one-third gave this reply. Higher prices on the outside was the reason given by 62 members. Other important reasons were as follows: Association payments were too low; everybody else was selling outside; the association had failed.

Probably the outstanding fact presented in Table 16, in regard to the justification of selling outside of the association, is that practically 70 per cent of the members interviewed in the new belt of eastern North Carolina felt that the contract breakers were justified. The percentages replying thus in the other belts were much smaller, especially in the sun-cured and dark-fired pools. Over half of the 643 members questioned felt that the selling outside was not justified. 
The number who justified the sales on the outside is about the same as the number who sold on the outside, which suggests justification of their own action in the reasons given.

TABLE 15.-Replies to question, "Why did you sell outside of the association?" 1

\begin{tabular}{|c|c|c|c|c|c|c|}
\hline \multirow[b]{2}{*}{ Reply } & \multicolumn{6}{|c|}{ Replies made by members of- } \\
\hline & $\underset{\text { pool }}{\text { Sun-cured }}$ & $\begin{array}{c}\text { Dark-fired } \\
\text { pool }\end{array}$ & $\begin{array}{c}\text { Old-belt } \\
\text { pool }\end{array}$ & $\begin{array}{c}\text { Eastern } \\
\text { Carolina } \\
\text { pool }\end{array}$ & $\begin{array}{c}\text { South } \\
\text { Carolina } \\
\text { pool }\end{array}$ & All pools \\
\hline $\begin{array}{l}\text { Forced to sell outside } \\
\text { Prices higher on outside } \\
\text { Everybody else selling outside } \\
\text { Association had failed. } \\
\text { Association payments too low } \\
\text { Other crops not paid for } \\
\text { Association payments too slow } \\
\text { A ssociation did not live up to contract.. } \\
\text { Other replies } \\
\text { No reply }\end{array}$ & $\begin{array}{r}\text { Number } \\
0 \\
0 \\
0 \\
0 \\
0 \\
0 \\
0 \\
0 \\
0 \\
3\end{array}$ & $\begin{array}{r}\text { Number } \\
3 \\
3 \\
2 \\
0 \\
0 \\
0 \\
0 \\
0 \\
4 \\
4\end{array}$ & $\begin{array}{r}\text { Number } \\
20 \\
21 \\
8 \\
10 \\
1 \\
1 \\
0 \\
3 \\
9 \\
0\end{array}$ & $\begin{array}{r}\text { Number } \\
51 \\
27 \\
8 \\
5 \\
13 \\
4 \\
2 \\
1 \\
21 \\
0\end{array}$ & $\begin{array}{r}\text { Number } \\
10 \\
11 \\
0 \\
1 \\
0 \\
1 \\
2 \\
0 \\
7 \\
2\end{array}$ & $\begin{array}{r}\text { Number } \\
84 \\
62 \\
18 \\
16 \\
14 \\
6 \\
4 \\
4 \\
41 \\
9\end{array}$ \\
\hline Total ... & 3 & 16 & 73 & 132 & 34 & 258 \\
\hline Member interviews... & 31 & 102 & 195 & 154 & 161 & 643 \\
\hline
\end{tabular}

1 Asked of the 258 members who admitted selling on the outside.

TABLE 16.-Replies to question, "Do you think members were justified in selling tobacco outside of the association?"

\begin{tabular}{|c|c|c|c|c|c|c|}
\hline \multirow[b]{2}{*}{ Reply } & \multicolumn{6}{|c|}{ Replies made by members of- } \\
\hline & $\begin{array}{c}\text { Sun-cured } \\
\text { pool }\end{array}$ & $\begin{array}{c}\text { Dark-fired } \\
\text { pool }\end{array}$ & $\begin{array}{l}\text { Old-belt } \\
\text { pool }\end{array}$ & $\begin{array}{c}\text { Eastern } \\
\text { Carolina } \\
\text { pool }\end{array}$ & $\begin{array}{l}\text { South } \\
\text { Carolina } \\
\text { pool }\end{array}$ & All pools \\
\hline No...... & ${ }_{29}^{\text {Number }}$ & ${ }_{72}^{\text {Number }}$ & $\begin{array}{r}\text { Number } \\
97\end{array}$ & $\begin{array}{r}\text { Number } \\
38\end{array}$ & $\begin{array}{r}\text { Number } \\
114\end{array}$ & $\begin{array}{r}\text { Number } \\
350\end{array}$ \\
\hline 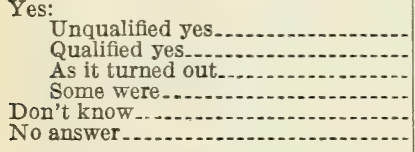 & $\begin{array}{l}2 \\
0 \\
0 \\
0 \\
0 \\
0\end{array}$ & $\begin{array}{r}15 \\
3 \\
6 \\
2 \\
3 \\
1\end{array}$ & $\begin{array}{r}64 \\
14 \\
10 \\
7 \\
3 \\
0\end{array}$ & $\begin{array}{r}107 \\
3 \\
2 \\
2 \\
-\quad 1 \\
-\quad 3 \\
0\end{array}$ & $\begin{array}{r}35 \\
8 \\
0 \\
0 \\
3 \\
1\end{array}$ & $\begin{array}{r}223 \\
28 \\
18 \\
10 \\
12 \\
2\end{array}$ \\
\hline Total & 31 & 102 & 195 & 154 & 161 & 643 \\
\hline
\end{tabular}

\section{MANAGEMENT POLICIES AND THEIR RELATION TO FAILURE OF ASSOCIATION}

Mistakes which now stand out clearly were scarcely discernible when the cooperative association was established, and many policies were forced upon the association by circumstances over which it had no control. Much criticism has been directed against persons in charge of the affairs of the association. Unless the prevailing circumstances are taken into consideration such criticism is likely to be unfair. The association's failure was not caused primarily by lack of sympathetic interest or devotion to duty on the part of the leaders, but was caused by forces insidious in their effects which gradually undermined the morale of the whole organization. Many of those who remained loyal to the association until the end earned for themselves only the ridicule of their less conscientious neighbors. 


\section{EXPERIENCE AND ATTITUDE OF DIRECTORS}

The directors frequently have been criticized for lack of insight into the affairs of the association and for laxity in attendance at meetings. The minutes of the association show that there were over 20 of the 25 members present at 27 out of 57 meetings of the board of directors. During the course of four years there was only one meeting at which less than 17 members were present. The average number of directors absent at each meeting was less than 4 for the four years. A large number of directors were present at every meeting, and few were absent from more than three meetings each year. At less than one-third of the meetings were more than 3 of the 25 directors absent.

The three public directors created 61 of the total 219 absences at the 57 meetings. At 13 of the 57 meetings all of the public directors were present. At 31 meetings 1 was absent; at 9,2 were absent; and at 4 (two meetings in succession) all 3 were absent. On the face of this evidence it would appear that the elected directors at least were very conscientious in their attendance.

A far more likely explanation of the inefficiency of the board lies in the fact that few of the directors had any intimate knowledge of tobacco marketing, nor had they close knowledge of the affairs of the association because of its great size and the technicality and complexity of many of the problems which it had to solve. Although many of them were good business men, their experience had theretofore been confined to more routine business such as farming, banking, and retail merchandising. From the very nature of things, many of the more complicated and intricate matters arising in the association were left in the hands of a few persons-some of whom unfortunately did not adopt policies that were in the best interests of the association.

The members of the board of directors were unable to keep closely in touch with the association's problems by meeting one or two days a month and hearing the reports and recommendations of the general manager, the executive committee, or the special committees. The board members, often not having even heard of the report or recommendation before and believing that the propounder had sufficient insight into the matter, were prone to affirm or deny the matter as was recommended to them. If a board has implicit faith in its officials, the officers may take advantage of the fact; if it does not have this faith it may still be passive because of the lack of time or knowledge to refute the recommendation offered or to substitute a better one. If the members of a board are informed in advance of the proposed motions or recommendations which are to come before the meeting they will have time for thought, consultation, and search into the matters under consideration, and will be able to give them careful and intelligent deliberation.

At least nine of the directors of the association were salaried officials. (See Table 21.) The salaries of these officials were necessarily fixed by the executive committee and the board of directors. In other words, these two bodies were given the privilege of recommending and indorsing the salaries of some of their own members.

Outside the members of the executive committee, except under unusual circumstances, directors of cooperatives should not be employed in salaried positions of their own association, and under no circum- 
stances should officials and employees be allowed to have any financial interest in a concern with which the association has business dealings. Trusted and highly-paid officials have no right to exploit their connection with an association to their own advantage. One of the officials of the tri-State association was in charge of the sale of all association tobacco. There was the danger that his connection with the Edmondson Tobacco Co. may have made him less interested in the sale of green tobacco, for the more tobacco that was redried and sent to his plant, the more profits would accrue to him and his company. He may have made use of his strategic position as sales manager to have enough tobacco diverted to the Edmondson Tobacco Co. to have assured that the plant was kept working at full capacity.

Failure of the board of directors to employ a full-time executive, with the necessary power and experience to coordinate the functions of the different departments in a smoothly-working organization from the outset, further militated against success. When the association was organized the leaders had a fairly good conception of what it should accomplish, but they did not have experience in any business of a similar nature upon which to base their policies. They were venturing into an uncharted and unknown field. It is well to stress these points, for they must be faced when an attempt is made to bring into existence, in a relatively short time, an organization of the size of the Tobacco Growers' Cooperative Association.

\section{MEMBERSHIP POLICIES}

It is evident that conditions within the area would have made success difficult in any event, and that in this situation the adoption of carefully prepared plans of membership contact and information regarding the purposes of the association was highly essential.

\section{FIELD SERVICE}

Field-service men were employed to supervise the different districts. They helped to organize local units, addressed local and public meetings, visited individual farmers, and attempted generally to promote the welfare of the association among the farmers. But they were too few in number, and in some instances at least it would appear that the type of men employed was undesirable. At the same time some were men and women of the very highest caliber. The field-service department was under the control of a director of the association who was an active leader in its formation.

It is estimated that at one time the association had 1,800 locals. The local units were of an educational and discussional nature, and were formed to maintain the interest of the members, to teach them the principles of cooperation, and to help to build a community spirit. Some of these locals passed resolutions, many of which were forwarded to the board of directors. Such resolutions undoubtedly influenced the board in its policies, but it was not incumbent upon the board to accept the views expressed or to take any action thereon. Unfortunately, meetings of local units were generally not well attended, and as a consequence locals in some districts were never strong or active. They failed to reach those members who were most lacking in knowledge of and loyalty to the association. A large proportion 
of the members displayed an appalling lack of interest in the affairs of the association, which they soon came to look upon as an organization apart from themselves.

A comprehensive plan of organization and program of work for the field-service department was submitted to the board of directors by the field-service department in August, 1922, but the plan, although favorably commented upon, was never put into action, largely because of expense and because the board did not then realize the necessity of a strong field-service department. The field-service department was at no time given enough assistance or power by the board to perform its functions in such a way as to be of the needed value to the association.

In 1925 , as a result of recommendations by the agricultural investigation committee, the department was considerably strengthened, but it was then too late. The members generally had become suspicious of the field-service men because they feared that the field men were in most instances attempting to secure information in regard to contract violators and violations with the intention of using this information in prosecutions. This suspicion, even during the earlier years of the operation of the association, prevented the field-service work from being as effective as it might otherwise have been, especially in the more disloyal districts.

An important function of the field-service department was the publication of the monthly official organ, the Tri-State Tobacco Grower. This journal, a copy of which was sent to every member, was published to convey to members the news of the activities of their association. Unfortunately much space was deroted to material which may be described as propaganda, and to articles denouncing the tactics of the opposition. Reference was seldom made to the complexity or difficulty of the problems encountered by the association. It is doubtful, however, whether this would have done much good, as a large proportion of the farmers did not have the necessary training and experience to enable them to appreciate the significance of the principles involved $(5, p .95)$. It was found that a large number of members failed to read the official house organ, ${ }^{16}$ just as they failed to attend the meetings of the local units. The official organ was supplemented by a weekly news letter, which was sent to all locals to be read at their meetings. But as these locals frequently had only a small attendance, the usefulness of the news letter was limited to comparatively few members and, for the most part, to the interested and more intelligent and loyal members.

\section{LEGAL STATUS OF THE ASSOCIATION}

According to the membership agreement the Tobacco Growers' Cooperative Association was to be organized under the laws of the State of North Carolina if by July 1, 1921, the appropriate legislation had been there enacted-otherwise under the laws of the State of Tennessee-and if by this date signatures of tobacco growers or persons eligible to membership, covering at least one-half of the aggregate production of tobacco in North Carolina, Virginia, and South Carolina in 1920, had been secured. The required quantity of

${ }^{16}$ Report of the agricultural investigation committee section on membership department 
tobacco was not signed up until January, 1922, so the association did not handle the 1921 crop. On February 9, 1922, as a nonstock, nonprofit association, the Tobacco Growers' Cooperative Association was incorporated under the cooperative marketing act of North Carolina ${ }^{17}$ for the purposes of intelligently " promoting, fostering, and encouraging the business of marketing tobacco cooperatively; for reducing speculation; for stabilizing the local tobacco markets; for cooperatively and collectively handling the problems of tobacco growers; and for other pertinent purposes." 18

From the standpoint of legislation under which to operate, the association was fortunate. The three States comprising the territory of the association have laws with practically identical provisions designed especially to aid farmers in cooperatively marketing their products. These laws passed in 1921 and early in 1922 are substantially the same in their provisions as those of 35 other States.

The North Carolina law provides that five or more persons engaged in the production of agricultural products may form a nonprofit cooperative association to engage in any activity in connection with the marketing and selling of the products of the members of the association or with the harvesting, preserving, drying, processing, canning, packing, storing, handling, or shipping thereof. The members must be producers of agricultural products, and the association may handle only the products of its members.

The articles of incorporation of an association formed under the act must contain a statement showing whether the association is organized with or without capital stock; whether the property rights of the members shall be equal or unequal; if unequal, general rules must be made applicable to all members, whereby property rights will be determined, and these rules may not be changed except by consent of three-fourths of the members.

Provision is also made for by-laws protecting the rights of members and conserving the status of the association as a nonprofit corporation for marketing cooperatively products of the members, with the usual stipulations for the time, place, and manner of calling and conducting meetings; the number of members constituting a quorum; the right to vote by proxy; and the powers and duties of officers and directors.

The act also provides that associations formed under it may contract with their members requiring the members to sell their products through the association or any facilities created by the association, with or without taking title thereto, and pay over to its members the resale price after making authorized deductions. Provision is made for liquidated damages, and in the event of a breach or threatened breach of the marketing agreement the association is entitled to an injunction to prevent further breach of the contract and to a decree of specific performance.

An association formed under the act may organize, operate, own, control, or have interest in, any other corporation engaged in preserving, drying, processing, canning, packing, storing, handling, shipping, manufacturing, or marketing products handled by the association.

${ }_{17}$ The North Carolina cooperative marketing act had been ratifled March 7, 1921.

18 'Tobacco Growers' Cooperative Association agreement, p. 1. 
The question of the constitutionality of the cooperative marketing act of North Carolina was raised in the fall of 1922 by a member of the Tobacco Growers' Cooperative Association in an action which the association brought against him for liquidated damages covering tobacco already sold, and for an injunction to prevent him from disposing of the remainder of his 1922 crop of tobacco outside the association. This member contended that the marketing act was unconstitutional and that the contract between him and the association was invalid because it was in restraint of interstate and intrastate commerce. The Supreme Court of North Carolina held that the act was constitutional. ${ }^{19}$

AUXILIARY LEGISLATION

In addition to the cooperative marketing laws, auxiliary legislation was later enacted, designed to establish helpful protection for the farmers.

A law of South Carolina, approved March 18, 1924, provides " for the recording of marketing contracts or agreements entered into by agricultural producers and cooperative corporations and cooperativemarketing associations and their members." 20 This law after authorizing those organizations subject to its provisions to record contracts made with their members, states:

When this Act shall have been complied with, and any such record as is herein mentioned is made in the county in which the member of said association resides such record shall operate as constructive notice of the existence of such contract or agreement, and of the terms thereof (and all persons contracting or dealing with any such member in relation to any such produce covered by such contract or agreement shall be bound thereby, and all rights or liens acquired by any such person in such produce subsequent to the date of such record shall be subject in all respects to the rights of the association under such contract or agreement): Provided, however, That nothing herein contained shall affect the statutory lien of a landlord for rent and advances and labor's liens: And provided further, That this Act shall not have the effect of conferring upon such association any power over its members, or of imposing upon its members any duties not now possessed by the association or owing by the members under existing contract. Nothing contained herein shall be construed to affect the rights of a share-cropper as they now exist under the laws of the State of South Carolina : Provided, That if any agricultural produce covered by such contract is sold at public auction or on a warehouse floor, the warehouseman or purchaser shall not be liable for any damages, provided to be paid by any member in such contract, unless actual notice is given in writing before settlement that the tobacco sold or offered for sale belongs to a member of the association.

The State of Virginia has a law ${ }^{21}$ providing for the recording of contracts, which is similar to the South Carolina law quoted above.

Laws to regulate warehousemen and to cause them to record and disclose the true names of the owners of tobacco sold upon their auction floors have been enacted by the States of Virginia ${ }^{22}$ and South Carolina. ${ }^{23}$ These measures are said to have assisted the cooperative associations to check the practice of soliciting tobacco which association members were under contract to deliver to the association and selling it under assumed names on the auction floors.

\footnotetext{
19 'Tobacco Growers' Coop. Assn. v. Jones, 185 N. C. 265, 117 S. E. 174.

20 Acts and Joint Resolutions * * * of South Carolina, 1924, p. 1074.

21 Acts and Joint Resolutions * * * Virginia, 1924, p. 39.

22 Acts and Joint Resolutions * * * of Virginia, 1923, p. 129.

${ }^{23}$ Acts and Joint Resolutions * * * of South Carolina, 1924, p. 993.
} 


\section{Section 1 of the Virginia act states:}

Every person who shall deliver any leaf tobacco to a warehouseman or to a cooperative marketing association for sale, offer for sale or display for sale thereof, shall impart to such warehouseman or cooperative marketing association, the true name of the owner of said leaf tobacco; and it shall be the duty of such warehouseman or cooperative marketing association to keep a record of such purchase or delivery shewing the quantity of leaf tobacco so delivered, and said name of the owner thereof, given as provided herein.

The keeper of such records is required to permit inspection thereof and provision is made for penalty for violation of the act. This act was held constitutional in an opinion in which the Supreme Court of Virginia said:

The statute was adopted to prevent fraud, and, if there had been a universal custom of warehousemen to indulge in such subterfuges whereby frauds were promoted, then it is manifest that the occasion had arisen for the state to intervene to prevent them. It is said by the learned counsel for the warehousemen that it is "pertinent and proper for the court in this case to inquire into the true purpose of the act in question and ascertain whether it is a valid exercise of the police power of the state, or whether it is in reality 'an arbitrary interference with private business,' or whether it imposes 'unusual and unnecessary restrictions' upon a lawful occupation, or 'invades property rights.' " Responding to these inquiries we have no doubt whatever that it is a valid exercise of the police power; that it is not an arbitrary interference with private business; indeed the statute recognizes and accommodates itself to the customary methods of such business; namely, the identification of the specific piles of tobacco by the name of the true owner. That this invades no property rights is apparent. ${ }^{24}$

\section{MEMBERSHIP CONTRACTS}

As a prerequisite to membership in the association each applicant was required to sign a 5-year marketing contract in which he applied for membership. The contract ran from the member to the central organization with no intervening local organization. Membership was to be limited to actual growers of tobacco and landlords who received part of the crop as rent. Each member had one vote. Members were required to deliver all of their tobacco except that covered by a crop mortgage existing prior to joining, to the association at the place specified. Members were required to notify the association of any crop mortgage made after joining the association; the association retained the right to take delivery of the tobacco, and to pay off all or part of the crop mortgage for the account of the grower and to charge the amount paid against him individually.

The substance of the marketing agreement was as follows:

The association agreed to buy and the grower agreed to sell and deliver to the association all the tobacco produced by or for him or acquired by him as landlord or lessor, for the 5-year period named in the contract, no provision being made for withdrawal during the life of the contract.

Provision was made that all tobacco should be delivered at the earliest reasonable time, after it was picked or cured, to the order of the association, at the warehouse or plant controlled or specified by the association.

The association was authorized to commingle the tobacco of one grower with tobacco of a like type, grade, and quality of other growers, and to classify the tobacco delivered by its members, which classification was conclusive.

The association agreed to resell the tobacco which it received from its members at the best prices obtainable and to pay to the grower the net amount received, after deducting the costs of maintaining the association and of

${ }^{24}$ Reaves Warehouse Corporation $v$. Commonwealth and Motley et al. $v$. Same, 126 S. E. 87 . 
handling, grading, and marketing the tobacco and setting aside sufficient funds as reserve for credit and other purposes.

The association was authorized to deliver to any warehousing or other corporation organized for cooperation with the association any or all of the tobacco delivered by the grower, for handling, processing, manufacturing or storing.

The grower agreed to pay the association for all tobacco delivered, consigned, or marketed, or withheld by or for him, other than in accordance with the terms of the contract, the sum of 5 cents per pound as liquidated damages; and also agreed that in the event of a breach or threatened breach by him of any provision of the contract respecting delivery, the association was entitled to an injunction or to a decree of specific performance.

\section{CONTRACT VIOLATIONS PROSECUTED}

Although not a primary factor, the ironclad contract under which the member was obligated to deliver his crops to the association for five years, undoubtedly contributed to the dissatisfaction among the members. Marketing contracts are necessary in a cooperative enterprise handling a business of the nature and scope undertaken by the association, but most cooperatives now include a provision which permits a dissatisfied member to withdraw at certain periods during the life of the contract. The wisdom of this provision appears to be amply justified by experience. Certainly, dependence upon a legal tie to hold dissatisfied members in an association has been proved to be a mistaken policy. If a member's dissatisfaction is deep-seated, his own interests and those of the association are best served by the cancellation of his contract.

There was considerable complaint and criticism because the legal department is alleged to have brought suits for liquidated damages for nondelivery against tenants, insolvent farmers, and negroes, rather than against the larger, richer, and more influential contract violators. In this regard the agricultural investigating committee found that the policy was to bring suits against the larger growers as well as the smaller growers if conditions were such that there was a reasonable chance for the association to win. To prosecute a wealthy grower was more costly, and there was less chance of success. Any decision unfavorable to the association would redound greatly to the harm of the organization. The more intelligent violators were more resourceful in eluding their contracts by such methods as placing the farm or crop in the name of the tenant, or of the wife, or of some other member of the family, or disclaiming ownership of the tobacco by seemingly having rented the farms to other parties, and using other methods of evasion and subterfuge.

Early in the 1922 receiving season it was thought necessary to take drastic steps against members for violations of contract. It was hoped that if one or two members were held up as an example, other back-sliding members would be deterred from avoiding their obligations. From the outset the decisions of the courts were favorable to the association. Injunctions with or without liquidated damages, and orders for specific performance, were obtained in the lower courts against many members. Some of these cases were later carried to the supreme court on the grounds of constitutionality, but the supremecourt decisions also were in favor of the association.

During the first three years, 1,196 suits were brought against contract violators. By the end of 1924, 459 of these suits had been dis- 
posed of, and 737 were pending. Furthermore, 4,425 cases involving contract violation were settled out of court through the warehouse department during the first three years. In addition, 151 suits were brought by members and others against the association, most of which were decided in favor of the association.

The board of directors, in March, 1924, approved a policy of diplomatic persuasion and sympathetic leadership, instead of enforcing contracts by law and threats. Members of the board began to realize that the management should be open, frank, democratic, and grower-controlled, rather than secretive, centralized, and autocratic. The board, therefore, adopted a policy of publicity in regard to the conduct of all the affairs of the association except when secrecy was absolutely necessary to protect the business of the organization. By an extensive program of field service work, it hoped to keep in close contact with, and in the full confidence of, the individual members through individual calls, local meetings arranged by field men, and through warehousemen, graders, and local workers who would operate on a definitely planned and directed program of work. ${ }^{25}$

The board of directors in May, 1925, recognizing the fact that pending suits might deter the delivery of the 1925 crop, adopted the resolution that it would not withhold or deduct any sum of money from the proceeds of the 1925 tobacco for any claim or alleged breach of contract occurring prior to the opening of the 1925 delivery season.

But many facts and policies tended to cause the members to lose confidence in their organization. Attempts to compel landlords to deliver the unsigned tenants' share of the tobacco to the pool or to pay liquidated damages of 5 cents per pound for nondelivery; the policy of paying the creditor instead of the member for the lien against the latter's crop; putting the claim of the association ahead of recorded mortgages; promising settlements from time to time that were never made; the arbitrary change in grade standards on several markets during the 1923 receiving season; the lack of tact and knowledge on the part of warehousemen and graders; the failure to make payments at expected times. Local instances of extravagance and charges of dishonesty among the officials caused many of the less intelligent members especially to mistrust the cooperative. The association's policy of secrecy and the weakness and limitations of the field-service department resulted in lack of appreciation on the part of the members of the problems that confronted the officials and the board of directors.

Pressure of necessity and of creditors forced many would-be loyal members reluctantly to violate their contracts and to sell their tobacco under the auction system, although the prices prevailing on the auction floor were undoubtedly due, to some extent, to the existence of the farmers' organization. A member who had once broken his contract was very unlikely again to sell his product through the cooperative. He was more likely to become a critic of the organization and to justify his own disloyalty by attacking it.

In an effort to gain legal control over a major portion of the crop, all types of members were generally accepted regardless of their ability to fulfill their obligations. To induce the necessary number

${ }^{25}$ Minutes of board of directors, Mar. 18, 1924. 
of farmers to join the association, the benefits that would accrue to them as members from the operation of the association were presented in too favorable and positive a light. A large number of members who had delivered tobacco during the first years became dissatisfied because the improvement in their conditions which had been predicted during the organization campaign did not materialize.

In some districts, in 1922, members carried small quantities of their tobacco to the association warehouses merely to learn what the association would do. When the initial payment or grading was unsatisfactory these members often sold no more tobacco through the association.

Conditions were not improved in subsequent years by evidence and rumors of mismanagement, dishonesty, and mistaken policies, which were published and magnified by the opponents of the cooperativetobacco movement. Many of the steps taken by the association to improve the situation, such as the stringent enforcement of contracts, served to widen still further the breach between those members who had violated their contracts and the association, of which they were an integral part.

That many of the members were of the opinion that the policy of enforcing delivery of tobacco by legal procedure injured rather than helped the organization is shown in Table 17 . However, a fairly large percentage were of the opposite opinion, and believed that the association was helped by attempting to enforce the contracts. Many of these undoubtedly were merely expressing their wish to see the enforcement.

TABLE 17.-Replies to question, "Do you think the association's prosecution of contract violation hurt or helped the association?"

\begin{tabular}{|c|c|c|c|c|c|c|}
\hline \multirow[b]{2}{*}{ Reply } & \multicolumn{6}{|c|}{ Replies made by members of- } \\
\hline & $\begin{array}{c}\text { Sun-cured } \\
\text { pool }\end{array}$ & $\begin{array}{c}\text { Dark-fired } \\
\text { pool }\end{array}$ & $\begin{array}{l}\text { Old-belt } \\
\text { pool }\end{array}$ & $\begin{array}{c}\text { Eastern } \\
\text { Carolina } \\
\text { pool }\end{array}$ & $\begin{array}{l}\text { South } \\
\text { Carolins } \\
\text { pool }\end{array}$ & All pools \\
\hline $\begin{array}{l}\text { Hurt } \\
\text { Did not hurt association } \\
\text { Helped } \\
\text { Did not help association } \\
\text { Neither hurt nor helped. } \\
\text { Both hurt and helped } \\
\text { Don't know } \\
\text { Other replies } \\
\text { No reply }\end{array}$ & $\begin{array}{r}\text { Number } \\
13 \\
0 \\
14 \\
0 \\
0 \\
2 \\
1 \\
1 \\
0\end{array}$ & $\begin{array}{r}\text { Number } \\
37 \\
1 \\
22 \\
12 \\
12 \\
2 \\
14 \\
2 \\
0\end{array}$ & $\begin{array}{r}\text { Number } \\
92 \\
0 \\
28 \\
23 \\
8 \\
2 \\
39 \\
1 \\
2\end{array}$ & $\begin{array}{r}\text { Number } \\
186 \\
0 \\
16 \\
15 \\
2 \\
0 \\
32 \\
1 \\
2\end{array}$ & $\begin{array}{r}\text { Number } \\
81 \\
3 \\
32 \\
12 \\
4 \\
3 \\
25 \\
0 \\
1\end{array}$ & $\begin{array}{r}\text { Number } \\
309 \\
4 \\
112 \\
62 \\
26 \\
9 \\
111 \\
5 \\
5\end{array}$ \\
\hline Total .... & 31 & 102 & 195 & 154 & 161 & 643 \\
\hline
\end{tabular}

\section{ADVANCES AND PAYMENTS TO MEMBERS}

During the first year the association advanced only 40 per cent of the bankers' valuation of the tobacco delivered. The loaning banks at this time were making loans to the cooperative of 50 per cent of the amount of the appraised value of the tobacco. Of the appraised value, 40 per cent was used in making advances to the growers and 10 per cent was kept for association expenses. Later, the percentage of the loans was increased so that the initial advance 
payments were increased to 50 per cent of the bankers' valuation in 1923 and 1924 and to 65 per cent in 1925 .

The amounts of the payments of the eight pools for which final settlement was made for all grades averaged 95.5 per cent of the bankers' valuation. ${ }^{26}$ Table 18 shows the percentages of the bankers' valuation at which the pools had made payment up to the time of receivership. Two of the pools of the 1922 crop paid members amounts exceeding the bankers' valuation, and the average payments for the five pools, for the 1922 crop averaged 99.8 per cent. For the 1923 crop they were 86.1 per cent, and for the 1924 and 1925 crops they dropped to 62.3 per cent and 65.1 per cent, respectively. This decrease in percentage payments was due chiefly to the failure of the association to make sales and further payments beyond the initial advances.

TABLE 18.-Net cash paid to members for tobacco prior to receivership, in terms of percentages of the bankers' valuation, by crops and pools ${ }^{1}$

\begin{tabular}{|c|c|c|c|c|c|}
\hline Pool & $\begin{array}{l}1922 \\
\text { crop }\end{array}$ & $\begin{array}{l}1923 \\
\text { crop }\end{array}$ & $\begin{array}{l}1924 \\
\text { crop }\end{array}$ & $\begin{array}{l}1925 \\
\text { crop }\end{array}$ & $\begin{array}{l}\text { Weighted } \\
\text { average }\end{array}$ \\
\hline $\begin{array}{l}\text { Sun-cured } \\
\text { Dark-fired } \\
\text { Old belt } \\
\text { Eastern Carolina } \\
\text { South Carolina }\end{array}$ & $\begin{array}{r}83.6 \\
94.5 \\
100.7 \\
98.5 \\
105.2\end{array}$ & $\begin{array}{l}92.6 \\
82.8 \\
82.6 \\
90.7 \\
93.8\end{array}$ & $\begin{array}{l}89.5 \\
52.0 \\
63.6 \\
52.4 \\
76.2\end{array}$ & $\begin{array}{l}65.2 \\
65.1 \\
65.1 \\
65.1 \\
65.1\end{array}$ & $\begin{array}{l}82.7 \\
75.2 \\
83.8 \\
84.2 \\
85.4\end{array}$ \\
\hline Weighted average.. & 99.8 & 86.1 & 62.3 & 65.1 & 82.9 \\
\hline
\end{tabular}

1 For time and amounts of payments see appendix, Table 1.

Members in the South Carolina pool received for their four crops delivered to the association an average of 85.4 per cent of the bankers' valuation. The members of the eastern Carolina pool came next, with an average for the four crops of 84.2 per cent. Because of the failure of the association to sell more of their type of tobacco, the members of the pool for dark-fired tobacco received the least-75.2 per cent of the estimated value.

An average of the five pools for the four crops shows that, despite the fact that the association sold only 86.8 per cent of its total receipts of tobacco ${ }^{27}$ its actual sales amounted to 97.7 per cent of the bankers' valuation for all tobacco received and that the members received 82.9 per cent of the bankers' valuation of the tobacco delivered. They received 84.8 per cent of the amount of the sales price for all tobacco sold. The high percentage of amount of sales to total bankers' valuation is due in part to the fact that 53.5 per cent of the total tobacco sales (green basis) was tobacco which had been redried and thereby had its value enhanced. Figure 14 shows graphically the time and amount in terms of per cent of the bankers' valuation of each payment according to crop and pool.

Out of the 20 pools of tobacco, only 8 had been settled for in full when the association suspended operation. The pools on which final payments to members had been made are as follows: Sun-cured, all

23 Although final payments, resulting in overpayments, were made on the 1922 old-belt pool tobacco, all of the tobacco of this pool had not been sold at the time of receivership. (See Table 61 in the appendix.)

${ }_{27}$ Up to the time of the receivership. 


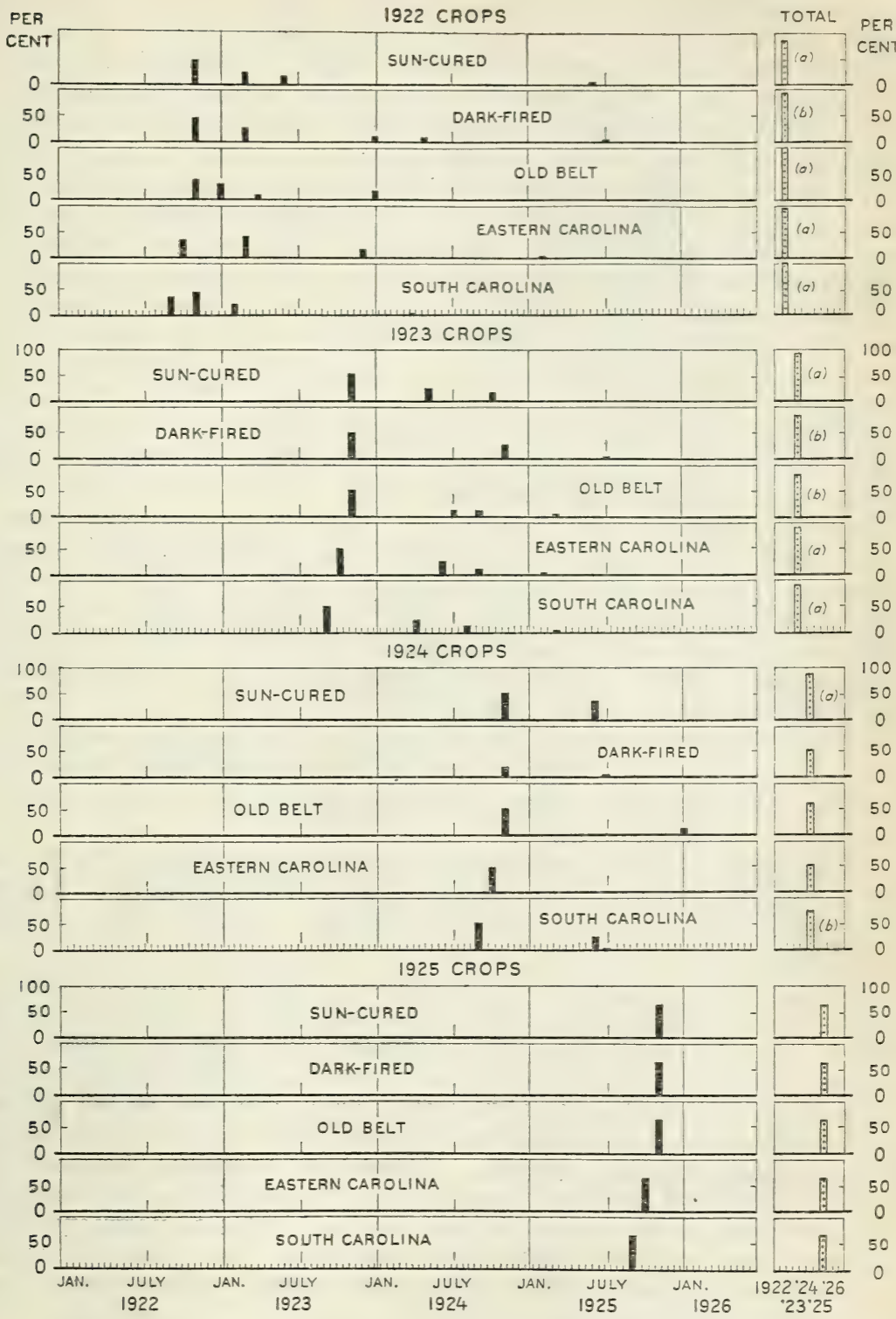

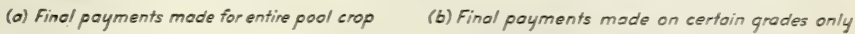

FIGURE 14.-PAYMENTS TO MEMBERS DURING:OPERATION OF ASSOCIATION, BY CROPS AND POOLS, 1922-1925 (IN TERMS OF BANKERS' VALUATION)

After the initial advances, the other payments were made at irregular intervals and in rarious amounts. 
grades of the 1922, 1923, and 1924 crops; eastern Carolina, all grades of the 1922 and 1923 crops; South Carolina, all grades of the 1922 and 1923 crops, and some grades of the 1924 crops; old belt, all grades of the 1922 crop and some of the grades of the 1923 crop (some of the 1922 tobacco was still on hand, however); and darkfired, some grades of the 1922 crop and some grades of the 1923 crop.

The pools for sun-cured tobacco were closed out for every crop except the 1925 crop, for which payment was soon to be made when the court granted the receivership. Of the 1924 pools, only for the sun-cured tobacco and some grades of the South Carolina pool had payment been made in full. No dark-fired or old-belt pools had been closed out; some of the grades of the 1922 and 1923 crops had been settled for in full; other grades had not yet been disposed of. Overpayments totaling $\$ 404,235.08$ were made to the members of three pool districts as follows: Old belt, $\$ 388,865.86$; eastern Carolina, $\$ 14,429.05$; South Carolina, $\$ 940.17 . .^{28}$ In order of the number of the different pools closed out or partially closed out the sun-cured is first; South Carolina, second; eastern Carolina, third; the old belt, fourth; and the dark-fired pool last.

Table 48 shows in more detail the payments to members in regard to the date and number of payments and percentage of bankers' valuation. In some cases four advance payments were made to members, plus a final payment when, and if, the pool was closed. In other cases pools were closed with only one or two advances and a final payment. Only the initial payment at the time of delivery had been made upon any of the 1925 pools.

For the first two crops it was the policy to make payments only when the entire pool, by year and belt, was closed out. Beginning with the 1924 crop, individual grades were settled for from time to time when completely sold.

Some of the payments to the members were as small as 2.39 per cent, 2 per cent, and even 0.77 per cent of the bankers' valuation. On the other hand, the payments after the delivery advances were as high as 43.9 per cent.

On an average, a period of 6.9 months elapsed from the time of delivery to the time of the second payment for all pools and for all years. The time of the third payment the time averaged 10.5 months, the fourth 15.7 months, and the fifth and final payment was made after 24 months. For the eight pools sold out for all grades, the average length of time that elapsed from the delivery to the final payment was 19.4 months. Although the period between the initial and second payments was shorter for the $1922 \mathrm{crop}$ than for any later crop, there seemed to be a tendency (due to payment when the grade was sold out rather than the entire pool) for the period to become shorter between other payments after the first year. Generally payments were made at shorter intervals in the sun-cured and old-belt pools than in the others.

After the initial advance, the delay in making further advances and final payments made it more difficult for some members to support the association. In justice to the officials of the association it should be pointed out that in the beginning, at least, every effort was

${ }^{28}$ Association andit report of May 31, 1925. 
made to make payments as promptly as possible. But the sale of tobacco under the conditions that came to prevail was a slow and difficult process. Under the most favorable circumstances several months must have elapsed before crops could have been disposed of and final settlements made. This condition would have automatically adjusted itself had the association continued in business long enough, and would have resulted in benefiting the growers by giving them money from time to time instead of all their yearly tobacco income at once. Withholding certain amounts, with payments spread over the season, would have made the producers more thrifty and less dependent upon the present system of crop financing so prevalent in that area. It is true, however, that many of the growers "would prefer $\$ 0.50$ to-day to $\$ 1$ a year from to-day," and this was one of the contributing factors to the failure of the members to deliver.

Evidence of the realization on the part of the officials of the need for prompt payments for members' tobacco (as well as evidence of inefficient management) was the overpayment of $\$ 104,235.08$ to members, chiefly of the old-belt pool, before all tobacco for which they were paid was sold. The tobacco failed to sell for a sum equal to the amount already sent to the members. The amount of the overpayments was then taken from the sales of tobacco of other members or from funds borrowed upon the pledging of the tobacco of all the members of the association. It was a common policy of the association to secure an estimate of the amount the tobacco would actually sell for, and to pay some pools on the basis of these estimates. This policy was the result of the pressure from some districts for prompt and frequent payments.

\section{OPERATING POLICIES AND PRACTICES}

It was in the formulation and execution of operating and sales policies that the most serious mistakes of the management were made. Some of these mistakes were inevitable and under less unfavorable conditions would not have permanently impaired the usefulness of the association. Others appear to have arisen from a division of interest and lack of experience on the part of some directors and employees, from inefficiency, and from lack of cooperation and coordination between certain departments. The employment of a full-time executive head would have been most helpful in the formulation and execution of the policies of the association and in the work of coordination, both as between departments and between the association as a whole and its members, patrons, and the public.

LACK OF COORDINATION WITHIN THE ASSOCIATION

Evidences of lack of coordination between departments were not difficult to find. That there should be such a lack of coordination under the circumstances was almost inevitable. The fact that two of the departments and the administrative office were located in Richmond, Va., and two departments in Raleigh, N. C., certainly did not lead to close cooperation. Many interviewed persons main- 
tained that this militated against the smooth working of the association. The fact that the administrative office was located in Richmond and that most of the salaried officials of the association were drawn from Virginia did not tend to aid in the best of coordination or of cooperation between the States, pools, and districts. On several occasions at least the field-service department published statements which were not strictly in accordance with facts. Officers of that department stated that it was difficult to obtain data from the head office. Data, when secured, were not always reliable. Officials of the head office maintained that statements were sometimes published on the basis of information obtained from other sources and without any request for information from another department.

Some of the employees submitted claims for such heavy expenses that they were disallowed by the auditor. This led to so much friction that the auditor was dismissed. It also happened that suggested improvements in records and methods were often delayed because heads of subdepartments would not admit that systems prepared by them could be improved. An unfortunate aspect of the situation was that records and forms were prepared frequently by one department which did not fit the requirements of another department. After great expense in printing had been incurred, such record forms often had to be discarded.

An outstanding case illustrating this point came to notice during the course of the study of the records of the association. Certain forms were drawn up by the head of a subdepartment and were printed at a cost of over $\$ 3,000$. Before one book of the forms had been used it was found that they did not meet requirements, and their use was abandoned. In other cases sufficient forms and record sheets to last for twice the period of the contracts of the members were printed. Such expenses were practically inevitable when there was a lack of close contact between departments and individuals.

SELECTION OF PERSONNEL

One of the first problems that confronted the organizers of the Tobacco Growers Cooperative Association in 1922 was to set up, before July of that year, a business organization adequate to handle the anticipated delivery of about $300,000,000$ pounds of tobacco. Selection and hiring of the desired personnel constituted the greater part of this work. Most of the detailed work of obtaining suitable managers and personnel for the different departments was delegated by the board of directors to the executive committee. Great difficulty was encountered in obtaining the services of suitable managers for the various departments. It was necessary that men with an intimate knowledge of tobacco and of the tobacco trade be selected for these positions. Owing to the growing opposition to the association and to the uncertainty of its ultimate success, men who had proved capable in the tobacco trade were loath to relinquish their positions. It did prove possible, however, to obtain some men who had made good in the tobacco trade and whose ability and services seemed valuable to the association. 
The men selected were probably the best available at the salaries that the association officials wished to pay. To secure them promptly and to induce them to leave old positions for positions in a new and none too reliable venture required the offer of a substantial increase in salary over that which they had been receiving. Good salaries had to be paid to secure men qualified for their tasks. Men who were well known in the tobacco field were approached as possible officials of the association. Some of these men refused on the basis that the salaries offered were not sufficient to induce them to leave the positions they then held.

In frequent instances when a warehouse was purchased or leased by the association its former operator or owner was hired as its association manager. In this way some experienced warehouse managers were secured and with them their former employees and many of their former patrons as members of the new organization. Many of the private warehousemen made good managers. Others who were not sincere believers in the cooperative movement merely took the positions offered them as the safest move in the belief that operating private warehouses would be unprofitable because of the existence of the cooperative. When they learned that the salary given was not equal to their earnings as private operators and that the farmers' organization was not proving as successful as had been anticipated, many of them became antagonistic to the interests of the association and directly or indirectly aided in its downfall.

Some of these warehouse managers had been disliked and mistrusted as private operators. Many members felt that farmer members should have the warehouse positions. To leave the positions in the same hands did not please the farmers, as they felt that these men were still in the control of the large tobacco companies and that they did not represent the new method of marketing tobacco.

Evidence of the attitude of the members in some localities toward the association warehousemen is found in the report of the Agricultural Investigating Committee. Quoting from the report:

The committee finds that there is no doubt of the existence of very pronounced discontent, bordering almost on rerolt, on the part of certain localities because of their feeling that warehouse officials are incompetent. The committee did not attempt to prove or disprove these accusations of the growers, but it does have absolute evidence of the existence of this state of mind on the part of large blocks of growers in specific areas, and it does have eviclence that many growers in these areas state that delireries for 1925 will be materially reduced if their criticisms are not listened to.

Table 19 shows the number of members by pools who objected, and the numbers who did not object, to the local warehousemen, as found by the membership study.

About 20 per cent of the members visited objected to the local warehouseman of the association. Their chief objection to him, however, was in regard to the salary he received, and did not refer to his ability, personality, or honesty. The second most frequent criticism was that the manager was incapable. Most of the criticisms of the warehouseman were probably due to the failure of the association to meet the members' demands and expectations and were not really criticisms of the warehouseman as an individual. 
TABLE 19.-Replies to question, "Did you have any objection to your local association warehouse manager?"

\begin{tabular}{|c|c|c|c|c|c|c|}
\hline \multirow[b]{2}{*}{ Reply } & \multicolumn{6}{|c|}{ Replies from members of- } \\
\hline & $\begin{array}{c}\text { Sun-cured } \\
\text { pool }\end{array}$ & $\begin{array}{c}\text { Dark-fired } \\
\text { pool }\end{array}$ & $\begin{array}{c}\text { Old-belt } \\
\text { pool }\end{array}$ & $\begin{array}{c}\text { Eastern } \\
\text { Carolina } \\
\text { pool }\end{array}$ & $\begin{array}{l}\text { South } \\
\text { Carolina } \\
\text { pool }\end{array}$ & All pools \\
\hline Yes... & Number & Number & $\begin{array}{r}\text { Number } \\
38\end{array}$ & $\begin{array}{r}\text { Number } \\
18\end{array}$ & $\begin{array}{r}\text { Number } \\
26\end{array}$ & $\begin{array}{r}\text { Number } \\
128\end{array}$ \\
\hline Other replies & $\begin{array}{r}10 \\
1\end{array}$ & $\begin{array}{r}76 \\
0\end{array}$ & $\begin{array}{r}156 \\
1\end{array}$ & $\begin{array}{r}132 \\
4\end{array}$ & $\begin{array}{r}133 \\
2\end{array}$ & $\begin{array}{rl}507 & 8 \\
8 & -1\end{array}$ \\
\hline
\end{tabular}

It does appear, however, that some of the warehousemen lacked the tact, knowledge, and ability to be the local leaders, contact men, and representatives of the association and to render competent service to the members. Some were temperamentally unfitted to listen sympathetically, courteously, or patiently to the questions and wishes of the members. In certain sections, the warehouse managers antagonized the farmers by their independent and unhelpful attitude. The failure of the warehousemen to give full information in regard to salaries and other affairs of the association created a feeling of mistrust and dislike, and even led farmers to question the honesty and competence of the warehouse managers.

\section{SALARIES OF EMPLOYEES}

Much criticism has been directed against the association on account of the salaries it paid or was supposed to be paying to its officials and employees. Table 20 gives the average salaries monthly for some of the employees as given by the records of the association and reports of the receivers and of the Agricultural Investigating Committee.

TABLE 20.-Average monthly salaries paid association officials and employees

\begin{tabular}{|c|c|c|c|c|}
\hline Position & 1922 & 1923 & 1924 & 1925 \\
\hline Executive & Dollars & Dollars & $\begin{array}{l}\text { Dollars } \\
1772,48\end{array}$ & $\begin{array}{l}\text { Dollars } \\
1567.29\end{array}$ \\
\hline Warehouseman. & $\begin{array}{r}1,224.85 \\
2367.67\end{array}$ & 2254.36 & 192.53 & $1.00 \% .28$ \\
\hline Grader..... & 275.33 & 2271.03 & 3255.06 & -......... \\
\hline Clerk. & 2135.43 & ${ }^{2} 131.73$ & & -...-n. \\
\hline Field-service man. & 295.59 & 218.75 & 164.64 & - - \\
\hline District warehouse manager & ............ & ................. & 3694.45 & - n- \\
\hline Supervising grader & - & 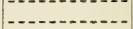 & 3 589.81 & - \\
\hline Legal department & 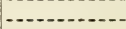 & 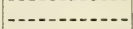 & ${ }^{8} 288.33$ & - \\
\hline
\end{tabular}

1 Receivers' Report, 1928. Minutes, June, 1924; data for June, 1924.

The salaries paid to the executive officers have been subjected to a great deal of criticism. Table 21 shows the amounts paid as salaries to officers of the association during the period February 8, 1922, to June 19, 1926, by fiscal years. In 1922-23 and 1923-24 six officials were employed at salaries ranging from $\$ 12,000$ to $\$ 45,000$ per year, aggregating $\$ 163,999.98$ in $1922-23$ and $\$ 135,333.33$ in 1923-24. One official, whose salary was $\$ 25,000$, resigned, and another, whose salary was $\$ 40,000$, died in 1923 . These positions were not filled. In 1924-25 every official whose salary was over $\$ 10,000$ voluntarily submitted to a reduction of salary, so that in 1924-25 there were four officials drawing salaries from $\$ 11,000$ to $\$ 26,000$, which totaled 
$\$ 72,333.24$. In $1925-26$ most of these officers accepted further reductions in salary. The totals show a marked downward trend from 1922-23 to $1925-26$.

In regard to employing officers for the association, the minutes of the board of directors of March 14, 1922, state:

The point was made during the discussion thit it was necessary to secure outstanding and big men as the principal officers of the corporation and that these men should be secured for whiterer salary it was necessary to pay. Every member of the board expressed himself as being in faror of this point.

In a letter to the executive committee on October 10, 1922, the director of the warehouse department showed the comparative difficulty of securing employees in the different districts where the degree of sentiment for and against the association varied. It follows, in part:

I would like also to call your attention to the fact that the salaries in Virginia and Central Carolina are less per month than in the other belts. The reason, of course, is that we had a very poor sign-up in eastern Carolina and South Carolina and concessions had to be made in the employment of men. They did not have to be made where we had a strong sign-up.

TABLE 21.-Salaries paid officials of the Tobacco Growers' Cooperative Associution, February 8, 1922-June 19, 1926, by fiscal years

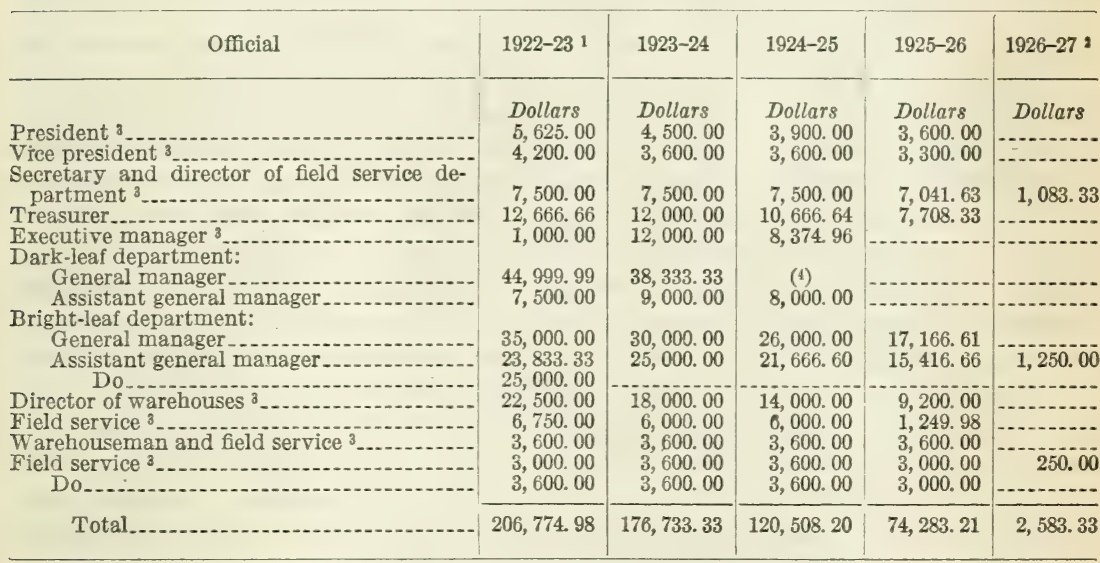

1 Sixteen months. Fiscal years extended from June 1 to May 31, but in this table the period Feb. 8, 1922 , to May 31, 1923, was considered as one fiscal year.

2 Nineteen days.

3 Member of board of directors.

4 Deceased.

It was necessary to employ a large number of persons for clerical work, common labor, and other duties in the head office, the fieldservice department, and the warehouse department. According to the pay rolls of the association in October, 1922, the 1,006 regular employees of the association, exclusive of 16 employees in the executive office, were distributed as is shown in Table 22 .

By closing some warehouses, consolidating tasks, and eliminating unnecessary workers, the number of employees decreased every year until in $1925-26$ it was 598 , about 60 per cent of the 1922-23 number.

During the first year it was the policy of the warehouse department to use five men in each warehouse-exclusive of the tobacco handlers and laborers. One of these five was to be the warehouse 
manager, one the floor manager, and the other three were to be clerical men. The warehouse managers were hired by the year, as was the head bookkeeper in some instances. The assistant managers and the clerical men were usually hired for a number of months. As the season closed in one district, some of the employees could sometimes be transferred to another district. There was considerable objection to the district warehouse managers because, in the minds of some of the members at least, they performed no definite service for the association and received very high salaries. Most of the receiving warehouses were open for only a few months of each year. During the closed season the warehouse manager as well as some of the employees of the leaf department assisted with membership or other field-service work. The warehouse managers were on a yearly salary basis and had very few regular duties for long periods each year; this fact caused later criticism on the part of the farmers.

The average annual salary paid to 83 warehousemen in the warehouse department in 1922 was over $\$ 4,400$; in 1923 the annual salary of 114 warehousemen was over $\$ 3,000$.

There was some criticism of the salaries paid to many of the employees of the leaf department. The detailed records of salaries paid to the officers of this department could not be traced in the files of the association, but from a statement made by the association to the agricultural investigation committee it would appear that, in 1922, 111 graders were employed at an average annual salary of $\$ 3,300$, and in 1923, 124 were employed at an annual average salary of $\$ 3,250$. According to the minutes of the board of directors of June 3, 1924, the district managers of the warehouse department were receiving an average of $\$ 694.45$ a month at that time, and the graders $\$ 255.06$ a month. Several of the supervising graders undoubtedly were paid high salaries, but the association was forced to pay high salaries if it wished to retain the services of capable men. It is probable that there was a tendency toward payment of salaries somewhat more liberal than conditions warranted, but it must be realized that from the beginning the ultimate success of the association was in doubt, and these graders were not willing to take positions with the association unless the remuneration was sufficiently attractive to compensate for the risk incurred.

Table 22 gives the number of employees within different salary ranges by years, departments, and totals, as far as the data are available.

The turnover in the personnel of the warehouse division was pronounced; 255 men employed in the warehouse department in 1922 were not rehired in 1923. The officials of the warehouse department attribute this to three causes: The elimination of men not entirely loyal to the association; the closing of some of the warehouses; and the need of fewer men to handle the same volume of tobacco under the cooperative marketing system than under the auction floor system. ${ }^{29}$

28 Report of A'gricultural Investigating Committee, 1925. 
TABLE 22.-Number of employees receiving indicated salaries each fiscal year, zy departments

\begin{tabular}{l|l|l} 
Field service department & Head office & Warehouse department
\end{tabular}

Annual salary 1922-23 1923-24 1924-25 1925-26 1922-23 1923-24 1924-25 1:25-26 1922-23 16:23-24 1924-25 1925-26

\begin{tabular}{|c|c|c|c|c|c|c|c|c|c|c|c|c|}
\hline $\begin{array}{l}\text { Under } \$ 999 \ldots . . . \\
\$ 1,000-\$ 1,999 \ldots \\
\$ 2,000-\$ 2,999 \ldots \\
\$ 3,000-\$ 3,999 \ldots \\
\$ 4,000-\$ 4,999 \ldots \\
\$ 5,000 \text { and over. }\end{array}$ & $\begin{array}{r}9 \\
14 \\
24 \\
24 \\
5 \\
1\end{array}$ & $\begin{array}{r}5 \\
16 \\
7 \\
5 \\
3 \\
2\end{array}$ & $\begin{array}{l}9 \\
8 \\
7 \\
3 \\
4 \\
2\end{array}$ & $\begin{array}{r}4 \\
35 \\
45 \\
20 \\
8 \\
1\end{array}$ & $\begin{array}{r}104 \\
75 \\
6 \\
4 \\
0 \\
0\end{array}$ & $\begin{array}{r}60 \\
70 \\
10 \\
6 \\
5 \\
0\end{array}$ & $\begin{array}{r}56 \\
66 \\
18 \\
6 \\
1 \\
1\end{array}$ & $\begin{array}{r}51 \\
72 \\
21 \\
6 \\
3 \\
0\end{array}$ & $\begin{array}{r}17 \\
30 y \\
181 \\
47 \\
31 \\
9\end{array}$ & $\begin{array}{r}13 \\
300 \\
157 \\
30 \\
19 \\
8\end{array}$ & $\begin{array}{r}13 \\
154 \\
199 \\
33 \\
15 \\
9\end{array}$ & $\begin{array}{r}12 \\
80 \\
124 \\
10 \\
3 \\
6\end{array}$ \\
\hline Total.... & 77 & 38 & 33 & 113 & 189 & 151 & 148 & 153 & 594 & 527 & 423 & 235 \\
\hline
\end{tabular}

\begin{tabular}{|c|c|c|c|c|c|c|c|c|}
\hline \multirow[b]{2}{*}{$\begin{array}{l}\text { Under } \$ 999 \ldots \\
\$ 1,000-\$ 1,999 \\
\$ 2,000-\$ 2,999\end{array}$} & \multicolumn{4}{|c|}{ Leaf department } & \multicolumn{4}{|c|}{ Totals } \\
\hline & $\begin{array}{r}0 \\
29 \\
39 \\
50 \\
12 \\
16\end{array}$ & $\begin{array}{r}0 \\
8 \\
34 \\
43 \\
14 \\
17\end{array}$ & $\begin{array}{r}0 \\
7 \\
35 \\
45 \\
12 \\
17\end{array}$ & $\begin{array}{r}0 \\
3 \\
38 \\
39 \\
9 \\
8\end{array}$ & $\begin{array}{r}130 \\
427 \\
250 \\
125 \\
48 \\
26\end{array}$ & $\begin{array}{r}78 \\
394 \\
208 \\
84 \\
41 \\
27\end{array}$ & $\begin{array}{r}78 \\
235 \\
259 \\
87 \\
32 \\
29\end{array}$ & $\begin{array}{r}67 \\
190 \\
228 \\
75 \\
23 \\
15\end{array}$ \\
\hline Total & 146 & 116 & 116 & 97 & 1,006 & 832 & 720 & 598 \\
\hline
\end{tabular}

1 Includes 23 temporary employees.

The number of warehousemen used at first (fire for each warehouse) proved excessive and occasioned complaint from the members. The positions of warehouse manager and grader were later consolidated. By the closing of receiving points, and the consolidation of positions, the number of regular warehouse department employees was decreased from 594 in 1922-23 to 235 in 1925-26. (Table 22.)

In the membership study the two criticisms of the association most frequently given by the members were "too high salaries" and "extravagance." In regard to the salaries paid by the association, 484 criticized them, and 47 more criticized them with qualifications, such as "those of the higher officials," "those of the warehousemen," "of certain individuals," etc.; 78 member's made no criticism of the salaries. (Table 23.)

TABLE 23.-Replies to question, "Do you have any criticisms regarding the salaries paid by the association?"

\begin{tabular}{|c|c|c|c|c|c|c|}
\hline \multirow[b]{2}{*}{ Reply } & \multicolumn{6}{|c|}{ Replies from members of- } \\
\hline & $\begin{array}{l}\text { Sun-cured } \\
\text { pool }\end{array}$ & $\begin{array}{l}\text { Dark-fired } \\
\text { pool }\end{array}$ & $\begin{array}{l}\text { Old-belt } \\
\text { pool }\end{array}$ & $\begin{array}{c}\text { Eastern } \\
\text { Carolina } \\
\text { pool }\end{array}$ & $\begin{array}{l}\text { South } \\
\text { Carolina } \\
\text { pool }\end{array}$ & All pools \\
\hline 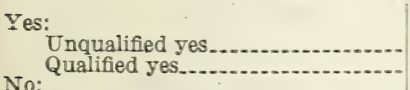 & $\begin{array}{r}\text { Number } \\
10 \\
14\end{array}$ & $\begin{array}{r}\text { Number } \\
69 \\
18\end{array}$ & $\begin{array}{r}\text { Number } \\
171 \\
4\end{array}$ & $\begin{array}{r}\text { Number } \\
123 \\
4\end{array}$ & $\begin{array}{r}\text { Number } \\
111 \\
7\end{array}$ & $\begin{array}{r}\text { Number } \\
484 \\
47\end{array}$ \\
\hline 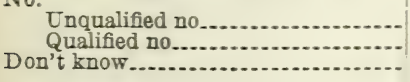 & $\begin{array}{l}4 \\
0 \\
3\end{array}$ & $\begin{array}{r}13 \\
0 \\
2\end{array}$ & $\begin{array}{r}13 \\
0 \\
7\end{array}$ & $\begin{array}{r}14 \\
0 \\
13 \\
\end{array}$ & $\begin{array}{r}34 \\
1 \\
8 \\
\end{array}$ & $\begin{array}{r}78 \\
1 \\
33 \\
\end{array}$ \\
\hline Total ... & 31 & 102 & 195 & 154 & 161 & 643 \\
\hline
\end{tabular}

To learn the cause of the criticisms of salaries, the question was asked of the members, "Is your criticism of these salaries due to 
the salaries themselves, to the type of ability employed at these salaries, to both, or to what other reasons?" About an equal number, 102 and 105 (Table 24) replied that their criticism was due to the salaries themselves and to the type of ability hired at these salaries. A large number felt that some of the salaries were too high and others stated that the salaries of the higher officials were too high.

There was considerable criticism of the association for its so-called policy of secrecy in not making public the salaries of individuals employed by the cooperative. Until recommendations were made by the agricultural investigating committee in 1925, it was the policy of the association to refrain from making public the salaries of its officials and employees. The officials were bound in their contracts not to divulge their salaries even to their fellow employees. It was felt that the farmers, being accustomed to a small cash income themselves, would not be able to realize the necessity for the payment of high salaries to the officers of their association.

During the membership study, in answer to the question: "Do you feel that you were kept as well informed on policies and details of the association as you should have been?" Four hundred and sixtyfour or 72 per cent of the members interviewed replied, "No"; 107 answered "Yes"; 64 were doubtful or did not know. (Table 25.)

TABLE 24.-Replics to question, "Is your criticism of these salaries due to the salaries themselves, to the type of ability employed at these salaries, both, o: to what other reasons?" 1

\begin{tabular}{|c|c|c|c|c|c|c|}
\hline \multirow[b]{2}{*}{ Reply } & \multicolumn{6}{|c|}{ Replies from members of- } \\
\hline & $\begin{array}{c}\text { Sun-cured } \\
\text { pool }\end{array}$ & $\begin{array}{l}\text { Dark-fired } \\
\text { pool }\end{array}$ & $\begin{array}{l}\text { Old-belt } \\
\text { pool }\end{array}$ & $\begin{array}{c}\text { Eastern } \\
\text { Carolina } \\
\text { pool }\end{array}$ & $\begin{array}{l}\text { South } \\
\text { Carolina } \\
\text { pool }\end{array}$ & All pools \\
\hline $\begin{array}{l}\text { Due to type of ability } \\
\text { Due to salaries themselves. } \\
\text { All too high } \\
\text { Some too high } \\
\text { Higher officials paid too much } \\
\text { Both ability and amount of salary } \\
\text { Don't know } \\
\text { Other replies..... }\end{array}$ & $\begin{array}{r}\text { Number } \\
11 \\
4 \\
2 \\
1 \\
0 \\
4 \\
5 \\
2\end{array}$ & $\begin{array}{r}\text { Number } \\
29 \\
31 \\
0 \\
10 \\
2 \\
14 \\
1 \\
5 \\
\end{array}$ & $\begin{array}{r}\text { Number } \\
44 \\
47 \\
23 \\
52 \\
19 \\
6 \\
2 \\
17\end{array}$ & $\begin{array}{r}\text { Number } \\
6 \\
4 \\
42 \\
56 \\
13 \\
0 \\
8 \\
11 \\
\end{array}$ & $\begin{array}{r}\text { Number } \\
15 \\
16 \\
21 \\
48 \\
7 \\
0 \\
10 \\
12 \\
\end{array}$ & $\begin{array}{r}\text { Number } \\
105 \\
102 \\
88 \\
167 \\
41 \\
24 \\
26 \\
47 \\
\end{array}$ \\
\hline Total ... & 29 & 92 & 210 & 140 & 129 & $\overrightarrow{600}$ \\
\hline
\end{tabular}

1 Asked of the 531 members who said they had criticisms of salaries; some gave more than 1 typical reply

TABLE 25.-Replies to question, "Do you feel that you were kept as well informed on policies and details of association as you should have been?"

\begin{tabular}{|c|c|c|c|c|c|c|}
\hline \multirow[b]{2}{*}{ Reply } & \multicolumn{6}{|c|}{ Replies from members of- } \\
\hline & $\begin{array}{l}\text { Sun-cured } \\
\text { pool }\end{array}$ & $\begin{array}{l}\text { Dark-fired } \\
\text { pool }\end{array}$ & $\begin{array}{l}\text { Old-belt } \\
\text { pool }\end{array}$ & $\begin{array}{c}\text { Eastern } \\
\text { Carolina } \\
\text { pool }\end{array}$ & $\begin{array}{c}\text { South } \\
\text { Carolina } \\
\text { pool }\end{array}$ & $\begin{array}{c}\text { All } \\
\text { pools }\end{array}$ \\
\hline $\begin{array}{l}\text { Nos } \\
\text { Don't know or doubtfull } \\
\text { Other answers. }\end{array}$ & $\begin{array}{r}\text { Number } \\
20 \\
10 \\
1\end{array}$ & $\begin{array}{r}\text { Number } \\
73 \\
19 \\
9 \\
1\end{array}$ & $\begin{array}{r}\text { Number } \\
161 \\
19 \\
13 \\
2\end{array}$ & $\begin{array}{r}\text { Number } \\
92 \\
28 \\
31 \\
3\end{array}$ & $\begin{array}{r}\text { Number } \\
118 \\
31 \\
10 \\
2\end{array}$ & $\begin{array}{r}\text { Number } \\
464 \\
107 \\
64 \\
8\end{array}$ \\
\hline Total... & 31 & 102 & 195 & 154 & 161 & 643 \\
\hline
\end{tabular}


Secrecy of the association in regard to salaries created wild rumors and aroused suspicion regarding the supposedly excessive salaries of directors, officials, and employees. No doubt persons opposed to the farmers' organization were the source of many of these rumors and exaggerations.

Unquestionably the publishing of individual salaries of the employees would result in some jealousy and discontent among those employed. This could have been avoided and all suspicion could have been allayed by making public, from time to time, the salaries of each of the higher officials, but only the average salaries of groups of employees as graders, warehouse managers, and clerks.

OWNERSHIP OF WAREHOUSE PROPERTY

In marketing tobacco the receiving warehouse is the place of assembly. As soon as the marketing season began it was necessary for the association subsidiaries to open warehouses in each of the districts. It would have been better if the association could have operated these warehouses. This, however, was impossible because it was necessary to create other corporate bodies in order that warehouse receipts could be issued and used as collateral for loans. To effect this, the tri-State tobacco area was divided into five districts, and five warehousing corporations were formed. (Fig. 10.)

The marketing contract of the Tobacco Growers' Cooperative Association provided that a warehousing or other corporation might be organized in any district or community where at least 100 members signed a petition for the formation of such an organization. The business to be conducted by this corporation was to receive and store agricultural products as a public warehouseman; to lease, acquire, purchase, or construct receiving plants, warehouses, drying plants, or other buildings necessary or convenient for the purpose of receiving, drying, curing, processing, conditioning, preserving, grading, packing, storing, manufacturing, and handling tobacco, or any of these, and to carry on any of such activities. ${ }^{30}$

These corporations were to run on a nonprofit basis and were to be financed by deductions from the marketing proceeds of the members' tobacco within the respective districts in which the warehouses were operated. If, however, any central plants were purchased, leased, or constructed, or operated for the general benefit of several or all districts, such deductions would be made from the proceeds of all districts benefited. Table 26 shows the deductions made from the marketing proceeds and applied to the purchase of warehouse property.

TABLE 26.-Deductions from marketing proceeds applied to the purchase of warehouse property, by warehousing corporations

\begin{tabular}{|c|c|c|c|c|}
\hline Warehousing corporation & 1922 & 1923 & 1924 & 3 crops a \\
\hline $\begin{array}{l}\text { Dark-leaf } \\
\text { Bright-leaf } \\
\text { Central Carolina } \\
\text { Eastern Carolina } \\
\text { South Carolina }\end{array}$ & \begin{tabular}{r}
\multicolumn{1}{c}{ Dollars } \\
$25,564.10$ \\
$108,230.63$ \\
$102,452.02$ \\
$219,599.23$ \\
$87,639.64$
\end{tabular} & $\begin{array}{l}\text { Dollars } \\
19,257.17 \\
72,876.37 \\
63,353.86 \\
247,818.38 \\
100,271.49\end{array}$ & \begin{tabular}{l}
\multicolumn{1}{l}{ Dollars } \\
$13,428.95$ \\
$52,151.71$ \\
$46,828.85$ \\
$14,683.54$ \\
$8,526.05$
\end{tabular} & $\begin{array}{l}\text { Dollars } \\
58,250.22 \\
233,258.71 \\
212,634.73 \\
482,101.15 \\
196,437.18\end{array}$ \\
\hline Total_. & $543,485.62$ & $503,577.27$ & $135,619.10$ & $1,182,681.99$ \\
\hline
\end{tabular}

- No deductions were made from the 1925 crop.

30 Declaration of charter and articles of incorporation of warehousing corporation. 
The plan followed by the association was to make the demanded cash payment for the warehouse and to pay the balance by the issue of serial income bonds and preferred stocks, and to retire one-fifth of the preferred stock each year. To sell the bonds and preferred stock, the association guaranteed the payment and retirement of the preferred stock within five years. To meet these payments the contract between the association and the growers provided that not more than 1 per cent of the proceeds from the sale of tobacco should be deducted for commercial credit and general purposes. The money derived from this source was used to retire the stocks and bonds. ${ }^{31}$

Only 11 shares of common stock with a par value of $\$ 10$ per share were originally authorized, of which no member could originally purchase more than 1 share. The common capital stock was to be increased from time to time in such amounts as would equal one class of the preferred stock. The preferred stock was retired as the corporation issued common capital stock in an equivalent amount. 'The common stock was issued to members as soon as the aggregate deductions from their tobacco sales were equal to the volume of one or more shares. Only members could purchase or have issued to them the common stock which had all of the voting power of the corporation, but no restriction was placed upon the sale of preferred stock, which was to bear 7 or 8 per cent cumulative dividends. The common stock was to receive dividends up to but not exceeding 8 per cent.

The warehouses purchased became the property of the different warehouse corporations, which also acquired control by lease over other warehouses used by the association. Each warehousing corporation had its own board of directors and was incorporated for 20 years.

The corporations were bound to the parent association by a cross contract which provided that the Tobacco Growers' Cooperative Association should undertake to pay all the expenses of operation, and dividends and payments on the preferred stock and bonds as they fell due, in return for the use of the property, and that the warehousing corporations be operated on a nonprofit basis. ${ }^{32}$ The nature of the relationship was virtually as follows: The tangible property was in the hands of the various corporations, whereas the operation of the warehouse was in the hands of the association warehouse department, one of the main departments of the parent association.

31 In an agreement between the various warehousing corporations and the Tobacco Growers' Cooperative Association, the association had guaranteed the redemption or retirement of the preferred capital stock and the serial income bonds of the warehousing corporations, together with the dividends and interest thereon. At a meeting of the board of directors on September 18, 1924, a plan was adopted whereby there would be withheld from the proceeds of the sales of each year's crop, an amount sufficient to retire one class of preferied capital stock, plus one year's dividends on all classes of stock issued or to be issued.

32 Paragraph $16(g)$ of the association agreement. The association shall make a cross contract with the corporation, providing substantially as follows: That the corporation shall handle, process, dry, cure, condition, manufacture, treat, store, ship, and deliver all as required and directed by the association, the tobacco delivered to it by and at the order of the association. Such service will be on a nonprofit basis; and the corporation shall receive therefor only the actual costs of such operations and amounts, apportioned over the operation of any one season, sufficient to pay a dividend of 8 per cent on the outstanding common stock and the dividends on the outstanding preferred stock and to retire each of the five calendar years, beginning with 1923 , one-fifth of the preferred stock, or one class thereof; and sufficient amounts for taxes, insurance, depreciation, betterments, and commercial and secondary charges, all as the directors of the association may instruct and limit the corporation, and not otherwise. 
The warehouse corporations were to do no buying or selling of tobacco whatsoever.

PURCHASE OF WAREHOUSES AND WAREHOUSING POLICIES

It was necessary before the marketing season opened to obtain control of local warehouses to handle anticipated deliveries of tobacco. A warehousing department was formed and placed under the control of a director of warehouses, with a staff consisting of an assistant director and several district directors. The board

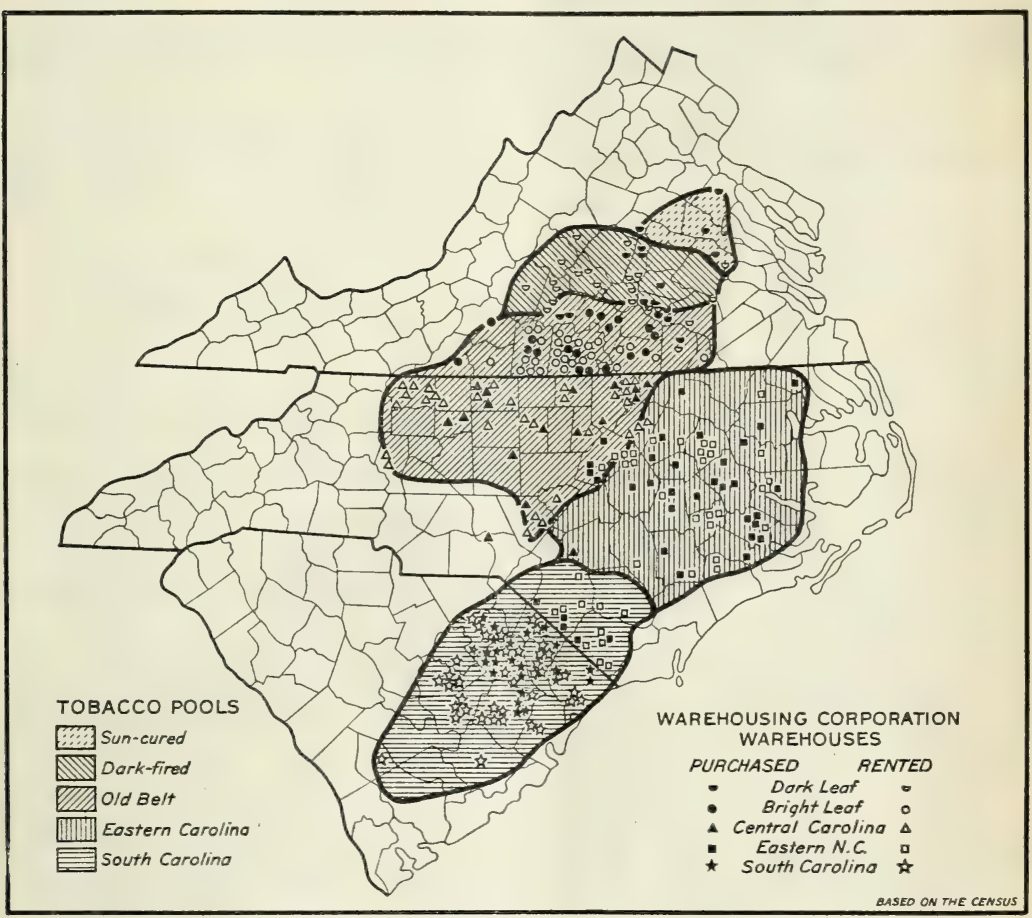

FIGURE 15.-LOCATION AND NUMBER OF ASSOCIATION WAREHOUSES BY WAREHOUSING CORPORATIONS AND POOL AREAS, 1923

In 1923 the tobacco association owned 115 warehouses and rented 116 . It operated more than one warehouse in each of 72 out of 149 markets where it had warehouses. In 44 markets it had 2 warehouses, in 22 it had 3 , and in 6 markets it had 4 warehouses.

placed upon this director and a subcommittee of the board the task of purchasing or leasing the necessary warehouse space. By June 17,1922 , the association was able to report the acquisition, by purchase, lease, or contract to build, of 214 warehouses located in the important receiving centers. The tangible warehouse property came under the control of five subsidiary warehousing corporations. Figure 15 shows the location of the five warehousing corporations and the distribution of the purchased and leased warehouse property.

Table 27 gives the number of tobacco warehouses owned, leased, and controlled by warehousing corporations, by years. The total 
number decreased from 232 in 1922 to 206 in 1926 . Due to destruction by fire and expiration or cancellation of the contract the number of leased warehouses decreased from 120 in 1922 to 90 in 1926. Table 28 shows the number of warehouses leased and relinquished, by years, and warehousing corporations. During the period of operation of the association 70 warehouses were relinquished and 160 leased. The Bright Leaf Warehousing Corporation was the only one of the five corporations after 1922 to lease more warehouses than it relinquished. Of the total 70 cessations, 32 were due to expiration of contract, 30 due to cancellation of contract, and 8 due to destruction of the warehouse.

TABLE 27.-Number of warchouses controlled by warehousing corporations, 1922-1926

\begin{tabular}{|c|c|c|c|c|c|}
\hline Warehousing corporation and form of control & $\begin{array}{c}\text { Dec. 31, } \\
1922\end{array}$ & $\begin{array}{c}\text { Dec. 31, } \\
1923\end{array}$ & $\begin{array}{c}\text { Dec. } 31, \\
1924\end{array}$ & $\begin{array}{c}\text { Dec. } 31, \\
1925\end{array}$ & $\begin{array}{c}\text { June } 1, \\
1926\end{array}$ \\
\hline $\begin{array}{l}\text { Dark leaf: } \\
\quad \text { Owned } \\
\quad \text { Leased. }\end{array}$ & $\begin{array}{l}13 \\
19\end{array}$ & $\begin{array}{l}14 \\
16\end{array}$ & $\begin{array}{l}15 \\
14\end{array}$ & $\begin{array}{l}15 \\
14\end{array}$ & $\begin{array}{l}15 \\
12\end{array}$ \\
\hline Total ... & 32 & 30 & 29 & 29 & 27 \\
\hline $\begin{array}{l}\text { Bright leaf: } \\
\text { Owned. } \\
\text { Leased. }\end{array}$ & $\begin{array}{l}17 \\
17\end{array}$ & $\begin{array}{l}18 \\
18\end{array}$ & $\begin{array}{l}19 \\
19\end{array}$ & $\begin{array}{l}19 \\
22\end{array}$ & $\begin{array}{l}19 \\
19\end{array}$ \\
\hline Total & 34 & 36 & 38 & 41 & 38 \\
\hline $\begin{array}{l}\text { Central Carolina: } \\
\text { Owned............. } \\
\text { Leased. }\end{array}$ & $\begin{array}{l}16 \\
26\end{array}$ & $\begin{array}{l}16 \\
26\end{array}$ & $\begin{array}{l}15 \\
24\end{array}$ & $\begin{array}{l}15 \\
20\end{array}$ & $\begin{array}{l}15 \\
19\end{array}$ \\
\hline Total. . & 42 & 42 & 39 & 35 & 34 \\
\hline $\begin{array}{l}\text { Eastern Carolina: } \\
\text { Owned } \\
\text { Leased........ }\end{array}$ & $\begin{array}{l}38 \\
29\end{array}$ & $\begin{array}{r}39 \\
\quad 29\end{array}$ & $\begin{array}{l}39 \\
28\end{array}$ & $\begin{array}{l}39 \\
25\end{array}$ & $\begin{array}{l}39 \\
23\end{array}$ \\
\hline Total...... & 67 & 68 & 67 & 64 & 62 \\
\hline $\begin{array}{l}\text { South Carolina: } \\
\text { Owned........ } \\
\text { Leased........ }\end{array}$ & $\begin{array}{l}28 \\
29\end{array}$ & $\begin{array}{l}28 \\
27\end{array}$ & $\begin{array}{l}28 \\
24\end{array}$ & $\begin{array}{l}28 \\
21 \\
\end{array}$ & $\begin{array}{l}28 \\
17\end{array}$ \\
\hline Total... & 57 & 55 & 52 & 49 & 45 \\
\hline $\begin{array}{l}\text { All warehousing corporations: } \\
\text { Owned.... } \\
\text { Leased.... }\end{array}$ & $\begin{array}{l}112 \\
120\end{array}$ & $\begin{array}{l}115 \\
116\end{array}$ & $\begin{array}{l}116 \\
109\end{array}$ & $\begin{array}{l}116 \\
102\end{array}$ & $\begin{array}{r}116 \\
90\end{array}$ \\
\hline Total & 232 & 231 & 225 & 218 & 206 \\
\hline
\end{tabular}

Data from the special report of the receivers for the Tobacco Growers' Cooperative Association, 1928.

A great deal of the criticism directed against the association involved charges of extravagance in the purchase of warehouses and in the employment of warehouse personnel. It is true that the association did have more warehouses than were necessary to handle the tobacco received. This surplus was due to (1) overestimating the quantity of tobacco the association would receive, (2) overestimating the amount of space necessary to handle tobacco according to the association's marketing and grading system, and (3) the apparent policy of purchasing all warehouses offered for sale. 
TABLE 28.-Changes in number of leased warehouses each year by warehousing corporations

\begin{tabular}{|c|c|c|c|c|c|c|}
\hline Warehousing corporation, and kind of change & ${ }^{1} 1922$ & 1923 & 1924 & 1925 & ${ }^{2} 1926$ & Total \\
\hline \multirow{2}{*}{\multicolumn{7}{|c|}{$\begin{array}{l}\text { Dark leaf: } \\
\quad \text { Leased }\end{array}$}} \\
\hline & $\begin{array}{r}19 \\
0\end{array}$ & $\frac{1}{4}$ & 2 & $\begin{array}{l}1 \\
1\end{array}$ & $\begin{array}{c}0 \\
2\end{array}$ & \\
\hline \multirow{2}{*}{\multicolumn{7}{|c|}{$\begin{array}{l}\text { Under le: } \\
\text { Bright leaf: } \\
\text { Leased.-. }\end{array}$}} \\
\hline & 17 & 3. & 4 & 5 & & \\
\hline $\begin{array}{l}\text { Relinquish } \\
\text { Under leas }\end{array}$ & 0 & ${ }_{18}^{2}$ & $\begin{array}{r}3 \\
19\end{array}$ & 22 & $\begin{array}{r}4 \\
19\end{array}$ & 11 \\
\hline \multicolumn{7}{|l|}{$\begin{array}{l}\text { Under lease at } \\
\text { Central Carolina: } \\
\text { Leased....... }\end{array}$} \\
\hline $\begin{array}{l}\text { Leased } \\
\text { Relinquished } 3 .\end{array}$ & $\begin{array}{r}26 \\
0\end{array}$ & $\begin{array}{l}4 \\
4\end{array}$ & $\begin{array}{l}1 \\
3\end{array}$ & $\frac{1}{5}$ & $\begin{array}{l}0 \\
1\end{array}$ & $\begin{array}{l}32 \\
13\end{array}$ \\
\hline \multirow{2}{*}{\multicolumn{2}{|c|}{$\begin{array}{l}\text { Eastern Carolina: } \\
\text { Leased........... }\end{array}$}} & 26 & 24 & 20 & 19 & \\
\hline & 30 & 2 & 2 & 4 & & \\
\hline $\begin{array}{l}\text { Relin } \\
\text { Unde }\end{array}$ & $\begin{array}{r}1 \\
29\end{array}$ & $\begin{array}{r}2 \\
29\end{array}$ & $\begin{array}{r}3 \\
28\end{array}$ & 27 & $\begin{array}{r}3 \\
23\end{array}$ & 16 \\
\hline \multicolumn{7}{|l|}{$\begin{array}{l}\text { Under leasea } \\
\text { South Carolina: } \\
\text { Leased....... }\end{array}$} \\
\hline $\begin{array}{l}\text { Leased_-_._. } \\
\text { Relinquished }\end{array}$ & $\begin{array}{l}30 \\
1\end{array}$ & $\begin{array}{l}4 \\
6\end{array}$ & $\begin{array}{l}1 \\
4\end{array}$ & $\begin{array}{l}3 \\
6\end{array}$ & $\begin{array}{l}0 \\
4\end{array}$ & $\begin{array}{l}38 \\
21\end{array}$ \\
\hline Unde & 29 & 27 & 24 & 21 & 17 & \\
\hline $\begin{array}{l}\text { Totals all warehousing corporations: } \\
\text { Leased }\end{array}$ & & & & & & \\
\hline $\mathrm{R}$ & 2 & 18 & 15 & 21 & 14 & \\
\hline & & & & & & \\
\hline
\end{tabular}

1 Feb. 8-Dec. 31.

2 Jan. 1-June 19.

Relinquished-warehouse destroyed, contract expired, or contract canceled.

Actual deliveries of tobacco to the association during its first year amounted only to 35.4 per cent of the production of the tri-State area and were less during the following years, whereas at least 55 per cent was expected. Expectations of delivery were too optimistic and were based on uncertain grounds. If the association received the quantity of tobacco anticipated, it is doubtful if many of the receiving points would have had too much warehouse space. The association's method of handling tobacco required less space than the auction-floor system because all tobacco of the same grade was combined, and a longer period of marketing was possible.

The policy of the purchasing committee was to buy or lease all warehouse properties offered for sale or rent, in order to reduce competition and to win the support and good will of the warehousemen and their customers. The owners of warehouses had been assured, prior to organization, that it was to be the policy to cause as little hardship as possible to them and that the association would undertake to purchase or lease all warehouse property offered. Before a sale or lease was concluded, a valuation of the property was made by several supposedly disinterested persons as a valuation or arbitration board, to arrive at a reasonable price. Many such valuations were too high, as they were made by bankers and other persons who had mortgages or other interests in the property, and some warehouses are said to have been purchased at prices far in excess of any of the valuations placed on them. In some districts, it appears that directors, members, and even officials of the association who were personally interested in warehouses urged their purchase upon the warehouse committee. 
Again, well-known men, interested in warehouse property, were accused of haring supported the association becanse they wished to unload unprofitable properties on the association. Sereral warehouses were purchased in what were known as "dead" markets, that is, in towns and villages in which the small quantity of tobacco offered for sale had necessitated the closing of the tobacco markets. Business men in these torns were eager to hare a market reopened. Some of the warehouses bought under these conditions had, for a time, been used as garages or storehouses and had greatly depreciated in value. In some markets warehouses were opened merely to enable the association to obtain members in those localities and possibly with the knowledge that these markets would not operate.

In a letter to the executire committee, dated October 10, 1922, the director of the warehouse department wrote:

There are being operated in the bright and dark belts, this rear. 145 markets. We should next rear reduce this to 115 markets. as we opened this rear a great many markets. especially in eastern Carolina and South Carolina with the rier of helping the sign-up, and I think it did materialls increase it, and should be closed next year. On a sood many of them we will not handle as much as 250.000 pounds of tobacco.

Realizing alreadr at this date that all of the warehouses controlled were not necessary the letter continued:

I also desire to call rour attention to the fact that this department is using evers effort to subrent its properties where nnt needed. for the storage of cotton and other uses, and expects to receire a goodly sum from this source.

That this policy continued into 1923 is borne out br the minutes of the executive committee of February 5, 1923, in which it is stated:

Director Watkins reported that he was clnsing warehouse purchases as rapidls as the legal department approred of titles. and so forth; that he fras renting surplus warehouses to good adrantage and had other prospects. Had no other report to make. but would like to get a committee to go with him to four or fire warehouses.

In some tobacco markets all of the warehouses (three or four in some instances) were purchased when one would hare sufficed. Some of these were nerer operated. Table 29 and Figure 15 give the frequency of the number of warehouses purchased and the number controlled by warehousing corporations in 1923. In the 149 markets where it controlled warehouses the association had 255 warehouses. In 82 markets of the 149 it orrned 118 warehouses: in 72 out of the 149 markets it controlled 2 or more warehouses. In 44 markets it controlled 2 warehouses, in 22 it controlled 3, and in 6 markets it controlled 4 warehouses. In only 1 market did the association buv as many as 4 warehouses, but in 6 it owned 3 , and in 21 it owned 2 warehouses.

Ill will dereloped toward the association among the townspeople of some markets, because by taking all the warehouses the association forced the nonmember growers to sell their product in other markets where these growers then did much of their buying.

Far too many warehouses were purchased or leased, and eren in the first year it was found necessary to sell. sublease. or otherwise dipose of much of this warehouse property at a distinct loss. Far too much space had been acquired not only for the 1922 crop but also for the 1923 receipts which were larger. During the next two years receipts fell off greatly, so eren less space was necessary. 
But it should be remembered that provision had to be made before the crop was delivered and the warehouses were purchased at a time when there was every indication of a big delivery by the members. When delivery failed to materialize as anticipated, the surplus property was disposed of by sale or sublease as rapidly as possible. This naturally was a slow and unprofitable process, as at this time it was very difficult to find suitable purchasers or lessors because of the uncertainty of the effect of the association on the value of warehouse property and because of the prevailing distress at this time in these districts. Many warehouses not sold or subleased were closed in markets or in entire districts where the volume of tobacco delivered did not justify a warehouse.

TABLE 29.-Number of markets in which the five warehousing corporations controlled one to four warehouses in 1923 and the number of warchouses purchased ${ }^{1}$

\begin{tabular}{|c|c|c|c|c|c|c|}
\hline \multirow{2}{*}{ Warehousing corporation and form of control } & \multicolumn{5}{|c|}{$\begin{array}{c}\text { Markets with number of association } \\
\text { warehouses indicated }\end{array}$} & \multirow{2}{*}{$\begin{array}{c}\text { Total } \\
\text { associa- } \\
\text { tion } \\
\text { ware- } \\
\text { houses }\end{array}$} \\
\hline & 1 & 2 & 3 & 4 & $\begin{array}{l}\text { Total } \\
\text { mar- } \\
\text { kets }\end{array}$ & \\
\hline \multicolumn{7}{|l|}{ Dark-leaf: } \\
\hline Controlled & 17 & 6 & 1 & 0 & 24 & \\
\hline $\begin{array}{l}\text { Purchased } \\
\text { Bright-leaf: }\end{array}$ & 9 & 3 & 0 & 0 & 12 & 15 \\
\hline $\begin{array}{l}\text { Brignt-lear: } \\
\text { Controlled.... }\end{array}$ & 6 & 7 & 5 & 1 & 19 & \\
\hline $\begin{array}{l}\text { Purchased.... } \\
\text { Central Carolina: }\end{array}$ & 8 & 4 & 1 & 0 & 13 & 19 \\
\hline \multicolumn{7}{|l|}{ Central Carolina: } \\
\hline $\begin{array}{l}\text { Controlled....- } \\
\text { Purchased.... }\end{array}$ & 18 & 5 & 3 & 2 & 28 & 45 \\
\hline \multicolumn{7}{|l|}{ Eastern Carolina: } \\
\hline Controlled & 26 & 18 & 6 & 0 & 50 & 80 \\
\hline $\begin{array}{l}\text { Purchased..... } \\
\text { South Carolina: }\end{array}$ & 19 & 6 & 3 & 0 & 28 & 40 \\
\hline \multicolumn{7}{|l|}{ South Carolina: } \\
\hline Purchased.... & 9 & 6 & 1 & 1 & 17 & 28 \\
\hline Total: & & & & & & \\
\hline Purchased.-- & 54 & $\begin{array}{l}44 \\
21\end{array}$ & $\begin{array}{r}22 \\
6\end{array}$ & $\begin{array}{l}0 \\
1\end{array}$ & $\begin{array}{r}149 \\
82\end{array}$ & 118 \\
\hline
\end{tabular}

1 Controlled includes both purchased and leased warehouses. Not all warehouses controlled were operated.

Data from the association list of warehouses by corporations.

In further extenuation of the policy it must be said that the buying of all of the warehouses offered for sale was an effort to win the support instead of the antagonism of the warehousemen. At the time it seemed that to have these warehousemen employed by the association would be an aid, but it was later learned that many were not in sympathy with the cooperative movement, so that, in many instances to have them in the association did more harm than good.

Soms of the directors and warehousemen have been accused of questionable or dishonest practices in the purchase of some of these warehouses. Although there were some doubtful purchases, not a single instance of corruption has been proved. However, from a study of the warehouse files of legal documents and other material, and from interviews with business people and tobacco men, one is led to believe that great extravagance was displayed in the purchase of warehouse property and that even the most optimistic idea as to 
the future of the association did not justify the number of properties bought or the prices paid for them. The association's idea of causing as little loss as possible to owners of warehouses did not justify such wholesale, and as it subsequently developed, unwise purchase of property. It is possible that more of the warehouses could have been leased instead of purchased. The unfortunate purchase of warehouses and the subsequent warehousing policies contributed to a large extent to the dissatisfaction of members who became increasingly suspicious of the conduct of the association affairs.

The prices paid in many if not most of the purchases of warehouse property seem, now at least, to be exorbitant. There were at least two causes for the high prices. One was the raising of prices of warehouse property when it was learned that the association intended to take over all warehouse property offered for sale or lease. The second reason was that the prices asked for the warehouses were higher than the cash valuation of such property because the association was able to make only very small cash payments when the warehouses were purchased and had to use long-term credit for the remainder of the cost.

Table 30 shows the purchase price of property held by the different warehousing corporations and the auction bid on such property made to the receivers up to 1928 . The offers were only 36.5 per cent of the original purchase prices; the biggest loss was incurred in the sale of the property of the Eastern Carolina Warehousing Corporation, as would be expected because of the overvaluation at the time of purchase by the association. However, property sold under a receivership is usually sold under conditions unfavorable to the seller. Furthermore, the warehouses were sold at a time when the general value of property was at a lower level than it was in 1922, when they were purchased. In some markets only one buyer was willing to take the property and the receivers were forced to accept any reasonable bid made by such buyer.

TABLE 30.-Purchase prices to the association of warehouse property and auction bids made to receivers

\begin{tabular}{|c|c|c|c|}
\hline \multirow[b]{2}{*}{ Warehousing corporation } & \multirow[b]{2}{*}{ Purchase price } & \multicolumn{2}{|c|}{$\begin{array}{l}\text { Auction bids made to } \\
\text { receivers }\end{array}$} \\
\hline & & Total amount & $\begin{array}{l}\text { Percent- } \\
\text { age of } \\
\text { purchase } \\
\text { price }\end{array}$ \\
\hline 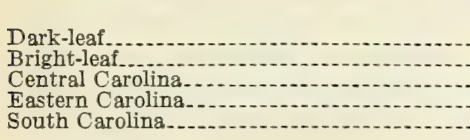 & $\begin{array}{r}\text { Dollars } \\
333,923.20 \\
491,407.10 \\
413,741.45 \\
1,173,462.83 \\
543,538.59\end{array}$ & $\begin{array}{l}\text { Dollars } \\
134,248.00 \\
193,818.00 \\
251,130.00 \\
303,327.50 \\
197,420.00\end{array}$ & $\begin{array}{l}40.2 \\
39.4 \\
60.7 \\
25.8 \\
36.3\end{array}$ \\
\hline Total......... & $2,956,073.17$ & $1,079,943.50$ & $\overline{36.5}$ \\
\hline
\end{tabular}

Receivers' Report, 1928.

GRADING

When the association was formed there was no standardized, or generally recognized, grading system and a wide variation in prices 
was paid for tobacco of the same quality and type. Tobacco growers complained about this difference in prices for the same quality and type of tobacco. One tobacco farmer related that in 1921 he offered for sale the same pile of tobacco on the auction floor ten times the same day with the following results $(1, p .28)$ :

\begin{tabular}{|c|c|}
\hline Cents & Cents \\
\hline First sale_... & Sixth sale_ \\
\hline econd sale_..... & Seventh sale_. \\
\hline Third sale______ & Eighth sale \\
\hline Fourth sale_-_-_-_e- 37 & Ninth sale \\
\hline fth sale_-_n_... $341 / 2$ & Tenth sale_-_no $361 /$ \\
\hline
\end{tabular}

A standardized and recognized grading system was a prerequisite to the pooling of the tobacco of the same grade and type, to the equitable treatment of members, to the proper financing of member advances and payments, and to the sale of large quantities of uniform tobacco by sample to the manufacturers. One of the first duties of the leaf department of the association was to devise adequate and workable sets of grades for the different types of tobacco handled. The warehouse division of the United States Bureau of Agricultural Economics, had been working on the standardization of grades for the different types of tobacco since 1920, and several tentative sets of grades had been formulated prior to $1922 . .^{33}$ The association appealed to the Bureau of Agricultural Economics for assistance in working out a suitable grading system. As a result of a conference between officials of the bureau and of the association, the tentative sets of grades of the Bureau of Agricultural Economics were adopted by the association after considerable amendment on the advice of association officials.

These grades were not departed from in any essential respect during the following years, but some refinement of grades was found necessary. At that time the workers of the Bureau of Agricultural Economics had not sufficiently refined the tentative official grades for the various types of tobacco and were not prepared to take any responsibility for the grades adopted by the association, which was allowed to use the sets of grades drawn up at the conference with the distinct understanding that such grades were to be regarded as association, and not as Government, standardized grades. The classification of the grades adopted by the association, however, bears a close resemblance to the system subsequently completed by the warehouse division of the Bureau of Agricultural Economics.

The flue-cured tobacco grown in South Carolina, the eastern section of North Carolina (both known as the new belt) and the piedmont section of North Carolina and Virginia, (known as the old belt) differs substantially in quality and texture, and lends itself to division into three different types. Besides the flue-cured tobacco, the association also handled the dark-fired and sun-cured tobacco varieties of Virginia. The five separate pooling areas were created to include these five types of tobacco. (Fig. 16.) The tobacco in each pooling area was of a sufficiently uniform type to justify such

\footnotetext{
s3 Among other things, as early as 1920 the Federal Trade Commission in its report on The Tobacco Industry recommended "that a Federal system of grading leaf tobacco be established by the Department of Agriculture. The authority to establish such a system apparently has been given that department under section 19 of the United States warehouse act. It is believed that this would tend to stabilize market values under abnormal conditions such as prevailed during part of last season."
} 
division, and a separate set of grades was drawn up for each pooling area. In some areas, where the type of tobacco was somewhat different, members claimed that the grading system did them an injustice. This was true especially along the eastern edge of the new belt of North Carolina.

The leaf department had to bring together and train a sufficient number of graders in preparation to handling the 1922 crop of tobacco. Most of these men were recruited from persons who had been in the leaf-tobacco business for years and it was not difficult for them to become accustomed to the new system of grading. But the grading of tobacco is, to a certain extent, a matter of independent judgment, and even among the best graders some lack of uniformity or regularity may exist. To insure a greater degree of uniformity of grading within each pooling area, supervising graders were appointed to visit the different receiving points and to check the grading. Most of these graders and supervising graders were expert at grading only one type of tobacco. Graders who failed to grade satisfactorily at some markets were often found to be more familiar with another type of tobacco.

\section{GRADING PRACTICES}

Although the grading system was undoubtedly workable, the actual operation of grading was not always strictly and satisfactorily carried out. Pressure was frequently brought to bear upon graders by farmers to overgrade their tobacco. Sometimes the graders were partial; farmers often were friends or relatives of the grader. In other instances the tobacco was overgraded in order to prevent a member from becoming disatisfied. There was some evidence that the practice of discrimination prevailing under the auction system of marketing was not entirely absent, to the disadvantage of the less influential farmers. It also frequently happened that a whole community managed to have graders removed to other warehouses, if they graded too strictly or contrary to the ideas of the farmers. It is a well-known fact that the farmers as a whole overestimated the quality of their crops.

The supervising graders were continuously employed to correct any tendency to unfair or not uniform grading. It has been maintained in some quarters that some officials of the association did not frown on the tendency toward overgrading as members were thereby paid higher advances and were kept better satisfied. There is no doubt that in spite of the efforts of the supervising graders, a great deal of tobacco was overgraded. The balance sheet of June 30, 1926, shows that members were overpaid $\$ 404,326.03$ on tobacco; a large part of these overpayments was claimed to be due to overgrading. Every year it was found necessary to transfer several hundred thousand pounds to lower grades.

In spite of these defects, however, the adoption and development of a grading system proved a great boon to the tobacco producers of the South. It taught farmers how to sort their tobacco more skillfully by quality and type, and gave them a better idea of the relative value of the different grades. This experience still lives with them and helps them, although the association no longer functions. The 
State grader at the market at Lynchburg, Va., recently stated that association members, on the average, sorted their tobacco better and received higher average prices than farmers who had not belonged to the association.

Taking everything into consideration, the grading system adopted by the association was one of the positive and useful contributions of the association, and the officials of the association should be given credit for this contribution. It demonstrated that the grading of tobacco was feasible. The grading system met with the approval of the War Finance Corporation and the Federal intermediate credit bank and was used as the basis of financing both the green and redried tobacco.

A number of independent warehousemen and leaf dealers were visited and their opinions asked regarding the association grading system. The unaminous opinion was that on the whole the grading system was satisfactory. This is borne out by the fact that several of the largest tobacco companies purchased large quantities of tobacco from the association and seemed pleased with the grading. On the other hand one of the reasons advanced by the Imperial Tobacco Co. for its refusal to buy tobacco from the association was that the association grading was found to be unsatisfactory and unsuitable for their requirements (12).

Table 31 shows the attitude of the members toward the grading by the association as brought out in the membership survey in answer to the question: "Was your tobacco satisfactorily graded by the association "?

REDRYING POLICIES

Tobacco in the green state is subject to heating and deterioration unless it is given constant care. To prevent tobacco from spoiling it must be put through a conditioning process. All tobacco received by the association which could not be sold within a few days after delivery was immediately consigned to a redrying plant for conditioning. It became the intention of the association after 1922 to operate its own redrying plants, but the investment in warehouse property was so heavy that it was considered best to allow private redriers to redry the association tobacco in order to avoid the heavy investment. The association hoped to own and operate its own redrying plants at a later date.

TABLE 31.-Replies to question, "Was your tobacco satisfactorily graded by the association?"

\begin{tabular}{|c|c|c|c|c|c|c|}
\hline \multirow[b]{2}{*}{ Reply } & \multicolumn{6}{|c|}{ Replies from members of- } \\
\hline & $\underset{\text { pool }}{\text { Sun-cured }}$ & $\underset{\text { pool }}{\text { Dark-fired }}$ & $\begin{array}{l}\text { Old-belt } \\
\text { pool }\end{array}$ & $\begin{array}{c}\text { Eastern } \\
\text { Carolina } \\
\text { pool }\end{array}$ & $\begin{array}{c}\text { South } \\
\text { Carolina } \\
\text { pool }\end{array}$ & All pools \\
\hline $\begin{array}{l}\text { Yes... } \\
\text { No } \\
\text { Don't know..... } \\
\text { No answer..... }\end{array}$ & $\begin{array}{r}\text { Number } \\
27 \\
3 \\
1 \\
\end{array}$ & $\begin{array}{r}\text { Number } \\
80 \\
21 \\
1\end{array}$ & $\begin{array}{r}\text { Number } \\
131 \\
63 \\
1 \\
\end{array}$ & $\begin{array}{r}\text { Number } \\
92 \\
27 \\
13 \\
22\end{array}$ & $\begin{array}{r}\text { Number } \\
110 \\
45 \\
5 \\
1\end{array}$ & $\begin{array}{r}\text { Number } \\
440 \\
159 \\
21 \\
23\end{array}$ \\
\hline Total & 31 & 102 & 195 & 154 & 161 & 643 \\
\hline
\end{tabular}


The board of directors does not seem to have even considered the matter of operating its own redrying plants during its first receiving season. The $1923 \mathrm{crop}$ was a large one and the association was faced with the problem of redrying a much greater volume than during the previous year at what appeared to be an increased redrying rate. Evidence was produced which purported ${ }^{34}$ to show that some redrying companies were about to increase their charges for redrying. Whether or not this alleged combination of redrying. interests against the association was ever dangerous is a matter of question.

The suggestion was then made to the board of directors that the association erect its own redrying plants. After considering this suggestion it was rejected by the board because the association had already assumed large obligations in the matter of purchasing warehouses and the board did not believe that it was in a position to assume further obligations for capital outlays at that time. ${ }^{35}$

The same problem was brought before the executive committee at a meeting held on June 9, 1925. The executive committee also did not look with favor upon the additional expense of purchasing or erecting redrying plants because of the heavy obligations incurred in the purchase of warehouse property. A resolution was passed authorizing the investment by officers, directors, employees, and members in redrying plants for the purpose of redrying association tobacco. This resolution, however, was not included in the minutes of the executive committee presented to the board of directors at its subsequent meeting. It was not discovered until at the board meeting held on August 18, 1925, that this resolution of the executive committee had been omitted. The resolution ${ }^{36}$ was then approved and the board assumed responsibility for the policy.

The permission of the executive committee, however, seems to have been clothed in a great deal of mystery, and the irregularity did not serve to place the matter in a better light. Many members of the board of directors maintain that they had no knowledge that any officers and directors of the association had any interest in redrying plants until the report of the agricultural investigating committee appeared in the spring of 1925. In any case, the least desirable aspects of the redrying policy came to light only with the publication of the Federal 'Trade Commission's report in December, 1925 (12).

At a meeting of the board of directors on January 16, 1926, in the face of the report of the Federal Trade Commission, the board expressed its approval of its officials engaging in the redrying of tobacco delivered to the association, and approved the resolution adopted on August 18, 1925. On April 3, 1926, however, the board adopted the following resolution:

Resolved that this board does hereby rescind all resolutions hereto passed approving or ratifying in any sense any redrying transactions whatever with

${ }^{34}$ Senate Document 34 (12, $\left.p .91\right)$. "The evidence does not indicate there was a general tendency on the part of the redriers, either in concert or individually, to raise the charges for redrying in 1923.

${ }_{35}$ Report of the agricultural investigating committee, 1925.

${ }_{36}$ From the minutes of the board of directors meeting on Sept. 22, 1925 . The secretary presented to the board a correction in the minutes of the executive committee meeting of June 9,1923 , as authorized in the resolution of the board of directors of Aug. 18, 1925. This correction is as follows: "On motion the executive committee of the Tobacco Growers' Cooperative Association authorizes the investment by officers, directors, employees, and members in redrying plants for the purpose of redrying association tobacco; Director Hurt requested that he be recorded as voting against this resolution." 
Mr. Watkins, Mr. Patterson, Mr. Edmondson or the Edmondson Tobacco Co., on the ground that all such resolutions were passed without full disclosure to this board of directors of all pertinent facts.

At the same meeting it also approved of prosecuting vigorously these parties for all claims against them.

It is doubtful if either the executive committee or the board of directors was placed in possession of all of the facts of the case prior to January, 1926. The executive committee probably took the facts as presented to them at their face value and authorized the redrying policy in good faith. Apparently the members of the association never approved of the action of the executive committee in June, 1923, or of the action of the board of directors in August, 1925. No prior approval by the board of directors was found for Messrs. Watkins and Patterson to privately dry association tobacco in 1922.

The minutes of the board of directors for January 19, 1926, state in part:

It has been made evident that the members of the board of directors with a few exceptions, were not aware, prior to June, 1923, that Manager Patterson and Watkins had an interest in the Edmondson redrying activities for the 1922 crop; and that most of the directors did have general knowledge of such activities for the 1923 and the 1924 crops.

Evidently, knowledge of the fact that certain officials of the association were engaged in redrying tobacco for the association became known to some of the members before the spring of 1925 . In their report at this time the agricultural investigating committee stated: "The officers of this association who engaged in this redrying business have come in for considerable criticism." The committee felt that the knowledge of the members of the association that its officials were financially interested in redrying plants was a cause of declining support by members.

In regard to redrying of tobacco for the association by officials in 1922, the report of the Federal Trade Commission is of interest $(12, p .85)$ :

The facts are that Messrs. Patterson, general manager, and Watkins, director of warehouses, made their prirate arrangements to redry association tobacco through the Edmondson Tobacco Co., prior to the delivery of the 1922 crop, and did redry cooperative tobacco of the 1922 crop in exactly the same way they were represented to hare begun in 1923. Furthermore, at least 15 other officials were privately interested in 11 other redrying concerns which redried association tobacco of the 1922 crop. No new firms with which important officers were connected began redrying this cooperative's tobacco in 1923 . Of the total volume redried by the association in 1922 and 1923, a larger proportion, or 48 per cent, was redried in 1922 in plants in which officials were interested than was redried in such plants in 1923 when the proportion was 44 per cent.

According to a report of the association in 1925 " on the "Redrying policy of the association," some of its representatives at least were aware of the fact that at least one of its officers was, as early as 1922, redrying association tobacco. ${ }^{37}$ This official, the sales manager

s7 In the spring of 1922 , F. D. Williams was employed as sales manager of the darkfired department, to have charge of the bandling and selling of dark-fired tobacco. It was agreed between Mr. Williams and the representatives of the association employing him that he could continue to operate his redrying plants, and that he could redry association tobacco, provided a fair price could be agreed upon. These representatives of the association desired him to redry association tobacco. 
of the dark-fired department, was the third largest redrier of association tobacco among the officials doing this redrying in 1922 and 1923.

The executive committee did not seem to have been aware that, in 1922, 24.6 per cent of the association's tobacco was redried by a concern (the Edmondson Tobacco Co. of South Boston and Chatham, Va.), in which F. R. Edmondson, a warehouseman; R. R. Patterson, the general manager of the association; and T. C. Watkins, the head of the warehouse department and a director of the association, had become financially interested. Nor was the executive committee aware that in 1922 these officers had made substantial profits and each had acquired a one-third share in the redrying plant without the investment of any capital, although they had guaranteed certain loans for the purchase of redrying equipment which had been paid out of the first year's profits.

As a result of redrying a large part of the 1923 crop of tobacco, the redrying plant made profits of $\$ 157,760.96$, and these two officers of the association were able to withdraw about $\$ 40,000$ each as his share of the profits (12, p. 92) and to retain equities in the company of about $\$ 30,000$ each. These two officers were not the only persons connected with the association who had investments in plants that redried association tobacco. It mould appear that at least $30 \mathrm{em}$ ployees of the association were financially and directly interested in plants which, at one time or another, redried tobacco for the association. At least three of these association officials were association directors, and one was a public director. ${ }^{38}$ In $1922,47.9$ per cent of the tobacco redried was redried in plants in which officers connected with the association were interested. (Table 32.) In 1923 and 1924 the proportions were 44 per cent and 51.4 per cent, respectively

TABLE 32.-Receipts of tobacco, quantities redried, and quantities redried by association officials and by Edmondson Tobacco Co., 1922-1925

\begin{tabular}{|c|c|c|c|c|c|c|c|}
\hline Crop & $\begin{array}{l}\text { Tobacco } \\
\text { received }\end{array}$ & \multicolumn{2}{|c|}{ Quantity redried } & \multicolumn{2}{|c|}{ Redried by officials } & \multicolumn{2}{|c|}{$\begin{array}{l}\text { Redried by Edmondson } \\
\text { Tobacco Co. }\end{array}$} \\
\hline $\begin{array}{l}1922 .- \\
1023=- \\
1921= \\
1925=\end{array}$ & $\begin{array}{c}\text { Pounds } \\
163,590,000 \\
180,138,000 \\
103,841,000 \\
83,634,000\end{array}$ & $\begin{array}{c}\text { Pounds } \\
51,297,000 \\
115,471,000 \\
83,384,000 \\
70,816,000\end{array}$ & \begin{tabular}{|c|} 
Per cent 1 \\
31.4 \\
64.1 \\
80.3 \\
84.7
\end{tabular} & $\begin{array}{l}\text { Pounds } \\
24,588,908 \\
50,803,214 \\
42,889,058 \\
0\end{array}$ & $\begin{array}{r}\text { Per cent }{ }^{2} \\
47.9 \\
44.0 \\
51.4\end{array}$ & $\begin{array}{l}\text { Pounds } \\
12,621,312 \\
25,543,873 \\
17,988,513 \\
0\end{array}$ & $\begin{array}{r}\text { Per cent }{ }^{3} \\
51.3 \\
52.2 \\
41.9 \\
\end{array}$ \\
\hline Total. & $531,203,000$ & $320,968,000$ & 60.4 & $118,281,210$ & 36.9 & $57,153,698$ & 48.3 \\
\hline
\end{tabular}

1 Green weight received $=100$ per cent.

Quantity reciried $=100$ per cent.

${ }^{3}$ Quantity redried by officials $=100$ per cent.

3 Directors stand in a fiduciary relation to the corporation and are held to the utmost good faith in their dealings with it. They must manage its business with a view to yromoting the common interests, and can not directly or indirectly derive personal profit or advantage from their position, which is not shared by all the stockholders. All secret profits which a director receives in any transaction in connection with the affairs of the corporation must be accounted for to the corporation, although the transaction may also be of adrantage to the corporation. With reference to special contracts between director and their associations, the cooperative marketing act of North Carolina, under whieh the Tobacco Growers' Cooperative Association was formed, provides: "No director, guring the term of his office, shall be a party to a contract for profit with the association differing in any way from the business relations accorded regular members or holders of common stock of the association, or to any other kind of contract differing from terms generally current in that district." This provision invalidates any contract of the prohibited type entered into by a director with an association formed under that statute. All the board of directors of an association formed under that act voting in favor of such a contract could not authorize it, because it would be contrary to the statute. 
The Edmondson Tobacco Co. had redried 22.8 per cent of all tobacco redried by the association during its first three years of operation. Of the tobacco redried in plants in which association officials were financially interested, the Edmondson Co. had handled 48.3 per cent.

In 1925 the association leased redrying plants to redry its tobacco and operated on a cost basis. It cost the association $\$ 1.02$ per 100 pounds ( $\$ 0.98$ green basis) to redry its own tobacco in 1925 , whereas when the Edmondson Tobacco Co. charged $\$ 1.50$ to redry tobacco of the $1924 \mathrm{crop}$, the total cost of redrying only (exclusive of freightage, storage, and other charges) amounted to $\$ 1.64$ per 100 pounds. The Federal Trade Commission found that the cost per 100 pounds to the Edmondson Tobacco Co. of redrying tobacco for the association was $\$ 1.15$ in 1922 , and $\$ 1.01$ in 1923 . It is evident that the association could have saved a great deal of expense in redrying its tobacco if it had operated its own plants during the first three years of its operation.

It has been charged by some that when tobacco was sent to redriers, who redried not only association tobacco but tobacco purchased and redried for themselves, they substituted a lower grade of their own purchases for the association tobacco, when repacking. It is not possible to prove this charge, but such substitution is a possibility, and the association was aware of the danger. If this charge is true it would explain why much of the tobacco was found to be apparently overgraded when the association was put in the hands of receivers.

The association was injured not only in a financial way by the redrying policy but it was injured more by the propaganda, statements, and exaggerations based on this policy which were made by interests antagonistic to the association. The redrying was pointed out as one of its policies of mismanagement, and was used to create discontent, suspicion, and disloyalty among the members.

It has been maintained in defense of the redrying by officials that these officers had saved the association money. It is true that the Edmondson Tobacco Co. in 1924 reduced its redrying charges from $\$ 1.75$ to $\$ 1.50$ per 100 pounds and that many of the other companies were forced to follow similar reductions. During the first year (1922) over two-thirds of the tobacco delivered was sold green, the remainder was redried at various independent redrying plants, at prices ranging from $\$ 1$ to $\$ 2.50$ per 100 pounds. The average cost or redrying only (exclusive of freightage and other charges) was $\$ 1.80$. However, it is generally known that any redrying plant that receives a large, certain, and steady volume of tobacco can redry it at a low cost. With this kind of volume assured it operates under little risk in competition with plants that operate upon the basis of a smaller or more uncertain volume.

Apparently little was known by the public in regard to the redrying policies of the association until the report of the Federal Trade Commission was issued on December 23, 1925. This report was made upon a resolution passed by the United States Senate on February 9,1925 , because of complaints from the tobacco cooperatives, directing the Federal Trade Commission to make an investigation of the charges against the American Tobacco Co. and the Imperial Tobacco Co. of boycotting certain tobacco growers' cooperative marketing 
associations. A large part of the report was devoted to the unfortunate and unusual redrying policy of the association. Undoubtedly this report, making public some of the policies of the association, hastened its failure. The report gave some facts as to irregularity in management whereas previously the statements of mismanagement were based largely on suspicion, rumor, and even falsehood.

To learn the importance of the effect of the redrying policy upon the attitude of the members, during the membership study they were asked the question: "Do you think that the association would have succeeded if the officers had not been personally interested in the redrying of association tobacco?" That the redrying by officials was not considered the only or chief cause of the failure of the association is shown by Table 33. Of the members interviewed 20.8 per cent felt that the redrying policy caused the failure; 56.2 per cent were of the opinion that the association would not have succeeded even if the redrying policy had been different.

TABLE 33.--Replies to question, "Do you think the association would have succeeded if the officers had not been personally interested in the redrying association tobacco?"

\begin{tabular}{|c|c|c|c|c|c|c|}
\hline \multirow[b]{2}{*}{ Reply } & \multicolumn{6}{|c|}{ Replies from members of- } \\
\hline & $\begin{array}{c}\text { Sun-cured } \\
\text { pool }\end{array}$ & $\begin{array}{c}\text { Dark-fired } \\
\text { pool }\end{array}$ & $\begin{array}{l}\text { Old-belt } \\
\text { pool }\end{array}$ & $\begin{array}{c}\text { Eastern } \\
\text { Carolina } \\
\text { pool }\end{array}$ & $\begin{array}{l}\text { South } \\
\text { Carolina } \\
\text { pool }\end{array}$ & All pools \\
\hline $\begin{array}{l}\text { Nos } \\
\text { Yes } \\
\text { Don't know } \\
\text { Other answers }\end{array}$ & $\begin{array}{r}\text { Number } \\
8 \\
11 \\
9 \\
3\end{array}$ & $\begin{array}{r}\text { Number } \\
35 \\
44 \\
19 \\
4\end{array}$ & $\begin{array}{r}\text { Number } \\
143 . \\
15 \\
27 \\
10\end{array}$ & $\begin{array}{r}\text { Number } \\
97 \\
12 \\
42 \\
3\end{array}$ & $\begin{array}{r}\text { Number } \\
78 \\
52 \\
29 \\
2\end{array}$ & $\begin{array}{r}\text { Number } \\
361 \\
134 \\
126 \\
22\end{array}$ \\
\hline Total . . & 31 & 102 & 195 & 154 & 161 & 643 \\
\hline
\end{tabular}

STORING

As green tobacco can not easily be stored for prolonged periods, and as the association did not sell all of its tobacco immediately, it had to store large quantities of tobacco after it was redried. The association attempted to store the bulk of the tobacco on hand at a few concentration points, to save expense and to facilitate sales and handling. These points were usually close to redrying plants, or at important tobacco markets, or at tobacco-manufacturing cities, or close to places convenient to rail and water transportation.

\section{PURCHASING OF SUPPLIES}

The Tobacco Growers' Cooperative Association did not directly perform the function of buying fertilizers, feeds, or other supplies for its members. It did not consider such buying advisable because of the opposition such a service to its members would provoke from the local merchants dealing in those commodities. It did permit the locals to obtain competitive prices, and to buy where they could to the best advantage. The association encouraged this collective buying by permitting its employees to render any service they could in this work. A number of the stronger locals engaged in the purchase of supplies for their members. 
The membership fee, due and payable upon entrance, was $\$ 3$. To facilitate the sign-up the association would accept notes in lieu of cash payments for the amount of the membership fee, or it would charge the amount against the account of the member and deduct it from his net returns when he delivered tobacco to the association.

Beside the fund from membership fees, which was used to meet the expenses of organization, the association had no funds with which to begin operation. The organization expenses, according to the audit report February 7, 1924, were as follows:

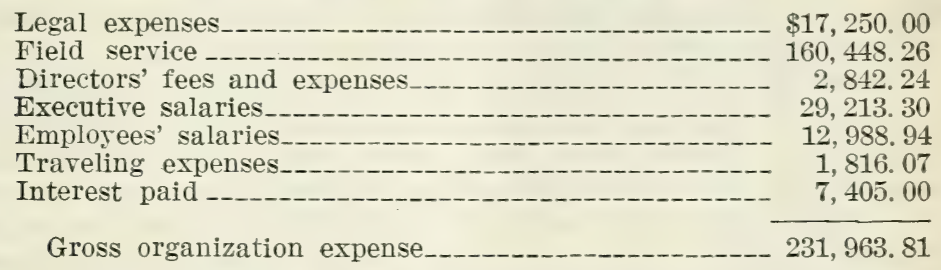

Within two or three months prior to the opening of the markets and the receiving of tobacco, a sufficient sum of money had to be available to purchase supplies, operating equipment, and all other articles necessary to enable the association to receive the large volume of tobacco.

The problems of financing of the association fell under three main heads: (1) Financing advances to farmers for green tobacco delivered; (2) financing redried stored tobacco; and (3) financing the sales of tobacco from the time hogsheads were delivered to the customer until it was finally paid for. Sometimes a period of 30 to 60 days elapsed before final payment was received.

All of the association receipts of tobacco of the same type and grade were to be put in annual pools. Upon receipt of the member's tobacco, it was graded by the grader of the leaf department and commingled with tobacco of the same type and grade of other members. The member was given an advance payment on the basis of grade and weight and was issued participation certificates showing the amount paid and the quantity and grade of tobacco delivered. It was necessary to make these advance payments to members immediately upon their delivery of green tobacco. This presented a most serious problem as many of the bankers, who professed to know something about tobacco, maintained that green tobacco was not good collateral because of the danger of rapid deterioration. This argument was used for refusing to make loans to the association, notwithstanding the fact that it was the common practice to loan large sums to leaf dealers for the purpose of buying tobacco in exactly the same form.

In some cases this argument was sincere, but frequently it was used as an excuse to avoid lending money to the association in order not to displease some influential depositors and customers of the banks. Considerable opposition to the association existed among financial institutions throughout the entire territory, especially on the part of the large and important banks. It was necessary to obtain a large amount of the preliminary money from the friendly country and city banks in the form of short loans, issued entirely 
on the faith and belief that the association would be able to pay them out of the tobacco received. Approximately $\$ 500,000$ was obtained in this way in loans ranging from $\$ 1,000$ to $\$ 50,000$ each. Many of the bankers throughout the tobacco territory were unwilling to assist the association for fear of antagonizing the large tobacco companies. Furthermore, in many of the smaller towns, leaf dealers and warehousemen were financially interested in the local banks and brought pressure to bear upon them not to assist the association in any way. Many of the small country bankers, however, were very sincere in their support of the cooperative movement, and it was from these friendly bankers that the association succeeded in raising the first $\$ 500,000$. This amount was paid off as soon as possible from the sales of green tobacco.

In August, 1922, the association succeeded in borrowing $\$ 500,000$ from a large bank in Pittsburgh, $\mathrm{Pa}$., and $\$ 300,000$ from a bank in St. Louis, Mo. These loans were made for a period of 90 days. The association had meanwhile demonstrated that loans on green tobacco were reasonably safe and thereafter several substantial short-time loans were obtained from large banking institutions in other areas. These loans were sufficient to enable the association to advance members 40 per cent of the value of the tobacco delivered and to pay current expenses. So successfully had the financing of the advances for green tobacco been conducted during the first year that the association had no difficulty in subsequent years in obtaining adequate loans.

The large buying companies did not always pay immediately for tobacco bought from the association. But money was always necessary to meet the many obligations of the subsidiary warehousing corporations and the payments to members. When a sale was made to a tobacco buyer the letter of acceptance from such buyer was used as collateral for negotiating further loans. These loans were retired as soon as final settlement was made by the company.

Green tobacco delivered to the association was used as security for negotiating the loans with the different banks. The problem of securing title to the tobacco from the time it came into the possession of the association until it was sold or redried was a perplexing matter. An agreement was finally made between the loaning banks and the association whereby title to all green tobacco received was transferred to the American Trust Co. of Richmond. Each association warehouse was required to render daily a statement showing the quantity and grade of tobacco delivered and the amount of advances made thereon. These statements, supported by a list of detailed receipts, were filed with the American Trust Co. and held as security for the loans obtained. As loans were repaid out of the proceeds of sales of green tobacco an equivalent amount of this security was retired. The American Trust Co. made a charge for this service of one-fifteenth of 1 per cent in addition to the cost of the clerical labor involved.

A large part of the tobacco received was redried and shipped to bonded warehouses for storage. The finance committee of the association was able to complete an arrangement with the War Finance Corporation whereby the corporation agreed to make loans to the association practically without limit, but with the understanding 
that these loans were secured by redried tobacco stored in bonded warehouses. The loans obtained from the War Finance Corporation and the proceeds from sales of green tobacco were used to retire all the loans negotiated with the different commercial banks. This corporation further agreed to take title to, and finance, such tobacco as was not sold with reasonable dispatch. This undertaking was of the utmost value to the association as it obviated the forced sale of tobacco to secure ready funds.

In the face of keen opposition, the association was able to build up a satisfactory system of financing. During subsequent years, this system was not departed from in any essential respect. After the first year, the intermediate credit bank took the place of the War Finance Corporation and financed the redried tobacco in much the same manner. So great was the confidence created that at one time practically all the advances of the association were financed by one New York institution which loaned the association $\$ 5,000,000$ at very low rates of interest. The fact that the intermediate credit bank agreed to take over and finance such tobacco as could not be clisposed of immediately gave all the banks a feeling of confidence that they had a loan on a liquid commodity. Thereafter there was no difficulty in obtaining all the money needed at reasonably low rates of interest. $^{39}$

During the first year the association advanced 40 per cent of the value of the tobacco delivered. The initial advances were increased to 50 per cent in 1923 and 1924, and to 65 per cent in 1925 . Further payments were made as rapidly as possible from the proceeds of sales. Unfortunately, for reasons which will be explained later, a great deal of time elapsed before tobacco in the different pools could be disposed of and final payments made to members.

\section{COSTS OF OPERATION}

Operating, redrying, and other expenses of the association were studied in a general way to ascertain whether the association's operations were carried on with reasonable economy. Owing to the fact that tobacco in most of the pools had to be carried over from year to year, it was necessary to introduce a system of "accumulating" expense accounts whereby the expenses incurred in each year in the handling of the different pools were prorated to such pools. For example the dark-fired pool of the 1922 crop was charged with a proportionate part of the expenses incurred in 1922, '1923, 1924, and 1925. The great bulk of the expense in the handling of each pool was incurred in the year the tobacco was delivered. and the prorated expenses during subsequent years (except carrying charges) did not greatly add to the original expenses.

The accumulated expenses incurred in the operation of the various departments of the association and in redrying and carrying the tobacco in the various pools appear in Tables 49 to 53 in the ap-

3 The agricultural investigation commission found that money had been borrowed at rates ranging from not over 6 per cent to as low as $23 \%$ per cent; the average rate was below 5 per cent.

$76534-29-6$ 
pendix. A condensed statement of these expenses by years appears in Table 34. The expenses in this statement have been grouped under three headings: General overhead, carrying expenses, and redrying expenses. The general overhead expenses include the expenses of operating the different departments and a proportionate share of the organization expenses.

TABLE 34.-Condensed statement of operating expenses (all pools) as of May 31,1926

\begin{tabular}{|c|c|c|c|c|c|}
\hline Expense & 1922 crop & 1923 сrop & 1924 crop & 1925 crop & All crops \\
\hline $\begin{array}{l}\text { General overhead } 1 \\
\text { Carrying charges } \\
\text { Redrying charges }{ }^{2}\end{array}$ & $\begin{array}{c}\text { Dollars } \\
2,405,658.59 \\
415,673.74 \\
1,534,173.21\end{array}$ & $\begin{array}{c}\text { Dollars } \\
2,524,548.95 \\
1,011,190.32 \\
3,503,825.97\end{array}$ & $\begin{array}{c}\text { Dollars } \\
1,889,034.56 \\
591,353.55 \\
2,866,701.92\end{array}$ & $\begin{array}{c}\text { Dollars } \\
1,395.303,79 \\
191,724.85 \\
1,682,097.05\end{array}$ & $\begin{array}{l}\text { Dollars } \\
8,214,545.89 \\
2,209,942.46 \\
9,586,797.25\end{array}$ \\
\hline Total. & $4,355,505.54$ & $7,039,564.34$ & $5,347,090.03$ & $3,269,125.69$ & $20,011,285.60$ \\
\hline $\begin{array}{l}\text { Rate per } 100 \text { pounds of tobacco } \\
\text { received, green basis... }\end{array}$ & 2. 66 & 3.91 & 5.15 & 3. 91 & 3. 77 \\
\hline
\end{tabular}

1 The general overhead expenses include: (1) Head office expenses, (2) operating expense of warehouses, (3) expense of operating field service department, and (4) part of organization expenses.

2 The redrying expenses in 1924 and 1925 were charged with a part of the general overhead and warehouse operating expenses, which were not included in 1922 and 1923 . If these expenses had been charged to the general overhead expense as in 1922 and 1923, the amount charged to redrying in 1924 and 1925 would have been considerably reduced.

The total expenses, as of May 31, 1926, for the different years has been divided by the number of pounds of tobacco delivered to the association each year. The per 100-pound expenses increased each succeeding year except for the year 1925. Two factors account for the decrease in the cost per 100 pounds in this year. First, carrying charges on most of the 1925 crop of tobacco on hand at May 31, 1926, had accumulated for only a short period-less than six months for dark-fired and sun-cured tobacco. Second, the association did its own redrying in 1925 at a great reduction in cost. In 1924, redrying expenses on the basis of all the tobacco delivered amounted to $\$ 2.76$ per 100 pounds, whereas the redrying expenses for the deliveries of the 1925 crop were $\$ 2.01$, a reduction of $\$ 0.75$ per 100 pounds. On the basis of the tobacco actually redried in each of the two crops the saving in redrying expenses is even more apparent. The expense of redrying 83,384,000 pounds of the 1924 crop was $\$ 3.44$ per 100 pounds; the redrying expense for $70,816,000$ pounds of 1925 crop was $\$ 2.38$ per 100 pounds.

This indicates that the association made a saving of $\$ 1.06$ per 100 pounds in redrying the 1925 tobacco $^{40}$ as compared with the cost of redrying the 1924 crop.

Accumulated operating, carrying, and redrying expenses, allocated to the different pools, are shown in Table 35. In Table 36, for purposes of comparison, the expenses by years have been reduced to a per 100-pound basis. The general overhead expenses were reduced to a per 100-pound basis by dividing the total overhead

40 The comparison is not quite fair as part of the difference is due to higher storage charges for the 1924 crop. 
expenses for each pool by all the tobacco delivered in that pool. The redrying expenses were divided by the total quantity of tobacco redried (on a green basis) to get the cost per 100 pounds of redrying. The association allocated carrying charges to the different pools on a value basis. To ascertain the cost per 100 pounds of " carrying" tobacco it was first necessary to prorate the total carrying charges for each pool between redried tobacco sold and redried tobacco on hand at May 31, 1926, on a value basis. The carrying charges so prorated between sales and inventory were then divided by the weight of redried tobacco (on a green basis) ${ }^{t 1}$ actually sold.

The total expenses incurred in operating each pool were prorated between tobacco sold and inventory. The cost per 100 pounds of operation for each pool was obtained by dividing the expenses prorated to the tobacco sold by the weight (on a green basis) of tobacco sold in each pool.

TABLE 35.-Accumulated operating expenses to May 31, 1926, allocated to pools

\begin{tabular}{|c|c|c|c|c|c|}
\hline Pool & Type of expense & 1922 crop & 1923 crop & 1924 crop & 1925 crop \\
\hline \multirow[t]{2}{*}{ Sun-cured............... } & $\begin{array}{l}\text { General overhead. } \\
\text { Carrying charges.. } \\
\text { Redrying charges.. }\end{array}$ & \begin{tabular}{r}
\multicolumn{1}{c}{ Dollars } \\
$33,660.79$ \\
$4,971.26$ \\
$38,128.49$
\end{tabular} & \begin{tabular}{r}
\multicolumn{1}{c}{ Dollars } \\
$29,608.09$ \\
$5,417.74$ \\
$12,349.22$
\end{tabular} & $\begin{array}{r}\text { Dollars } \\
30,134.73 \\
334.39 \\
1,240.56\end{array}$ & $\begin{array}{r}\text { Dollars } \\
34.877 .25 \\
734.13 \\
2,597.85\end{array}$ \\
\hline & Tota & $76,760.54$ & $47,375.05$ & $31,709.68$ & $38,209.23$ \\
\hline \multirow[t]{2}{*}{ Dark-fired................ } & $\begin{array}{l}\text { General overhead. } \\
\text { Carrying charges.- } \\
\text { Redrying charges. }\end{array}$ & $\begin{array}{r}331,621.62 \\
55,533.68 \\
189,015.52 \\
\end{array}$ & $\begin{array}{l}316,589.63 \\
184,796.88 \\
406,881.24 \\
\end{array}$ & $\begin{array}{l}352,984.44 \\
130,091.38 \\
641,298.17 \\
\end{array}$ & $\begin{array}{r}246,158.51 \\
16,791.91 \\
210,987.77\end{array}$ \\
\hline & Total & $576,170.82$ & $908,267.75$ & $1,124,373.99$ & $473,938.19$ \\
\hline \multirow[t]{2}{*}{ Old belt............. } & $\begin{array}{l}\text { General overhead } \\
\text { Carrying charges.. } \\
\text { Redrying charges. }\end{array}$ & $\begin{array}{r}1,446,384.30 \\
265,203.43 \\
670,388.74 \\
\end{array}$ & $\begin{array}{r}1,279,031.24 \\
510,396.54 \\
1,691,982.08 \\
\end{array}$ & $\begin{array}{r}1,086,300.82 \\
352,040.28 \\
1,472,365.04 \\
\end{array}$ & $\begin{array}{r}507,306.44 \\
74,277.35 \\
657,247.49 \\
\end{array}$ \\
\hline & Total... & $2,381,976.47$ & $3,481,409.86$ & $2,910,706.14$ & $1,238,831.28$ \\
\hline \multirow[t]{2}{*}{ Eastern Carolina...... } & $\begin{array}{l}\text { General overhead } \\
\text { Carrying charges. } \\
\text { Redrying charges. }\end{array}$ & $\begin{array}{r}336,407.67 \\
61,603.48 \\
326,847.53 \\
\end{array}$ & $\begin{array}{l}411,506.73 \\
133,874.49 \\
612,702.04 \\
\end{array}$ & $\begin{array}{r}187,057.71 \\
54,978.34 \\
350,115.38 \\
\end{array}$ & $\begin{array}{r}149,370.67 \\
23,999.17 \\
177,691.51 \\
\end{array}$ \\
\hline & Tot: & $724,858.68$ & $1,158,083.26$ & $592,151.43$ & $351,061.35$ \\
\hline \multirow[t]{2}{*}{ South Carolina.......... } & $\begin{array}{l}\text { General overhead.. } \\
\text { Carrying charges.- } \\
\text { Redrying charges.. }\end{array}$ & $\begin{array}{r}257,584.21 \\
28,361.89 \\
309,792.93\end{array}$ & $\begin{array}{l}487,813.26 \\
176,704.67 \\
779,910.49\end{array}$ & $\begin{array}{r}232,556.86 \\
53,909.16 \\
401,682.77 \\
\end{array}$ & $\begin{array}{r}457,590.92 \\
75,922.29 \\
633,572.43\end{array}$ \\
\hline & Total. & $595,739.03$ & $1,444,428.42$ & $688,148.79$ & $1,167,085.64$ \\
\hline
\end{tabular}

41 The following formula was used:

Cost per 100 pounds of $\begin{aligned} & \text { Cost per } 100 \text { pounds of } \\ & \text { carrying redried tobacco }\end{aligned}=\frac{\text { Value of redried tobacco sold }}{\text { Value of redried tobacco sold plus value of }} \times \frac{\text { Carrying charges }}{\text { Amount of redried }}$ $\begin{aligned} & \text { Cost per } 100 \text { pounds of } \\ & \text { carrying redried tobacco }\end{aligned}=\frac{\text { Value of redried tobacco sold }}{\text { Value of redried tobacco sold plus value of }} \times \frac{\text { Carrying charges }}{\text { Amount of redried }}$ (green basis)
inventory tobacco 
TABLE 36.-Expenses of operating poots per 100 pounds of tobacco

\begin{tabular}{|c|c|c|c|c|}
\hline Expense and pool & 1922 стор & 1923 crop & 1924 crop & 1925 crop \\
\hline $\begin{array}{l}\text { General overhead (all tobacco): } \\
\text { Sun-cured } \\
\text { Dark-fired } \\
\text { Old-belt } \\
\text { Eastern Carolina } \\
\text { South Carolina }\end{array}$ & $\begin{array}{r}\text { Dollars } \\
0.94 \\
1.24 \\
1.61 \\
1.45 \\
1.29\end{array}$ & $\begin{array}{r}\text { Dollars } \\
0.98 \\
1.31 \\
1.40 \\
1.53 \\
1.41\end{array}$ & $\begin{array}{r}\text { Dollars } \\
1.42 \\
1.75 \\
1.86 \\
1.98 \\
1.69\end{array}$ & $\begin{array}{r}\text { Dollars } \\
1.77 \\
1.70 \\
1.47 \\
2.14 \\
1.79\end{array}$ \\
\hline $\begin{array}{l}\text { Redrying expense (redried tobacco): } 1 \\
\text { Sun-cured } \\
\text { Dark-fired } \\
\text { Old-belt } \\
\text { Eastern Carolina } \\
\text { South Carolina }\end{array}$ & $\begin{array}{l}2.46 \\
3.12 \\
2.85 \\
3.11 \\
3.21\end{array}$ & $\begin{array}{l}\text { 3. } 04 \\
3.51 \\
2.84 \\
3.02 \\
3.29\end{array}$ & $\begin{array}{l}2.70 \\
\text { 3. } 56 \\
\text { 3. } 23 \\
\text { 3. } 89 \\
3.72\end{array}$ & $\begin{array}{l}2.36 \\
2.15 \\
2.15 \\
2.86 \\
2.63\end{array}$ \\
\hline $\begin{array}{l}\text { Carrying charges (redried tobacco): } \\
\text { Sun-cured } \\
\text { Dark-fired } \\
\text { Old-belt } \\
\text { Eastern Carolina. } \\
\text { South Carolina }\end{array}$ & $\begin{array}{r}.32 \\
.92 \\
1.13 \\
.59 \\
.29\end{array}$ & $\begin{array}{r}1.33 \\
1.58 \\
.86 \\
.66 \\
.75\end{array}$ & $\begin{array}{l}.72 \\
.65 \\
.77 \\
.61 \\
.50\end{array}$ & $\begin{array}{l}.07 \\
.17 \\
.24 \\
.39 \\
.32\end{array}$ \\
\hline $\begin{array}{l}\text { All operating (on tobacco sold): } \\
\text { Sun-cured } \\
\text { Dark-fired. } \\
\text { Old-belt } \\
\text { Eastern Carolina } \\
\text { South Carolina }\end{array}$ & \begin{tabular}{l|}
2.14 \\
2.05 \\
2.54 \\
2.70 \\
2.98
\end{tabular} & $\begin{array}{l}1.57 \\
2.68 \\
3.75 \\
3.45 \\
4.18\end{array}$ & $\begin{array}{l}1.50 \\
\text { 4. } 98 \\
\text { 4. } 63 \\
6.26 \\
4.98\end{array}$ & $\begin{array}{l}1.77 \\
1.82 \\
2.34 \\
4.86 \\
4.56\end{array}$ \\
\hline
\end{tabular}

1 See footnote 2, Table 34, p. 82.

It was not possible to analyze these expenses in detail. Attention is drawn to certain outstanding facts. The great bulk of this general overhead and redrying expenses for any one crop were incurred in the year in which tobacco was received. It is thus possible to draw a comparison between the expenses incurred during the different years and, to a more limited extent, to compare these costs for the different pools. Redrying was the most important item of expenditure. The effect of the redrying expense on the total operating expenses depends upon the total quantity of tobacco redried in in each pool. In 1922, only 31.4 per cent of the tobacco received was redried. As a result the total operating expenses for that year were much lower in proportion to the receipts of tobacco than they were for later years.

The total operating expenses were lower for the sun-cured pools than they were for the other pools because the bulk of the sun-cured tobacco was sold in the green state. This reduced the total cost both of redrying and of carrying the tobacco. On the other hand, the operating expenses were very heavy for the pools in years in which a large proportion of the tobacco was redried. The year 1924 is an example. During that year over 80.3 per cent of the tobacco received was redried, and the operating expenses for that year were extremely heavy in all except the sun-cured pool.

The per 100-pound cost of operation, especially in the field of general overhead expenses, increased as the volume of receipts decliner. In 1923, the quantity of tobacco received in the flue-cured pools was somewhat larger than in 1922. A decline in overhead expenses is noted for the eastern Carolina and old-belt pools. Provision was made for a greater delivery in South Carolina in 1923, but as this did not materialize the expenses for that year were higher than they were for 1922. After 1923 the general orerhead expenses increased for nearly every pool. However, there was a substantial reduction in these expenses for the old-belt pool for 1925, and a smaller reduction for the dark-fired pool for that year, resulting 
chiefly from economies in the operation of the old-belt and dark-fired warehouses. The difference between the share of general overhead expenses of the different pools was due to the fact that expenses were prorated to the pools on a basis of both weight and value.

The total redrying expenses also tended to increase not only actually but relatively as larger proportions of each crop were redried. In 1923, more than twice as much tobacco was redried as in 1922. The actual expense per 100 pounds of redrying was the same ( $\$ 1.64$ on a green basis $)^{42}$ but some of the other expenses included in the redrying, notably freight to storage warehouses and sampling and recoopering, more than trebled. The total redrying expenses were also increased by the inclusion of a charge for labor needed to handle redried tobacco. This charge was not included in 1922, having evidently been charged to general overhead expenses. In 1924, in spite of the fact that the Edmondson Tobacco Co., in which two of the association's executive officers were interested, reduced its redrying charges to $\$ 1.50$ per 100 pounds, the total cost of redrying alone remained at $\$ 1.64$. In 1925 , when the association did its own redrying, the cost of redrying only was reduced to 98 cents per 100 pounds on the green basis-a reduction of 66 cents.

Carrying charges per 100 pounds depended upon the quantity and value of tobacco that was redried and the length of time it was stored. The carrying charges were heaviest for the pools in which large quantities of tobacco were redried and stored for a considerable length of time. The carrying charges per 100 pounds for the 1925 crop were small because most of the 1925 tobacco had been stored for only a few months at the time of the receivership.

In North Carolina and South Carolina the warehouse charges on tobacco sold for farmers on the auction floor are fixed by law. The following charges were in effect during the four years that the association was in operation:

Weighing charges: 10 cents per lot of 100 pounds or portion thereof with a minimum charge of 10 cents per lot.

Auction charges: 15 cents per lot of 100 pounds (minimum 15 cents); 25 cents per lot of 200 pounds or more.

Commission $2 \frac{1}{2}$ per cent of gross proceeds of sale.

A questionnaire was addressed to warehouse operators in Virginia to ascertain the cost of selling tobacco under the auction-floor system of marketing during the years 1922 to 1925 . In Virginia, warehouse charges are fixed by the tobacco board of trade in the different marketing centers, and some variation is apparent. In most of the large marketing centers the warehouse charges are the same as they are in North Carolina and South Carolina. In some of the smaller markets a flat charge is made to include all services, but as a rule this amount did not vary greatly from the charges above enumerated. At Richmond, where the bulk of the sun-cured tobacco is sold, the variation in the charges is of some importance. A weighing charge of 15 cents and an auction fee of 25 cents is deducted from every pile of tobacco sold, regardless of weight. In addition, a commission of 3 per cent is deducted from the gross proceeds of the sale.

The cost of marketing 100 pounds of tobacco sold, based on the average price prevailing in the different areas under the auction-floor

42 Obtained by dividing the total cost of redrying only (exclusive of storage and other charges) by the weight of tobacco redried (on a green basis). See detailed redrying expense account in appendix Table 4. 
system of marketing, is shown in Table 37. The average costs would be somewhat higher than these because a great deal of tobacco is sold in lots of less than 100 pounds for which minimum weighing and auction charges are levied. As the commissions are a percentage of the gross price, the deductions made in this table are only approximately correct, but for the purpose of comparison these figures are fairly satisfactory.

The purpose of obtaining the cost of selling under the auctionfloor system was not to compare it with the costs under the cooperative but for the purpose of obtaining the arerage net amount paid to the growers under the two systems. Comparisons between the expense of marketing tobacco through a cooperative association and through an auction-floor warehouse are of little significance because the two methods do not render comparable services.

TABLE 37.-Estimated cost of selling 100 pounds of tobacco under the auctionfloor system

\begin{tabular}{|c|c|c|c|c|c|}
\hline Area & Charge & $\begin{array}{l}1922 \\
\text { crop }\end{array}$ & $\begin{array}{l}1923 \\
\text { crop }\end{array}$ & $\begin{array}{l}1924 \\
\text { crop }\end{array}$ & $\begin{array}{l}1925 \\
\text { crop }\end{array}$ \\
\hline \multirow[t]{2}{*}{ Sun-cured (Richmond market) } & $\begin{array}{l}\text { Weighing fee } \\
\text { Auction fee } \\
\text { Commission at } 3 \text { per cent of gross sell- } \\
\text { ing value... }\end{array}$ & $\begin{array}{c}\text { Dollars } \\
0.15 \\
.25 \\
.43\end{array}$ & $\begin{array}{c}\text { Dollars } \\
0.15 \\
.25 \\
.40\end{array}$ & $\begin{array}{c}\text { Dollars } \\
0.15 \\
.25 \\
.44\end{array}$ & $\begin{array}{r}\text { Dollars } \\
0.15 \\
.25 \\
.49\end{array}$ \\
\hline & Total_. & .83 & .80 & .84 & .89 \\
\hline \multirow[t]{2}{*}{ Dark-fired............ } & $\begin{array}{l}\text { Weighing fee } \\
\text { Auction fee } \\
21 / 2 \text { per cent commission }\end{array}$ & $\begin{array}{l}.10 \\
.15 \\
.49\end{array}$ & $\begin{array}{l}.10 \\
.15 \\
.45\end{array}$ & $\begin{array}{l}.10 \\
.15 \\
.49\end{array}$ & $\begin{array}{l}.10 \\
.15 \\
.41\end{array}$ \\
\hline & Total & .74 & .70 & .74 & .66 \\
\hline \multirow[t]{2}{*}{$\begin{array}{l}\text { Old belt (old-belt area of North } \\
\text { Carolina and Virginia). }\end{array}$} & $\begin{array}{l}\text { Weighing fee } \\
\text { Auction fee- } \\
21 / 2 \text { per cent commission }\end{array}$ & $\begin{array}{l}.10 \\
.15 \\
.76\end{array}$ & $\begin{array}{l}.10 \\
.15 \\
.54\end{array}$ & $\begin{array}{l}.10 \\
.15 \\
.54\end{array}$ & $\begin{array}{l}.10 \\
.15 \\
.43\end{array}$ \\
\hline & Total.... & 1.01 & .79 & .79 & .68 \\
\hline \multirow[t]{2}{*}{$\begin{array}{l}\text { North Carolina (new-belt area } \\
\text { equal to eastern Carolina } \\
\text { pool). }\end{array}$} & $\begin{array}{l}\text { Weighing fee } \\
\text { Auction fee } \\
21 / 2 \text { per cent commission. }\end{array}$ & $\begin{array}{l}.10 \\
.15 \\
.74\end{array}$ & $\begin{array}{l}.10 \\
.15 \\
.60\end{array}$ & $\begin{array}{l}.10 \\
.15 \\
.64\end{array}$ & $\begin{array}{l}.10 \\
.15 \\
.64\end{array}$ \\
\hline & ' Total $_{\text {... }}$ & .99 & .85 & .89 & .89 \\
\hline \multirow[t]{2}{*}{ South Carolina (new belt)..... } & $\begin{array}{l}\text { Weighing ree } \\
\text { Auction fee } \\
\text { Commission at } 21 / 2 \text { per cent of gross } \\
\text { selling value............................... }\end{array}$ & $\begin{array}{r}.10 \\
.15 \\
.58\end{array}$ & $\begin{array}{l}.10 \\
.15 \\
.48\end{array}$ & $\begin{array}{l}.10 \\
.15 \\
.44\end{array}$ & $\begin{array}{l}.10 \\
.15 \\
.42\end{array}$ \\
\hline & Total.. & .83 & .73 & .69 & .67 \\
\hline
\end{tabular}

The charges per 100 pounds of handling tobacco by pooling areas under the cooperative and auction-floor system is summarized in Table 38. The association's charges were considerably higher in every case, as would be expected because of the many additional services rendered. The differences in the charges were greatest for the 1924 crop. Included in the association's charges of marketing 100 pounds of its members' tobacco was the cost of redrying and storing, for which no similar charge was included under the auction-floor system.

It would perhaps be more equitable to compare the general overhead charges only, or the charges of selling only, of the association with the charges for marketing tobacco under the auction-floor system. Such a comparison is made in Table 38. Even on this basis, the costs of operation through the association were much 
higher to the grower, and tended to increase during the last three years as deliveries of tobacco decreased. But even on this basis it must be kept in mind that the association was rendering services to its members and to the tobacco companies that are not given by the auction-floor warehouses. The differences in the charges were least in the case of sun-cured tobacco; the services given by the association were made at less cost because of the comparatively easy and quick sale in the green state of most of the tobacco of this pool.

The legal expense incurred in attempts to enforce the membership contract was a large item of cost. During the four years, $\$ 367,862.14$ was spent in legal expenses. To offset this expense, $\$ 165,030.33$ was collected from members as liquidated damages and expenses. Collection of this sum, although a source of some income, was harmful, as it merely served to aggravate the dissatisfaction among members. According to a statement issued by the receivers, $\$ 295,767.03$ was paid to attorneys and legal counsel during the four years the association was in operation. The net legal expense for the four years, the legal expenses less the liquidated damages collected, was over $\$ 200,000$; half of this was incurred on the 1923 crop.

TABLE 38.- Selling charges under the auction-floor system compared with the selling charges of the association and deductions for all handling charges made by the association, 1922-1926

\begin{tabular}{|c|c|c|c|c|c|}
\hline Area (pool) & System and kind of charge made & $\begin{array}{l}1922 \\
\text { crop }\end{array}$ & $\begin{array}{l}1923 \\
\text { crop }\end{array}$ & $\begin{array}{l}1924 \\
\text { crop }\end{array}$ & $\begin{array}{l}1925 \\
\text { crop }\end{array}$ \\
\hline \multirow[t]{3}{*}{ Sun-cured ....................... } & Auction floor & $\begin{array}{c}\text { Dollars } \\
0.83\end{array}$ & $\begin{array}{c}\text { Dollars } \\
0.80\end{array}$ & $\begin{array}{c}\text { Dollars } \\
0.84\end{array}$ & $\begin{array}{r}\text { Dollars } \\
0.89\end{array}$ \\
\hline & $\begin{array}{l}\text { Association: } \\
\text { Selling only } 1 . . . \\
\text { All handling }{ }^{2}-\end{array}$ & $\begin{array}{r}.94 \\
2.14 \\
\end{array}$ & $\begin{array}{r}.98 \\
1.57 \\
\end{array}$ & $\begin{array}{l}1.42 \\
1.50 \\
\end{array}$ & $\begin{array}{l}1.77 \\
1.77 \\
\end{array}$ \\
\hline & $\begin{array}{l}\text { Difference in charges: } \\
\text { Selling only } \\
\text { All handling...... }\end{array}$ & $\begin{array}{r}.11 \\
1.31 \\
\end{array}$ & $\begin{array}{l}.18 \\
.77 \\
\end{array}$ & $\begin{array}{r}.58 \\
.66 \\
\end{array}$ & $\begin{array}{l}.88 \\
.88 \\
\end{array}$ \\
\hline \multirow{3}{*}{ Dark-fired........................ } & Auction floor & .74 & .70 & .74 & .66 \\
\hline & $\begin{array}{l}\text { Association: } \\
\text { Selling only }{ }^{1--} \\
\text { All handling }{ }^{2}-\end{array}$ & $\begin{array}{l}1.24 \\
2.05 \\
\end{array}$ & $\begin{array}{l}1.31 \\
2.68\end{array}$ & $\begin{array}{l}1.74 \\
4.98\end{array}$ & $\begin{array}{l}1.70 \\
1.82\end{array}$ \\
\hline & $\begin{array}{l}\text { Difference in charges: } \\
\text { Selling only } \\
\text { All handling...... }\end{array}$ & $\begin{array}{r}.50 \\
1.31\end{array}$ & $\begin{array}{r}.61 \\
1.98\end{array}$ & $\begin{array}{l}1.00 \\
4.24\end{array}$ & $\begin{array}{l}1.04 \\
1.16 \\
\end{array}$ \\
\hline \multirow[t]{3}{*}{ Old-belt_............................ } & $\begin{array}{l}\text { Auction floor } \\
\text { Association: }\end{array}$ & 1.01 & .79 & .79 & .68 \\
\hline & $\begin{array}{l}\text { Selling only }{ }^{1} \text { - } \\
\text { All handling }{ }^{2}-\end{array}$ & $\begin{array}{l}1.61 \\
2.54 \\
\end{array}$ & $\begin{array}{l}1.40 \\
3.75 \\
\end{array}$ & $\begin{array}{l}1.86 \\
4.63 \\
\end{array}$ & $\begin{array}{l}1.46 \\
2.34 \\
\end{array}$ \\
\hline & $\begin{array}{l}\text { Difference in charges: } \\
\text { Selling only } \\
\text { All handling }\end{array}$ & $\begin{array}{r}.60 \\
1.53 \\
\end{array}$ & $\begin{array}{r}.61 \\
2.96 \\
\end{array}$ & $\begin{array}{l}1.07 \\
3.84 \\
\end{array}$ & $\begin{array}{r}.78 \\
1.66 \\
\end{array}$ \\
\hline \multirow[t]{3}{*}{ Eastern Carolina } & Auction floor............... & .99 & .85 & .89 & .89 \\
\hline & $\begin{array}{l}\text { Selling only }{ }^{1} \\
\text { All handling }\end{array}$ & $\begin{array}{l}1.45 \\
2.70 \\
\end{array}$ & $\begin{array}{l}1.41 \\
3.45 \\
\end{array}$ & $\begin{array}{l}1.98 \\
6.26\end{array}$ & $\begin{array}{l}2.14 \\
4.86 \\
\end{array}$ \\
\hline & $\begin{array}{l}\text { Difference in charges: } \\
\text { Selling only } \\
\text { All handling...... }\end{array}$ & $\begin{array}{r}.46 \\
1.71 \\
\end{array}$ & $\begin{array}{r}.56 \\
2.60 \\
\end{array}$ & $\begin{array}{l}1.09 \\
5.37 \\
\end{array}$ & $\begin{array}{l}1.25 \\
3.97 \\
\end{array}$ \\
\hline \multirow[t]{3}{*}{ South Carolina..................... } & $\begin{array}{l}\text { Auction floor } \\
\text { Association: }\end{array}$ & .83 & .73 & .69 & .67 \\
\hline & $\begin{array}{l}\text { Selling only }{ }^{1} \\
\text { All handling }{ }^{2}--\end{array}$ & $\begin{array}{l}\text { 1. } 29 \\
\text { 2. } 98 \\
\end{array}$ & $\begin{array}{l}1.41 \\
4.18 \\
\end{array}$ & $\begin{array}{l}1.69 \\
4.98 \\
\end{array}$ & $\begin{array}{l}1.79 \\
4.56 \\
\end{array}$ \\
\hline & $\begin{array}{l}\text { Difference in charges: } \\
\text { Selling only } \\
\text { All handling }\end{array}$ & $\begin{array}{r}.46 \\
2.15\end{array}$ & $\begin{array}{r}.68 \\
3.45\end{array}$ & $\begin{array}{l}1.00 \\
4.29\end{array}$ & $\begin{array}{l}1.12 \\
3.89\end{array}$ \\
\hline
\end{tabular}

1 General overhead charges only, excluding redrying and carrying. See also footnote 2, Table 34, p. 82 .

2 Includes all charges made on members' tobacco except the deductions for purchase of warehouse property and for reserves. 
Despite the fact that it rendered new and additional services to both its members and its patrons there can be no doubt that the Tobacco Growers' Cooperative Association was operated on an uneconomical and extravagant basis. On tobacco valued at $\$ 100,480$,514.46 at the time of its receipt, according to the bankers' valuation, and on sales of $\$ 98,186,272.70$, the total general overhead expenses were $\$ 8,214,545.99$. The carrying charges totaled $\$ 2,209,942.60$. 'The redrying expenses (which as a step in its processing should enhance the value of the tobacco redried by an equal amount) were $\$ 9,586,797.25$ or 47.9 per cent of the total of all expenses of $\$ 20,011,285.60$.

These figures show the high cost of handling and selling tobacco through the Tobacco Growers' Cooperative Association of Virginia and the Carolinas but they also show the possibility of economical handling of tobacco if it can be sold cooperatively in large volumes and if the costs of carrying, redrying, or other processing can be added to the price in the green state. It must be borne in mind that the general overhead expenses in the case of this association cover the costs of a number of services not included in those given by the looseleaf auction system to the growers or to the purchasers. as well as the unwarranted costs of some extravagances.

In regard to the total expenses the receivers said in their statement on the mismanagement of the association:

The management is entitled in a statement of this character to credit for redrying cost of tobacco on hand at the time of the receivership. This would reduce the total expense figure to about $\$ 17,000,000$, or a cost ratio of over 17 per cent on the total sales. These figures reflect the serious mistakes in management, the too great outlay in the purchase of warehouse properties, the maintenance of a pay roll disproportionate to the volume of business, the failure to adjust the expenses of operation to tobacco receipts which should have been radically scaled down consistent with their actual experiences in procuring membership tobacco, which from the above figures amounted to only about one-third of the contract sign up; and the discreditable redrying policy. No cooperative dealing with tobacco can hope to achieve permanent good to its members, or win their support and confidence, upon such an unbusinesslike ratio between sales and expenses. This one comparison alone fully explains the failure of the association.

DEDUCTIONS FOR RESERVES

The costs of operation, the overhead, and the reserves, were deducted from the sales price of the tobacco. A reserve for contingencies was computed on the basis of 1 per cent of the gross sale value of receipts, on the green basis. Overpayments to members on closed pools were charged to this reserve by pools, according to the resolution of the board of directors to that effect. At June 19, 1926, the reserve set up on closed pools amounted to $\$ 623,707.77$, against which overpayments to members amounting to $\$ 404,326.03$ and sundry expenses and excess values given to closed grades over the actual sales price of $\$ 141,728.22$, reduced the reserve to $\$ 77,653.52$ on the association books. ${ }^{43}$

\section{PRICE AND SALES POLICY}

Before describing the manner in which sales were made and the sales policies adopted by the association, it may be advisable to 
recapitulate briefly the conditions under which the association was operating, for these conditions largely determined the policies that the directors saw fit to adopt. The organizers of the association hoped that ultimately the cooperative system of marketing tobacco would displace the existing auction-floor system. It was the intention of the board to deal directly with the large domestic tobacco companies as far as possible and eventually to establish direct connections with foreign companies and Government monopolies. Because tobacco is subject to rapid deterioration, members were forced to deliver their tobacco to the association within a period of a few weeks whereas the association had to attempt to dispose of this tobacco to the large companies at such times and places as would best suit large companies. These companies bought only a part of the crop in the green state. Therefore, since to avoid dumping of the tobacco of its members upon the market during the course of a few weeks was one of the purposes of the association, it was necessary to make arrangements for the immediate redrying, financing, and storing of the remainder until such times as the tobacco companies were prepared to purchase it.

BANKERS' VALUATION COMMITTEES

It has already been shown that in the establishment and operation of its grading system the association succeeded in materially correcting one of the chief complaints against the auction-floor system of marketing, namely, the discrimination and inequalities in prices paid to different growers for the same quality of tobacco. But the main problem confronting the association was to obtain for its members an average price for their tobacco justified by conditions of demand and supply. It had previously been maintained by some agricultural leaders and farmers that the large tobacco companies, owing to their dominant position in the market, were able to force farmers to accept a price below what market conditions would justify. The board of directors, then, was obliged to devise some means of ascertaining what was an equitable price or what average price would be justified by conditions of demand and supply. So many immeasurable forces affect the ultimate price of tobacco that at best even an estimate of a reasonable average price for the crop as a whole was a matter of guesswork.

Few reliable figures were available on the factors affecting the prices of tobacco generally, or the prices of tobacco by types or quality. Practically no research work in tobacco prices had been done by either Federal or State agencies which might aid the board, the bankers' valuation committee, or the sales committee, in arriving at fair and warranted prices. But to arrive at an average price for the crop as a whole was only part of the task.

Before receiving the members' tobacco, one of the first acts of the association each season was to determine the price which each grade of tobacco could be expected to bring in order to give the grower as advance payment upon delivery a certain percentage of an estimated value.

To pay members according to quality, it was necessary to have not only an average price for each crop as a whole, but also a range of prices for several hundred grades of tobacco. These prices had 
to be so graduated that the average price paid on all the grades of tobacco would equal the estimated average price which, it was believed, market conditions justified. To complicate the matter further, the association operated five different pools covering three different classes, including five types of tobacco for which the conditions of supply and demand were different.

There were indications of an increasing demand for the flue-cured variety of tobacco, whereas for Virginia dark-fired and sun-cured tobacco the demand had been steadily decreasing. Moreover, not all grades of flue-cured tobacco were suitable for cigarette manufacture and there was a danger that if too high minimum prices were placed on these grades the association would not be able to dispose of them. This is what actually happened.

The purposes of having a tentative price set upon each grade of tobacco to be received by the association were three: (1) As a basis for advances to members, (2) as a basis of loans from banks, and (3) as a basis for the sales price to the tobacco dealers and manufacturers.

Funds to pay the advances to the members had to be obtained from the banks. As the loans from the banks were made upon the delivered tobacco as collateral, an appraisal of this tobacco had to be made by independent and disinterested tobacco experts. Some arbitrary method had to be adopted to determine the prices of each of the different grades of tobacco. For this purpose, committees of independent leaf dealers known as the bankers' valuation committee were appointed by the loaning banks with the approval of the War Finance Corporation and later of the Intermediate Credit Bank of Baltimore.

These committees, three in number (one each for the sun-cured, dark-fired, and the three flue-cured pools) were usually composed of three men each appointed for one year. These men were not connected with nor employed by the association, but the association paid their expenses. Some of the members were on more than one committee at times. With one exception, there was no complete change of personnel on any committee from one year to the next, but there was a continual change in membership of all committees except in those representing the dark-fired and sun-cured pools from 1923 to 1924. Only one member of the three committees served for the entire four years of operation.

Each year, before the tobacco markets opened, the bankers' valuation committee for each type of tobacco collected information on market conditions, such as quantity and quality of tobacco, stocks of leaf tobacco on hand, foreign conditions, and any other factors affecting the demand and supply for tobacco. On the basis of this information, and guided by their past experience in the auction-floor system of marketing, the members of this committee decided upon what they considered a reasonable and conservative average price for tobacco.

On the basis of this average price, separate schedules of prices were drawn up for the different grades of tobacco in the five pools. As these schedules were drawn up chiefly as the basis for loaning money to the association for advances to members, the prices were probably conservative. Even if the prices placed upon the different grades were too high, the loaning banks were amply secured, as loans 
to the association were restricted to a percentage of the "bankers' valuation." In Table 54 (appendix) is shown the total quantity of tobacco received from members each year and the value placed upon such tobacco by the bankers' valuation committee. When a member delivered his tobacco to an association warehouse, it was immediately graded, and he was given an advance payment based on the grade and weight of his tobacco. This advance payment was made on a percentage basis: 40 per cent of the bankers' valuation the first year, 50 per cent the second and third years, and 65 per cent the last year. The members were then issued participation receipts (or P. C.'s) showing the quantities and grades of tobacco delivered.

SALES COMMITTEES

The most difficult phase of the leaf department's activity was the selling of the tobacco delivered to the association. This department was divided into two subdepartments, the bright leaf and the dark leaf, each with a separate and independent general manager, who was responsible directly to the executive committee. The selling of the bright leaf and the dark leaf was entrusted to the general manager of each subdepartment originally, but upon the death of the manager of the dark-leaf department no successor was appointed, so both of these sections came under the direction of the general manager of the bright-leaf department. Sales committees composed of members of the board of directors were appointed to assist and advise the general managers. All sales had to have the sanction of this committee, but in practice virtually the full burden and responsibility of making sales fell upon the general managers of the two subdepartments, as their recommendations to the sales committees were usually affirmed.

\section{POLICIES}

It was the opinion of the leaders of the association that success was contingent upon obtaining a dominant position in the market by controlling at least 50 per cent of the crop. When the association was formed in February, 1922, the members had contracted to deliver (on the basis of the crop of 1920) over $350,000,000$ pounds of tobacco, or about 52 per cent of the crop. By the time the association was ready to take delivery of the $1922 \mathrm{crop}$, nearly 16,000 more members had been obtained and control was thereby extended presumably to about 60 per cent of the crop. By the end of the first crop year about 8,000 more members had been obtained, bringing the volume supposedly controlled to nearly 70 per cent.

The ultimate objective of the formation of the Tobacco Growers' Cooperative Association was to bring about improvements in the marketing of tobacco that would result in higher returns to members. The association might have brought this about in one or all of four ways: (1) By obtaining more uniform, stable, and just prices for the same grade and quality of tobacco through sales of members' tobacco, directly to the manufacturers, in large volumes; (2) by improving the marketing organization so as to insure greater economy in the handling and the processing of tobacco; (3) by performing certain services for members which result in a saving of time and 
money; and (4) by aiding the farmer to produce a better quality of tobacco or a type better suited to meet the market demand, or by aiding him to produce tobacco at a lower cost.

It is the purpose now to analyze the price and sales policies of the Tobacco Growers' Cooperative Association in order to ascertain to what extent it succeeded in performing any or all of the above services.

There is no record or information available that the organizers of the Tobacco Growers' Cooperative Association ever formulated any detailed sales policy. They had in mind certain broad general principles, but probably nerer prepared any definite method of procedure. All were agreed that one of the association's main objects was to aroid the annual dumping of tobacco in the market during a short marketing season. If the association controlled a large portion of the annual production, its officials believed that they would then be in a strong position to bargain with the large tobacco companies. It was hoped that ultimately all middlemen and leaf dealers would be displaced and that the association would thus be able to deal directly with both domestic and foreign companies. In other words, the association's objective was erentually to effect a radical change in which the auction-floor system of marketing was to be displaced.

It was felt that the success of the association was absolutely dependent upon the association's obtaining control over an appreciable portion of the annual tobacco crop. But another factor of prime importance had to be taken into account-the opposition that such a policy would provoke. It was inevitable that neither the representatires of the tobacco manufacturers nor the independent leaf dealers would submit without protest to this movement, which, if successful, would erentually deprive them of their business.

It would appear that the sales committee of the association, in placing minimum sales prices upon the different grades of green tobacco, was largely guided by the schedules of prices prepared by the bankers' valuation committee. It was understood, from the former general manager of the bright-leaf department, that the reserve prices placed upon green tobacco were based upon the bankers' raluation prices, plus a proportionate amount of the estimated cost of operation per pound. Whenever conditions justified such action, green tobacco was sold for prices in excess of this reserve price, but never below. All tobacco that could not be sold at the green reserve price within a few days after delivery was immediately consigned to a redrying plant. Attention is again called to the fact that tobacco in the green state is subject to rapid deterioration unless it is frequently turned to prevent overheating. Only a few days, therefore, were available for selling tobacco in the green state after is was delivered.

The officials in charge of the various association warehouses were required to advise the leaf department dailv of the quantity of each grade of tobacco delivered by members. This department was thus at all times in possession of accurate information as to the volume of each grade of tobacco available at the different receiring points within each pooling area. The selling force of the leaf department kept in constant touch with the buying departments of the different tobacco companies and leaf dealers, and sales were negotiated whenever a satisfactory price could be arranged. 
During the first two years 1922-23 and 1923-24 tobacco was sold in the green state to any buyer who was prepared to pay the price demanded by the association. During the last two years, the association adopted the policy of selling tobacco in the green state only to the large manufacturing companies, or to leaf dealers who could show that they were buying on order for some domestic manufacturing company or foreign buyer. The reason advanced for the adoption of this policy was that several leaf dealers, after purchasing green tobacco from the association, subsequently resold such tobacco on the open auction warehouse floors. ${ }^{44}$ Whenever higher prices were obtained for such resales, the figures were given wide publicity. There was so much criticism of this practice that upon petition it was decided to discontinue sales of green tobacco to leaf dealers. Attention should be drawn to the fact that this policy was in line with the

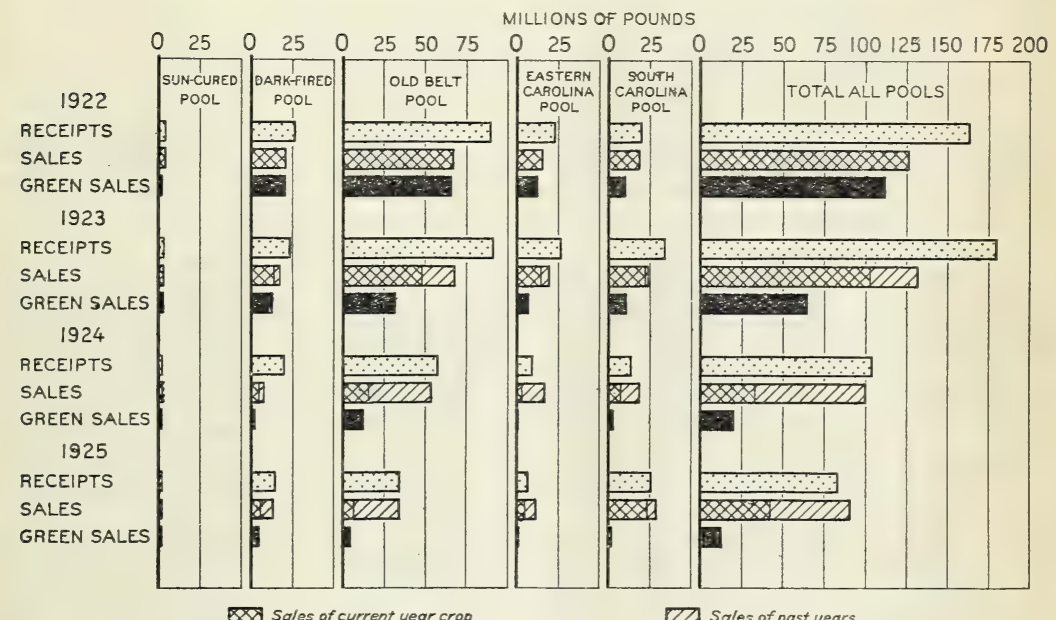

Figure 16.-Association Receipts, SALEs, and SAles of Green Tobacco BY POOLS, 1922-1925

From 68.6 per cent of the total association receipts of tobacco of the 1922 crop sold in the green state the proportion of green sales to receipts fell to 35.9 per cent in 1923 , to $\mathbf{1 9 . 7}$ per cent in 1924 , and to 15.3 per cent in 1925 .

plans of the association ultimately to deal directly with the large manufacturing and exporting companies.

This was an unfortunate decision on the part of the board, for it served not only to prevent many sales and to delay payments to members, but to aggravate an already intense opposition from leaf dealers. Possibly this decision also made it somewhat easier for those officers connected with the redrying of tobacco to justify the larger quantities of tobacco that it was found necessary to redry. Undoubtedly this policy proved advantageous to the large tobacco companies, for the association was forced to store a larger percentage of redried tobacco on which the prices realized eventually were in

44 This complaint originated in the dark-fired belt and the dark-fired tobacco was the first authorized to be redried before sold. 
nearly all cases somewhat below the green prices plus redrying and carrying charges. This matter will be referred to later.

Table 39 and Figure 16 show the quantity and percentage of tobacco (all pools) sold in the green state during the four years the association was in operation. Sixty-eight and six-tenths per cent of the tobacco of the 1922 crop delivered to the association was sold in the green state. During the next year the proportion fell to 35.9 per cent, while for the 1924 and 1925 crops the green sales were 19.7 per cent and 15.3 per cent, respectively, of the quantity delivered. It would appear that practically all the sun-cured tobacco was sold as green tobacco each year. This was due to the fact that the bulk of this type of tobacco was purchased by only one company, which apparently preferred to obtain its tobacco in this state. In most of the other pools an increasingly larger percentage was redried annually.

\section{TABLE 39.-Receipts and sales of green tobacco (all pools)}

\begin{tabular}{|c|c|c|c|c|c|c|c|}
\hline Crop and pool & $\begin{array}{c}\mathrm{Re}- \\
\text { ceipts }\end{array}$ & $\begin{array}{c}\text { Sales } \\
\text { of green } \\
\text { tobacco }\end{array}$ & $\begin{array}{c}\text { Per- } \\
\text { centage } \\
\text { sold } \\
\text { green }\end{array}$ & Crop and pool & $\begin{array}{c}\mathrm{Re}- \\
\text { ceipts }\end{array}$ & $\begin{array}{c}\text { Sales } \\
\text { of green } \\
\text { tobacco }\end{array}$ & $\begin{array}{l}\text { Per- } \\
\text { centage } \\
\text { sold } \\
\text { green }\end{array}$ \\
\hline $\begin{array}{l}1922 \\
\text { Old belt } \\
\text { Eastern Carolina..... } \\
\text { South Carolina.... }\end{array}$ & $\begin{aligned} & 1,000 \\
& \text { pounds } 89,925 \\
& 23,228 \\
& 20,032\end{aligned}$ & \begin{tabular}{|c|}
1,000 \\
pounds \\
66,398 \\
12,703 \\
10,388
\end{tabular} & $\begin{array}{r}\text { Per cent } \\
73.84 \\
54.69 \\
51.86\end{array}$ & $\begin{array}{l}1924 \\
\text { Old belt } \\
\text { Eastern Carolina. } \\
\text { South Carolina...- }\end{array}$ & $\begin{array}{c}1,000 \\
\text { pounds } \\
58,261 \\
9,446 \\
13,791\end{array}$ & $\left|\begin{array}{c}1,000 \\
\text { pounds } \\
12,721 \\
447 \\
2,987\end{array}\right|$ & $\begin{array}{r}\text { Per cent } \\
21.83 \\
4.73 \\
21.66\end{array}$ \\
\hline $\begin{array}{l}\text { All flue-cured } \\
\text { Sun-cured................ } \\
\text { Dark-fired.......... }\end{array}$ & $\begin{array}{r}133,185 \\
3,580 \\
26,825\end{array}$ & $\begin{array}{r}89,489 \\
2,031 \\
20,773 \\
\end{array}$ & $\begin{array}{l}67.19 \\
56.73 \\
77.44\end{array}$ & $\begin{array}{l}\text { All flue-cured.... } \\
\text { Sun-cured } \\
\text { Dark-fired.-......-.... }\end{array}$ & $\begin{array}{r}81,498 \\
2,117 \\
20,227\end{array}$ & $\begin{array}{r}16,155 \\
2,071 \\
2,232\end{array}$ & $\begin{array}{l}19.82 \\
97.83 \\
11.04\end{array}$ \\
\hline All pools & 163,590 & 112,293 & 68.64 & All pools... & 103,842 & 20,458 & 19.70 \\
\hline $\begin{array}{l}1923 \\
\text { Old belt } \\
\text { Eastern Carolina... } \\
\text { South Carolina... }\end{array}$ & $\begin{array}{l}91,491 \\
26,945 \\
34,933\end{array}$ & $\begin{array}{r}31,976 \\
6,663 \\
10,863\end{array}$ & $\begin{array}{l}34.95 \\
24.73 \\
31.46\end{array}$ & $\begin{array}{l}\qquad 1925 \\
\text { Old belt } \\
\text { Eastern Carolina... } \\
\text { South Carolina... }\end{array}$ & $\begin{array}{r}34,620 \\
6,965 \\
25,570\end{array}$ & $\begin{array}{r}4,031 \\
742 \\
1,484\end{array}$ & $\begin{array}{r}11.64 \\
10.65 \\
5.80\end{array}$ \\
\hline $\begin{array}{l}\text { All flue-cured.. } \\
\text { Sun-cured -.......... } \\
\text { Dark-fired............ }\end{array}$ & $\begin{array}{r}152,969 \\
3,020 \\
24,149\end{array}$ & $\begin{array}{r}49,502 \\
2,614 \\
12,551\end{array}$ & $\begin{array}{l}32.36 \\
86.56 \\
51.97\end{array}$ & $\begin{array}{l}\text { All flue-cured. } \\
\text { Sun-cured } \\
\text { Dark-fired............... }\end{array}$ & $\begin{array}{r}67,155 \\
1,973 \\
14,506\end{array}$ & $\begin{array}{l}6,257 \\
1,863 \\
4,696\end{array}$ & $\begin{array}{r}9.32 \\
94.42 \\
32.37\end{array}$ \\
\hline All pools. & 180,138 & 64,667 & 35.90 & All pools. & 83,634 & 12,816 & 15.32 \\
\hline
\end{tabular}

After the association's tobacco had been redried at some designated redrying plant, it was consigned to various storage warehouses, licensed under the Federal warehouse act of 1916. A complete record of the grade of tobacco in every hogshead was kept by the leaf department. Efforts were made to sell this tobacco as rapidly as possible, at prices previously determined by the sales committee. The method used in determining the prices for the different grades of redried tobacco was to add to the reserve price of similar grades of green tobacco, the cost of redrying and the cost of storing. Allowance had also to be made for the shrinkage in weight which took place during the redrying process. This shrinkage varies somewhat depending upon the percentage of moisture in the green tobacco before it is redried, but it is usually regarded as averaging 10 per cent of the weight of the tobacco in the green state.

An attempt was made to sell the redried tobacco at prices varying around the reserve prices. As time went on, however, it was found 
that it was not possible to obtain these reserve prices for all grades nor was it possible to increase such price from time to time to include accumulated carrying charges. The association was forced to sell a great deal of tobacco at considerably less than the reserve prices. It was also found that there was little or no demand for certain grades of tobacco (usually the smoking grades) and that the prices placed by the association on such grades were much too high.

In many instances the association failed to get as high a price for redried tobacco as it did for green tobacco of like grade, even before the redrying and carrying charges were deducted. ${ }^{45}$ The difference between the results of the sales of green and redried tobacco becomes even more apparent when such charges are deducted. In the majority of instances the net price per grade of redried tobacco (that is the redried prices less redrying and carrying charges) is below, sometimes considerably below, the prices obtained for a comparable grade of green tobacco. Much of the tobacco that passed into the hands of the receivers was sold for lower prices than were obtained for similar grades by the association, and thus reduced still further the average net prices for redried tobacco.

If the results of sales of green and redried tobacco for the 1922 and 1923 crops had been analyzed in this manner by the association it would have been apparent that the redrying of tobacco was not a profitable undertaking and that it was advisable to sell as much tobacco in the green state as possible. There is no means of ascertaining whether this policy would have affected the price of green tobacco; the prices of green tobacco might have been reduced but probably not any considerable extent. The Federal Trade Commission maintained that many leaf dealers were prepared to purchase green tobacco from the association during the years 1924 and 1925 at the prices demanded by the association $(12, p .76-7 / 7)$. Under these circumstances the association's policy to discontinue sales of green tobacco to leaf dealers in 1924 was most unfortunate.

The accusation has often been made that the policy of refraining from selling green tobacco of the 1924 crop to exporters and leaf dealers was not to promote the interest of the assocation, but to enable some of its officers to redry a large quantity and to profit thereby. There appears to be a general opinion among the association members that this was true. The Federal Trade Commission stated $(12, p .9)$ :

The policy of excluding exporters and dealers as purchasers of green tobacco resulting in larger shipments to redrying plants manifestly benefited a number of the cooperative's officials, including the majority of its sales staff and several directors through their financial interests in redrying plants.

Whatever the facts may be, it is regrettable that the interest in redrying plants of certain influential officers of the association may have caused them to be somewhat less diligent in marketing the tobacco in the green state.

It might have been advisable, if it had been possible, to sell some of the lower grades of green tobacco at auction. This would have tended to reduce the prices received by nonmembers for such grades,

${ }^{45}$ In Tables 56 to 60 in the appendix is presented a list of the prices by grade obtained by the association for green and redried tobacco in the eastern Carolina and South Carolina pools for the 1923 and 1924 crops, and the old-belt pool for the 1924 crop. 
and the association would have been spared the loss it subsequently incurred by redrying and storing such large quantities of low-grade tobacco. The association could possibly have done this by operating POUNDS

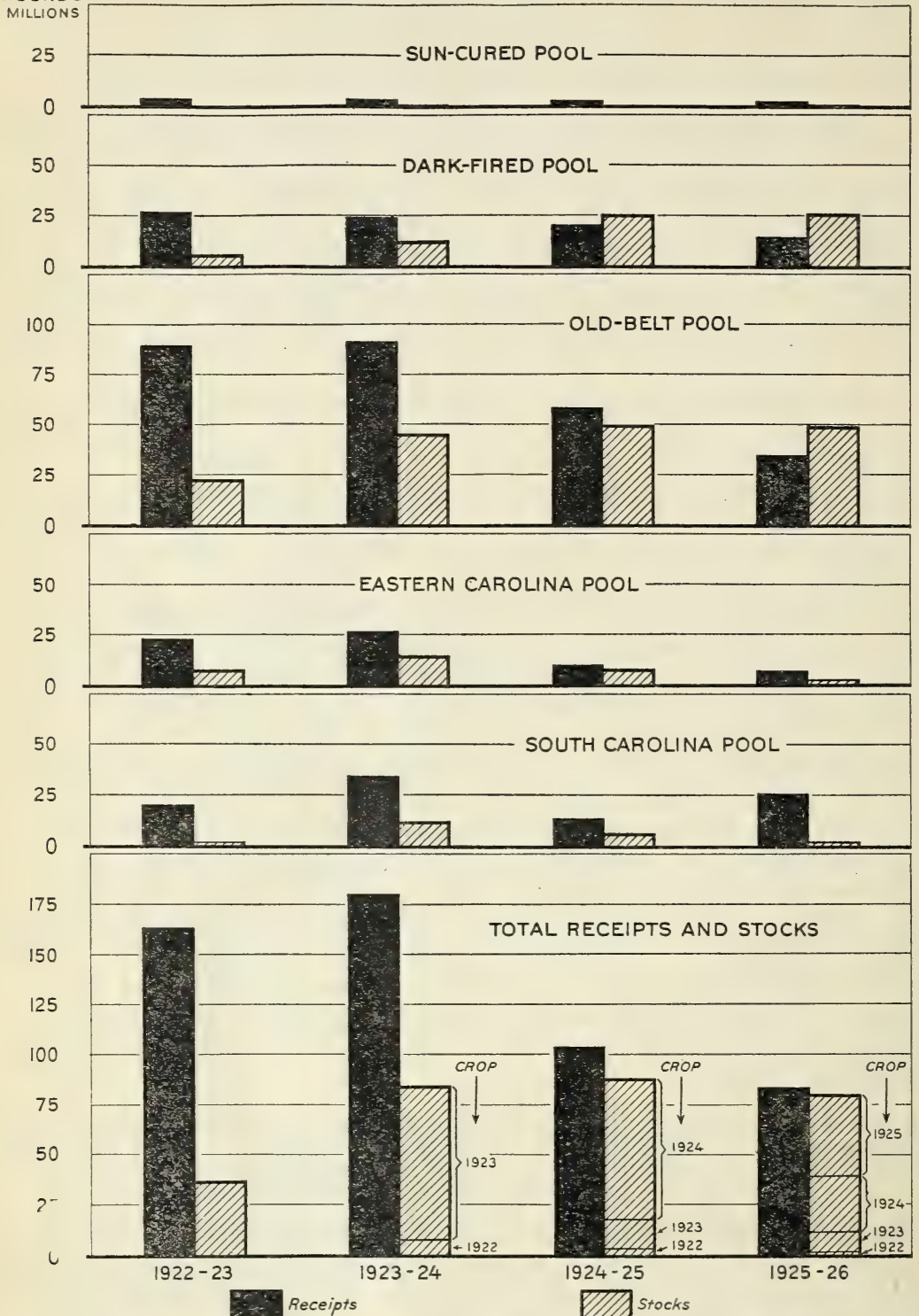

FIGURE 17.-RECEIPTS OF TOBACCO AND STOCKS ON HAND AT END OF FINANCIAL YEAR, BY POOLS, 1922-23 TO I925-26

Despite the decrease in total receipts the stocks of tobacco on hand tended to increase. This was true especially of the dark-fired and old-belt pools.

several of its warehouses under the auction-floor system, provided the tobacco buyers and leaf dealers would have supported such $a$ procedure. 
The large tobacco companies had obtained adequate supplies of most grades of tobacco on the open auction warehouse floors at about the same (or somewhat higher) prices that were demanded by the association. These companies were then not willing to take such grades of tobacco from the association unless the price was considerably reduced. This placed the association in an embarrassing position, for when the prices were first set on these grades of tobacco they were not out of line with the prices being paid to nonmembers for similar grades of tobacco. If the association had been forced greatly to reduce its prices for such tobacco the average price would have been seriously lowered. ${ }^{46}$ This would have aggravated the discontent already existing among members. Rather than make considerable reductions, the tobacco was kept in the hope that conditions would improve. As a matter of fact, instead of improving, conditions gradually became worse. The volume of such tobacco in storage gradually increased and added to the problems of the association.

Figure 17 indicates that although receipts of tobacco from members fell off considerably after 1923, the stocks of leaf tobacco at the end of each succeeding crop year tended to increase. The stocks at the end of the 1925 crop year were almost $8,000,000$ pounds less than they were at the end of the previous crop year; this was due largely to the fact that deliveries had decreased by over $20,000,000$ pounds. Increase in stocks from 1923 to 1926 was due to a relative decrease in the annual sales. Table 55 in the appendix and Figure 18 show that not only did the sales fall off every year after 1923, but the percentage of sales to receipts plus stocks fell off every year after 1922. This was probably due to an accumulation of these grades of tobacco which were increasingly difficult to sell. It appears to bear out the contention of the sales committee that many members during the last few years delivered only their lower grades of tobacco to the association and sold their better grades on the open auction warehouse floors. It was almost impossible to dispose of much of the dark-fired tobacco and many of the lower grades of flue-cured tobacco at the reserve prices the association had placed on such tobacco.

It is possible that the handling of dark-fired tobacco increased the difficulties and the expense of operating the association. The demand for dark-fired tobacco had been decreasing steadily for years and an increasing proportion of the stocks of tobacco held by the association at the end of each year consisted of this type. This undoubtedly increased the expense of selling, as the sales staff of the dark-leaf department had to make greater efforts to dispose of this low-value tobacco. It also increased the carrying expenses and the expenses of handling the flue-cured pools as the overhead expenses were prorated partly on a value basis. It now appears that it would have been better to organize separate sales pools to handle the different types of tobacco instead of burdening the more valuable types of tobacco with part of the expense of handling types for which there was a relatively small demand.

Table 40 shows the relative difficulty of selling the tobacco of the different pools. The dark-fired tobacco sold least well, 30.28 per cent

46 Farmers are more interested in the average price they obtain for their tobacco than in the prices they obtain for any particular grade.

$76534-29-7$ 
of the total receipts for the four years being on hand on June 19, 1926. Comprising only 16.13 per cent of the receipts of all tobacco, the inventory showed that dark-fired tobacco made up 33.68 per cent

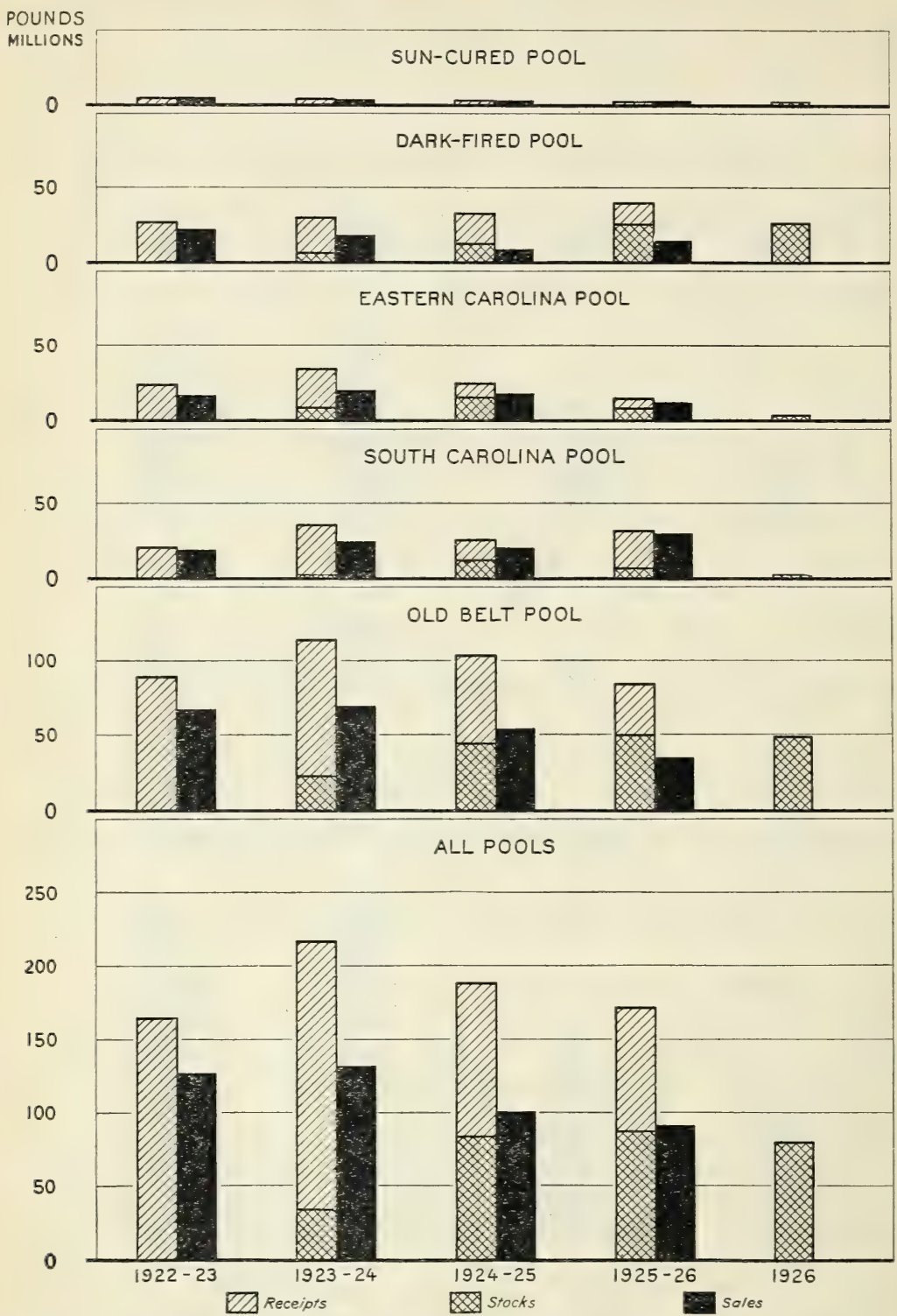

FIGURE 18.-RECÉIPTS, SALES, AND STOCKS ON HAND AT END OF FINANCIAL YEAR (GREEN BASIS) BY POOLS, I922-23 TO JUNE, 1926

Not only did the sales decrease every year after 1923 , but the percentage of sales to receipts plus stocks decreased appreciably after 1922 .

of the total on hand. The old-belt type of flue-cured was next slowest to move; 17.39 per cent of the receipts of this pool was on hand on the above date. Old-belt tobacco made up 51.64 per cent of 
the total receipts of association tobacco, but was 61.88 per cent of the unsold tobacco on hand on June 19, 1926. Sun-cured, South Carolina, and eastern Carolina pool tobacco sold best in the order named, the percentage of stocks on hand to receipts being $0.98,1.33$ and 3.11 per cent respectively.

TABLE 40.-Stocks of tobacco on hand (green basis) June 19, 1926, compared with total receipts for the four years, 1922-1925

\begin{tabular}{|c|c|c|c|c|c|}
\hline Pool & \multicolumn{2}{|c|}{ Total receipts, 4 crops } & \multicolumn{2}{|c|}{$\begin{array}{c}\text { Stocks on hand, June } \\
19,1926^{1}\end{array}$} & $\begin{array}{l}\text { Stocks, } \\
\text { June 19, } \\
1926, \text { as } \\
\text { a per- } \\
\text { centage of } \\
\text { receipts }\end{array}$ \\
\hline $\begin{array}{l}\text { Sun-cured } \\
\text { Dark-fired.-. } \\
\text { Old belt } \\
\text { Eastern Carolina... } \\
\text { South Carolina.... }\end{array}$ & $\begin{array}{c}\text { Pounds } \\
10,689,485 \\
85,706,372 \\
274,296,551 \\
66,581,931 \\
93,925,657\end{array}$ & $\begin{array}{r}\text { Per cent } \\
2.01 \\
16.13 \\
51.64 \\
12.54 \\
17.68\end{array}$ & $\begin{array}{r}\text { Pounds } \\
105,165 \\
25,956,007 \\
47,692,348 \\
2,070,548 \\
1,253,637\end{array}$ & $\begin{array}{r}\text { Per cent } \\
0.14 \\
33.68 \\
61.88 \\
2.67 \\
1.63\end{array}$ & $\begin{array}{r}0.98 \\
30.28 \\
17.39 \\
3.11 \\
1.33\end{array}$ \\
\hline Total.. & $531,202,996$ & 100.00 & $77,077,705$ & 100.00 & 14. 51 \\
\hline
\end{tabular}

1 The tobacco on hand at the date of the receirership, June 19,1926 (appendix Table 14), was reduced to the green basis by adding 10 per cent, to the redried quantities.

The board of directors has frequently been accused of holding the prices too high. This accusation, although practically true, is somewhat unfair. The fact that stocks continue to accumulate in the hands of the association might indicate that the prices were too high, but the policy of the association was to maintain the prices originally placed on the tobacco in accord with the bankers' valuation. A definite change of policy was not later entertained by the board of directors nor generally demanded by the membership. The prices originally placed upon the different grades of tobacco were not out of line with the prices prevailing on the auction floors.

In fact it would appear that the prices decided upon by the association determined prices paid at the auction-floor warehouses. These prices were possibly higher than the tobacco buyers would have paid with no cooperative association operating. It is more than probable that the companies were prepared to make sacrifices in order to embarrass the association and so hasten its collapse. This practice has frequently been adopted in other fields of business and there is no reason why the large tobacco companies would not have followed it. In all fairness to the sales committee, it must be stated that they fully realized the danger of placing too high a reserve price on the green tobacco. In October, 1922, the general manager of the bright-leaf department presented a letter to the executive committee which pointed out the danger that would result from placing an abnormal price on tobacco and redrying it with a view to carrying it over into another crop year. It was shown that the association would be placed in a very uncomfortable position if the large tobacco companies succeeded in obtaining all their requirements on the open warehouse floors. He then recommended that as much tobacco as possible should be sold in the green state.

In the absence of reliable information about such purchases it is difficult to ascertain what factors influenced the large tobacco com- 
panies in fixing the prices they were prepared to pay. It is thus impossible to say whether in setting the prices for the tobacco which they purchased on the open-auction warehouse floors during the time the association was in operation, they were influenced by the total supply arailable, including stocks in association storage warehouses, or merely br the supply immediately arailable on the auction floors. It would seem reasonable to suppose that they were guided mainly by the total risible supply and that they were prepared to pay somewhat higher prices for the stock purchased on the open-auction warehouse floors, with the idea that erentually the tobacco held by the association would be offered to them at prices low enough to offset the higher prices paid at the auction markets.

It has frequently been asserted that the fact that the association was in existence helped to keep up tobacco prices during the four vears 1922-1926 and that the tobacco growers as a whole were benefited. This was possibly the case, but the prices were largely due to the fact that only part of the crops produced in those years was sold. Much of the tobacco in storage on June 19, 1926, when the association affairs passed into receirership, has been sold at prices lower than the banker's raluations. If the arerage price is taken for all the tobacco produced in the area in those four years, it is doubtful whether the existence of the association did substantially enhance the total farm value of tobacco.

The refusal of the Imperial Tobacco Co. and the American Tobacco Co. to trade with the association added to the difficulties (12). The effect of the attitude of these companies and their leaf-buying forces was to delay or hinder parments to the members and to cause many to sell on the outside as a direct result. The refusal of these companies to purchase from the association undoubtedly lessened the competition for such tobacco. The position was not improred by the board's decision in 1924 to discontinue sales of green tobacco to leaf dealers. This practically left only two manufacturing companies to which the association could sell green tobacco. The Export Leaf Co. did not purchase tobacco in the green state from the association. The attempts to establish direct contact with European burers proved unsuccessful. Most foreign companies that did not hare their omn burers on the markets had for rears bought their tobacco through some established American leaf dealers, and apparently were unwilling to break their connections.

Table 41 shows the total quantities of tobacco, green and redried, of the 1922, 1923, and 1924 crops purchased from the association by the larger tobacco companies, and the percentages of the total sales taken by each company. Liggett \& Mrers Tobacco Co. was the largest buyer, taking as high as 41.8 per cent of the sales; this company with R. J. Reynolds Tobacco Co. took orer half of the sales as giren in this table. In absolute quantities the rolume taken by these two companies increased for the 1923 crop but decreased to about onefourth for the 1924 crop up to September 1, 1925.

The sales of tobacco to "all others" decreased from 69,092,008 pounds in 1922 to $7,512.615$ pounds in 1924 (to February 28, 1925). This decrease was no doubt due chiefly to the association policy of not selling tobacco in the green state to exporters and dealers. This policy was enacted to prevent the resale of association tobacco and 
not to exclude these two groups of customers; but in effect it prevented sales, as these exporters and leaf dealers are accustomed and equipped to buy tobacco in the green state.

TABLE 41.-Sales of tobacco of the 1922-1924 crops to the larger tobacco companies $^{1}$

\begin{tabular}{|c|c|c|c|c|c|c|}
\hline \multirow[b]{2}{*}{ 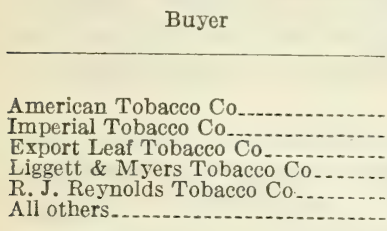 } & \multicolumn{2}{|l|}{1922} & \multicolumn{2}{|l|}{1923} & \multicolumn{2}{|l|}{1924} \\
\hline & $\begin{array}{l}\text { Pounds } \\
5,132,554 \\
458,507 \\
9,420,091 \\
39,162,482 \\
24,118,925 \\
69,092,008\end{array}$ & \begin{tabular}{|c|} 
Per cent \\
3.48 \\
.31 \\
6.39 \\
26.57 \\
16.36 \\
46.89
\end{tabular} & $\begin{array}{r}\text { Pounds } \\
27,446 \\
21,187,117 \\
41,588,998 \\
43,031,222 \\
49,073,742\end{array}$ & \begin{tabular}{r|} 
Per cent \\
0.02 \\
13.68 \\
26.85 \\
27.78 \\
31.67
\end{tabular} & $\begin{array}{r}\text { Pounds } \\
54,096 \\
417,192 \\
212,957,879 \\
210,104,123 \\
87,512,615\end{array}$ & $\begin{array}{r}\text { Per cent } \\
0.17 \\
1.34 \\
41.74 \\
32.55 \\
24.20\end{array}$ \\
\hline Total & $147,384,557$ & 100.00 & $154,908,525$ & 100.00 & $31,045,905$ & 100.00 \\
\hline
\end{tabular}

${ }^{1}$ As some of the association sales data are missing from the association files it was not possible to bring the sales data up to date or show them in more detail. For this reason the data given in the above-named document are used.

2 To Sept. 1, 1925 .

3 To Feb. 28, 1925.

Federal Trade Commission Report, Senate Document 34 (12, p. 40).

Two large tobacco manufacturing companies, Liggett \& Myers and R. J. Reynolds \& Co., which at all times bought tobacco from the association, purchased less green tobacco during the last three years. In 1922 these two companies purchased in the green state 30.7 per cent of the total quantity of tobacco received by the association. In 1923 and 1924 they purchased 20.1 and 16.4 per cent, respectively. In 1925 the proportion was somewhat higher owing to the influence on total sales of sun-cured tobacco sold in the green state. Both these companies continued to purchase redried tobacco heavily. The decrease in the sales of green tobacco to these companies may have been due to one or both of two reasons: (1) Several of the officers and directors were financially interested in redrying association tobacco and for this reason the sales staff may not have been as diligent as they should have been in negotiating green sales; and (2) one or both of these companies may have found that it was to their advantage to purchase tobacco in the redried rather than in the green state.

Furthermore, the buyers of association tobacco did not always take immediate delivery of the stock they purchased. They sometimes stored it in association warehouses for several months. No charge for such storage was made by the association, but the association continued to pay storage, interest, and other carrying charges. It would appear that, owing to its unenviable position of dependence on the good will of the tobacco companies, the association was forced to render many kinds of services in order to promote sales.

In nearly all instances the prices obtained by the association for redried tobacco were lower than the price obtained for green tobacco, after allowance for shrinkage and redrying charges had been made. The prices of redried tobacco could not be raised in proportion as carrying charges accumulated. Obviously in such circumstances it was to the advantage of these companies to allow the association to store the tobacco until it was required by them. All 
these companies may have had some unoccupied storage space, but they saved the interest and insurance during the period the association stored the purchases. These companies could probably have had the green tobacco redried more cheaply than the association did, ${ }^{47}$ but this practice would have been more than offset by the accumulated carrying charges, in instances in which the tobacco was stored by the association for a year or more, and by the fact that the accumulation of stocks forced the association to sell its redried tobacco at prices somewhat below the original reserve prices placed on redried tobacco.

It would appear that the purchasers of association tobacco obtained another advantage. The stocks taken over by the receivers have been found to be greatly overgraded. Some of the tobacco specialists of the Bureau of Agricultural Economics, who kept in constant touch with the grading of the association, state that on the whole it was well done and that all of the overgraded tobacco could not possibly have been the result of faulty grading only. Within every grade of tobacco there is a certain range of quality. Some of the tobacco in the upper range might go into a higher grade and some in the lower range might go into a lower grade. It would appear that several of the companies that bought from the association accepted only the best tobacco in each grade; the remainder then fell into the upper portion of the next lower grade. To what extent this so-called "creaming" practice took place would be impossible to state but, on examination, the association's ledger accounts of some of these tobacco companies indicate that rejections were by no means an infrequent occurrence.

The former general manager of the association maintains that it was not possible for customers to reject tobacco in this way. When tobacco was purchased from the association, from 10 to 20 per cent of the hogsheads were opened by the examiners of the purchasing company before the tobacco left the association's storage warehouses. An inspector of the association was present at the customer's warehouse when the hogsheads were delivered, and this inspector, together with an examiner of the buyer, examined the tobacco. In case the tobacco did not come up to specifications, the hogsheads were returned to the association or a lower price was arranged by mutual consent.

It is difficult to account for the large quantity of overgraded tobacco taken over by the receivers, unless this "creaming" took place or unless there was substitution by the redriers.

\section{MEMBER AND NONMEMBER PRICES}

It is maintained by some farm leaders in the tri-State area that the operations of the tobacco cooperative association resulted not only in better prices to the members than they would have received if they had been unorganized but in better prices to nonmembers as well. Table 42 and Figure 19 show the index numbers of the purchasing power (prices deflated by the bureau of Labor Statistics Index Numbers) of flue-cured, dark-fired, sun-cured, and all United

${ }^{47} \mathrm{It}$ is probable that tobacco could have been redried at about $\$ 1$ or less per 100 pounds, whereas the association paid $\$ 1.75$ or more. 
States tobacco (with the average pre-war crop years 1910-11 to $1914-15$ as a base of 100 ) for the war years, for the period of depression immediately following, for the 4-year period of the association's operations, and for the two crops following the failure of the association. As the price data from the Yearbooks of the United States Department of Agriculture do not reflect the quality of the crop, the prices given are averages by types for all grades.

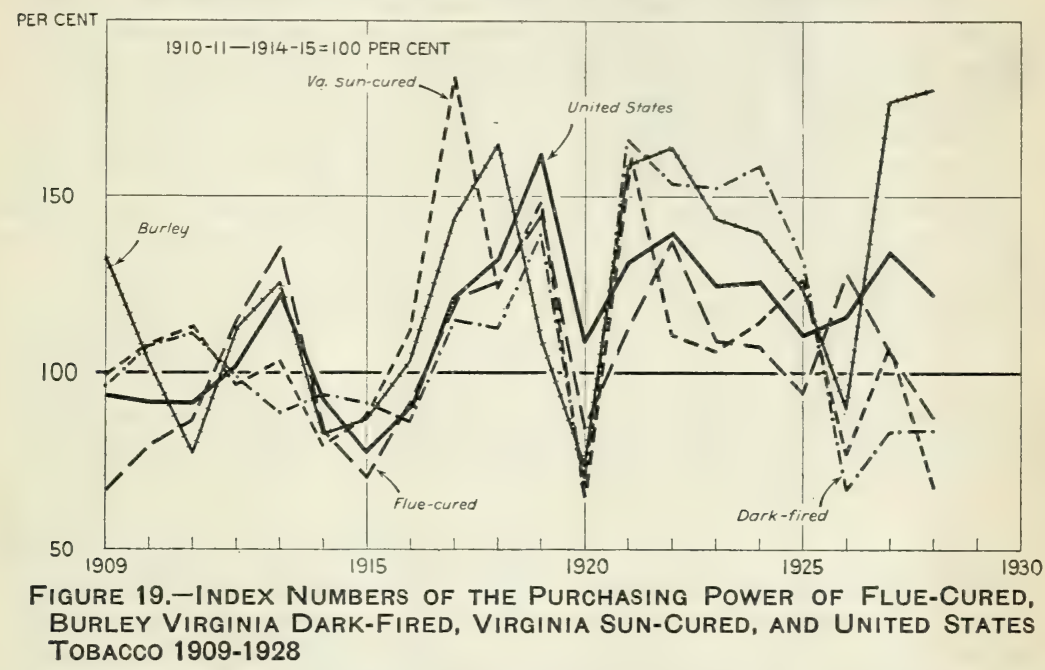

The purchasing power of all types of tobacco fell below the pre-war level in 1920 . During the four years of the operation of the association, 1922-1925, the prices were well above this level, but since the receivership Virginia dark-fired and sun-cured types have averaged considerably below. Flue-cured values show a downward trend since 1922.

TABLE 42.-Index numbers of the purchasing power of tobacco, 1910-11 to $1928-29^{1}$

\begin{tabular}{|c|c|c|c|c|c|c|}
\hline Type of tobacco & $\begin{array}{c}1910-11 \text { to } \\
1914-15\end{array}$ & $\begin{array}{c}1917-18 \text { to } \\
1919-20\end{array}$ & $1920-21$ & $1921-22$ & $\begin{array}{c}1922-23 \text { to } \\
1925-26\end{array}$ & $\begin{array}{l}1926-27 \text { to } \\
1928-29=\end{array}$ \\
\hline $\begin{array}{l}\text { Flue-cured } \\
\text { Virginia dark-fired... } \\
\text { Virginia sun-cured... }\end{array}$ & $\begin{array}{l}100 \\
100 \\
100\end{array}$ & $\begin{array}{l}130.2 \\
122.0 \\
152.0\end{array}$ & $\begin{array}{l}84.6 \\
68.3 \\
65.0\end{array}$ & $\begin{array}{l}112.3 \\
166.2 \\
160.5\end{array}$ & $\begin{array}{l}111.7 \\
148.9 \\
114.0\end{array}$ & $\begin{array}{r}107.0 \\
78.2 \\
83.7\end{array}$ \\
\hline Average 3 types... & 100 & 144.2 & 59.3 & 142.4 & 126.7 & 92.7 \\
\hline All United States tobacco.. & 100 & 138.3 & 108. 2 & 13i. 2 & 125.0 & 123.9 \\
\hline
\end{tabular}

1 Average price per pound, as reported by the Division of Crop and Livestock Estimates, United States Bureau of Agricultural Economics, divided by the All-Commodity Index Number, Bureau of Labor Statistics, with the average for the crop years, 1910-11 to 1914-15 as 100.

${ }^{2}$ Preliminary.

During 1917-18, 1918-19, and 1919-20 the average purchasing power of all tobacco increased to 138.3 per cent of the pre-war level. In 1920-21 it dropped to 108.2 per cent of the pre-war figure for all United States tobacco; and to as low as 65 per cent for sun-cured tobacco, 68.3 per cent for dark-fired, and 84.6 per cent for flue-cured tobacco. The next year, 1921-22, the purchasing power for all United States tobacco increased to 131.2 per cent of the base period, and an average of 142.4 per cent for the above three classes. 
During the four years, 1922-1925, when the association was in operation, the purchasing power of all United States tobacco averaged 25 per cent above that of the 1910-1914 period. For the three classes handled by the association the increase was 26.7 per cent. The purchasing power of dark-fired tobacco increased more than those of either flue-cured or sun-cured tobacco.

During the three years following immediately after the association ceased to operate, 1926,1927 , and 1928, the purchasing power of all types of United States tobacco showed a slight decrease over that existing during the years of its operation. As compared with the base period figures, flue-cured tobacco showed a slight upward trend in purchasing power with an increase of 7 per cent above the prewar average. Both dark-fired and sun-cured tobaccos showed a sudden decline at the time of the receivership of the association. From an average of 148.9 for the association period, the average purchasing power in the period 1926-27 to 1928-29 dropped to 78.2 per cent of the 1910-11 to 1914-15 average for dark-fired tobacco. For suncured tobacco there was a decline from 114 per cent to 83.7 per cent.

It would seem, therefore, that if the association were responsible for any increase in tobacco prices, it was for the prices of the dark-fired and sun-cured types. The flue-cured type has shown a general upward trend in prices irrespective of the existence or nonexistence of the association. However, other factors than the existence of the association may have entered to affect the prices which obtained for the different types of tobacco. These factors may have worked in the same direction as the presence of the association did in affecting tobacco prices, or they may have influenced prices in the opposite direction in spite of the presence of the association.

The task of ascertaining whether the association succeeded in obtaining better prices for its members' tobacco than were obtained on the auction floors was rendered exceedingly difficult. (1) Only 7 of the 20 pools that operated during the four years had been closed by May 31, 1926, the end of the last financial year just before receivers were appointed for the association. This caused difficulties of accounting in prorating the expenses incurred between the tobacco that was sold and the tobacco shown in the inventories of the receivers. (2) The comparison of the average prices obtained for tobacco sold under the cooperative and the auction-floor systems of marketing is unreliable because of the impossibility of determining whether the quality of tobacco sold under these two methods was comparable. The officers in the leaf department of the association claimed, and there is every reason to believe that their claim was founded on facts, that in a large number of instances members delivered their poorer grades of tobacco to the association and sold their better grades at auction. In these circumstances the mere fact that the association obtained lower average prices than were obtained under the auctionfloor system of marketing would not necessarily mean that the association's results were unsatisfactory. On the contrary, a comparison of prices of association grade with auction grade might have shown favorable results for the association.

Several attempts were made in this study to arrive at a satisfactory comparison of prices by grades of tobacco and to ascertain whether the tobacco delivered to the association was on the whole of a poorer quality than was the tobacco sold under the auction-floor system. 
An attempt was made to obtain records of sales for the years 1922 to 1926 from various independent warehousemen who had operated auction-floor warehouses in some of the markets in which the association had receiving points. It was hoped that, if representative samples could be extracted from the list of sales made at these warehouses, some idea of the quality of the tobacco might be obtained. Then it would be possible to compare the quality of tobacco sold at these auction-floor warehouses with the quality of the tobacco delivered to the association in the same markets. The records of sales each year were tabulated but the results were unsatisfactory and it was impossible to make a comparison of the grades of tobacco purchased from the two sources by the tobacco companies.

The association records of deliveries, by grades, of flue-cured tobacco were analyzed with a view to ascertaining whether there was any tendency for the general average of quality to be lower during the last three years. Lists were prepared by the association showing the number of pounds of each grade of tobacco delivered annually in each pool. Tobacco is usually classed in several broad divisions known as "family blocks," which indicate roughly the use to which the tobacco falling under these blocks is put. For instance the association divided its flue-cured tobacco into seven family blocks as follows :

Family block A-wrappers.

Family block B-export cutting leaf.

Family block C-fillers.

Family block D-cutters.

Family block E-smoking lugs.

Family blocks F-primings (lower grades of tobacco).

Family blocks $\mathrm{H}$-domestic cutting leaf.

Each of these family blocks is divided into several grades, depending chiefly upon color and quality.

The method used was to divide arbitrarily the tobacco delivered in each family block into two sections. Similar divisions were made in each pool each year. For instance, the family block $\mathrm{A}$ for the South Carolina pools was so divided that in each year the number of pounds delivered in all grades above A 20 fell into the upper section, and all tobacco delivered below that grade fell into the lower section of the family block. Similar divisions were made for the other family blocks. The quantity of tobacco in the upper and lower sections was then divided by the total quantity of tobacco in the pool and multiplied by 100 to put the result on a percentage basis. The percentages for the upper and lower sections of each family block were then added. 'The results so obtained are indicated in Table 43.

In the old-belt pools the percentage in the upper sections decreased each year. This would seem to indicate either that members delivered a larger percentage of the poorer grades during the last three years or that the crops were poorer. In the South Carolina pool little definite change was found except that during the second year the total percentage of the upper section increased. For the eastern Carolina pools the percentage in the upper sections increased. The number of members who delivered tobacco in the eastern Carolina pool declined very rapidly from year to year. It is probable that the better farmers remained loyal to the association. If this is true, 
the quality of tobacco in those pools would tend to improve during the later years.

TABLE 43.-Distribution of the fue-cured tobacco received among the association grades

\begin{tabular}{|c|c|c|c|c|c|c|c|c|}
\hline \multirow{2}{*}{ Family block } & \multicolumn{2}{|c|}{1922 crop } & \multicolumn{2}{|c|}{1923 сrop } & \multicolumn{2}{|c|}{1924 crop } & \multicolumn{2}{|c|}{1925 crop } \\
\hline & $\begin{array}{r}\text { Upper } \\
\text { section }\end{array}$ & $\begin{array}{l}\text { Lower } \\
\text { section }\end{array}$ & $\begin{array}{l}\text { Upper } \\
\text { section }\end{array}$ & $\begin{array}{l}\text { Lower } \\
\text { section }\end{array}$ & $\begin{array}{l}\text { Upper } \\
\text { section }\end{array}$ & $\begin{array}{l}\text { Lower } \\
\text { section }\end{array}$ & $\begin{array}{l}\text { Upper } \\
\text { section }\end{array}$ & $\begin{array}{l}\text { Lower } \\
\text { section }\end{array}$ \\
\hline 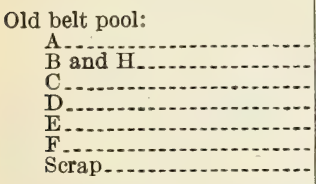 & $\begin{array}{r}\text { Per cent } \\
1.40 \\
18.90 \\
2.85 \\
5.26 \\
16.28 \\
1.83 \\
0\end{array}$ & $\begin{array}{r}\text { Per cent } \\
3.97 \\
15.59 \\
4.80 \\
18.59 \\
8.73 \\
1.76 \\
.04\end{array}$ & $\begin{array}{r}\text { Per cent } \\
0.82 \\
22.85 \\
.86 \\
2.90 \\
15.21 \\
2.77 \\
0\end{array}$ & $\begin{array}{r}\text { Per cent } \\
2.32 \\
23.94 \\
1.09 \\
14.54 \\
9.51 \\
2.70 \\
.49\end{array}$ & $\begin{array}{r}\text { Per cent } \\
0.90 \\
23.64 \\
1.13 \\
5.14 \\
11.44 \\
2.37 \\
0\end{array}$ & $\begin{array}{r}\text { Per cent } \\
1.89 \\
28.22 \\
1.55 \\
12.90 \\
7.79 \\
1.67 \\
1.36\end{array}$ & $\begin{array}{r}\text { Per cent } \\
0.13 \\
13.26 \\
.22 \\
1.32 \\
9.38 \\
1.05 \\
0\end{array}$ & $\begin{array}{r}\text { Per cent } \\
0.45 \\
48.65 \\
.67 \\
6.84 \\
13.68 \\
2.73 \\
1.62\end{array}$ \\
\hline Total .. & 46.52 & 53.48 & 45.41 & 54.59 & 44.62 & 55.38 & 25.36 & 74. 64 \\
\hline $\begin{array}{l}\text { Eastern Carolina pool: } \\
\text { A } 1 \text { and Ḧ} \\
\text { C } \\
\text { D } \\
\text { E F } \\
\text { Scrap }\end{array}$ & $\begin{array}{r}.08 \\
15.89 \\
0 \\
8.80 \\
11.42 \\
5.11 \\
0\end{array}$ & $\begin{array}{r}.23 \\
25.60 \\
0 \\
14.69 \\
7.48 \\
5.98 \\
4.72\end{array}$ & $\begin{array}{r}.07 \\
21.27 \\
0 \\
6.12 \\
9.49 \\
7.07 \\
0\end{array}$ & $\begin{array}{r}.14 \\
30.75 \\
0 \\
14.76 \\
3.39 \\
5.49 \\
1.45\end{array}$ & $\begin{array}{r}.11 \\
21.88 \\
0 \\
11.52 \\
8.57 \\
6.22 \\
0\end{array}$ & $\begin{array}{r}24.14 \\
0 \\
16.37 \\
2.80 \\
4.19 \\
3.73\end{array}$ & $\begin{array}{r}22.18 \\
0 \\
11.54 \\
6.72 \\
8.30 \\
0\end{array}$ & $\begin{array}{r}.26 \\
23.02 \\
0 \\
15.20 \\
2.09 \\
8.36 \\
2.05\end{array}$ \\
\hline Total. & 41. 30 & 58. 70 & 44.02 & 55.98 & 48.30 & 51.70 & 49.02 & 50.98 \\
\hline 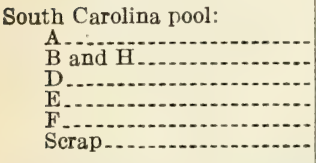 & $\begin{array}{r}.08 \\
15.27 \\
5.27 \\
11.83 \\
4.92 \\
0\end{array}$ & $\begin{array}{r}32.26 \\
11.91 \\
7.60 \\
3.65 \\
6.96\end{array}$ & $\begin{array}{r}.01 \\
27.74 \\
5.04 \\
7.94 \\
4.33 \\
0\end{array}$ & $\begin{array}{r}.27 \\
33.60 \\
13.50 \\
2.15 \\
2.17 \\
3.25\end{array}$ & $\begin{array}{r}.01 \\
18.90 \\
3.70 \\
10.26 \\
5.73 \\
0\end{array}$ & $\begin{array}{r}.07 \\
32.73 \\
12.36 \\
5.45 \\
5.73 \\
5.06\end{array}$ & $\begin{array}{r}.01 \\
22.08 \\
2.74 \\
8.66 \\
3.70 \\
0\end{array}$ & $\begin{array}{r}.08 \\
37.41 \\
10.48 \\
4.52 \\
4.63 \\
5.69\end{array}$ \\
\hline Total.... & 37.37 & 62.63 & 45.06 & 54.94 & 38.60 & 61.40 & 37.19 & 62.81 \\
\hline
\end{tabular}

In Table 44 are presented the gross average prices per 100 pounds realized by the association on sales of green and redried tobacco. These figures were obtained by dividing the proceeds of the sales of green and redried tobacco by the number of pounds sold under each class. Higher average prices per 100 pounds were obtained on the redried tobacco in all of the 1922 pools, and in every pool of the 1923 crop except the old-belt and sun-dried pools. Higher average prices were obtained on redried tobacco only in the dark-fired pool of the 1924 crop and in the South Carolina pool of the 1925 crop. Redried tobacco should sell at a higher average price than green tobacco of equivalent quality because it has been partly processed. It is impossible to tell from the average prices for all grades whether res?ried tobacco was sold more advantageously than green tobacco. It was necessary to analyze the sales of green and redried tobacco on a grade basis. This information appears in Tables 56 to 60 (appendix), from which it will be seen that, in spite of the more valuable condition of redried tobacco, the association failed to obtain higher prices for many grades of redried tobacco. The reason for this has been explained. 
TABLE 44.-Average price per hundred pounds obtained by the Tobacco Growers' Cooperative Association prior to receivership

\begin{tabular}{|c|c|c|c|c|c|c|c|c|c|c|c|c|}
\hline \multirow[b]{2}{*}{ Pool } & \multicolumn{3}{|c|}{$1922 \mathrm{cron}$} & \multicolumn{3}{|c|}{1923 crop } & \multicolumn{3}{|c|}{1924 сrop } & \multicolumn{3}{|c|}{1925 crop } \\
\hline & 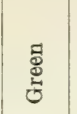 & 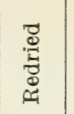 & 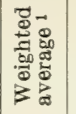 & 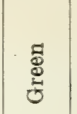 & 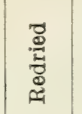 & 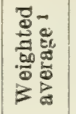 & 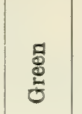 & 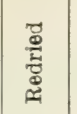 & 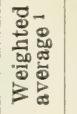 & 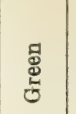 & 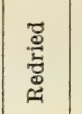 & 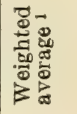 \\
\hline $\begin{array}{l}\text { Sun-cured.... } \\
\text { Dark-fired-... } \\
\text { Old belt } \\
\text { Eastern Carolina } \\
\text { South Carolina. }\end{array}$ & \begin{tabular}{|l|} 
Dolls. \\
10.96 \\
16.87 \\
24.31 \\
19.10 \\
15.06
\end{tabular} & $\begin{array}{c}\text { Dolls. } \\
14.11 \\
18.92 \\
31.82 \\
27.56 \\
23.74\end{array}$ & \begin{tabular}{|r|} 
Dolls. \\
12.33 \\
17.29 \\
26.25 \\
22.89 \\
19.24
\end{tabular} & $\begin{array}{l}\text { Dolls. } \\
12.97 \\
17.98 \\
21.07 \\
19.46 \\
19.46\end{array}$ & $\begin{array}{l}\text { Dolls. } \\
11.91 \\
20.31 \\
20.78 \\
23.25 \\
23.25\end{array}$ & $\begin{array}{l}\text { Dolls. } \\
12.83 \\
18.61 \\
20.88 \\
21.33 \\
22.06\end{array}$ & $\begin{array}{l}\text { Dolls. } \\
14.26 \\
15.32 \\
26.59 \\
32.51 \\
21.77\end{array}$ & $\begin{array}{r}\text { Dolls. } \\
3.01 \\
20.13 \\
23.71 \\
24.61 \\
20.11\end{array}$ & $\begin{array}{l}\text { Dolls. } \\
14.02 \\
19.02 \\
23.71 \\
22.01 \\
20.48\end{array}$ & \begin{tabular}{|c|} 
Dolls. \\
16.32 \\
16.86 \\
23.15 \\
26.98 \\
18.04
\end{tabular} & \begin{tabular}{|c|} 
Dolls. \\
10.78 \\
22.45 \\
21.60 \\
20.68
\end{tabular} & $\begin{array}{l}\text { nolls. } \\
16.32 \\
16.65 \\
22.90 \\
22.42 \\
20.52\end{array}$ \\
\hline
\end{tabular}

1 Based on the relative volumes of green and redried tobacco sold, green basis.

Independent warehouse operators in the three States are required by law to render monthly statements to their respective State departments of agriculture showing the number of pounds of tobacco sold each month and the average price for which such tobacco was sold. This information is then tabulated by areas, which are practically equivalent to the areas of the various association pools, and is pulblished annually in the Yearbook of the United States Department of Agriculture. Data regarding the gross average prices for tobacco sold in the different areas under the auction-floor system of marketing during the years 1922 to 1925 are shown in Table 45. For the purpose of comparison, the gross average sales prices obtained by the association are also shown with the difference in prices of the two systems.

In three of the four years the association succeeded in obtaining better prices for tobacco sold in the South Carolina pools than were obtained for sales under the auction-floor system of marketing. For tobacco in the eastern Carolina pools, the association's gross average prices were in each instance lower than the average prices under the auction-floor system. The same is true for the sun-cured tobacco sold under the two systems. The association's average prices for sales of tobacco in the old-belt pool, which pool was the most important on a basis of both quantity and quality, were below the auction-floor system averages for the first two years. During the last two years the association old-belt prices were above the auction-floor prices, but attention should be directed to the fact that in both of these pools the association still had large quantities of comparatively low-grade tobacco on hand on May 31, 1926. If this tobacco had been sold it would probably have greatly reduced the average prices obtained by the association during the years 1924 and 1925 . 
TABLE 45.-Prices of tobacco per 100 pounds received by the association and auction-floor prices

\begin{tabular}{|c|c|c|c|c|}
\hline Area and system & 1922 crop & 1923 crop & 1924 crop & 1925 crop \\
\hline $\begin{array}{l}\text { Sun-cured: } \\
\quad \text { Association sales....- } \\
\text { Auction-floor......-. }\end{array}$ & $\begin{array}{l}\text { Dollars } \\
12.33 \\
14.27\end{array}$ & $\begin{array}{l}\text { Dollars } \\
12.83 \\
13.22\end{array}$ & $\begin{array}{l}\text { Dollars } \\
14.02 \\
14.63\end{array}$ & $\begin{array}{l}\text { Dollars } \\
\quad 16.32 \\
\quad 16.39\end{array}$ \\
\hline Difference.... & -1.94 & -.39 & -.61 & -.07 \\
\hline $\begin{array}{l}\text { Dark-fired: } \\
\quad \text { Association sales........... } \\
\quad \text { Auction-floor }\end{array}$ & $\begin{array}{l}17.29 \\
19.77\end{array}$ & $\begin{array}{l}18.61 \\
18.09\end{array}$ & $\begin{array}{l}19.02 \\
19.43\end{array}$ & $\begin{array}{l}16.65 \\
16.24 \\
\end{array}$ \\
\hline Difference...... & -2.48 & .52 & -.41 & .41 \\
\hline $\begin{array}{l}\text { Old belt: } \\
\text { Association sales............ } \\
\text { Auction-floor }\end{array}$ & $\begin{array}{l}26.25 \\
30.25 \\
\end{array}$ & $\begin{array}{l}20.88 \\
21.49 \\
\end{array}$ & $\begin{array}{l}23.71 \\
21.69 \\
\end{array}$ & $\begin{array}{l}22.90 \\
17.33 \\
\end{array}$ \\
\hline Difference................ & -4.00 & -.61 & 2.02 & 5.57 \\
\hline $\begin{array}{l}\text { Eastern Carolina (new belt): } \\
\text { Association sales............. } \\
\text { Auction-floor............... }\end{array}$ & $\begin{array}{l}22.89 \\
29.70 \\
\end{array}$ & $\begin{array}{l}21.33 \\
24.00 \\
\end{array}$ & $\begin{array}{l}25.01 \\
25.50 \\
\end{array}$ & $\begin{array}{r}22.42 \\
25.40 \\
\end{array}$ \\
\hline Difference........ & -6.81 & -2.67 & -.49 & -2.98 \\
\hline $\begin{array}{l}\text { South Carolina: } \\
\text { Association sales........... } \\
\text { Auction-floor............. }\end{array}$ & $\begin{array}{l}\text { 19. } 24 \\
\text { 23. } 00\end{array}$ & $\begin{array}{l}22.06 \\
19.00\end{array}$ & $\begin{array}{l}20.48 \\
17.00\end{array}$ & $\begin{array}{l}20.52 \\
16.70\end{array}$ \\
\hline Difference...- & -3.76 & 3. 06 & 3.48 & 3.82 \\
\hline
\end{tabular}

Sun-cured and dark-fired auction-floor prices from Virginia Farm Statistics, 1926 (8, p. 82); auction-floor prices for other areas from U. S. Department of Agriculture Yearbook $1923(9, p .867)$ and similar tables in later yearbooks.

The importance of this comparison should not be exaggerated because it is impossible with the information available to ascertain to what extent the quality of tobacco sold under the two systems is comparable. There is good reason to believe that the tobacco sold by the association, especially during the last three years, was inferior in quality to that sold under the auction-floor system, but there is no means of ascertaining to what extent the qualities differed under the two systems. The gross average prices obtained by the association for the tobacco sold in the old-belt and dark-fired pools for 1925 are of little value for comparative purposes, as only a small proportion of the tobacco in these pools had been sold on May 31, 1926.

Table 46 gives, by pools and years, comparisons between the average auction-floor prices and the average bankers' valuation prices, and gives comparisons between the average auction-floor prices and the average prices remitted by the association to its members up to the time of the receivership.

In only three instances did the bankers' valuation prices exceed the auction-floor prices-in the South Carolina pool in 1924 and in the sun-cured and South Carolina pools in 1925. The differences for the four crops ranged from an average of 94 cents for the suncured pool to an average of $\$ 5.80$ in the eastern Carolina pool, and with an unweighted average auction-floor margin of $\$ 2.74$ for all pools for all years. For most pools the auction-floor margin tended to decrease from 1922 to 1925. This decrease was due to an increasing bankers' valuation price and a decreasing auction-floor price for some pools, 
TABLE 46.-Comparison of auction-floor price per 100 pounds with bankers' valuation committee price and with payments by the association to members prior to receivership

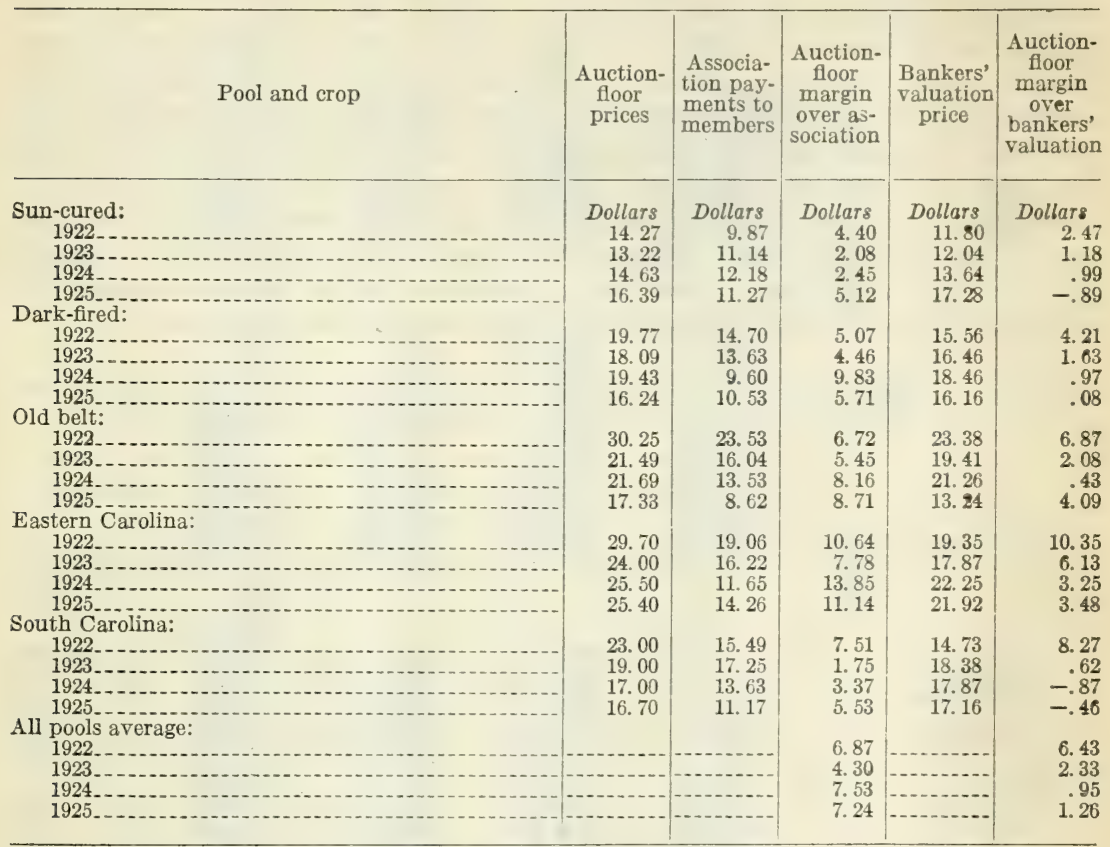

Sun-cured and dark-fired auction-floor prices from Virginia Farm Statistics, 1926 (8, p. 82); auction-floor prices for other areas from Department of Agriculture Yearbooks.

In no instance did the association remit to its members for any year or pool a better average price for all grades than was paid by the auction floor, although it may have done so for some grades. The auction-floor margin was usually the smallest in the sun-cured pool, because the association closed out most of its sun-cured tobacco and because the auction-floor sales margin over the bankers' valuation price was the smallest in the case of sun-cured tobacco. In eastern Carolina, with its wide margin of the auction-floor prices over the association basic price, the prices paid to growers were much higher from the auction-floor houses. Despite the smaller number of payments to members for the crops delivered to the association during the later years of its operation, there was no large widening in the auction margin over association payments for all pools. This was at least partly because of the lowering of the auction-floor prices in some pools from 1922 to 1925 .

In Table 47 are shown the gross average price, the total deductions, and the net amount available to farmers under the two systems. In every pool except one, the 1925 old belt, the net amount available to grower's under the auction-floor system was ligher, sometimes considerably higher, than the amount available under the cooperative marketing system. Further deductions were made from the net prices available to members in order to build reserve funds for contingencies and for a guarantee of the obligations of the 
warehousing corporations. ${ }^{48}$ The members retained equities in these reserve funds, which must therefore be regarded in the nature of an investment of members' funds. But members were in urgent need of ready cash and the net amount remitted to them is thus of importance. These amounts are shown in Table 46. Members were paid only one advance in 1925 equal to 65 per cent of the bankers' valuation. Figure 20 shows the average calculated price per 100 pounds remitted to the tobacco growers, by crops and pool areas, through the auction-floor sale method and through the association. The fact that the net prices per 100 pounds remitted to farmers under the auction-floor system were much higher than those under the association's system was an important factor in increasing the dissatisfaction among members during the last three years.

TABLE 47.-Comparison of net amounts per 100 pounds available through auction floor and association after deducting selling charges

\begin{tabular}{|c|c|c|c|c|c|c|c|c|}
\hline \multirow{2}{*}{ Area, or pool, and price } & \multicolumn{2}{|c|}{1922 crop } & \multicolumn{2}{|c|}{1923 crop } & \multicolumn{2}{|c|}{1924 crop } & \multicolumn{2}{|c|}{1925 crop } \\
\hline & $\begin{array}{l}\text { Associ- } \\
\text { ation }\end{array}$ & $\begin{array}{c}\text { Auction } \\
\text { floor }\end{array}$ & $\begin{array}{l}\text { Associ- } \\
\text { ation }\end{array}$ & $\underset{\text { floor }}{\text { Auction }}$ & $\begin{array}{l}\text { Associ- } \\
\text { ation }\end{array}$ & $\underset{\text { floor }}{\text { Auction }}$ & $\begin{array}{l}\text { Associ- } \\
\text { ation }\end{array}$ & $\begin{array}{c}\text { Auction } \\
\text { floor }\end{array}$ \\
\hline $\begin{array}{l}\text { Sun-cured: } \\
\text { Gross price.....- } \\
\text { Selling charges.- }\end{array}$ & $\begin{array}{c}\text { Dollars } \\
12.33 \\
2.14 \\
\end{array}$ & $\begin{array}{r}\text { Dollars } \\
14.27 \\
.83 \\
\end{array}$ & $\begin{array}{c}\text { Dollars } \\
12.83 \\
1.57 \\
\end{array}$ & $\begin{array}{r}\text { Dollars } \\
13.22 \\
.80\end{array}$ & \begin{tabular}{|c|} 
Dollars \\
14.02 \\
1.50
\end{tabular} & $\begin{array}{r}\text { Dollars } \\
14.63 \\
.84\end{array}$ & $\begin{array}{r}\text { Dollars } \\
16.32 \\
1.77\end{array}$ & $\begin{array}{r}\text { Dollars } \\
16.39 \\
.89\end{array}$ \\
\hline Net price... & 10. 19 & 13.44 & 11.26 & 12.42 & 12.52 & 13.79 & 14.55 & 15. 50 \\
\hline $\begin{array}{l}\text { Dark-fired: } \\
\text { Gross price.....- } \\
\text { Selling charges.. }\end{array}$ & $\begin{array}{r}17.29 \\
2.05 \\
\end{array}$ & $\begin{array}{r}19.77 \\
.74 \\
\end{array}$ & $\begin{array}{r}18.61 \\
2.68 \\
\end{array}$ & $\begin{array}{r}18.09 \\
.70 \\
\end{array}$ & $\begin{array}{r}19.02 \\
4.98 \\
\end{array}$ & $\begin{array}{r}19.43 \\
.74 \\
\end{array}$ & $\begin{array}{r}16.65 \\
1.82\end{array}$ & $\begin{array}{r}16.24 \\
.66\end{array}$ \\
\hline Net price.. & 15.24 & 19.03 & 15.93 & 17. 39 & 14.04 & 18.69 & 14.83 & 15.58 \\
\hline $\begin{array}{l}\text { Old belt: } \\
\text { Gross price....... } \\
\text { Selling charges... }\end{array}$ & $\begin{array}{r}26.25 \\
2.54 \\
\end{array}$ & $\begin{array}{r}30.25 \\
1.01 \\
\end{array}$ & $\begin{array}{r}20.88 \\
3.75 \\
\end{array}$ & $\begin{array}{r}21.49 \\
.79\end{array}$ & $\begin{array}{r}23.71 \\
4.63 \\
\end{array}$ & $\begin{array}{r}21.69 \\
.79 \\
\end{array}$ & $\begin{array}{r}22.90 \\
2.34\end{array}$ & $\begin{array}{r}17.33 \\
.68\end{array}$ \\
\hline Net price.-. & 23.71 & 29.24 & 17.13 & 20.70 & 19.08 & 20.90 & 20.56 & 16.65 \\
\hline $\begin{array}{l}\text { Eastern Carolina (new belt): } \\
\text { Gross price... } \\
\text { Selling charges. }\end{array}$ & $\begin{array}{r}22.89 \\
2.70 \\
\end{array}$ & $\begin{array}{r}29.70 \\
.99 \\
\end{array}$ & $\begin{array}{r}21.33 \\
3.45 \\
\end{array}$ & $\begin{array}{r}24.00 \\
.85 \\
\end{array}$ & $\begin{array}{r}25.01 \\
6.26 \\
\end{array}$ & $\begin{array}{r}25.50 \\
.89 \\
\end{array}$ & $\begin{array}{r}22.42 \\
4.86 \\
\end{array}$ & $\begin{array}{r}25.40 \\
.89 \\
\end{array}$ \\
\hline Net price... & 20.19 & 28.71 & 17.88 & 23.15 & 18.75 & 24.61 & 17.56 & 24.51 \\
\hline $\begin{array}{l}\text { South Carolina: } \\
\text { Gross price...- } \\
\text { Selling charges. }\end{array}$ & $\begin{array}{r}19.24 \\
2.98 \\
\end{array}$ & $\begin{array}{r}23.00 \\
.83 \\
\end{array}$ & $\begin{array}{r}22.06 \\
4.18 \\
\end{array}$ & $\begin{array}{r}19.00 \\
.73 \\
\end{array}$ & $\begin{array}{r}20.48 \\
4.98 \\
\end{array}$ & $\begin{array}{r}17.00 \\
.69 \\
\end{array}$ & $\begin{array}{r}20.52 \\
4.56\end{array}$ & $\begin{array}{r}16.70 \\
.67 \\
\end{array}$ \\
\hline Net price... & 16.26 & 22.17 & 17.88 & 18. 27 & 15.50 & 16. 31 & 15.96 & 16. 03 \\
\hline
\end{tabular}

Sun-cured and dark-fired auction-floor prices from Virginia Farm Statistics 1926 (8, p. 82); auction-floor prices for other areas from Department of Agriculture Yearbooks, 1923-1926.

Although it is not possible to compare accurately the gross prices per 100 pounds obtained through the association and through the auction floor, it is clear that the costs of operation were much greater under the cooperative system, partly because the two systems do not render comparable services. A cooperative marketing association that pools its sales, performs such services as grading, redrying, storing, financing, bargaining, training the members as to type and quality of production, prizing, transporting, and assembling in large lots. The auction-floor warehouse merely offers a sales service in the form of one kind of sale at a specific time $(6, p .288)$. It is not

\footnotetext{
${ }^{48}$ See Table 26, p. 63.
} 


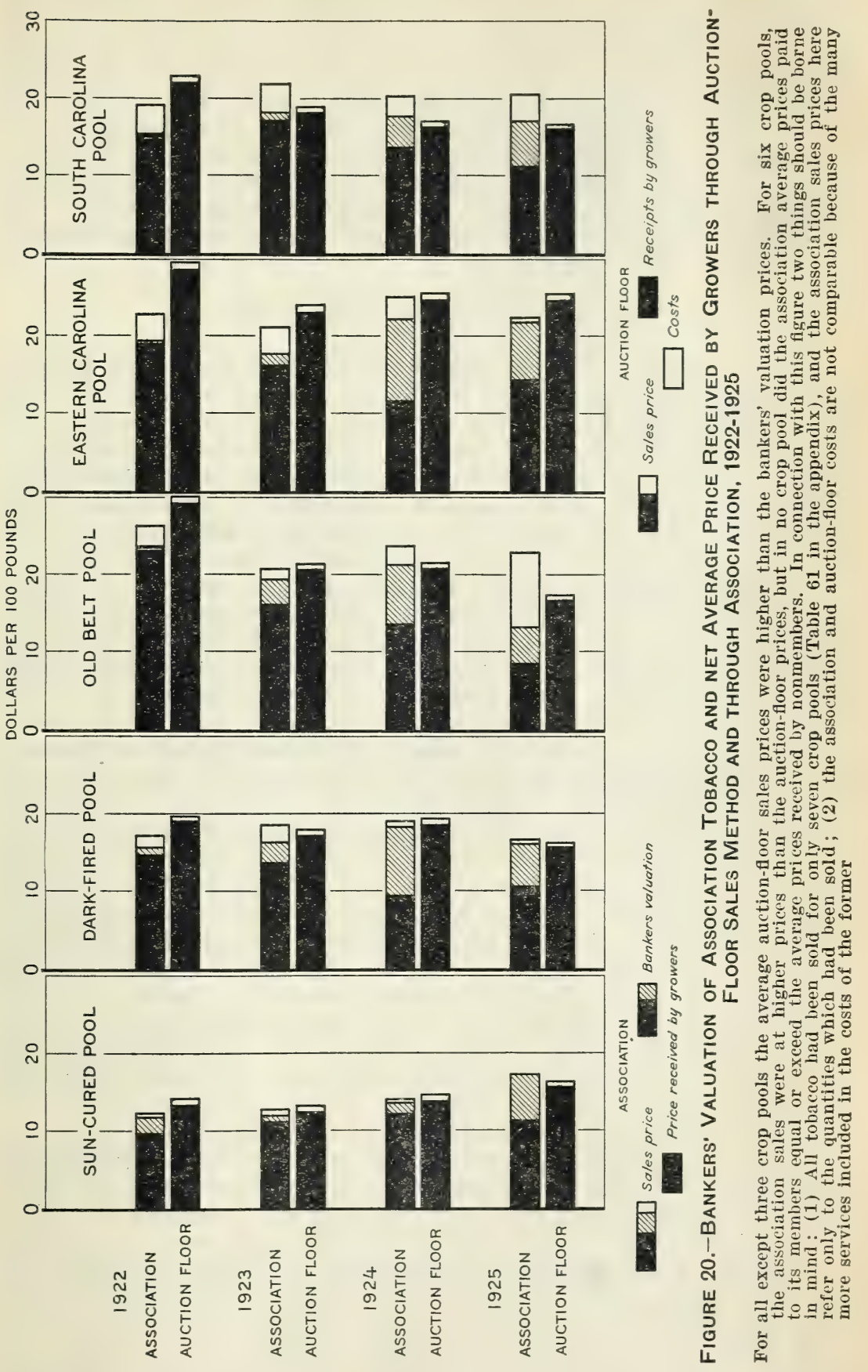


possible so to separate the different costs that valid comparisons can be made for the performance of the same services. Cooperative costs will usually be higher than the costs of private marketing channels because of the quality and number of services rendered. Although a cooperative should be operated economically it should be able to render helpful services to its members which will immediately or ultimately assist them financially. But in this case it would seem that the redrying of large quantities of tobacco decreased the final prices paid to members. Far from improving the bargaining position of the association, its redrying policy tended to place it in a more disadvantageous position owing to the accumulation of large stocks of low-grade tobacco.

\section{OPPOSITION TO THE ASSOCIATION}

It was inevitable that a cooperative tobacco marketing association formed in an area where a different method of marketing had existed for a long time would encounter opposition. This opposition naturally came from the leaf dealers, warehousemen, and buyers of the large tobacco companies, who realized that if this association were successful, the auction system of marketing would eventually be displaced and they would lose their positions and business. The association was also opposed by the tobacco manufacturers and by merchants, bankers, and other business men in some of the larger and more important tobacco markets. There was sharp competition of interests outside of and opposed to the association. This competition, unfriendliness, and opposition was a large factor in causing dissatisfaction on the part of members and gave rise to some of the other difficulties of the association.

The intentional or artificial raising of tobacco prices on the auction floors in attempts to defeat the association, or the raising of prices there because the existence of the association reduced the quantity of tobacco available for outside purchase, caused much dissatisfaction, disloyalty, and nondelivery among the members. The rapid increase in production in new and existing localities, the decreased foreign demand for certain types, the lack of active competition for all grades, all worked to affect adversely the success of the attempt of the tobacco growers of Virginia and of North Carolina and South Carolina to market their tobacco cooperatively.

The opposition of the four opposing groups and reasons therefor are discussed separately. These groups were: (1) Warehousemen, (2) buyers, (3) tobacco manufacturers, and (4) merchants and bankers in certain tobacco markets.

Perhaps the most intense and effective opposition came from warehousemen and trade associations of warehousemen. These saw themselves with idle warehouses if the association were successful. Different methods were used to undermine the morale of the members: Special effort to get high prices for split crops of tobacco, predictions of the failure of the association, spread of propaganda in regard to the excessive salaries and in regard to the integrity and honesty of the management, and other methods were reported to have been used to break down the association. Some boards of trade and other organizations at tobacco marketing centers waged an incessant, varied and effective warfare against the association. It 
should be pointed out that the large tobacco companies were represented on the various boards of trade. Special funds were solicited for the printing and publication of articles attacking the association. Pamphlets were circulated among the farmers. Many of these publications ostensibly aimed to acquaint farmers with the advantages of the auction system of marketing but they largely degenerated into vindictive and defamatory statements against the association. The large companies contributed directly or indirectly to these publications $(12, p . r 0)$. Some of the opposing organizations were accused of going so far as to furnish counsel in support of members against whom the association had taken legal action for nondelivery of tobacco.

At least some of the large tobacco manufacturers were unfriendly and refused to buy from the association. This made it impossible to sell tobacco promptly and to make final payments to members within a reasonable time. Many members were entirely dependent upon returns from their tobacco for a livelihood. The attitude of the comparatively few large dominating tobacco companies was one of the greatest problems which faced the association. 'The Federal Trade Commission found no evidence of their having taken any active measures to combat the association, and the commission expressed the opinion that the two companies which refused to patronize the association were justified in purchasing all of their leaf requirements on the auction floors, if they preferred to buy there (12). It would appear, however, that the refusal of these companies to purchase from the association was largely instrumental in causing ultimate failure. It was among the local representatives of these companies that the association met with its most severe and most effective opposition. The large tobacco companies disclaimed all part in the actions of their leaf buyers, and some companies claim to have advised their buyers to take an indifferent attitude and not to issue statements attacking the association. That this advice was not effective, even if it was given seriously, is seen by the findings of the Federal Trade Commission.

The buyer representatives of certain companies stated at every opportunity that the companies they represented refused to buy from the association and that it was bound to fail. They encouraged and induced members to become disloyal by paying somewhat higher prices for "split-crop" tobacco. They encouraged farmers to believe that the association conld not and would not pay them for tobacco delivered. They took every legitimate measure to cause members to lose faith in their organization. Buyers for the companies that purchased heavily from the association also took an active part in opposing the association. Many professional and business people in both country and town were influenced by this propaganda; many who previously had been in favor of the cooperative movement became either indifferent or actively opposed to it.

Many bankers and "time merchants" were opposed to the association and helped indirectly to wreck it by encouraging and forcing members to break their contracts. Many of the bankers pursued this policy because they were afraid of losing the accounts of the 
large companies if they supported the association. So great is the importance of the large tobacco companies and the tobacco trade in the South that large groups of independent merchants and bankers are afraid to incur their displeasure. The association was opposed in some of the smaller markets because it took charge of all the warehouses, and thus caused the nonmembers to haul their crops to other markets where they also did their shopping. Trade during the tobacco-delivering period is important and lucrative because it is then that the growers have cash and do most of their buying of supplies for the coming year.

Previous to the formation of the Tobacco Growers' Cooperative Association, because of the advent of good roads and autotrucks in parts of the tri-State area, there had been a trend toward the development of a few large tobacco markets instead of the many small markets and receiving places. The cooperative not only used many of the lesser receiving points but it reopened some which had closed during the time of the auction system. The larger markets, like Wilson and Winston-Salem in North Carolina, felt that this prevalence of many small markets would interfere with the centralization of markets and thereby retard their derelopment. As a consequence these large markets were hostile to the association.

During the organization period the attitude and attacks of some of the writers and speakers who were working for the cooperative tended to antagonize some groups who otherwise might not have openly and actively opposed the association. Later, every mistake or suspicion of a mistake was capitalized by the opponents of the association to discredit it, and this type of propaganda was given wide publicity among the growers. Thousands of dollars were spent in propaganda to defeat the organization. Gradually the tactics of those opposed to the association triumphed and their forces increased in strength. Soon the whole of the tobacco territory of the three States was divided into two groups, proassociation and antiassociation. The forces arrayed against the association gained strength from members who had violated their contract. The attacks of the opponents of the association contributed largely to the breakdown of the membership morale. If members had delivered their tobacco, as they had undertaken to do, the association might have succeeded, but when during the first year many failed to do this the result was inevitable, in spite of the tremendous sacrifices and heroic efforts made by the more loyal members and leaders.

\section{PROGRESS DURING OPERATION OF THE ASSOCIATION}

\section{CHANGES IN POLICIES}

In 1922 the members, directors, and officials of the Tobacco Growers' Cooperative Association had much to learn. The members were unaccustomed to marketing their products cooperatively. The practicability of the cooperative marketing of tobacco had not yet been tested. An organization had to be planned and brought into existence which would perform a variety of functions for the tobacco grower. This organization would need to be strong and beyond criticism in order to meet the attacks which its existence was certain to provoke from the established tobacco-marketing agencies. 
In addition there were many policies and practices to be worked out in detail.

The association made mistakes, many of them. However, many of these mistakes were corrected when the need was felt. By the time the association had passed into the control of receivers it had, to some degree at least, corrected the majority of its errors, but some were irreparable in whole or in part. Following is a list of some of the most frequent criticisms of policies, the date on which the policy began, and the date and correction of the policy, if any change or correction was made. The criticisms given here are considered some of the most valid. Those with no foundation of fact are not included.

1. Purchase and lease of unnecessary warehouse space (1922); corrected January 15,1923 , by lease or sale and cancellation of contract. ${ }^{49}$

2. Payment of excessive prices for warehouses (1922) ; correction-practically all warehouses owned were purchased during the first year; only one was purchased after the second year.

3. Salaries of officials excessive (1922); these were voluntarily reduced, first in 1923 and each year thereafter, from $\$ 206,774.98$ in 1922 to $\$ 74,283.21$ in 1925.

4. Salaries of employees too high (1922) ; corrected in 1923 by a gradual reduction in average salaries of lesser officials and employees.

5. Excess in personnel, especially in warehouse department (1922) ; corrected in 1923 by a consolidation of some positions and a reduction in total number of employees.

6. Redrying by officials of the association (permission given June 9, 1923) ; beginning March 10, 1925, the association operated its own redrying plants in time for the 1925 crop.

7. Secrecy in regard to the affairs of the association (1922); corrected March 18, 1924, by the adoption of a "pitiless publicity" policy in regard to its affairs.

8. Field service work inadequate (1922); the field service department was enlarged March 18, 1924, and has been strengthened during the succeeding years.

9. Advances on tobacco too small (1922); this policy was changed during 1923 and 1925. From 40 per cent of the bankers' valuation for the 1922 crop, the payments were advanced to 50 per cent in 1923 and 1924, and to 65 per cent in 1925.

10. Payments too slow and far between (1922) ; since 1924, the association has attempted to make payments before all the tobacco has been sold; also, the agricultural credit corporations have been formed.

11. Inability of members to be released from contracts (1922); no change.

12. Refusal to sell green tobacco to dealers (1924); no change.

13. Directors hired as officials on salaries (1922); the number has decreased from 9 , in 1922 , to 4 , in 1925 .

14. Dissatisfaction with grading (1922); since 1923 a continuous effort has been made to avoid unfairness by the supervision of graders:

15. Objections to Watkins and Patterson; resignations accepted March and April, 1926.

16. Too much litigation and legal expense (1922); on March 18, 1924, the "association adopted the policy of "diplomatic persuasion" instead of threats and legal action.

17. Arbitrary changing of grade prices on several eastern Carolina markets (1923) ; this policy was corrected within a few days by returning to first grade prices.

18. Too many high-priced automobiles owned by the association ${ }^{50}$ (1922) ; on December 22,1925 , the association reached the decision that no more automobiles were to be purchased, those on hand were to be sold, and henceforth employees hired would furnish their own cars.

40 The association was purchasing and leasing warehouses in some markets during its first years and at the same time was selling and subleasing warehouses in other localities.

50 Of 48 automobiles purchased in $1922-23,2$ cost between $\$ 1,500$ and $\$ 2,500 ; 18$ cost between $\$ 500$ and $\$ 700 ; 28$ cost less than $\$ 500$. Of 59 automobiles purchased during $1923-24,7$ cost over $\$ 1,000$; all other cost less than $\$ 700$. 
19. Warehoure officials and manager's incompetent and lacking in tact and courtesy (1922); since 1923, there has been a gradual elimination of the officials criticized.

20. Tuo much overhead expense (1922); there has been a gradual reduction in total overhead expenses from $\$ 2,405,658.59$ for the 1922 crop, to $\$ 1,385,303.79$ for the 1925 crop. However, there has been an increase in overhead expense per hundred pounds of tobacco received.

21. No full-time general manager (1922); a general manager was elected in April, 1924, who was succeeded in May, 1926, by an appointed board of managers. ${ }^{51}$

22. Too many departments and lack of coordination among departments (1922); the warehouse and field service departments were consolidated on March 10, 1925.

23. Lack of foreign sales contacts (1922) ; a commission was sent to Europe, in 1223 , to make sales contacts.

24. Separation of offices at Raleigh, N. C., and Richmond, Va. (1922) ; no change.

\section{ATTEMPTS AT REORGANIZATION}

During the years 1925 and 1926 attempts were made at organizing four separate associations in the tri-State area. These associations were to be: The Sun Cured Tobacco Growers of Virginia, the Virginia Dark Tobacco Growers' Cooperative Association, the Old Belt 'Tobacco Growers' Cooperative Association, and the South Carolina Belt Tobacco Growers' Cooperative Association. The associations were to be organized on a more or less similar basis with similar terms in the agreements and marketing agreements. These associations were to begin operation immediately following the expiration of the then-existing association and to operate for the five years, 1927 through 1931. Organization committees had been formed and membership campaigns launched without the help of the old association. Either because of failure to secure a sufficient percentage of the crop (only 28.2 per cent was signed in South Carolina) or because of inadvisability of attempting to secure members during the receivership suits and after the receivership, all of the attempts were given up or postponed.

In the attempts at reorganization the policies of the organization committees were to avoid the mistakes of the old association and to benefit by the experiences learned through the four years of operation. The changes in many of the policies are those which had already been made in the Tobaceo Growers' Cooperative Association.

\section{RECEIVERSHIP GRANTED}

The receivership for the association was granted by the United States District Court for the Eastern District of North Carolina, June 19, 1926. The association was solvent at that time, but, because it had lost the confidence of its members and because of the

51 Upon the resignation of the general manager in April, 1926, the board of directors appointed a committee from its members of one representative from each of the three States. This committee assumed all duties of a general manager of the association, and was empowered to make all changes found necessary in the affairs of the association, and to investigate and recommend for appointment a general manager of the association. This committee of throe, on May 18, 1926, presented a resolution, which was adopted by the board of directors, vesting the general management of the association in a committee of five, consisting of the three directors, of the naming committee, and two other advisory members. This board of managers had rested in it unlimited power to conduct the affairs of the association and to act for and in behalf of the association, subject to the control of the board of directors and subject to the charter and by-laws of the association. In addition, a financial and business advisor to the board of managers was appointed. This advisor and one of the advisory members of the board of managers were to be paid salaries of $\$ 10,000$ and $\$ 6,000$ per year, respectively. 
uncertainty whether it would obtain a sufficient quantity of the 1926 crop to justify setting up a receiving system, after a vigorous court battle the court considered it advisable to order receivership and release the growers from their contracts. ${ }^{52}$

This order came as a surprise, as it was generally understood that the court would refuse to grant the petition for receivership. The association's directors and creditors opposed receirership, believing it to be unnecessary and contrary to the best interests of the members. The suit for receivership is reported to have been instituted mainly by contract violators and others interested in the clissolution of the association. ${ }^{53}$

Several reasons have been advanced in justification of the receivership which, in the light of subsequent developments, should carry considerable weight. The more important of these are the following:

1. Deliveries had fallen to such a small percentage of the crop as to make the continued operation impracticable and uneconomical.

2. Practically all the tobacco had been pleclged as coilateral for loans, and there was but little additional collateinl which could be used to secure funds to pas the principal and interest upon the obligations of the wirelousing corporations, which would soon mature.

3. With the opening of the 1926 season, the open-market price for tobacco, particularly the Yirginia dark-fired, declined so much below the banker's' raluations that the interests of the creditors would have been seriously endangered, and it is probable they would hare been forced to ask for a receirership.

\section{CAUSES CONTRIBUTING TO FAILURE}

The association had failed to meet the expectations of its members, and was discredited throughout the Tobacco Belt. Although financially solvent, it had failed as a marketing organization. Many factors contributed to this failure, but it is difficult if not impossible to assign any of them a definite rank among the causes of failure. Nerertheless it became evident in the study of the association that there were certain factors in the promotion, organization, operation, and conditions surrounding the operation of the association which were of fundamental significance. These factors or causes of failure may be placed under four general headings: (1) Conditions among tobacco growers, (2) policies and practices cluring the organization of the association, (3) mistakes in policies and in management, and (4) market conditions and commercial interests unfavorable to the cooperative marketing of tobacco in the triState area.

Disloyalty among the members was rampant from the beginning of the association, and membership defections increased as the years passed. This failure of the members, whether voluntary or involuntary, to live up to their contracts was undoubtedly one of the most important causes leading to the failure of the organization. This disloyalty, especially much that occurred cluring the first years, may be attributed largely to the economic, social. and educational conditions of the tobacco farmers in the tri-State area. The percentage of tenancy is very high; tobacco is often the only cash crop; credit facilities are limited and most unsatisfactory. The 
growers are both whites and negroes; many have little education; a relatively large percentage are illiterate. They were, with few exceptions, inexperienced in cooperative marketing and had little understanding of its principles, possibilities, limitations, and necessities. These conditions among a large proportion of the farmers made members peculiarly susceptible to the lure of higher cash prices prevailing on the open warehouse markets and to the insidious and effective attacks of the opponents of cooperative tobacco marketing. The low initial advances at first, and later the delay in making further advances and final settlements, served to aggravate a situation which was already distressing, partly because of the heavy indebtedness resulting from the unsatisfactory prices of tobacco in 1920 and 1921, and partly because of the higher standard of living acquired during the war years. It has been maintained by many that the faith and loyalty of the members were destroyed by the many evidences of mismanagement and because of alleged unwise or dishonest policies of the officials and directors. However, many members failed to deliver the first year before they could have been aware of any policies which might have alienated their support and cooperation.

Economic and educational conditions tend to mitigate the blame of the disloyal member for his contribution to the failure of the association. But many members are open to censure for their failure to support their organization. Unscrupulous members violated their contracts, not through necessity, but through the desire for financial gain. Instead of attempting to remedy mistakes, they often became opponents of their own interests. These members failed to see that future reward could be gained only through some present sacrifice, or they were unwilling to make that sacrifice. To them, and to the nonmembers who fought against the association or profited by its existence, it can only be said that they must apparently remain content with the prices and method of sales of the auction-floor sales system.

Many and lasting were the mistakes in the policies and practices followed during the membership campaign and organization period. The members were allowed, if not led, to believe that an association would have virtually monopoly control of the tri-State tobacco situation. Extravagant promises and promises not possible of fulfillment were made. In many cases the interests not in favor of the cooperative marketing of tobacco were unnecessarily antagonized. The methods of obtaining members and of estimating deliveries, and the failure to select only members who could live up to their contracts were sure to result in lower deliveries than anticipated. Contracts not revocable resulted not only in nondelivery but in open antagonism of those who wished to be legally released from their contracts. The association covered the tobacco-producing areas of three States and handled five more or less distinct types of tobacco. The conditions of the growers are very diverse in the different territories of these three States. The association was large, it seemed too far away, and too indirect in its relations to its constituting members.

The management of the association made many mistakes, some of which were irreparable. These mistakes were due chiefly to the inexperience of the directors and officials, who were unaccustomed to 
officiating as directors or officials of a large cooperative business. Cooperative marketing of any commodity was comparatively a new principle in this area and the cooperative marketing of tobacco had not been fully tested here or elsewhere. The management was extravagant in purchasing and operating warehouses and in employing personnel. The many attempts to enforce contracts by legal procedure aroused the active enmity of many members who were financially unable to live up to the marketing agreement. Secrecy as to some of the affairs of the association, the changing of grades on some markets, lack of closer contact with the members, and especially the policy of selling only redried tobacco to certain buyers and the policy of redrying by officials of the association were among the factors which contributed to the failure through loss of confidence and support of the members and the public.

The buying of the tobacco of the tri-State area is centered in the hands of a few large tobacco companies. The cooperative association, having failed to secure the good will of these companies, had difficulty in selling its tobacco. Thus it was impossible for the association to make frequent or large payments to its members, many of whom were entirely dependent upon the returns from their tobacco for a livelihood. The auction-floor system of selling was firmly intrenched in Virginia and the Carolinas. There was much opposition to the association from those who would be injured financially if the association were successful. This opposition came from leaf dealers, warehousemen, buyers for the large companies, merchants, bankers, and other business men in some of the larger and more important markets. Paying high prices for split-crop tobacco; predicting the failure of the association; spreading propaganda in regard to salaries paid, extravagance of the officials, honesty and integrity of the management; using as propaganda every misstep of the association, were among the methods reported as being used to break down the association. Many of the bankers and time merchants helped to prevent delivery to the cooperative by encouraging or forcing members to break their contracts. All of this unfriendliness, competition, and opposition was an important factor in causing dissatisfaction on the part of the members and gave rise to some of the difficulties of the receiving and the selling of the members' tobacco.

\section{RESULTS OF THE ASSOCIATION}

\section{BENEFITS DERIVED FROM OPERATION OF THE ASSOCIATION}

The Tobacco Growers' Cooperative Association, in spite of its failure, has to its credit many accomplishments, some of which will have a lasting and beneficial influence upon the conditions and future of the tobacco farmers in Virginia and the Carolinas. Some of the benefits are enumerated below:

At least a basic grading system for sun-cured, dark-fired, and flue-cured tobaccos was promulgated. It proved that tobacco grading and sale by sample is feasible and desirable. Better sorting, grading, and handling of tobacco has resulted on many farms and has continued especially in South Carolina.

Growers have a better knowledge of the relative values of the different qualities of tobacco, and the production of a better quality has resulted in many instances because of this better realization of the quality factor. 
Soundness of the financing of green tobacco under the cooperative marketing system was proved.

Existence of the association seems to have increased prices to nonmembers at leist. Many grower's, as a result of the operation of the association, have learned to watch more closely the economic factors involved in tobacco prices.

IIany growers were shown the need of dirersification of crops and many were encouraged to try it.

Experiences gained in the organization and operation of the association will serve as a guide and warning in any future cooperative movements, since many farmers hare learned, at least to some extent, the principles, possibilities, limitations, and difficulties of cooperative tobacco marketing.

The people hare become better acquainted with the abuses and inequities of the auction-floor system, and the interest and solicitude of many tornspeople have been awakened to the plight of the tobacco growers.

The tri-State association was responsible for much of the enactment of legisiation favorable to cooperative marketing in Virginia, North Carolina, and South Carolina.

Some of the members hare found a bond of brotherhood for a common economic cause.

Eridences of another cooperative movement among the tobacco growers will undoubtedly result in ferrer abuses and better prices on the loose-leaf floor than if no cooperative had erer existed.

\section{HARMFUL EFFECTS OF THE ASSOCIATION}

All the effects of the existence and failure of the association were not beneficial. The following are some of the harmful effects:

Many farmers rere embarrassed financially by the delay in paying their contracted debts either through the fault of the association or through their own because they expected high prices.

Its failure created a pessimistic feeling as to the future of farming and of cooperative tobacco marketing in some areas.

Its existence stimulated the production of tobacco in other areas thus adding to the total supply.

Many loral members in some communities have become antagonized against the nonmembers or contract riolators, and vice rersa, creating a dirision of sentiment among the tobacco growers.

Stocks of tobacco held by the association at the time of receivership, and after, may act to depress tobacco prices as long as these stocks remain unsold.

Some business enterprises, as stores and banks, have been embarrassed because of their loans to members on the security of participation certificates.

\section{FUTURE ORGANIZATION}

One of the most commendable things in connection with the 'Tobacco Growers' Cooperative Association was the loyalty, zeal, and untiring efforts on the part of many of its members, directors, and officials, and other proponents of cooperative marketing. Many of the members were loyal in the face of certain loss and defeat. Many of the directors and officials unselfishly gave all of their available time and effort to make the association a success. Advocates of cooperative marketing who were in no financial way connected with the association and who received no salary or other compensation gave their efforts solely to improve the economic conditions of the farmers of their States.

With these and many other men still believing in the principles of cooperative marketing, it seems inevitable that the cooperative marketing of tobacco will in time return to the tri-State area. A new organization should benefit by the experience of the past. It should be on a different organization and operating basis and should develop a somewhat different relationship with tobacco manufac- 
turers. It is necessary that the new cooperative association be formed on the basis of rendering service both to the grower and to the manufacturer. Economical and efficient handling of large volumes of tobacco from the time the grower delivers his tobacco to the time and place the manufacturer takes it should be the prime purpose of this farmers' organization. It must be organized and operated on an efficient business basis, and must be able to render more services, or better services, or cheaper services to the manufacturers as well as to its grower members than do the other marketing systems.

\section{GROWERS' INTEREST IN COOPERATIVE MARKETING}

In spite of the difficulties that have beset cooperative marketing in the past, it must be recognized that organization on sound business principles offers one of the most hopeful means for improving the condition of the tobacco grower and for increasing the stability of the tobacco industry. There are numerous services which a producers' cooperative organization can perform for the growers and for the industry.

Such an association, for example, if properly organized and operated with the good will and business cooperation of the manufacturers, would have a stabilizing effect on prices throughout the region. (1) It could eliminate the inequalities and discrimination complained of under the auction-floor system. (2) It could initiate and carry out a price policy which would serve to coordinate production and demand. (3) It could effect economies in the assembling, grading, storing, and preparing for manufacture.

The tobacco industry has always been particularly subject to the reaction which follows high prices for any agricultural product. New acreage can be quickly brought into production, and a more or less prolonged period of disastrously low prices have followed periods of prosperity. The experience of the Burley Association demonstrates that a response in increased acreage and production has quickly followed favorable prices. This problem of increased production confronts all cooperative marketing associations, but there are several factors connected with tobacco marketing which make it particularly acute and difficult.

The first difficulty arises from the fact that tobacco must be processed, stored, and aged before it is used in manufacture. Under a system of private sale, the buyers assume the risk and expenses of carrying the crop until it is manufactured. But when a cooperative association comes into the field, there is a tendency on the part of manufacturers and buyers to pass back to the association, at least in part, the burden of carrying stocks not immediately required for manufacture.

The second difficulty is the availability of land suitable for tobacco production, and the comparative ease with which acreage may be expanded. This usually results in an increased acreage following years of high prices for tobacco and a decreased acreage following years of low prices. From the standpoint of permanently profitable production, the established tobacco growers are interested in the stabilization of prices at a level which will reward the normally efficient producer, but which offer little incentive for inexperienceit men on poor tobacco land to enter into competition with them. With 
a fair degree of security from loss due to price fluctuations, progressive growers have an opportunity to reduce their costs and make improvement in production practices which will further increase their profits. Stability in the industry will raise the economic and educational status of the growers, and be conducive to the correction of wasteful methods of producing, assembling, and marketing.

That a fair measure of stability in the production and marketing of some agricultural products can be achieved is shown by the experience of several of the large associations of milk producers, operating with the cooperation of milk distributors. In the Philadelphia area, for example, the dairymen's association, by its price policy and surplus plan, has been able to reduce greatly the seasonal surpluses which formerly resulted in low prices to the producers during the spring and early summer. Its policy of maintaining prices that are profitable to the efficient producer, but that at the same time are not so high as to encourage large increases within the area or to invite the competition of distant areas, has resulted in a price which changes infrequently and only with changes in costs. Although many phases of the production and marketing of dairy products and of tobacco are dissimilar, there is reason to believe that similar stability can be obtained in the tobacco industry under a plan of organization which will be outlined later in this circular.

A tobacco-marketing association can be influential in bringing about a more rapid and wider acceptance of standardized grades. It is generally admitted that the Tobacco Growers' Cooperative Association was successful in this respect. Undoubtedly much progress can be made in the grading, sorting into lots, and further processing of tobacco in order to meet the requirements of the individual manufacturers or exporters.

By the payment of market differentials for quality, an association is able to improve production practices. The net result should be more economical and better production which, in conjunction with the factors already discussed, will tend to put the industry on a more stable basis.

Finally a marketing association can perform a number of incidental but important services. It can, for example, through the organization of agricultural credit corporations, assist its members in obtaining production credit from the intermediate credit banks, at lower rates of interest than from other sources. In addition, such an association should be able to represent the growers in all matters that involve relationship between the producers and governmental agencies, transportation companies, financial agencies, and other groups.

\section{MANUFACTURERS' INTEREST IN COOPERATIVE MARKETING}

Like the grower, the tobacco manufacturer is interested in the stabilization of supply and price. He is interested in buying at the lowest possible price, but his long-time interests are not served by extremely low prices which drastically reduce acreage and result in a temporary shortage of supplies at high prices. The grower is best able to plan his production practices so as to operate economically and efficiently, when he has reasonable assurance regard- 
ing the price he will receive for his product. The manufacturer, likewise, can best formulate his manufacturing and sales policies, when he knows the probable cost of his raw material. There seems to be no question but that stabilization of production and marketing conditions would benefit the manufacturers.

The manufacturer would also benefit from more economical and efficient production. The production of improved types and varieties certainly would be to his advantage, even though competition for the most desirable grades would continue to return higher prices to the producers of these grades. The benefits of economies in production, theoretically, would be shared by the growers, the manufacturers, and the consumers.

A second advantage of an efficiently operated growers' cooperative association to the manufacturers comes from greater economy in acquiring their supplies of leaf tobacco. Assembly of tobacco in large lots by the association enables the manufacturer to obtain those lots which meet his requirements with a minimum of purchasing expense. He also has a somewhat wider selection and more assurance of obtaining exactly the types and grades he requires without the necessity of purchasing tobacco which may not be adapted to his needs. It is felt that the Federal system of standard grades could be used to advantage by the buyers and that the service of the association to its customers should include strict adherence to these grades, and satisfactory adjustments in cases where the buyer's specifications were not met. This policy on the part of the cotton-marketing associations, as one example, has resulted in close and generally highly satisfactory relations with the mills which buy cotton sold by the cooperatives.

It should be clear that it is not desirable, even if it were possible, to maintain tobacco growing as a bonanza industry. Inflated prices bring a reaction because of competition from new producers and new areas, and their general effect is to depress the economic level of the growers. Neither is it desirable that tobacco should continue to be produced under the low economic, social, and educational conditions which characterize so many tobacco districts in the South. Public opinion expressed in laws or regulations may in time demand drastic remedies for the tobacco growers' situation. If such an occasion arises, the tobacco companies will not escape censure. It is much more desirable from every point of view that the industry should be stabilized by the cooperation between these companies and the organized growers. Once the producers and manufacturers are able to see beyond temporary advantages, and to study the welfare of the industry and their own long-time interests, there should be little difficulty in effecting such business cooperation.

\section{A SUGGESTED PLAN FOR THE SUCCESSFUL COOPERATIVE MARKETING OF}

The difficulties experienced by the Tobacco Growers' Cooperative Association indicate that, in the tri-State area at least, cooperative marketing of tobacco can not be successful without business cooperation between the manufacturing companies and the growers' organization. The producers and the manufacturing consumers of leaf tobacco have a common interest in the stabilization of the in- 
dustry. That such stabilization can best be brought about by the establishment of strong cooperative marketing associations has been demonstrated by the experiences described.

It is the purpose of this section to set forth the essential features of a cooperative marketing organization for tobacco which, it is believed, can be operated for the benefit of the growers and the business interests whose prosperity is dependent in a large part upon the purchasing power of these growers, and which can be operated in a manner that will be equitable to the manufacturing companies and the tobacco industry in general.

Such an organization must be based on an agreement or contract between the association and the manufacturers. The details of the contract need not be specified here, but it might include the following general provisions or similar provisions:

(1) The growers' cooperative tobacco association and the tobacco manufarturers, through duly authorized committees representing all parties concerned, would enter inio negotiations with regard to prices to be paid for the various types of tobacco handled by the association and to price differentials applicable to the rarious grades. It probably would be adrisable that the United States Department of Agriculture (with the assistance and cooperation of the growers cooperatire marketing association, manufacturers, and dealers, and of State and Federal agencies) assemble and compile statistics and other information regarding tobacco production, culture, cost of production, shifts or trends in production or types, prices, grades, consumption and marketing, and regarding such other phases of tobacco production and marketing as may be helpful in assisting the association and the tobacco manufacturers in arriving at reasonable and justified prices for each grade. Such prices would apply to all tobacco of the types and grades specified which are produced by members of the association during the current crop year; and sold by the association within 12 months of the acceptance of such prices by all parties; or until such prices are changed or set aside by agreement at a subsequent conference.

(2) Prices and differentials so agreed upon would be for tobacco in green order, sorted in specified lots or grades, f. o. b. at the rarious receiving plants of the association, or at some specified central point.

(3) In the event that the association and the manufacturers are unable to agree upon prices or price differentials, they would submit their dispute to a board of arbitrators whose decision should be final and binding upon both parties.

(4) Disputes regarding the grade, quality, or condition of any lot of tobacco sold under the terms of the contract might be submitted for settlement to licensed Federal tobacco graders, inspectors, or supervisors.

(5) For all warehousing, redrying, prizing, handling, and transportation of tobacco performed by the association an agreed amount per pound would be added to the price paid by the manufacturing companies. Such differentials would take into consideration the costs of performing such additional services, including shrinkage and loss during redrying or other operations, and all other normal and unavoidable losses and costs.

(6) The association would agree to sell and deliver to the manufacturing companies, under the terms and at the prices agreed upon by conference or specified in the contract, all tobacco of the types and grades desired by these companies which has been delivered to it by its members; provided that if all such tobacco is not sold or disposed of within one year, or prior to the conclusion of a conference called to negotiate regarding the price of tobacco grown during the succeeding crop year, then the price schedule for the new crop would also apply to all old-crop tobacco in the possession of the association.

The manufacturing companies, in turn, would agree to purchase from the association, at prices and terms agreed upon. all tobacco of the types and grades required by them for manufacture offered for sale by the association, and to make such purchases exclusively from the association as long as tobacco offered for sale by the association is of the rariety, type, and grade that meets their needs. 
The Tobacco Growers' Cooperative Association of Virginia, North Carolina, and South Carolina was incorporated on February 9, 1922, with the main office at Raleigh, N. C. Relatively low prices for tobacco in 1920 following high prices during the World War, together with a general dissatisfaction with the auction-floor system of selling tobacco and encouragement from some men who believed that relief from the conditions then existing could be secured through farmers' cooperative associations were the principal factors which caused the creation of the association. Nearly 96,000 tobacco growers signed contracts to deliver their tobacco to the association during the four years of its operation.

The association attempted to secure delivery of over half of the Virginia sun-cured, Virginia dark-fired, and flue-cured types of tobacco grown in the three States in which it operated. Conditions, however, were unfavorable to the successful operation of the largescale tobacco cooperative as it was organized and operated. In 1922 , instead of handling the anticipated 50 to 60 per cent of the tobacco crop of the three States, it received only 35.4 per cent. In 1923 the receipts decreased to 28.5 per cent; in 1924 to 22.9 per cent; and in 1925 to 14.6 per cent. In the new-belt area of North Carolina the receipts were only 19.5 per cent during 1922, the first year of operation, and in 1925 they had decreased to the low percentage of 5.16 per cent. In June, 1926, at the end of its fourth year, after receiving a total of over $531,000,000$ pounds of tobacco valued at over $\$ 100,000,000$ from its members, the association was put in the hands of receivers.

The failure of the association was not due to any one cause but to many causes. Some of these alone might, in time, have resulted in the downfall of the association; others merely hastened the failure.

These causes of failure may be grouped under four general headings: (1) Conditions among tobacco growers, (2) policies and practices during the organization of the association, (3) mistakes in operating policies and in management, and (4) market conditions and commercial interests unfavorable to the association.

In spite of its failure, and in spite of some of the temporarily harmful effects, the association has to its credit many accomplishments some of which will have a lasting and beneficial influence upon the conditions and future of the tobacco growers of Virginia and the Carolinas.

There is reason to believe that a new organization, or organizations, will eventually be formed in the tri-State area, built upon the principles of service, stability, and economy for both the tobacco growers and the tobacco manufacturers, and with cooperation between these two groups instead of opposition.

\section{APPENDIX}

\section{ARTICLES OF INCORPORATION OF TOBACCO GROWERS' COOPERATIVE ASSOCIATION}

We, the undersigned, a majority of whom are residents and citizens of the State of North Carolina, engaged in the production of agricultiral pioclucts. do hereby voluntarily associate ourselves together for the purpose of forming 
a cooperative marketing association, without capital stock, under the provisions of the cooperative marketing act of the State of North Carolina.

The name of this association shall be Tobacco Growers' Cooperative Association.

The purposes for which the association is formed are:

a. To promote, foster, and encourage the business of marketing tobacco cooperatively; to minimize speculation and waste in the production and marketing of tobacco and tobacco products; to stabilize tobacco markets; to handle cooperatively and collectively the problems of tobacco growers;

$b$. To engage in any activity in connection with the grading, handling, processing, drying, storing, shipping, warehousing, manufacturing, and marketing of tobacco or tobacco products of the association and of its members; and in the financing of any of said operations ;

$c$. To purchase and sell any tobacco or tobacco products of its members; and to purchase and sell to its members machinery, equipment, or supplies used in any of the above-mentioned activities, either by the association or by the members thereof;

$d$. To borrow money and to make advances to the members of the association; and to incur indebtedness without limitation;

$e$. To lend money to the members of the association, in connection with any of the said activities, upon any adequate security; and to accept as collateral for any such loans, warehouse receipts, mortgages, or any other kind of property or security permitted by law;

$f$. To sell, issue, discount or borrow money upon any commercial paper or negotiable instruments, or promissory notes, or warehouse receipts, or mortgages, or bonds, or any other kind of property or security owned by or under the control of the association;

$g$. To act as the agent, representative, or broker of its members in any of the above activities ;

$h$. To purchase, or otherwise acquire, and to hold, own, exercise all rights of ownership over, sell, transfer, or pledge, or guarantee the redemption or retirement of and the payment of dividends or interest on shares of the capital stock, or bonds, or securities of any corporation or association engaged in the processing, or drying, or grading, or storing, or shipping, or handling, or manufacturing, or marketing of any tobacco or tobacco products, in furtherance of any of the above-mentioned activities ;

$i$. To buy, hold, lease, construct, contract for the use of and exercise all privileges of ownership over such real or personal property as may be necessary or convenient for the conduct and operation of any of the business of the association.

$j$. To acquire, own, develop any interest in patents, trade-marks or copyrights, connected with the handling, or manufacturing, or marketing of the tobacco or tobacco products of the association or its members ;

$k$. And to do each and everything necessary, suitable, or proper, in the judgment of the directors of this association, anywhere, throughout the world, for the accomplishment of any of the purposes or attainment of any one or more of the objects herein enumerated, or which shall at any time appear conducive to or expedient for the interest or benefit of the association and the members thereof, and to contract accordingly;

$l$. Tobacco Growers' Cooperative Association shall make no profits for itself from any of its activities; but all oi its operations shall be for the mutual benefit of its members only and shall be cooperative in character.

The operations and activities of this association shall be limited to activities arising out of the processing, drying, grading, shipping, storing, warehousing, handling, manufacturing, and marketing of the tobacco or tobacco products of the association and of its members only and to the financing of any of the said operations.

The association shall not be permitted to buy or sell tobacco except from and for its members only and on a standard cooperative basis. It shall not buy or handle any tobacco whatsoever from nonmembers; or be permitted to go in the open market to buy tobacco or any tobacco products whatsoever;

$m$. The association. is expressiy forbidden to do anything with the intent or effect of lessening the production or use or consumption of tobacco; but this association shall do everything within its power to prevent speculation in handling of tobacco and tobacco products and to secure for its members a fair price for their tobacco, or tobacco products, in the markets of the world; and do everything reasonable within its powers to stabilize to a fair level down- 
ward, the prices to be paid by the ultimate consumers; to increase the sale, use, and consumption of tobacco and tobacco products by all possible commercial and merchandising methods ; and to use every possible means to improve this supply and to extend and increase the demand for tobacco and tobacco products.

$n$. This association shall have and exercise all powers, privileges, and rights authorized by the laws of this State and all powers and rights incident thereto.

The place where the principal business of Tobacco Growers Cooperative Association will be transacted is Raleigh, Wake County, N. C.

The term for which the Tobacco Growers Cooperative Association is to exist is twenty (20) years from and after the date of incorporation.

Tobacco Growers Cooperative Association shall be managed by a board of twenty-five (25) directors.

The names and residences of those selected to serve for the first year and until their successors shall have been selected and qualified are:

\section{Name}

Residence

J. A. Brown, Cladbourne, Columbus County, N. C.

G. A. Norwood, Goldsboro, Wayne County, N. C.

J. Y. Joyner, LaGrange, Lenoir County, N. C.

J. H. Coward, Ayden, Pitt County, N. C.

J. V. Cobb, Pinetops, Edgecombe County, N. C.

S. F. Austin, Nashville, Nash County, N. C.

S. T. Peace, Henderson, Vance County, N. C.

E. G. Moss, Oxford, Granville County, N. C.

R. B. Whitley, Wendell, Wake County, N. C.

athgate Jones, Durham, Durham County, N. C.

J. M. Galloway, Greensboro, Guilford County, N. C.

A. L. Bunker, Mount Airy, Surry County, N. C.

Clarence Poe, Raleigh, Wake County, N. C.

W. R. IVest, Axton, Henry County, Va.

F. O. McCormick, Jarra, Pittsylvania County, Va.

T. C. Watkins, jr., South Boston, Halifax County, Va.

N. H. Williams, Chase City, Mecklenburg County, Va.

Joseph M. Hurt, Blackstone, Nottoway County, Va.

M. O. Wilson, Keysville, Charlotte County, Va.

C. W. Wingfield, Naruma, Campbell County, Va.

W. S. Garrett, Bula, Goochland County, Va.

J. H. Quisenberry, Frederick Hall, Louise County, Va.

Bright Williamson, Darlington, Darlington County, S. C.

T. B. Young, Florence, Florence County, S. C.

E. C. Epps, Kingstree, Williamsburg County, S. C.

Tobacco Growers Cooperative Association shall not have any capital stock; but shall admit members into the association upon payment of an entrance fee of three dollars $(\$ 3.00)$ and other uniform conditions.

The voting power of the members of this association shall be equal; and each member shall have one vote only.

The property rights and interests of each member shall be equal; and each member shall have one unit of property rights only.

The private property of the members shall not be subject to the payment of corporate debts; and no member shall be liable for the debts of the association to any amount exceeding the unpaid balance of his entrance fee.

In witness whereof, we have hereunto subscribed our names this 9 th day of February, 1922.

J. A. Brown, G. A. Norwood, J. Y. Joyner, J. H. Coward, J. V. Cobb, S. F. Austin, S. T. Peace, E. G. Moss, R. B. Whitley, Southgate Jones, J. M. Galloway, A. L. Bunker, Clarence Poe, W. R. West, F. O. McCormick, T. C. Watkins, jr., N. H. Williams, Jos. M. Hurt, N. O. Wilson, C. N. Wingfield, W. S. Garrett, J. H. Quisenberry, Bright Williamson, T. B. Young, E. C. Epps.

\section{State of North Carolina,}

County of Wake, ss:

Before me, a notary public within and for said county and State, on this 9th day of February, 1922, personally appeared J. Y. Joyner, known to me to be one of the identical persons who executed the within and foregoing instru- 
ment; and he acknowledged to me that he had executed the same as his froe and voluntary act and deed for the uses and purposes therein set forth.

Witness my hand and official seal the day and year above set forth. [NOTARIAL SEAL.]

$$
\begin{array}{r}
\text { Notary Public in and for the County of Wake, } \\
\text { State of North Carolina. }
\end{array}
$$

My commission expires June 9, 1923. Filed February 9, 1922.

$$
\text { J. BRYAN GRIMES, Secretary of State. }
$$

\title{
TOBACCO GROWERS COOPERATIVE ASSOCIATION AGREEMENT
}

\author{
WE ORGANIZE A NONPROFIT COOPERATIVE ASSOCTATION TO SELL OUR TOBACCO \\ INTELLIGENTLY
}

The undersigned propose to organize a nonprofit association, without capital stock, for the purpose of promoting, fostering, and encouraging the business of marketing tobacco cooperatively; for reducing speculation; for stabilizing tobacco markets; for cooperatively and collectively handling the problems of tobacco growers, and for other pertinent purposes.

\section{WE AGREE WITH EACH OTHER-NO OUTSIDERS IN THIS CONTRACT}

We, the undersigned, in consideration of the premises and of our mutual undertakings and of the agreement of each and every party hereto, do hereby agree as follows, each for himself and collectively for the express benefit of and as the association to be organized:

\section{WE AGREE TO BE MEMBERS}

1. We will become members of the Tobacco Growers' Cooperative Association, a nonprofit association without capital stock, to be organized under the laws of the State of North Carolina, if by July 1, 1921, appropriate legislation has been there enacted; otherwise under the laws of the State of Tennessee.

\section{ONLY GROWERS OR LANDLORDS WHO HAVE TOBACCO TO SELL CAN BE MEMBERS}

2. The association may include in its membership any tobacco grower or the landlord or tenant or lessor or lessee of land on which tobacco is grown, provided the landlord or lessor receives all or part of the rental in tobacco.

WILL HAVE 25 DIRECTORS-THE OFFICE WILL BE AT RAIEIGH, N. C.

3. The affairs of the association shall be controlled by a board of 25 directors, and the office of the association shall be at Raleigh, N. C.

\section{TWENTY-TWO DIRECTORS ARE TOBACCO GROWERS-THERE WILL BE TWENTY-TWO} DISTRICTS

4. (a) The members shall elect 22 directors from among members actually residing and growing tobacco in districts to be fixed equitably and specified by the organization committee on the basis of the tobacco produced by the members actually signed up prior to incorporation.

Each district shall include approximately the same estimated production covered by the members in any other district, but counties within each district shall be kept intact.

\section{EACH TYPE OF TOBACCO WILL HAVE ITS OWN SELLING COMMITTEE}

(0) The directors, among other functions shall be organized into selling committees, according to each general type of tobacco. If there are not three directors growing tobacco of each type, the board shall select growers of such types to act with members of the board on the respective selling committees of three.

Each selling committee shall study the problems of the particular type of tobacco grown by its members and shall act in an advisory capacity to the hoard of directors of the association on the problems and policies affecting such type. 
THE GOVERNORS WILL NAME THREE DIRECTORS TO REPRESENT THE PUBLIC

(c) Three directors shall be persons nominated in writing by the Governors of North Carolina, Virginia, and Suth Carolina, respectively; and, when elected, they shall have full authority as directors, representing primarily the interest of the general public in the conduct of the association.

MEMBERS SHALL HOLD PRIMARY ELECTIGNS TO CHOOSE DELEGATES-DELEGATES SHALL SELECT DIRECTORS IN EACH DISTRICT

5. The members in each county in each district shall meet annually for a primary election, to be held in the county and couducted as, where and when specified by the directors: and shall select one delegate for erery million or majority fraction of a million pounds of tobacco represented in the preceding year by the members in such county. The said delegates shall then meet where, when, and as instructed by the directors and shall select one member in each district to be presented as the nominee to represent such district. Such nominee. must be elected as director at the general meeting.

\section{VOTING BY MAIL}

If unable to attend the members may rote at such primary meeting by: mail: on a signed ballot prepared under directions of the board of directors.

The first primary to select incorporating directors shall be held within 30 . days after completion of the minimum sign-up herein provided for.

\section{DISTRICT ALWAYS TO GIVE FAIR REPRESENTATION}

6. The organization committee, at least 20 days before the first primary meeting, and the directors, by a majority vote, at least 20 days prior to all succeeding primary meetings, shall fix and specify or change the sad districts and the counties included therein, so as to maintain at all times fair and equitable representation of the tobacco-producing counties and districts included in the. membership.

\section{BOARD WILI HAVE AN EXECUTIVE COMMITTEE}

7. The board shall appoint an executive committee of five directors to conduct the affairs of the association, subject to the general control of the board of directors.

\section{LOCAL BRANCHES WILL BE MAINTAINED}

8. Informal local branches of the association shall be created and maintained in every district, county, and central locality. Each district shall have its own officers. who may attend the meetings of the board of directors and act in an. advisory capacity. The association will provide uniform rules for such branches.

ONE MAN-ONE VOTE

\section{Every member of the association shall have one vote.}

\section{ENTRANCE FEE, \$3-CREDIT FOR PAYMENTS TO EXISTING TOBACCO ASSOCIATIONE}

10. Every member shall pay an entrance or organization fee of $\$ 3$.

Members shall receire credit against said entrance fee for whatever amount they have paid in 1920 for membership in the Tobacen Growers' Associations. of Virginia. North Carolina, and South Carolina, in consideration of the agreement of such association to aid actirely in the organization of this Tobacco. Growers' Cooperative Association.

\section{ASSOCIATION WILL HAVE SUITABLE ARTICLES OF INCORPORATION AND BY-LAWS}

11. The association will confine itself to the problems and marketing of tobacco and tobacco products only and for its members only. It shall have su table articles of incorporation and br-laws stating the rurposes and powers of the association; the rights and duties of memlers: manner of forfeiture of membership; value of property interests on withilratral and any other necessary, pertinent, and important points of organization, as determined by the organization committee. 


\section{ORGANIZATION COMMITTEE}

12. The association shall be organized by an organization committee consisting of a chairman, 2 vice-chairmen, a secretary-treasurer, and 22 additional members; and the said organ zation committee may increase its members; elect new members in place of any who may resign or be unable to act ; appoint an executive committee of seven to conduct its detailed affairs; open headquarters; incur necessary obligations and make necessary expenditures; and take such steps as it may deem advisable to secure subscribers for this agreement and members of the association. The secretary-treasurer shall be adequately bonded.

\section{ORGANIZATION COMMITTEE}

Chairman, J. I. Joyner, La Grange, N. C.

Vice chairman, M. O. Wilson, Keysville Va.

Vice chairman, Bright Williamson, Darlington, S. C.

Secretary-treasurer, E. G. Moss, Oxford, N. C.

North Carolina, J. Y. Joyner, La Grange; Clarence Poe, Raleigh; L. S. Tomlinson, Wilson; W. B. Daniel, Henderson; W. G. Lindsay, Reidsville; B. W. Kilgore, Raleigh, director of extension; George Ross, Jackson Springs; J. W. Stephenson, Smithfield; E. B. Crow, Raleigh (and one member to be added).

Virginia, A. J. Houchens, West Point; M. O. W.lson, Keysville; J. H. Warren, Danvill::; C. Gordon, Union Level; H. T. Jones, Burkeville; M. C. Johnson, Monita : C. R. Sanderson, Cartersville; R. W. Fuqua, Prospect; J. H. Quisenberry. Fredericks Hall (appointed to serve as alternate for J. R. Hutcheson, director of extension).

South Carolina, Bright Williamson, Darlington; N. A. McMillan, Mullins; F. A. Burroughs, Conway; T. B. Young, Timmonsville; S. B. Poston, Jacksonville; W. W. Long, Clemson College, director of extension.

Tennessee, J. P. Killebrew, Guthrie, Ky.

\section{EXECUTIVE COMMITTEE}

M. O. Wilson, chairman, Keysrille, Va.; J. H. Quisenberry, Fredericks Hall, Va.; W. W. Long, Clemson College, S. C.; J. P. Killebrew, Guthrie, Ky., for Tennessee; J. Y. Joyner, Raleigh, N. C.; Clarence Poe, Raleigh, N. C.; L. S. Tomlinson, Wilson, N. C.

ONE-HALF OF THE PRODUCTION IN NORTH CAROLINA, VIRGINIA, AND SOUTH CAROLINA MUST BE SIGNED UP

13. (a) If by January 1, 1922, signatures of tobacco growers or persons eligible to membership covering at least one-haif of the aggregate production of tobacco in North Carolina, Virginia, and South Carolina in 1920, shall not have been secured for this agreement, the organization committee shall so notify every subscriber at his address noted below, prior to January 15, 1922, and the subscriber shall have the right to withdraw and to cancel his signature and the agreement signed by him by written notice mailed to the secretary of the organization committee between January 15, and February 1, 1922.

\section{BINDING AGREEMENT}

(b) If signatures of the growers of the said half shall be secured by the said date, January 1, 1922, then this agreement shall be binding upon all of the subscribers in all of its terms and there shall be no right of withdrawal whatsoever.

\section{STARTS WITH 1921 CROP IF YOU SECURE THE SIGN-UP}

(c) If the said one-half is secured prior to July 1, 1921, the organization committee shall proceed to organize the association and handle the 1921 crop as set out in the marketing agreement.

ntherwise the year 1921 shall be deemed omitted from marketing agreement and the year 1922 added thereto and all terms and obligations shall be moved to one year later. 


\section{STATEMENT OF COMMITTEE CONCLUSIVE}

(d) For all matters of production or signatures and for all statements of fact in connection herewith, the written statement of the organization committee, signed by its chairman, shall be absolutely conclusive, with or without notice to the subscriber.

\section{COMMITTEE KEEPS TRUE ACCOUNTS}

14. The organization committee shall keep a full, true, and detailed account of expenditures, including salaries, fees, and costs of every kind; and shall have such accounts audited and render a written report thereof to the board of directors of the association when organized; and shall thereupon turn over to the association any balance remaining in its hands and free of obligation. If it is not so organized, such balance shall be prorated among the signers hereof.

\section{COMMITTEE AUTHORIZED TO GO AHEAD}

15. (a) We do hereby authorize the organization committee as the representative of all the subscribers, to take such steps as it may deem proper, especially in North Carolina, Virginia, South Carolina, and Tennessee, and later in Kentucky and other tobacco-growing States to secure subscribers hereto; and when the adequate number has been secured to hold primary elections and have the signers select delegates to elect the organizing directors from among growers subscribing hereto, together with the three public directors, conforming as closely as possible to the provisions of paragraph 4 ; and to take all steps necessary and advisable to organize the association.

\section{ASSOCIATION TO KEEP UP ORGANIZATION WORK}

(b) The association when organized shall make every reasonable effort to secure signatures of additional growers to the standard marketing agreement, to cover the largest possible percentage of the tobacco crops grown within the United States.

HOW YOU SECURE, FINANCE, AND CONTROL ANY PLANTS YOU MAY NEED FOR CURING, DRYING, PROCESSING, OR STORING ANY TOBACCO

16. (a) After due investigation the association may cause a warehousing or other corporation to be organized in any community or district where any such need is indicated, by written request of at least 100 members, for the purpose of leasing, purchasing, or constructing and operating warehouses, drying or curing plants, storehouses or factories, or other places to handle, treat, process, manufacture, and warehouse or store any or all of the tobacco delivered by members of the association.

\section{APPROPRIATE NAME}

(b) Such corporation shall have appropriate name, indicating the district, and shall have common capital stock and preferred capital stock in amounts estimated as sufficient for their purposes by the directors of the association.

\section{ASSOCIATION CAN NOT PUT UP ANY PLANTS AGAINST DESIRE OF MEMBERS}

(c) The association shall send a written notice to every member in that district, notifying the members of the intention to organize such a corporation. specifying the amount of capital stock involved; uature of plants; location of plants and specific purposes.

The members shall have two weeks within which to signify their dissent or disapproval of such plan. If, within two weeks of the mailing of such notices by the association, the majority fail to file written notices of such disapproval or dissent, the association shall proceed with its program and shall organize the corporation as indicated.

COMMON STOCK HAS ALL THE VOTING POWER-ONLY MEMBERS CAN OWN THIS

(d) The authorized common stock shall exceed in amount the authorized preferred stock. The common stock shall be sold only to members of the asso- 
ciation at par; but no wember shall purchase originally or directly more than $\$ 100$ worth of such common stock. The common stock shall have all the roting power of the corporation.

PREFERRED STOCK HAS NO VOTE, BUT HAS GUARANTEED DIVIDENDS-ANYBODY CAN BUY PREFERRED STOCK

(e) The preferred capital stock shall be divided into five equal classes all bearing 8 per cent cumulative dividends and having similar preferences, subject to retirement with a bonus of 2 per cent, at the rate of one class or one-fifth thereof annually, beginning June, 1923.

The preferred stock may be sold to any person, firm, or corporation whatsoever.

\section{LIMITATION ON STOCK ISSUES}

(f) The original issue of preferred stock shall not exceed 1 cent for each pound of tobacco of the 1920 crop, covered by the membership of that district; but this amount may be increased proportionately as the membership increases.

FUNCTION OF CORPORATIONS AND RELATIONS TO MARKETING ORGANIZATIONS

(g) The association shall make a cross contract with the corporation, providiug substantially as follows: That the corporation shall handle, process, dry, cure, con!lition, manufacture, treat, store, ship, and deliver all as required and directed by the association. the tobacco deirrererl to it by and at the order of the association. Such service $\pi$ ill be on a nonprofit basis; and the colporation shall receire therefor only the actual costs of such operations and amounts, aplortioned over the operations of any one season, sufficient to pay a dividend of 8 per cent on the outstanding common stock and the diridends on the outstanding preferred stock and to retire in each of the five calendar rears, beginning with 1923, one-fifth of the preferrerl stock, or one class thereof; and sufficient amounts for taxes, insurance. depreciation, betterments, and commercial and secondary charges, all as the directors of the association may instruct and limit the corporation and not otherwise. The corporation will agree to do no buying or selling of tobacco whatsoever.

\section{PUBLIC WAREHOUSES}

(h) Any warehouse shall be conducted as a public warehouse, with such charges as may be imposed through an official borly or with such charges as ale generally prevalent in the district; and any profits made from such operations as a public warehouse shall be utilized for payment of overhead expenses of the corporation.

\section{HOW YOU RETIRE PREFERRED STOCK}

(i) The association shall retire each class of preferred stock and pay the dividends on the stock by deductions from the marketing proceeds of the member's within the respective districts in which the warehouses, etc., are built anil ol erated.

If. hotrerer, any central plants are purchased, constructed, or leased, or olerated for the general benefit of sereral or all the districts, such deductions shall be made from the proceerls of the sereral or all districts, as the directors may determine, conclusirely, to conform to the general extent of the beneficial purpose.

\section{GROWERS GET CREDIT FOR ALL DEDUCTIONS TO RETIRE STOCK}

( $j$ ) As the preferred stock is retired the association will calculate the value of the contribution from each grower's tohacco torrard such retirement and towarl parment of dividends on the common and preferred stock: and the corpo:ation will credit and issue from time to time to each member common stork in an equiralent amount at the hook ralue thereof, as conclusirels establisherl by the directors of the corporation, as soon as the aggregate deductions equal the book value of one or more shares. 


\section{MARKETING AGREEMENT IS HERE ACCEPTED}

17. (a) The subscriber agrees (1) to execute, when requested by the association, a marketing agreement in terms substantially the same as those set forth in the agreement herewith embodied; or (2) at the ontion of the board of directors to be bound by the terms of the following marketing agreement.

For such purposes signature to this association contract shall be deemed to all effects the same as signature to the said marketing agreement and as acceptance of the exercise of such ontion by the board of directors. Notice thereof shall be mailed to each subscriber at his address noted below.

\section{THIS IS AN APPLICATION FOR MEMEERSHIP}

(b) The subscriber here applies for membership in the association when organized and expressly agrees that his signature to this association centract and to the marketing agreement, herewith embodied. and to this application for membership shall be irrevocable, excent as provicled in paragraph 13; and that he so agrees, in order to induce other grower's to sign this agreement for his benefit as well as their own general benefit and the puhlic melfare.

Acceptance of this application for membership and of the marketing agreement shall be deemed conclusive, upon the mailing of the notice by the assuciation: and such mailing and notice shall be conclusively established $\mathrm{ly}$ the affidavit of the secretary of the association.

\section{MEMBER'S AGREEMENT WITH THE ASSOCIATION}

The Tobacco Growers' Cooperative Association, a nonprofit association, hereinafter called the association, first party, and the undersigned grower, second party, agree:

\section{THIS IS FOR COOPERATIVE MARIETING}

1. The grower is a member of the association and is helping to carry out the express aims of the association for conperative marketing, for minimizing speculation and waste and for stabilizing tobacco malkets in the intelest of the grower and the public, through this and similar obligations undertaken by other growers.

\section{GROWER SEILS TOBACCO TO ASSOCTATION FOR FIVE YEARS}

2. The association agrees to buy and the grower agrees to sell and deliver to the association all of the tobacco produced by or for him or acquired by him as landlord or lessor, during the Jears 1921, 1922, 1923, 1924, 1925.

IF YOU HAVE A CROP MORTGAGE-THAT TOBACCO DOES NOT HAVE TO GO TO THE ASSOCIATION

3. The grower expressly warrants that he has not heretofore contracted to sell, market, or delirer, any of the said tobacco to any person, firm, or corporation, except as noted at the end of this agreement. Any tobacco corered by such existing contracts or crop mortgage shall be exclucled from the terms hereof for the period and to the extent noted.

\section{THE ASSOCIATION TELLS YOU WHERE TO DELIVER}

4. (a) All tobacco shall be delivered at the earliest reasonable time after picking or curing, to the order of the assocation, at the warehouse or plant controlled or specified by the association; or at the nearest warehouse, if the association controls or specifies no warehouse, or plant in that immediate district; or by shipment, as directed, to the association and by delivery to the association of the indorsed warehouse or other receipts or bills of lading properly directed.

\section{POOR TOBACCO IS PENALTZED}

(b) Any deduction or allowance or loss that the association may make or suffer on account of inferior grade, quality, or condition at delivery, shall be charged against the grower individually. 


\section{ASSOCLATION WILL TRY TO STANDARDIZE METHODS}

(c) The association shall make rules and regulations and shall provide inspectors or graders to standardize and grade the quality and the method and manner of handling, curing, and shipping such tobacco; and the grower agrees to observe and perform any such rules and regulations and to adopt the grading established by the State and Federal authorities and the association.

\section{ALL TOBACCO WILL BE POOLED FOR EACH YEAR BY TYPE AND GRADE}

5. The association shall pool or mingle the tobacco of the grower with tobacco of a like type, grade, and quality delivered in the same crop year by other growers. The association shall classify the tobacco and its class fication shall be conclusive.

The tobacco delivered in any crop year to any point at the order of the association, shall be handled in one major pool; and the minor pools shall be by type and grade.

ASSOCIATION WILL RESELL ALL TOBACCO AND PAY NET PROCEEDS TO GROWER-COSTS OF OPERATION AND ONERHEAD WILL BE DEDUCTED, BUT THE ASSOCIATION IS FORBIDDEN TO MAKE ANY PROFIT FOR ITSELF

6. The association agrees to resell such tobacco, together with tobacco of like, trpe, grade, and quality delivered by other growers under similar contracts, at the best prices obtainable by it under market conditions, and to pay orer the net amount received therefrom (less freight, insurance, and interest), as parment in full to the grower and growers named in contracts similar hereto, according to the tobacco delirered br each of them, after deducting therefrom, Within the discretion of the association, the costs of maintaining the association. and of handling, grading, and marketing such tobacco; and of reserves for credits and other general commercial purposes (saic reserves not to exceed 1 per cent of the gross resale price). The annual surplus from such deductions must be prorated among the growers clelivering tobacco in that zear on the basis of deliveries.

EVERY GROWER GETS TEE SAME AMOUNT FOR THE SAME TYPE, QUALITY, AND QUANTITY OF TOBACCO

7. The gromer agrees that the association may handle, in its discretion. some of the tobacco in one way and some in another; mar sell some upon delirery; mas cure or process or manufacture all or any portion thereof; but the net proceeds of all tobacco or tobaceo products of like tyne, quality. and grade less charges, costs, and advances, shall be divided ratably among the growers in proportion to their delireries to each pool, payments to be made from time to time until all the accounts of each pool are settled.

The association may contract with the owners of redrying plants to redry and store the tobacco delivered by the members of the association.

THE TOBACCO WILL BE SOLD ANYWHERE-FOR EXPORT OR OTHERWISE, WHERE IT WILL BE MOST PROFITABLE

8. The association may sell the said tobacco within or without the United States, directly to manufacturers or exporters, or otherwise at such time and in such form upon such conditions and terms as it may deem profitable, fair, and adrantageous to the growers; and it may sell all or any part of the tobacco with or through any other agency hereafter established, for the cooperatire marketing of the tobacco of growers in other States throughout the United States, under such conditions as will serve the joint interest of the growers and the publiç; and any proportionate expenses connected therewith shall be deemed marketing costs under paragraph 6 .

\section{THE ASSOCIATION CAN RAISE MONEY TO MAKE FIRST PAYMENT TO GROWERS}

9. The grower agrees that the association shall borrow money in its name on the tobacco, through drafts, acceptances, notes, or otherwise, or on any warehouse receipts or bills of lading or upon any accounts for the sale of 
tobacco or on any commercial paper delivered therefor. The association shall prorate the money so receired among the growers equitably, as it may determine, for each district and period of delivery.

OFFICES OB PLANTS WHEREVER THEY ARE NEEDED

10. The association may establish selling offices, warehouses, plants, marketing, statistical, or other agencies in any place.

\section{YOU CAN STOP GROWING TOBACCO IF YOU WISH}

11. The grower shall have the right to stop growing tobacco and to grow anything else at any time at his free discretion; but if he produces any tobacco or acquires or owns any interest in any tubacco, as landlord or lessor, during the term hereof it shall all be incluled under the terms of this agreement and must be sold only to the association.

\section{YOU DO NOT HAVE TO DELIVER ANY PARTICULAR AMOUNT}

12. Nothing in this agreement shall be interpreted as compelling the grower to delirer ans specified quantity of tobacco each sear; but he shall deliver all the tobacco produced by or for him.

\section{YOU DELIVER ALL THE TOBACCO YOU RAISE}

13. (a) This agreement shall be binding upon the grower as long as he produces tobacco directls or intirectly, or has the legal right to exercise control of any commercial tobacco or any interest therein as a producer or landlord during the terms of this contract.

(b) If this agreement is signed by the members of a copartnership it shall apply to them and each of them indiridually in the event of the dissolution or determination of the said copartnership.

YOU MAY MAKE A CROP MOBTGAGE-THE ASSOCIATION WILL TRY TO HELP YOU SECURE STANDARD TERMS

(c) If the grower places a crop mortage upon any of his crops during the term hereof, the association shall have the right to take delivery of his tobacco and to pay off all or part of the crop mortgage for the account of the grower and to charge the same against him individually.

The grower shall motify the association prior to making any crop mortgage, and the association will assist the grower in ans such transaction as far as it deems proper.

\section{STATISTICS ARE NEEDED}

14. From time to time the gromer agrees to mail to the association any statistical data requested, on the forms provided for that purpose by the association.

\section{ALL CONTRACTS ARE ALIKE}

15. This agreement is one of a series generally similar in terms, comprising with all such agreements, signed by individual growers, or otherwise, one single contract between the association and the said growers, annually and individually obligated under all of the terms thereof. The association shall be deemed to be acting in its own name, for all such growers, in any action or legal proceedings on or arising out of this contract.

THE GROWER AUTHORIZES THE ASSOCIATION TO BUILD CURING OR BEDRYING PLANTA IF IT NEEDS THEM

16. (a) The grower hereby expressly authorizes the association to deliver to any warehousing or other corporation organized for cooperation with this association, any or all of his tobacco for handling, processing, or manufacturing, or storing; and to charge against his tobacco and his prorated share of the 
funds necessary to create a reserve, equiralent to one class of its preferred stock annually, plus bonus, to retire the said class; and to pay the dividends on all outstanding stock thereof.

(b) The grower shill be charged for such derluctions only on account of warehouses or plants within his district, or within his benefit, as determined by the association; and for such deductions the grower shall receive a proportionate interest in such corporations.

\section{ANY OLD CROP TOBACCO MAY BE DELIVERED TO THE ASSOCIATION TO SELL}

17. If the grower has on hand on July 1. 1921, or July 1, 1922, if the organization is deferred, any tobacco of the 1920 or ans crops, free of liens and capable of delivery, he shall deliver su h tohacen to the assocation as it may direct, to be graded by the association and marketed by it in pools wholly separate from all other delireries hereunder, but generally in the manner here set forth.

\section{DO NOT BREAK THE CONTRACT-THIS IS EXPENSIVE}

18. (a) Inasmuch as the remedy at law would he inadequate, and inasmuch as it is now and erer will be impracticable and extremely difficult to determine the actual damage resulting to the association. should the grower fail so to sell and delirer all of his tobacco, the grower hereby agrees to pay to the association for all tobacco delivered, consinned, or marketed or withheld by or for him, other than in accordance with the terms hereof, the sum of 5 cents per pound, as liquidated damages areraged for all types and grades of tobacco for the breach of this contract. all parties agreeing that this contract is one of a series dependent for is true raine upon the adherence of each and all of the growers to each and all of the said contracts.

\section{WE WILL GET HIS TOBACCO ANYIVAY}

(b) The grower agrees that in the erent of a breach or threatened breach by him of any prorision regarding delirery of tobacco the association shall be entitled to an injunction to prerent further breach thereof and to a decree for specified performance hereof; and the parties agree that this is a contract for the purchase and sale of personal property under special circumstances and conditions and that the buyer can not go to the open markets and buy tobacco and replace any which the grower may fail to deliver.

\section{VIOLATORS PAY THE COSTS OF FIGHTING THEAT}

(c) If the association brings any action whatsoerer, by reason of a breach or threatened breach hereof, the grower agrees to pay to the association all costs of court, costs for bonds and otherwise, expenses of travel, and all expenses arising out of or caused by the litigation and any reasonable attorner's fee expended or incurred by it in such procedings: and all such costs and expenses shall be included in the judgment and shall be entitled to the benefit of any lien securing any judgment hereunder.

\section{THE CONTPACT IS COMIPLETE ON ITS FACE}

19. The parties agree that there are no oral or other conditions, promises, covenants, representations, or inducements in addition to or at viriance with any of the terms hereof; and that this agreement represents the roluntary and clear understanding of both parties fully and completely.

Read, considered, and signed by the grower, as of the date determined by the association contract in the State hereinbelow indicated.

\section{(End of marketing agreement)}

\section{MINOR CHANGES MAY BE MADE}

20. These provisions are subject to minor modification or amendment by the organization committee, on the suggestion of State officials or otherwise, so as to carry out the general purposes hereof. 


\section{ALI CONTRACTS ARE THE SAME-THERE ARE NO FAVORITES}

21. It is expressly agreed that this instrument is one of a series substantially identical in terms. All such instruments shall be deemed one contract tor the nurpose of binding the subscribers to the same extent als if all of the subscribers had signed one such contract.

Read, considered, and signed at day of 1922. this

(Do not sign without reading)

Grower

Post-office address.

County

Production in 1920 was

pounds of

type; acres

MODIFIED ORDER FOR RECEIVERS

IN THE DISTRICT COTTT OF THE UNITED STATES FOR THE EASTERN DISTRICT OF NORTH CAROLINA-IN EQUTTY

I. B. Farmer, C. F. Lorelace, J. E. Gosney, J. H. Butcher, and J. F. Williams et al. $v$. Tobacco Growers' Cooperative Association

ORDER APPOINTING RECEIVER

This cause coming on to be heard before the Hon. Isaac MI. Meekins, judge of the United States District Court for the Eastern District of North Carolina, and being heard on the 29th day of March, 1926, upon the bill filed in this cause, at which hearing both plaintiffs and defendant were present in person, and by attorneys, and after both sides had offererl evidence of their respective contentions, the court, on the $2 d$ day of April, 1926, denied the motion for the appointment of a receiver with leare to the plaintiffs to renew such motion upon giving the requisite notice and with the further stipulation of counsel that the evidence introduced at said hearing should be considered as offered in any subsequent hearing that might be had, and the plaintiffs haring renewed said motion for the appointment of a receirer and after giring due notice of such motion, this cause came on again to be heard in the city of Raleigh on the 1st day of June, 1926, and after hearing additional eridence offered by both plaintiffs and defendant.

It appearing to the court that, in riew of the past numerous breaches of contract by members of the association and recent demoralization among its members, the association can not reasonably expect to receire from its members under their delivery contracts a sufficient quantity of the 19:26 tobacco to justify incurring the expense of setting up a receiring system or to enable it to market its receipts with reasonably satisfactory results, and it further appearing that the orderly sale of the association tobacco and assets and the orcierly liquidation of its affairs are necessary and ineritable, and it further appearing that there are outstanding numerous unsecured obligations of the association which will become due in the immediate future and from time to time and that the sale of tobacco under pressure by the association to raise money to meet these obligations as they mature on the sale of association tobacco or association equity in tobacen by creditors under a jurgment would entail a substantial reduction in the price to be reasomably expected from such tobacco and great loss to the association and the members therenf and that the liquidation of the affairs of the association and the further conduct of the affairs of the association can be conducted most economicall $s$, most safely and for the best interest of the association, its members, and its creditors by a receirer or receivers under the supervision and orders of this court, and it further appearing that there hare from time to time been made against certain of the officers and directors of the association charges of misconduct or mismanagement and that it is for the best interest of the association. its members, the public, and for the general permanent future good of cooperative marketing that these charges be investigated by persons appointed by the court and that such impartial persons appointed by the court be in position to report back that such charges are unfounded or to request permission from the court to take appropriate action: 
It is now, therefore, upon all of the evidence introduced in this case and in addition thereto as an exercise of its sound discretion the court is of the opinion, and so holds, that receirers should be appointed by this court to administer the affairs of said association under the orders and directions of this court. It is thereupon, on motion of E. P. Buford, W. M. Person. P. W. Glidemeil, and Jones \& Hurton, attorners for the plaintiffs. ordered, adjudged, and decreed that James H. Pou, of Raleigh, N. C., and M. L. Corey, of New Iork. N. I.. and H. S. Ward. of Washington. N. C.. be, and they are hereby, constituted and appointed receivers to take charge of and administer all and sereral of the aftairs of the defendant, Tobacco Growers' Cooperative Association, with full pumer and authority ordinarils rested in receirers in like cases, and subject to the orders and directions of this court.

It is furtler ordered. adjudged. and decreed that before entering upon their duties as such receirers ther shall each gire a good and sufficient bond con. ditioned as required by lat in the sum of $\$ 50.000$, said bond to be approved by the clerk of this court.

It is further ordered. adjudged. and decreed that upon the execution of said bond ail the records and properties of said defendant assuciation be delirered to said receirers in such manner and at such times as said receirers may requ re.

It is further ordered. adjudged, and decreed that said receirers shall immediatels upon their qualification inrestigate the affairs of said association and particularly the cinar-es a rainst the management set out in the bill of complaint, and shall report the result of the $r$ inrestigation to this cuurt as earis as is conrenient fur them to do so, and said receirers shall hare full authority and power to employ accountants and clerical and legal assistants as may be necessary, in their discretion, to make such investigation.

It is further urdered, adjudged, and decreed that offeials and emplorees of said defentunt assmiation he, and they are lerebr. restrained from disposing of ans of the assets of said association or transacting further business except as directed $1: 5$ said receirers. ar under urier's of this court, and that the creditors of aid associating be and thes are herehr. restrained from in any wise interfering with said receirers, and from disposing of ant securities or equities of said assuciation, escept after applring for and obtaining an order of this court.

It is further ordered. adjudged. and decreed that a certified copy of the bill filed herein and this order of appointment he filed and entered in the district court for each district of this circuit in which ans portion of the property of the defendant asscicia-ion mas lie. or be in accorciance with Enited States Compiled Statutes. 1915. section 103s (Judicial Code, sec. 56).

And this cause is retained for further order.

Done this 19th day of June, 1926.

I. M. MEERTINS,

Cnited States District Judge.

To the foregoing order the defendants, and each of them. except and give notice of appeal to the Circuit Court of the Fourth Circuit. Further notice waired and appeal bond fired at $\$ 1,000$. June 19, 1926.

I. M. MEEKIYS, U. S. D. J. 


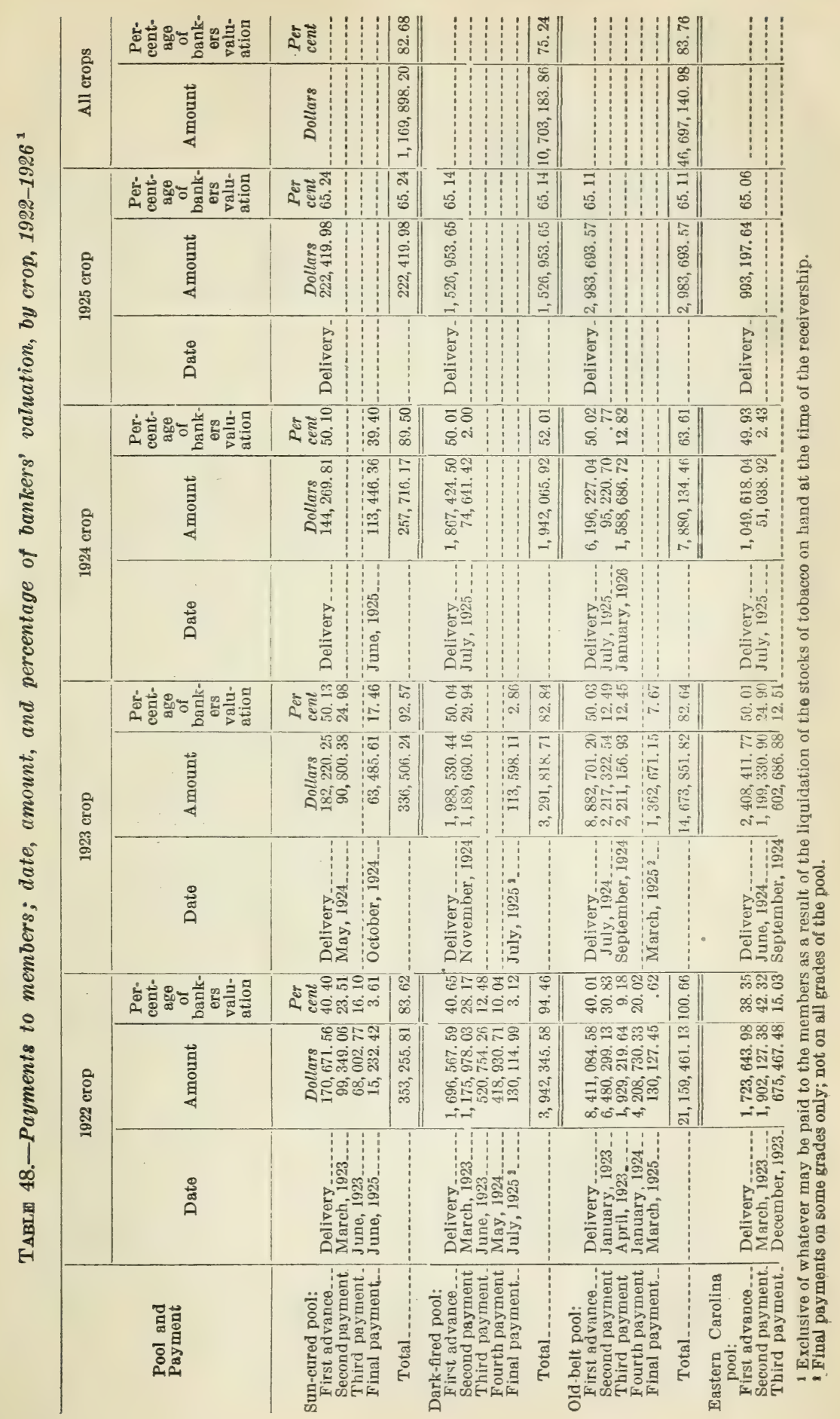


140 CiRCULAR 100 , U. S. DEPARTMENT OF AGRICULTURE

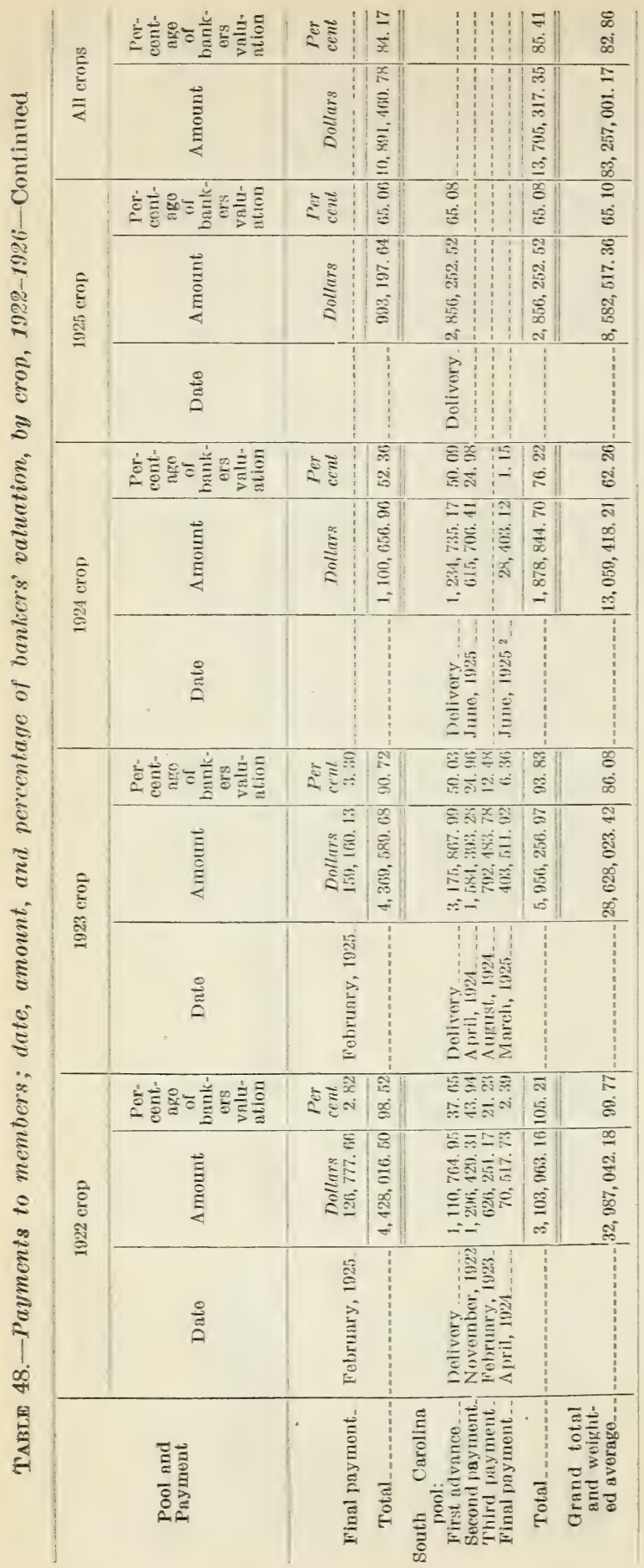


TABLE 49.-General overhead (head office) expenses to May 31, 1926, a located to the four crops

\begin{tabular}{|c|c|c|c|c|}
\hline Item & 1922 crop & 1923 crop & $1924 \mathrm{crop}$ & 1925 crop \\
\hline $\begin{array}{l}\text { Salaries } \\
\text { Traveling expense } \\
\text { Selling expense. } \\
\text { Auditing } \\
\text { A ppraising tobacco } \\
\text { Directors' fees and expenses. }\end{array}$ & \begin{tabular}{r|} 
Dollars \\
$638,789.23$ \\
$40,648.80$ \\
$18,546.91$ \\
13, i53. 83 \\
$12,480.00$ \\
$11,745.94$ \\
\end{tabular} & \begin{tabular}{r|} 
Dollars \\
$655,201.31$ \\
$31,829.77$ \\
49.286 .94 \\
$14,634.44$ \\
$1,680.00$ \\
$11,999.66$ \\
\end{tabular} & \begin{tabular}{r}
\multicolumn{1}{c}{ Dollars } \\
$807,863.46$ \\
$25,107.92$ \\
$14,612.56$ \\
$15,891.68$ \\
$1,680.00$ \\
$9,903.70$
\end{tabular} & $\begin{array}{r}\text { Dollars } \\
509,842.89 \\
20,992.98 \\
1,573.33 \\
2,256.62 \\
12,315.70\end{array}$ \\
\hline $\begin{array}{l}\text { Legal expenses: } \\
\text { Paid } \\
\text { Liquidated damages collected... }\end{array}$ & $\begin{array}{l}85,744.94 \\
46,401.80\end{array}$ & $\begin{array}{r}138,928.35 \\
38,904.00\end{array}$ & $\begin{array}{l}89,890.42 \\
62,538.85\end{array}$ & $\begin{array}{l}53,298.43 \\
17,165.68\end{array}$ \\
\hline $\begin{array}{l}\text { Ret legal expenses. } \\
\text { Insurance, general } \\
\text { Taxes } \\
\text { Heat, light, and water. } \\
\text { Office supplies and expenses. } \\
\text { Stationery and printing } \\
\text { Telephone, telegraph, and postage } \\
\text { Freight, drayage, and express } \\
\text { Automobile operating cost } \\
\text { Loss through bank failures }\end{array}$ & $\begin{array}{r}39,343.14 \\
18,590.00 \\
5,013.16 \\
15.00 \\
62.55 \\
18,123.11 \\
47,423.43 \\
12,140.20 \\
309.62 \\
4,743.41 \\
\end{array}$ & $\begin{array}{r}100,024.35 \\
18,996.67 \\
18,984.28 \\
13,031.21 \\
226.48 \\
22,919.84 \\
32,921.92 \\
11,541.54 \\
4,767.92 \\
12,224.27 \\
7,237.10\end{array}$ & $\begin{array}{r}27,351.57 \\
19,455.05 \\
19,414.19 \\
3,321.82 \\
28.81 \\
12,135.00 \\
18,758.31 \\
8,117.58 \\
9,212.79 \\
17,076.49 \\
428.17\end{array}$ & $\begin{array}{r}36,132.75 \\
15,440.00 \\
7,961.55 \\
2,160.71 \\
81.88 \\
10,668.80 \\
18,998.99 \\
9,602.45 \\
1,711.30 \\
732.78\end{array}$ \\
\hline $\begin{array}{l}\text { Loss new bean warehouse, fire } \\
\text { Organization expense } \\
\text { Furniture and fixtures } \\
\text { Depreciation, automobile } \\
\text { Loss on sales of automobiles. } \\
\text { Loss on sales of furniture and fixtures. }\end{array}$ & $\begin{array}{r}112.50 \\
30,462.78 \\
3,097.52 \\
3,413.00 \\
2,354.22\end{array}$ & $\begin{array}{r}27,030.87 \\
5,668.70 \\
9,238.46 \\
6,513.08\end{array}$ & $\begin{array}{r}25,058.32 \\
6,656.46 \\
13,570.67 \\
5,582.18 \\
\end{array}$ & $\begin{array}{r}26,814.17 \\
7,080.21 \\
14,795.72 \\
10,770.89 \\
1,749.39\end{array}$ \\
\hline Total_ & $921,098.35$ & $1,055,958.81$ & $1,061,226.73$ & $711,683.11$ \\
\hline Transferred to redrying expense. & $2,132.63$ & & $94,535.00$ & $81,064.59$ \\
\hline $\mathrm{Tc}$ & $918,965.72$ & $1,055,958.81$ & $966,691.73$ & $630,618.52$ \\
\hline
\end{tabular}

TABLE 50.-Carrying charges to May 31, 1926, distributed to crops and pools

\begin{tabular}{|c|c|c|c|c|c|c|}
\hline Crop and charge & $\begin{array}{c}\text { Sun-cured } \\
\text { pool }\end{array}$ & $\begin{array}{c}\text { Dark-fired } \\
\text { pool }\end{array}$ & $\begin{array}{l}\text { Old-belt } \\
\text { pool }\end{array}$ & $\underset{\text { parolina }}{\text { East }}$ & $\begin{array}{l}\text { South } \\
\text { Carolina } \\
\text { pool }\end{array}$ & All pools \\
\hline $\begin{array}{l}1922 \text { crop: } \\
\text { Interest, net } \\
\text { Insurance } \\
\text { Joint agents' commissions...... }\end{array}$ & $\begin{array}{l}\text { Dollars } \\
3,603.18 \\
998.35 \\
369.73\end{array}$ & $\begin{array}{l}\text { Dollars } \\
40,695.45 \\
10,902.17 \\
3,936.06\end{array}$ & \begin{tabular}{|c|} 
Dollars \\
$195,110.55$ \\
$50,312.05$ \\
$19,780.83$
\end{tabular} & $\begin{array}{c}\text { Dollars } \\
46,009.15 \\
11,113.03 \\
4,481.30\end{array}$ & $\begin{array}{r}\text { Dollars } \\
21,341.86 \\
5,032.38 \\
1,987.65\end{array}$ & $\begin{array}{l}\text { Dollars } \\
306,760.19 \\
78,357.98 \\
30,555.57\end{array}$ \\
\hline Total. & $4,971.26$ & $55,533.68$ & $265,203.43$ & $61,603.48$ & $28,361.89$ & $415,673.74$ \\
\hline $\begin{array}{l}1923 \text { crop: } \\
\text { Interest, net. } \\
\text { Insurance } \\
\text { Joint agents' commissions...... }\end{array}$ & $\begin{array}{r}4,490.04 \\
666.78 \\
260.92\end{array}$ & $\begin{array}{r}163,357.09 \\
18,434.88 \\
3,004.91\end{array}$ & $\begin{array}{r}445,641.51 \\
52,158.54 \\
12,596.49\end{array}$ & $\begin{array}{r}116,267.85 \\
13,851.55 \\
3,755.09 \\
\end{array}$ & $\begin{array}{r}153,442.09 \\
18,28 y .40 \\
4,973.18 \\
\end{array}$ & $\begin{array}{r}883,198.58 \\
103,401.15 \\
24,590.59 \\
\end{array}$ \\
\hline Total. & $5,417.74$ & $184,796.88$ & $510,396.54$ & $133,874.49$ & $176,704.67$ & $1,011,190.32$ \\
\hline $\begin{array}{l}1924 \text { crop: } \\
\text { Interest, net } \\
\text { Insurance } \\
\text { Joint agents' commissions..- }\end{array}$ & $\begin{array}{r}295.95 \\
19.30 \\
19.14\end{array}$ & $\begin{array}{r}113,988.29 \\
13,12.82 \\
2,976.27\end{array}$ & $\begin{array}{r}308,909.77 \\
33,400.90 \\
9,729.61\end{array}$ & $\begin{array}{r}48,289.30 \\
4,966.50 \\
1,722.54\end{array}$ & $\begin{array}{r}47,444.87 \\
4,409.56 \\
2,054.73\end{array}$ & $\begin{array}{r}518,928.18 \\
55,923.08 \\
16,502.29\end{array}$ \\
\hline Total & 334.39 & $130,091.38$ & $352,040.28$ & $54,978.34$ & $53,909.16$ & $591,353.55$ \\
\hline $\begin{array}{l}1925 \text { crop: } \\
\text { Interest, net... } \\
\text { Insurance } \\
\text { Joint agents' commissions.... } \\
\text { Federal intermediate credit } \\
\text { bank }\end{array}$ & $\begin{array}{r}640.91 \\
58.47 \\
20.50 \\
14.25\end{array}$ & $\begin{array}{r}14,510.16 \\
1,431.01 \\
501.83 \\
348.91\end{array}$ & $\begin{array}{r}63,966.52 \\
6,466.49 \\
2,267.68 \\
1,576.66 \\
\end{array}$ & $\begin{array}{r}20,567.44 \\
2,152.23 \\
754.74 \\
524.76\end{array}$ & $\begin{array}{r}64,758.61 \\
7,001.36 \\
2,455.25 \\
1,707.07\end{array}$ & $\begin{array}{r}164,443.64 \\
17,109.56 \\
6,000.00 \\
4,171.65\end{array}$ \\
\hline Total & 734.14 & $16,791.91$ & $74,277.35$ & $23,999.17$ & $75,922.29$ & $191,724.85$ \\
\hline
\end{tabular}


TABLs 51.-Redrying expenses to May 31, 1926, distributed to crops and pools

\begin{tabular}{|c|c|c|c|c|c|c|}
\hline Crop and charge & $\begin{array}{l}\text { Sun- } \\
\text { cured } \\
\text { pool }\end{array}$ & $\begin{array}{l}\text { Dark- } \\
\text { fired pool }\end{array}$ & $\begin{array}{l}\text { Old belt } \\
\text { pool }\end{array}$ & $\begin{array}{c}\text { Eastern } \\
\text { Carolina } \\
\text { pool }\end{array}$ & $\begin{array}{l}\text { South } \\
\text { Carolina } \\
\text { pool }\end{array}$ & All pools \\
\hline 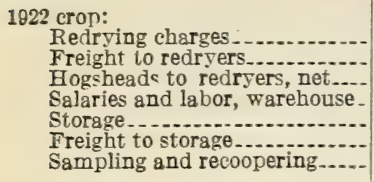 & $\begin{array}{r}\text { Dollars } \\
22,499.16 \\
3,916.66 \\
2,319.48 \\
4,946.91 \\
3,564.42 \\
186.33 \\
695.53\end{array}$ & \begin{tabular}{|c|} 
Dollars \\
$106,329.70$ \\
12.549 .96 \\
$17,295.91$ \\
$19,083.81$ \\
18.345 .04 \\
$6,852.74$ \\
$8,558.36$ \\
\end{tabular} & $\begin{array}{c}\text { Dollars } \\
386,803.13 \\
55,267.74 \\
72,333.56 \\
73.689 .65 \\
54.157 .72 \\
17.149 .82 \\
10,987.12 \\
\end{array}$ & $\begin{array}{c}\text { Dollarg } \\
162.583 .06 \\
18,485.13 \\
14.567 .73 \\
33,141.38 \\
58.894 .07 \\
25,919.27 \\
13.256 .89 \\
\end{array}$ & $\begin{array}{c}\text { Dollars } \\
161.327 .59 \\
28.954 .21 \\
37.226 .29 \\
30.759 .53 \\
18.590 .53 \\
29,258.10 \\
3,676.58 \\
\end{array}$ & \begin{tabular}{l}
\multicolumn{1}{c}{ Dollars } \\
$839,542.64$ \\
119.173 .70 \\
$143,742.97$ \\
$161,621.38$ \\
$153,551.78$ \\
$79,366.26$ \\
$37,174.48$
\end{tabular} \\
\hline Tot & $38,128.48$ & $189,015.52$ & $670,388.74$ & $326,847.53$ & $309,792.93$ & $1,534,173.21$ \\
\hline 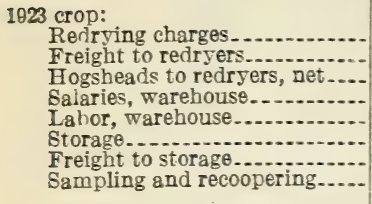 & $\begin{array}{r}4,988.07 \\
851.42 \\
939.52 \\
1,244.29 \\
1,880.52 \\
2,401.55 \\
34.89 \\
78.75 \\
\end{array}$ & $\begin{array}{r}239,055.06 \\
23,161.25 \\
19,078.52 \\
35,635.91 \\
15,065.78 \\
42,077.14 \\
24,735.34 \\
8,072.24 \\
\end{array}$ & $\begin{array}{r}848,056.16 \\
106,995.24 \\
68,24.36 \\
182,295.54 \\
56,967.79 \\
185,840.87 \\
102.212 .33 \\
41,368.79 \\
\end{array}$ & $\begin{array}{r}323,696.94 \\
30,710.26 \\
15,030.86 \\
62,118.42 \\
16.757 .64 \\
64,021.13 \\
74,740.84 \\
25,615.95 \\
\end{array}$ & $\begin{array}{r}390,019.05 \\
72,587.01 \\
31,159.52 \\
72,495.09 \\
21.503 .69 \\
58,927.37 \\
109,426.45 \\
23,792.31 \\
\end{array}$ & $\begin{array}{r}1,905,815.28 \\
234,305.18 \\
134,453.78 \\
353,789.24 \\
112,185.42 \\
353,268.06 \\
311,149.85 \\
88,928.04 \\
\end{array}$ \\
\hline Total & $12,419.00$ & $406,881.24$ & $1,691,982.08$ & $612,702.04$ & $779,910.49$ & 3,503 , \\
\hline 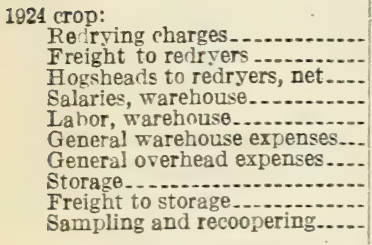 & $\begin{array}{r}646.57 \\
63.11 \\
52.85 \\
109.69 \\
14.91 \\
148.74 \\
51.99 \\
97.55 \\
6.75 \\
48.40 \\
\end{array}$ & $\begin{array}{r}370,741.57 \\
28,149.79 \\
13,367.04 \\
50,738.05 \\
6,874.06 \\
58,699.17 \\
20.768 .84 \\
34,291.67 \\
49,375.94 \\
8,292.04 \\
\end{array}$ & $\begin{array}{r}676.681 .78 \\
82,169.21 \\
47.084 .91 \\
164,698.29 \\
17,216.42 \\
147,464.03 \\
51,547.42 \\
139,718.17 \\
107,114.27 \\
38,670.54 \\
\end{array}$ & $\begin{array}{r}145,309.64 \\
14,408.25 \\
5,468.20 \\
69,747.14 \\
5,845.09 \\
29,143.78 \\
10,187.47 \\
22.744 .94 \\
33,483.41 \\
13,777.46 \\
\end{array}$ & \begin{tabular}{|r|}
$174,099.74$ \\
$29,328.16$ \\
$14,209.60$ \\
47.507 .49 \\
$7,114.99$ \\
$34,984.81$ \\
12.229 .28 \\
$20,637.39$ \\
$48,987.89$ \\
12.583 .42 \\
\end{tabular} & $\begin{array}{r}1,367,479.30 \\
154,118.52 \\
80,182.60 \\
332.800 .66 \\
37,065.47 \\
270,440.53 \\
94,785.00 \\
217,489.72 \\
238,96826 \\
73,371.86\end{array}$ \\
\hline Total & $1,240.56$ & $641,298.17$ & $1,472,365.04$ & $350,115.38$ & $401,682.77$ & 92 \\
\hline $\begin{array}{l}25 \text { crop: } \\
\text { Redrying charges............. } \\
\text { Freight to redryers.......... } \\
\text { Hogsheads to redryers, net... } \\
\text { Salaries, warehouse.......... } \\
\text { Lahor, Warehouse............ } \\
\text { General warehouse expenses. } \\
\text { General overhead expenses.. } \\
\text { Storage. } \\
\text { Freight to storage................. } \\
\text { Sampling and recoopering... }\end{array}$ & $\begin{array}{r}919.49 \\
494.33 \\
312.50 \\
306.76 \\
34.21 \\
243.94 \\
132.32 \\
138.25 \\
11.05 \\
\end{array}$ & $\begin{array}{r}124,774.83 \\
14,060.43 \\
7,307.16 \\
16,220.75 \\
1,909.24 \\
13,163.77 \\
7,8.5 .88 \\
5,468.65 \\
19,201.08 \\
225.98 \\
\end{array}$ & $\begin{array}{r}263,510.43 \\
56,164.54 \\
29,361.17 \\
85,098.36 \\
9,401.74 \\
69,060.60 \\
36,706.70 \\
41.83090 \\
61,604.29 \\
4,418.76 \\
\end{array}$ & $\begin{array}{r}76,104.04 \\
18,186.56 \\
5,000.46 \\
17.312 .88 \\
1,931.05 \\
14.050 .07 \\
7,46.7 .81 \\
7.830 .95 \\
22.877 .74 \\
6,929.95 \\
\end{array}$ & $\begin{array}{r}227,093.43 \\
90,667.67 \\
32,165.67 \\
67,004.19 \\
7,473.54 \\
54.376 .48 \\
28.901 .88 \\
32,511.97 \\
78,352.14 \\
15,025.46 \\
\end{array}$ & $\begin{array}{r}692.402 .22 \\
180,473.53 \\
74,146.96 \\
185,942.94 \\
20,739.78 \\
150,899.86 \\
81,064.59 \\
87.780 .72 \\
182,035.25 \\
25,611.20 \\
\end{array}$ \\
\hline Tot & $2,597.85$ & $210,987.77$ & $657,247.49$ & $177,691.51$ & $633,572.43$ & $682,097.05$ \\
\hline
\end{tabular}




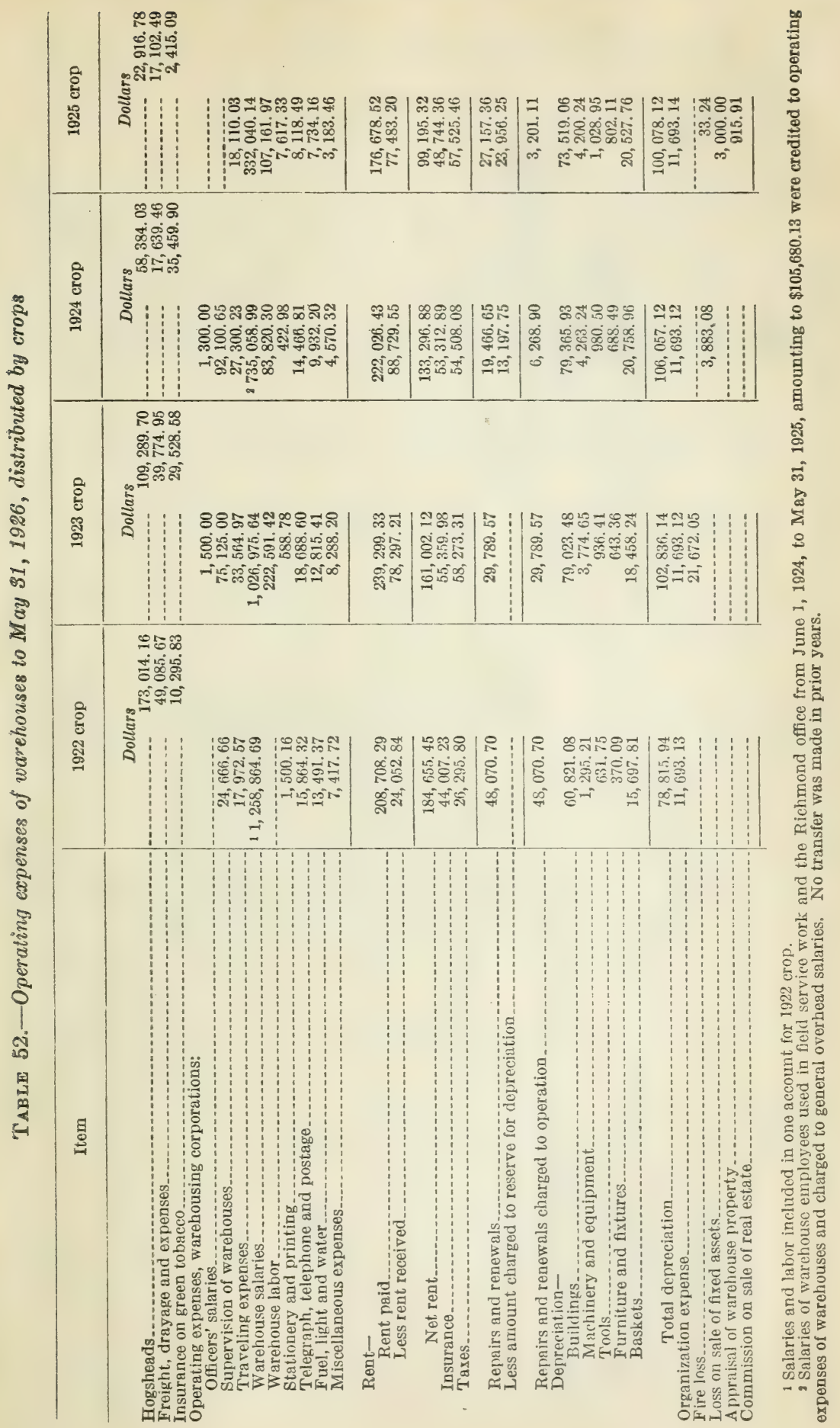


144 CIRCULAR 100, U. S. DEPARTMENT OF AGRICULTURE

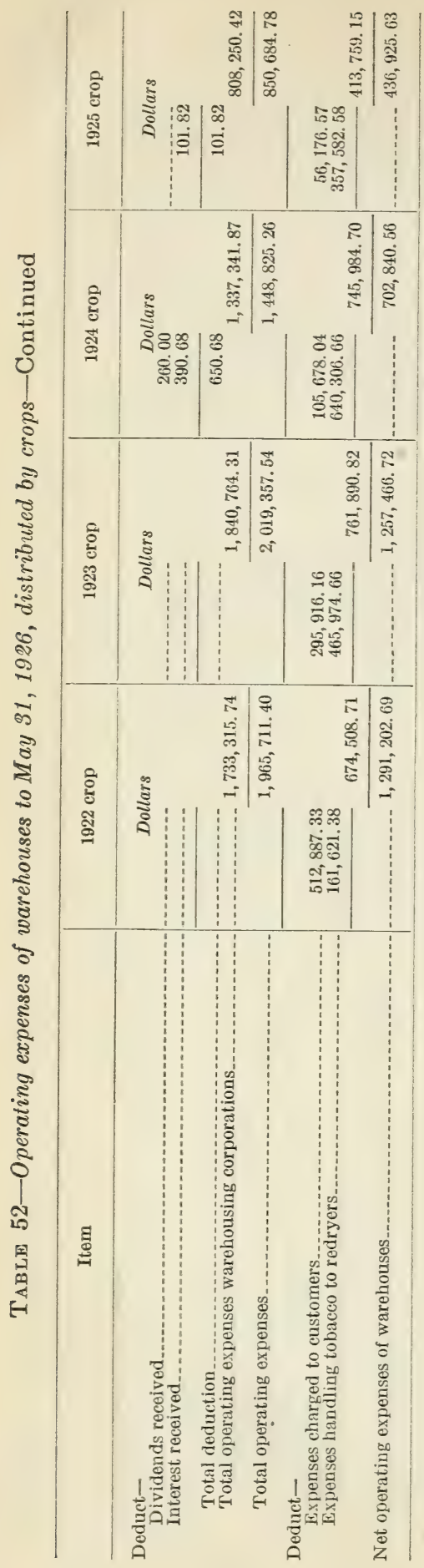


TABLE 53.-Expenses of operation of ficld service department to May 31, 1926, distributed to crops

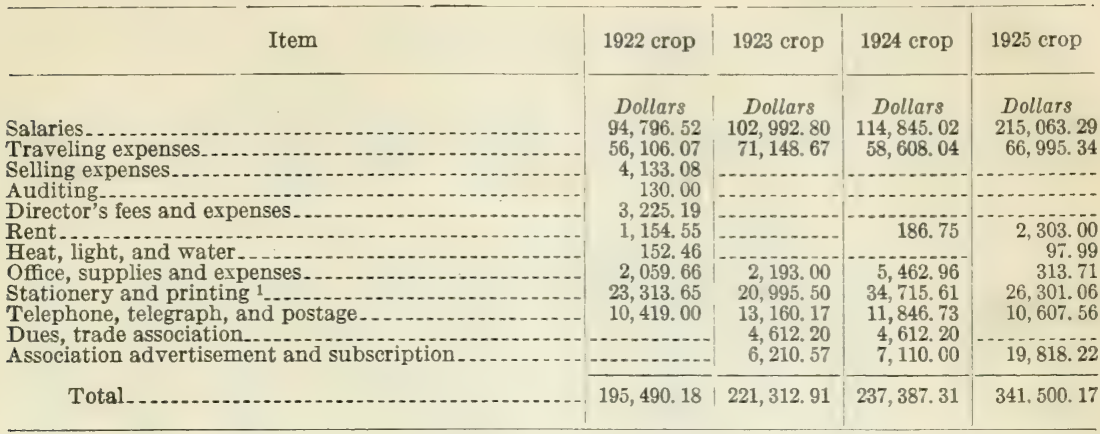

1 Receipts from advertising space sold in 1923,1924 , and 1925 amounted to $\$ 10,189.49, \$ 17,885.04$, and $\$ 13,720.53$ respectively, the total net operating costs for those years being thereby reduced to $\$ 211,123.42$, $\$ 219,502.27$, and $\$ 327,779.64$.

TABLE 54.-Estimated value of the tobacco received by the association, by crops and pools, on the basis of the bankers' valuations

\begin{tabular}{|c|c|c|c|c|c|c|c|}
\hline Crop and pool & $\begin{array}{l}\text { Total } \\
\text { received }\end{array}$ & $\begin{array}{l}\text { Bank- } \\
\text { ers' } \\
\text { valu- } \\
\text { ation } 1\end{array}$ & Total value & Crop and pool & $\begin{array}{c}\text { Total } \\
\text { received }\end{array}$ & $\begin{array}{l}\text { Bank- } \\
\text { ers' } \\
\text { valu- } \\
\text { ation } 1\end{array}$ & Total ralue \\
\hline \begin{tabular}{l}
\multicolumn{1}{c}{1922} \\
Sun-cured \\
Dark-fired....... \\
Old belt \\
EasternCarolina. \\
South Carolina.--
\end{tabular} & $\begin{array}{c}\text { Pounds } \\
3,580,093 \\
26,824,376 \\
89,925,280 \\
23,228,106 \\
20,032,214\end{array}$ & $\begin{array}{l}\text { Dollars } \\
11.80 \\
15.56 \\
23.38 \\
19.35 \\
14.73\end{array}$ & \begin{tabular}{r}
\multicolumn{1}{c}{ Dollars } \\
$422,502.86$ \\
$4,173,915.97$ \\
$21,022,362.14$ \\
$4,495,059.95$ \\
$2,950,280.30$
\end{tabular} & \begin{tabular}{l}
\multicolumn{1}{c}{1924} \\
Sun-cured........ \\
Dark-fired....... \\
Old belt. \\
Eastern Carolina. \\
South Carolina..-
\end{tabular} & \begin{tabular}{|c|} 
Pounds \\
$2,116,521$ \\
$20,226,469$ \\
$58,260,599$ \\
$9,446,515$ \\
$13,791,196$
\end{tabular} & \begin{tabular}{|l|} 
Dollars \\
13.60 \\
18.46 \\
21.26 \\
22.25 \\
17.87
\end{tabular} & $\begin{array}{r}\text { Dollars } \\
287,950.15 \\
3,733,788.44 \\
12,388,436.66 \\
2,101,995.12 \\
2,464,885.88\end{array}$ \\
\hline Total_ & $163,590,069$ & -..... & $33,064,121.22$ & Total & $103,841,300$ & & $20,977,056.25$ \\
\hline \begin{tabular}{l}
\multicolumn{1}{c}{1923} \\
Sun-cured.-...... \\
Dark-fired........ \\
Old belt \\
Eastern Carolina. \\
South Carolina..-
\end{tabular} & $\begin{array}{r}3,019,950 \\
24,149,287 \\
91,490,584 \\
26,945,141 \\
34,532,990\end{array}$ & $\begin{array}{l}12.04 \\
16.46 \\
19.41 \\
17.87 \\
18.38\end{array}$ & $\begin{array}{r}363,520.26 \\
3,974,099.76 \\
17,755,039.45 \\
4,815,986.70 \\
6,347,899.84\end{array}$ & \begin{tabular}{l}
\multicolumn{1}{c}{1925} \\
Sun-cured........ \\
Dark-fired........ \\
Old belt....... \\
Eastern Carolina. \\
South Carolina..
\end{tabular} & $\begin{array}{r}1,972,920 \\
14,506,240 \\
34,620,088 \\
6,965,169 \\
25,569,257\end{array}$ & $\begin{array}{l}17.28 \\
16.16 \\
13.24 \\
21.92 \\
17.16\end{array}$ & $\begin{array}{r}340,924.55 \\
2,344,051.56 \\
4,582,361.89 \\
1,526,550.15 \\
4,388,902.83\end{array}$ \\
\hline Tota & $180,137,952$ & & $33,256,546.01$ & Total & $83,633,674$ & & $13,182,790.98$ \\
\hline
\end{tabular}

1 Per 100 pounds.

ГABLE 55.-Comparison of quantity of tobacco in hands of association and sales by crop years

\begin{tabular}{|c|c|c|c|c|c|c|}
\hline Crop year 1 & $\begin{array}{c}\text { Receipts of } \\
\text { tobacco }\end{array}$ & $\begin{array}{c}\text { Stock at } \\
\text { beginning } \\
\text { of crop } \\
\text { year }\end{array}$ & $\begin{array}{l}\text { Receipts } \\
\text { plus stocks }\end{array}$ & $\begin{array}{l}\text { Stocks at } \\
\text { end of } \\
\text { crop year }\end{array}$ & Sales & $\begin{array}{l}\text { Percentage } \\
\text { of sales to } \\
\text { quantity } \\
\text { available }\end{array}$ \\
\hline $\begin{array}{l}1922-23 \\
1923-24 \\
1924-25 \\
1925-26\end{array}$ & $\begin{array}{c}1,000 \\
\text { pounds } \\
163,590 \\
180,138 \\
103,841 \\
83,634\end{array}$ & $\begin{array}{r}1,000 \\
\text { pounds } \\
0 \\
33,776 \\
78,725 \\
80,729\end{array}$ & $\begin{array}{c}1,000 \\
\text { pounds } \\
163,590 \\
213,914 \\
182,566 \\
164,363\end{array}$ & $\begin{array}{c}1,000 \\
\text { pounds } \\
33,776 \\
78,725 \\
80,729 \\
273,042\end{array}$ & $\begin{array}{c}1,000 \\
\text { pounds } \\
129,814 \\
135,189 \\
101,837 \\
91,321\end{array}$ & $\begin{array}{l}79.4 \\
63.2 \\
55.8 \\
55.6\end{array}$ \\
\hline Total . . & 531,203 & . & 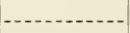 & 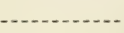 & 458,161 & 386.2 \\
\hline
\end{tabular}

1 Crop year June 1 to May 31.

2 Appendix Table 14 gives the tobacco inventory at the date of the receivership.

'Percentage total association sales were of receipts for the 4 years, to May $31,1926$. 
TABLE 56.-Comparison of the prices received by the association for green tobacco, redried tobacco, and the banker's valuation, per 100 pounds, by grades, green basis

[Eastern Carolina pool, 1923 crop]

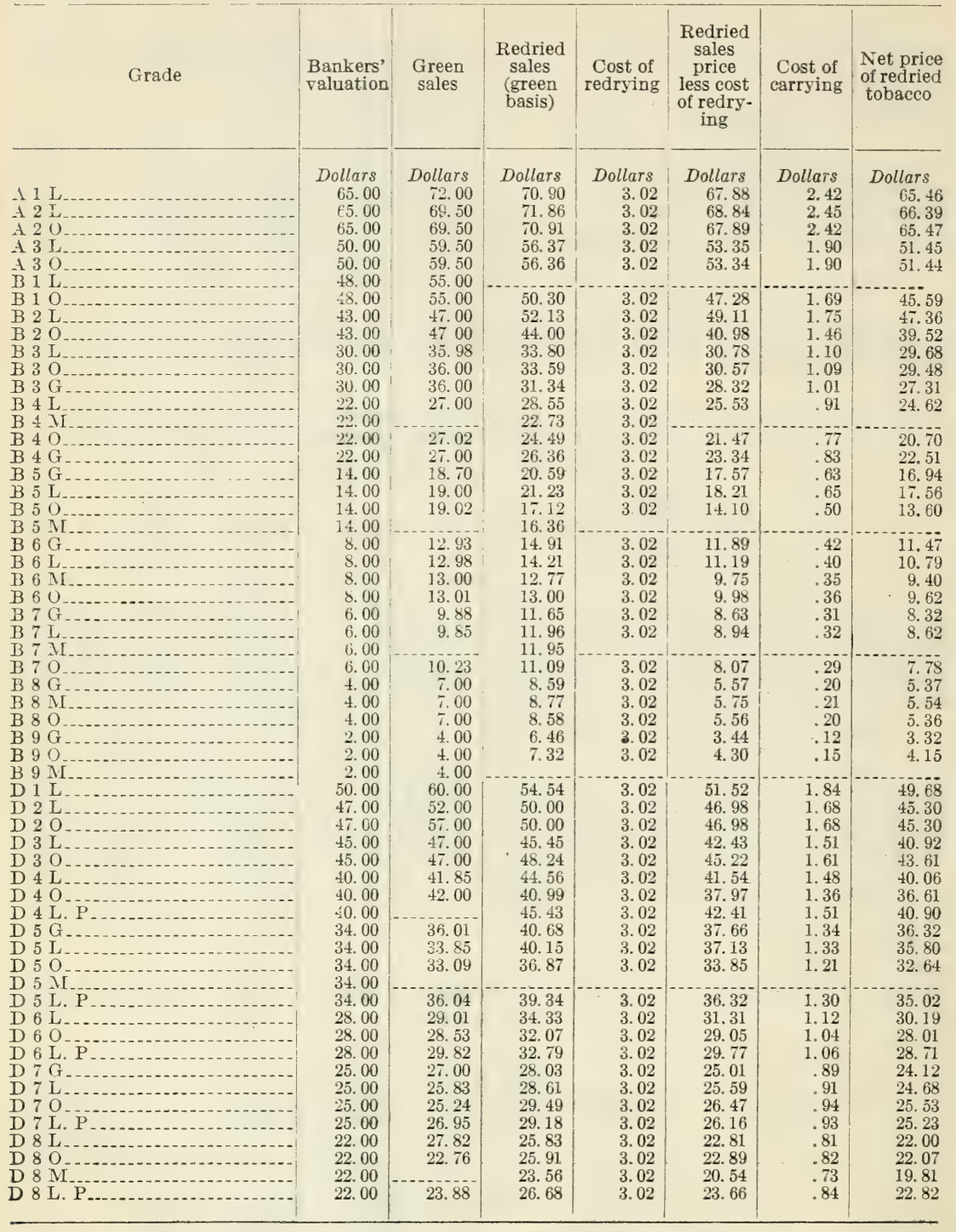


TABLE 57.-Comparison of the prices received by the association for green. tobacco, redried tobacco, and the bankers valuation, per 100 pounds, by grades, green basis

[South Carolina pool, 1923 crop]

\begin{tabular}{|c|c|c|c|c|c|c|c|}
\hline Grade & $\begin{array}{l}\text { Bankers' } \\
\text { valuation }\end{array}$ & $\begin{array}{l}\text { Green } \\
\text { sales }\end{array}$ & $\begin{array}{l}\text { Redried } \\
\text { sales } \\
\text { (green } \\
\text { basis) }\end{array}$ & $\begin{array}{l}\text { Cost of } \\
\text { redrying }\end{array}$ & $\begin{array}{l}\text { Redried } \\
\text { sales } \\
\text { price } \\
\text { less cost } \\
\text { of redry- } \\
\text { ing }\end{array}$ & $\begin{array}{l}\text { Cost of } \\
\text { carrying }\end{array}$ & $\begin{array}{c}\text { Net price } \\
\text { of redried } \\
\text { tobacco }\end{array}$ \\
\hline & Dollars & Dollars & Dollars & Dollars & Dollars & Dollars & Dollars \\
\hline A $2 \mathrm{~L}$ & 65.00 & 68.50 & 67.27 & 3.30 & 63.97 & 2.39 & 61.58 \\
\hline A $3 \mathrm{~L}$. & 50.00 & 58. 50 & 59.39 & 3. 30 & 56.09 & 2. 10 & 53. 99 \\
\hline non & 50.00 & 58. 50 & 61.52 & 3. 30 & 58. 22 & 2. 18 & 56.04 \\
\hline B 2 L & 43. 00 & 46. 00 & 47.12 & 3.30 & 43.82 & 1. 64 & 42.18 \\
\hline $\mathrm{B} 2 \mathrm{O}$ & 43. 00 & 46. 00 & 45.35 & 3. 30 & 42.05 & 1. 57 & 40.48 \\
\hline B $3 \mathrm{G} \ldots \ldots$ & 30.00 & 35.00 & 36. 36 & 3. 30 & 33.06 & 1. 24 & 31.82 \\
\hline B $3 \mathrm{~L}$ & 30.00 & 34.88 & 36. 69 & 3. 30 & 33.39 & 1. 25 & 32. 14 \\
\hline B 3 O & 30.00 & 32.29 & 37.99 & 3. 30 & 34. 69 & 1. 30 & 33. 39 \\
\hline B 4 G & 22.00 & 26. 00 & 27.28 & 3. 30 & 23.98 & .90 & 23. 08 \\
\hline B 4 L $\ldots \ldots$ & 22.00 & 25.87 & 27.49 & 3. 30 & 24. 19 & .90 & 23. 29 \\
\hline B 4 O & 22.00 & 24.80 & 25.49 & 3. 30 & 22.19 & .83 & 21. 36 \\
\hline B 5 G & 14.00 & 18. 00 & 19. 76 & 3. 30 & 16.46 & .62 & 15.81 \\
\hline B 5 L & 14.00 & 17.97 & 20.00 & 3. 30 & 16. 70 & .62 & 16. 08 \\
\hline B 5 O & 14. 00 & 17. 30 & 17.82 & 3. 30 & 14. 52 & .54 & 13. 98 \\
\hline B 6 G & 8.00 & 12.00 & 13.83 & 3. 30 & 10.53 & .39 & 10.14 \\
\hline B 6 B $6 \mathrm{M}$ & 8.00 & 12.00 & 14. 72 & 3.30 & 11.42 & .43 & 10.99 \\
\hline $\begin{array}{l}\text { В } 6 \mathrm{M} \\
\mathrm{B} 6 \mathrm{O}\end{array}$ & $\begin{array}{l}8.00 \\
8.00\end{array}$ & 12.00 & 12. 38 & $\begin{array}{l}3.30 \\
3.30\end{array}$ & 9.08 & .34 & 8.74 \\
\hline B $7 \mathrm{G}-$ & $\begin{array}{l}8.00 \\
6.00\end{array}$ & $\begin{array}{r}12.00 \\
9.00\end{array}$ & 11.92 & $\begin{array}{l}3.30 \\
3.30\end{array}$ & $\begin{array}{l}8.62 \\
8.02\end{array}$ & & 8. $3 \mathrm{C}$ \\
\hline B $7 \mathrm{~L} \ldots$ & 6.00 & 9.00 & 11.14 & 3. 30 & $\begin{array}{l}8.02 \\
7.84\end{array}$ & $\begin{array}{l}.30 \\
29\end{array}$ & $\begin{array}{l}7.72 \\
7.75\end{array}$ \\
\hline 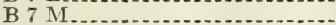 & 6.00 & 9.00 & 10.68 & 3. 30 & 7. 38 & .28 & $\begin{array}{l}7.55 \\
7.10\end{array}$ \\
\hline 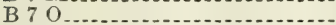 & 6.00 & 9.00 & 10. 78 & 3. 30 & 7.48 & .28 & 7.20 \\
\hline (2) & 4. 00 & 5.86 & 7.99 & 3.30 & 4. 69 & 18 & 4. 51 \\
\hline 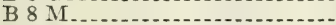 & 4. 00 & 6.00 & 7. 80 & 3. 30 & 4. 50 & 17 & 4. 33 \\
\hline B 80 & 4. 00 & 6.00 & 7. 98 & 3. 30 & 4. 68 & 18 & 4. 50 \\
\hline B 9 G & 2. 00 & 3. 00 & 5. 91 & 3. 30 & 2. 61 & 10 & 2.51 \\
\hline B 9 M & 2.00 & 3.00 & 5.91 & 3.30 & 2. 61 & 10 & 2. 51 \\
\hline B 9 O & 2.00 & 3. 00 & 6. 31 & 3. 30 & 3. 01 & .11 & 2.90 \\
\hline D $3 \mathrm{~L}$ & 45.00 & 47.50 & 48.92 & 3.30 & 45.62 & 1. 71 & 43.91 \\
\hline D $3 \mathrm{O}_{\ldots}$ & 45.00 & 47.50 & 45.88 & 3. 30 & 42.58 & 1. 59 & 40.99 \\
\hline 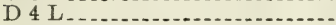 & 40.00 & 42.00 & 43. 74 & 3. 30 & 40.44 & 1. 51 & 38.93 \\
\hline D $5 \mathrm{G}_{2}$ & 34.00 & 36.00 & 37.32 & 3.30 & 34.02 & 1. 27 & 32. 75 \\
\hline D $5 \mathrm{~L}_{-}$ & 34.00 & 34.68 & 37.59 & 3. 30 & 34.29 & 1. 28 & 33.01 \\
\hline $\mathrm{D} 5 \mathrm{O} \ldots$ & 34.00 & 34.50 & 37.14 & 3. 30 & 33.84 & 1. 27 & 32.57 \\
\hline D $5 \mathrm{~L} . \mathrm{P}$ & 34.00 & 36.00 & 38.37 & 3.30 & 35.07 & 1. 31 & 33.76 \\
\hline $\mathrm{D} 6 \mathrm{~L}$ & 28. 00 & 29.50 & 31.82 & 3. 30 & 28.52 & 1.07 & 27.45 \\
\hline D 60 . & 28.00 & 29.45 & 31.57 & 3. 30 & 28.27 & 1. 06 & 27.21 \\
\hline D 6 L. P & 28.00 & 30.00 & 32. 19 & 3. 30 & 28.89 & 1. 08 & 27.81 \\
\hline D $7 \mathrm{G}$ & 25.00 & 27.00 & 29.56 & 3. 30 & 26.26 & .98 & 25.28 \\
\hline D $7 \mathrm{~L}$ & 25.00 & 26. 54 & 28. .2 & 3. 30 & 25.62 & .96 & 24. 66 \\
\hline D 7 L. P & 25.00 & 27.00 & 29.45 & 3. 30 & 26.15 & .98 & 25.17 \\
\hline$\ldots$ & 25.00 & 24.61 & 28. 78 & 3.30 & 25.48 & .95 & 24. 53 \\
\hline D $8 \mathrm{~L}$ & 22. 00 & 23. 60 & 25.56 & 3.30 & 22.26 & .83 & 21. 43 \\
\hline D $80 \ldots$ & 22.00 & 23. 76 & 25.34 & 3. 30 & 22.04 & .82 & 21. 22 \\
\hline D 8 L. P & 22.00 & 24.00 & 26. 37 & 3.30 & 23.07 & .86 & 22. 21 \\
\hline
\end{tabular}


TABLE 58.-Comparison of the prices received by the association for green tobacco, redried tobacco, and the bankers' valuation, per 100 pounds, by grades, green basis

[Old-belt pool, $1924 \mathrm{crop}]$

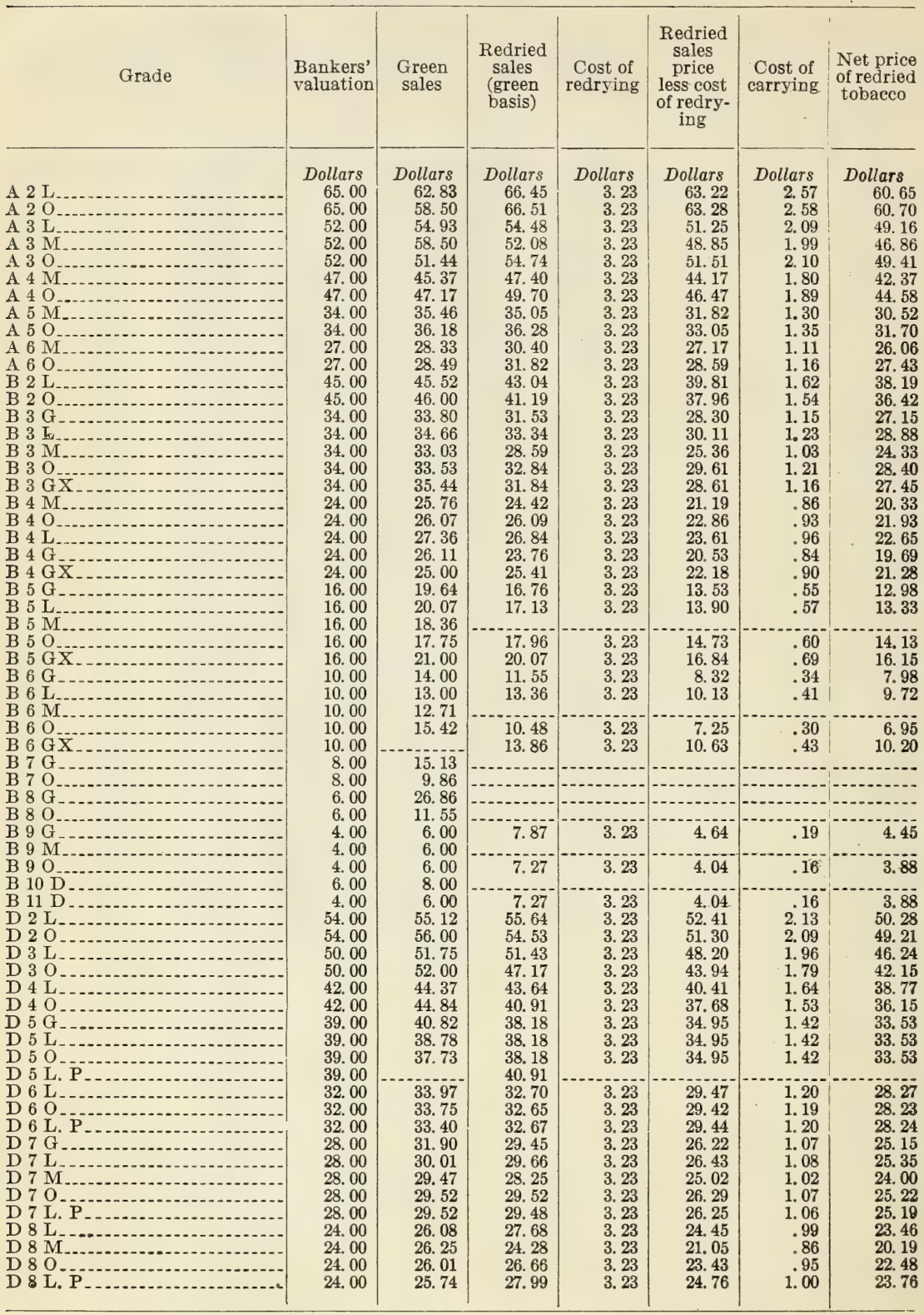


TABLE 59.-Comparison of the prices received by the association for green tobacco, redried tobacco, and the bankers' valuation, per 100 pounds, by grades, green basis

[Eastern Carolina pool, 1924 cropl

\begin{tabular}{|c|c|c|c|c|c|c|c|}
\hline Grade & $\begin{array}{l}\text { Bankers' } \\
\text { valuation }\end{array}$ & $\begin{array}{l}\text { Green } \\
\text { sales }\end{array}$ & $\begin{array}{l}\text { Redried } \\
\text { sales } \\
\text { (green } \\
\text { basis) }\end{array}$ & $\begin{array}{l}\text { Cost of } \\
\text { redrying }\end{array}$ & $\begin{array}{c}\text { Redried } \\
\text { sales } \\
\text { price } \\
\text { less cost } \\
\text { of redry- } \\
\text { ing }\end{array}$ & $\begin{array}{l}\text { Cost of } \\
\text { carrying }\end{array}$ & $\begin{array}{l}\text { Net price } \\
\text { of redried } \\
\text { tobacco }\end{array}$ \\
\hline 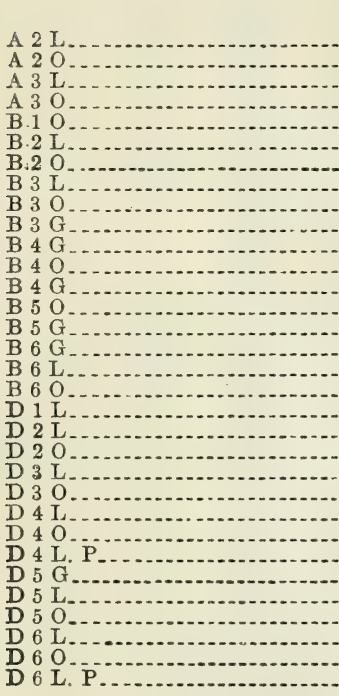 & $\begin{array}{r}\text { Dollars } \\
65.00 \\
65.00 \\
50.00 \\
50.00 \\
48.00 \\
43.00 \\
43.00 \\
32.00 \\
32.00 \\
32.00 \\
24.00 \\
24.00 \\
24.00 \\
16.00 \\
16.00 \\
10.00 \\
10.00 \\
10.00 \\
56.00 \\
52.00 \\
52.00 \\
48.00 \\
48.00 \\
40.00 \\
40.00 \\
40.00 \\
37.00 \\
37.00 \\
37.00 \\
32.00 \\
32.00 \\
32.00\end{array}$ & \begin{tabular}{r} 
Dollars \\
68.50 \\
68.50 \\
58.50 \\
58.50 \\
52.00 \\
46.00 \\
50.87 \\
31.62 \\
39.00 \\
\hdashline 25.90 \\
26.00 \\
26.00 \\
18.00 \\
13.00 \\
13.00 \\
13.00 \\
13.00 \\
65.00 \\
57.84 \\
56.00 \\
50.00 \\
50.00 \\
48.00 \\
$\cdots \cdots \cdots$ \\
39.00 \\
39.00 \\
39.00 \\
30.77 \\
27.96
\end{tabular} & $\begin{array}{l}\text { Dollars } \\
66.33 \\
65.90 \\
54.13 \\
52.72 \\
51.33 \\
51.52 \\
44.58 \\
35.78 \\
34.60 \\
33.64 \\
25.78 \\
25.43 \\
23.61 \\
1.24 \\
20.48 \\
16.05 \\
15.84 \\
12.75 \\
59.42 \\
57.71 \\
55.38 \\
50.62 \\
51.32 \\
44.17 \\
42.21 \\
45.45 \\
37.61 \\
38.16 \\
36.34 \\
33.72 \\
32.20 \\
33.54\end{array}$ & \begin{tabular}{r} 
Dollars \\
3.89 \\
3.89 \\
3.89 \\
3.89 \\
3.89 \\
3.89 \\
3.89 \\
3.89 \\
3.89 \\
3.89 \\
3.89 \\
3.89 \\
3.89 \\
3.89 \\
3.89 \\
3.89 \\
3.89 \\
3.89 \\
3.89 \\
3.89 \\
3.89 \\
3.89 \\
3.89 \\
3.89 \\
\hdashline..--- \\
3.89 \\
3.89 \\
3.89 \\
3.89 \\
3.89 \\
3.89
\end{tabular} & $\begin{array}{r}\text { Dollars } \\
62.44 \\
62.01 \\
50.24 \\
48.83 \\
47.44 \\
47.63 \\
40.69 \\
31.89 \\
30.71 \\
29.75 \\
21.89 \\
21.54 \\
19.72 \\
14.35 \\
16.59 \\
12.16 \\
11.95 \\
8.86 \\
55.53 \\
53.82 \\
51.49 \\
46.73 \\
47.43 \\
40.28 \\
38.32 \\
41.56 \\
33.72 \\
34.27 \\
32.45 \\
29.83 \\
28.31 \\
29.65\end{array}$ & $\begin{array}{r}\text { Dollars } \\
1.84 \\
1.82 \\
1.48 \\
1.44 \\
1.39 \\
1.40 \\
1.20 \\
.94 \\
.80 \\
.87 \\
.64 \\
.63 \\
.53 \\
.42 \\
.49 \\
.36 \\
.35 \\
.26 \\
1.63 \\
1.58 \\
1.51 \\
1.37 \\
1.39 \\
1.18 \\
1.13 \\
1.22 \\
.99 \\
1.00 \\
.95 \\
.88 \\
.83 \\
.87\end{array}$ & $\begin{array}{r}\text { Dollars } \\
60.60 \\
60.19 \\
48.76 \\
47.39 \\
46.05 \\
46.23 \\
39.49 \\
30.95 \\
29.81 \\
28.88 \\
21.25 \\
20.91 \\
19.14 \\
13.93 \\
16.10 \\
11.80 \\
11.60 \\
8.60 \\
53.90 \\
52.24 \\
49.98 \\
45.36 \\
46.04 \\
39.10 \\
37.19 \\
40.34 \\
32.73 \\
33.27 \\
31.50 \\
28.95 \\
27.48 \\
28.78\end{array}$ \\
\hline
\end{tabular}


TABLE 60.-Comparison of the prices received by the association for green tobacco, redried tobacco, and the bankers' valuation, per 100 pounds, by grades, green basis.

[South Carolina pool, 1924 crop]

\begin{tabular}{|c|c|c|c|c|c|c|c|}
\hline Grade & $\begin{array}{l}\text { Bankers' } \\
\text { valuation }\end{array}$ & $\begin{array}{l}\text { Green } \\
\text { sales }\end{array}$ & $\begin{array}{l}\text { Redried } \\
\text { sales } \\
\text { (green } \\
\text { basis) }\end{array}$ & $\begin{array}{l}\text { Cost of } \\
\text { redrying }\end{array}$ & $\begin{array}{l}\text { Redried } \\
\text { sales } \\
\text { price } \\
\text { less cost } \\
\text { of redry- } \\
\text { ing }\end{array}$ & $\begin{array}{l}\text { Cost of } \\
\text { carrying }\end{array}$ & $\begin{array}{l}\text { Net price } \\
\text { of redried } \\
\text { tobacco }\end{array}$ \\
\hline 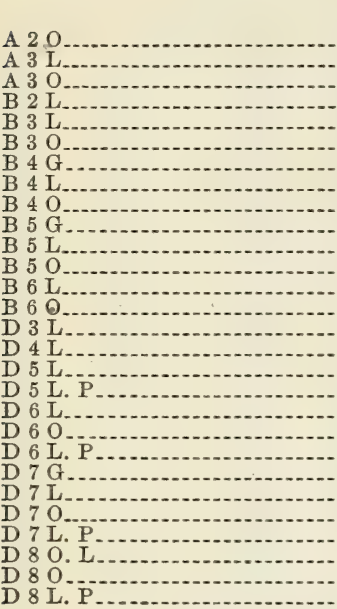 & $\begin{array}{r}\text { Dollars } \\
65.00 \\
50.00 \\
50.00 \\
43.00 \\
32.00 \\
32.00 \\
24.00 \\
24.00 \\
24.00 \\
16.00 \\
16.00 \\
16.00 \\
10.00 \\
10.00 \\
48.00 \\
40.00 \\
37.00 \\
37.00 \\
32.00 \\
32.00 \\
32.00 \\
28.00 \\
28.00 \\
28.00 \\
28.00 \\
24.00 \\
24.00 \\
24.00\end{array}$ & $\begin{array}{r}\text { Dollars } \\
67.07 \\
57.00 \\
40.81 \\
46.00 \\
31.63 \\
28.19 \\
26.01 \\
24.01 \\
21.50 \\
18.06 \\
17.91 \\
17.10 \\
13.00 \\
14.11 \\
50.00 \\
43.00 \\
39.64 \\
39.00 \\
30.77 \\
30.44 \\
31.59 \\
30.00 \\
27.66 \\
26.87 \\
26.86 \\
24.03 \\
22.88 \\
22.54\end{array}$ & $\begin{array}{r}\text { Dollars } \\
68.52 \\
54.54 \\
53.36 \\
48.18 \\
37.33 \\
36.76 \\
26.09 \\
26.01 \\
25.91 \\
19.21 \\
19.60 \\
17.26 \\
15.34 \\
13.70 \\
50.91 \\
46.38 \\
38.39 \\
38.18 \\
33.64 \\
34.95 \\
33.64 \\
30.05 \\
30.20 \\
29.40 \\
29.87 \\
26.57 \\
27.27 \\
26.12\end{array}$ & $\begin{array}{r}\text { Dollars } \\
3.72 \\
3.72 \\
3.72 \\
3.72 \\
3.72 \\
3.72 \\
3.72 \\
3.72 \\
3.72 \\
3.72 \\
3.72 \\
3.72 \\
3.72 \\
3.72 \\
3.72 \\
3.72 \\
3.72 \\
3.72 \\
3.72 \\
3.72 \\
3.72 \\
3.72 \\
3.72 \\
3.72 \\
3.72 \\
3.72 \\
3.72 \\
3.72\end{array}$ & $\begin{array}{r}\text { Dollars } \\
64.80 \\
50.82 \\
49.64 \\
44.46 \\
33.61 \\
33.04 \\
22.37 \\
22.29 \\
22.19 \\
15.49 \\
15.88 \\
13.54 \\
11.62 \\
9.98 \\
47.19 \\
42.66 \\
34.67 \\
34.46 \\
29.92 \\
31.23 \\
29.92 \\
26.33 \\
26.48 \\
25.68 \\
26.15 \\
22.85 \\
23.55 \\
22.40\end{array}$ & $\begin{array}{r}\text { Dollars } \\
1.98 \\
1.56 \\
1.52 \\
1.36 \\
1.03 \\
1.01 \\
.68 \\
.68 \\
.68 \\
.47 \\
.49 \\
.41 \\
.36 \\
.31 \\
1.44 \\
1.31 \\
1.06 \\
1.05 \\
.92 \\
.96 \\
.92 \\
.81 \\
.81 \\
.79 \\
.80 \\
.70 \\
.72 \\
.69\end{array}$ & $\begin{array}{r}\text { Dollars } \\
62.82 \\
49.26 \\
48.12 \\
43.10 \\
32.58 \\
32.03 \\
21.69 \\
21.61 \\
21.51 \\
15.02 \\
15.39 \\
13.13 \\
11.26 \\
9.67 \\
45.75 \\
41.35 \\
33.61 \\
33.41 \\
29.00 \\
30.27 \\
29.00 \\
25.52 \\
25.67 \\
24.89 \\
25.35 \\
22.15 \\
22.83 \\
21.71\end{array}$ \\
\hline
\end{tabular}

TABLE 61.-Inventory of tobacco stocks in the hands of the Tobacco Growers' Cooperative Association on the date of the receivership

\begin{tabular}{|c|c|c|c|c|c|c|}
\hline Pool and class & \multicolumn{2}{|c|}{1922 crop } & \multicolumn{2}{|c|}{1923 crop } & \multicolumn{2}{|c|}{1924 crop } \\
\hline $\begin{array}{l}\text { Dark-fired: Redried........... } \\
\text { Old belt: Redried. } \\
\text { Eastern Carolina: Redried..... } \\
\text { South Carolina: Redried...... }\end{array}$ & $\begin{array}{r}\text { Pounds } \\
706,612 \\
313,491 \\
\end{array}$ & \begin{tabular}{c} 
Value 1 \\
$\$ 142,648.79$ \\
$80,604.16$ \\
\hdashline
\end{tabular} & $\begin{array}{c}\text { Pounds } \\
5,869,457 \\
3,166,398 \\
\\
\end{array}$ & \begin{tabular}{c} 
Value 1 \\
$\$ 1,408,084.49$ \\
$844,726.43$ \\
\hdashline
\end{tabular} & $\begin{array}{r}\text { Pounds } \\
8,815,579 \\
15,117,003 \\
445,424 \\
207,932\end{array}$ & $\begin{array}{c}\text { Value } 1 \\
\$ 2,544,581.37 \\
3,344,022.19 \\
126,357.21 \\
39,374.13\end{array}$ \\
\hline Total. & $1,020,103$ & $223,252.95$ & $9,035,855$ & $2,252,810.92$ & $24,585,938$ & $6,054,334.90$ \\
\hline \multicolumn{3}{|c|}{ Pool and class } & \multicolumn{2}{|c|}{1925 crop } & \multicolumn{2}{|c|}{ Total } \\
\hline $\begin{array}{l}\text { Sun-cured: Redried....... } \\
\text { Dark-fired: Green } \\
\text { Dark-fired: Redried........ } \\
\text { Old belt: Redried. } \\
\text { Eastern Carolina: Redried. } \\
\text { South Carolina: Redried.. }\end{array}$ & & . & $\begin{array}{r}\text { Pounds } \\
95,604 \\
2,686,809 \\
5,762,168 \\
24,759,788 \\
1,436,892 \\
931,738\end{array}$ & $\begin{array}{c}\text { Value } 1 \\
\$ 40,506.91 \\
672,098.67 \\
1,161,434.66 \\
3,510,505.13 \\
466,439.57 \\
125,735.82\end{array}$ & \begin{tabular}{r}
\multicolumn{1}{r}{ Pounds } \\
95,604 \\
$2,686,809$ \\
$21,153,816$ \\
$43,356,680$ \\
$1,882,316$ \\
$1,139,670$
\end{tabular} & $\begin{array}{c}\text { Value } 1 \\
\$ 40,506.91 \\
672,098.67 \\
5,256,749.31 \\
7,779,857.91 \\
592,796.78 \\
165,109.95\end{array}$ \\
\hline Total & & & $35,672,999$ & $5,976,720.76$ & $70,314,895$ & $14,507,119.53$ \\
\hline
\end{tabular}

\footnotetext{
${ }^{1}$ Bankers' valuation.
} 


\section{LITERATURE CITED}

(1) Anonymous.

1927. the facts about тhe товасco association. Prog. Farmer, Car.Va. Ed. 42 (4) : 80 (4)-81 (5), 104 (28), 108 (32).

(2) BLATR, D. H.

1928. ANNUAL REPORT OF THE COMMISSIONER OF INTERNAL REVENUE, FISCAI YEAR ENDed JUNe 30,1928 . U. S. Treas. Dept., Commr, Int. Rev. Treas. Doc. $3000,152 \mathrm{p}$.

(3) Elsworth, R. H.

1928. AGRICULTURAL COOPERATIVE ASSOCIATIONS MARKETING AND PURCHASING-1925. U. S. Dept. Agr. Tech. Bul. 40, 98 p., illus.

(4) Garner, W. W., Moss, E. G., Yohe, H. S., Wilkinson, F. B., and Stine, O. C.

1923. history and status of tobacco culture. U. S. Dept. Agr. Yearbook 1922: 395-468, illus.

(5) GarnetT, W. E.

1927. RURAL ORGANIZATIONS IN RELATION TO RURAL LIFE IN VIRGINIA WITH SPECIAL REFERENCE TO ORGaNizational atTITUDES. Va. Agr. Expt. Sta. Bul. 256, 110 p., illus.

(6) Jesness, O. B.

1928. the CoOperative Marketing of tobacco. Ky. Agt. Expt. Sta. Bul, 288, p. 271-306.

( 7 ) North Carolina Departient of Agriculture, Tenancy Commission. 1923. ECONOMIC AND SOCIAL CONDITIONS OF NORTH CAROLINA FARMERS. 87 p. Raleigh.

(8) TAYLOR, H. M.

1927. virginia Fard Statistics 1926. Va. Farm Statis. Bul. 4, 85 p., illus.

(9) United States Departament of Agriculture.

1924. Agricultural statistics. U. S. Dept. Agr. Yearbook 1923: 867.

(10) United States Department of Commerce, Btreau of the Census.

1927. UNITED STites CENStS OF AGRICULTURE 1925. 3 v., illus. Washington [D. C.].

(11)

1922-23. FoURTEenth CENSUS OF THE UNITED StATES . . 1920. 11 v. Washington [D. C.].

(12) Uxited States Congress.

1926. REPORT OF THE FEDERAL TRADE COMMISSION ON THE TOBACCO INDUSTRY. U. S. Congress, 69th, 1st sess., Senate Doc. 34, 129 p.

(13) United States Federal Trade Commission.

1921. REPORT OF THE FEDERAL TRADE COMMIISSION ON THE TOBACCO INDUSTRY DECEMBER 11, 1920. $162 \mathrm{p}$.

(14) Verxox, J. J., and Ezekiel, M. J. B.

1925. CAUSES OF PROFIT OR LOSS ON VIRGINIA TOBACCO FARMS. Va. Agr. Expt. Sta. Bul. 241, 71 p., illus.

(15) Zimmeriran, C. C., and TAylor, C. C.

1922. RLPAL ORGANIZATION : A STUDY OF PRIMARY GROUPS IN WAKE COUNTY, N. C. N. C. Agr. Expt. Sta. Bul. 245, 42 p., illus. 


\section{ORGANIZATION OF THE \\ UNITED STATES DEPARTMENT OF AGRICULTURE}

OCTOBER 26, 1929

Secretary of Agriculture ARthur M. Hyde.

Assistant Secretary R. W. Dunlap.

Director of Scientific Work A. F. Woons.

Director of Regulatory Work Walter G. Campbell. Director of Extension Work C. W. Warburton:

Director of Personnel and Business Adminis- W. W. STOCKBERGER. tration.

Director of Information. M. S. EISENHOWER.

Solicitor. R. W. WILliams.

Weather Bureau_ Charles F. Marvin, Chief.

Bureau of Animal Industry JoHN R. MoHLER, Chief.

Bureau of Dairy. Industry O. E. REBD, Chief.

Bureau of Plant Industry Willtam A. Taylor, Chief.

Forest Service R. Y. Stuart, Chief.

Bureau of Chemistry and Soils H. G. KNight, Chief. Bureau of Entomology C. L. Marlatt, Chief.

Bureau of Biological Survey Paul G. Redington, Chief.

Bureau of Public Roads Thomas H. MacDonald, Chief.

Bureau of Agricultural Economics. Nils A. OLsEn, Chief.

Bureau of Home Economics. Louise Stanley, Chief. Plant Quarantine and Control Administration_ Grain Futures Administration. C. L. MarLatT, Chief. Train Futures Administration- W. DUVEL, Chief Food, Drug, and Insecticide Administration -- WALTER G. CAMPBELL, Director of Regulatory Work, in Charge.

Office of Experiment Stations. E. W. Allen, Chief.

Office of Cooperative Extension Work C. B. Sмmтн, Chief.

Library Claribel R. Barnett, Librarian.

This circular is a contribution from

Bureau of Agricultural Economics. Division of Cooperative Marketing

152
NIIS A. OLSEN, Chief.

Chris L. Christensen, Principal Agricultural Economist, in Charge. 
. 


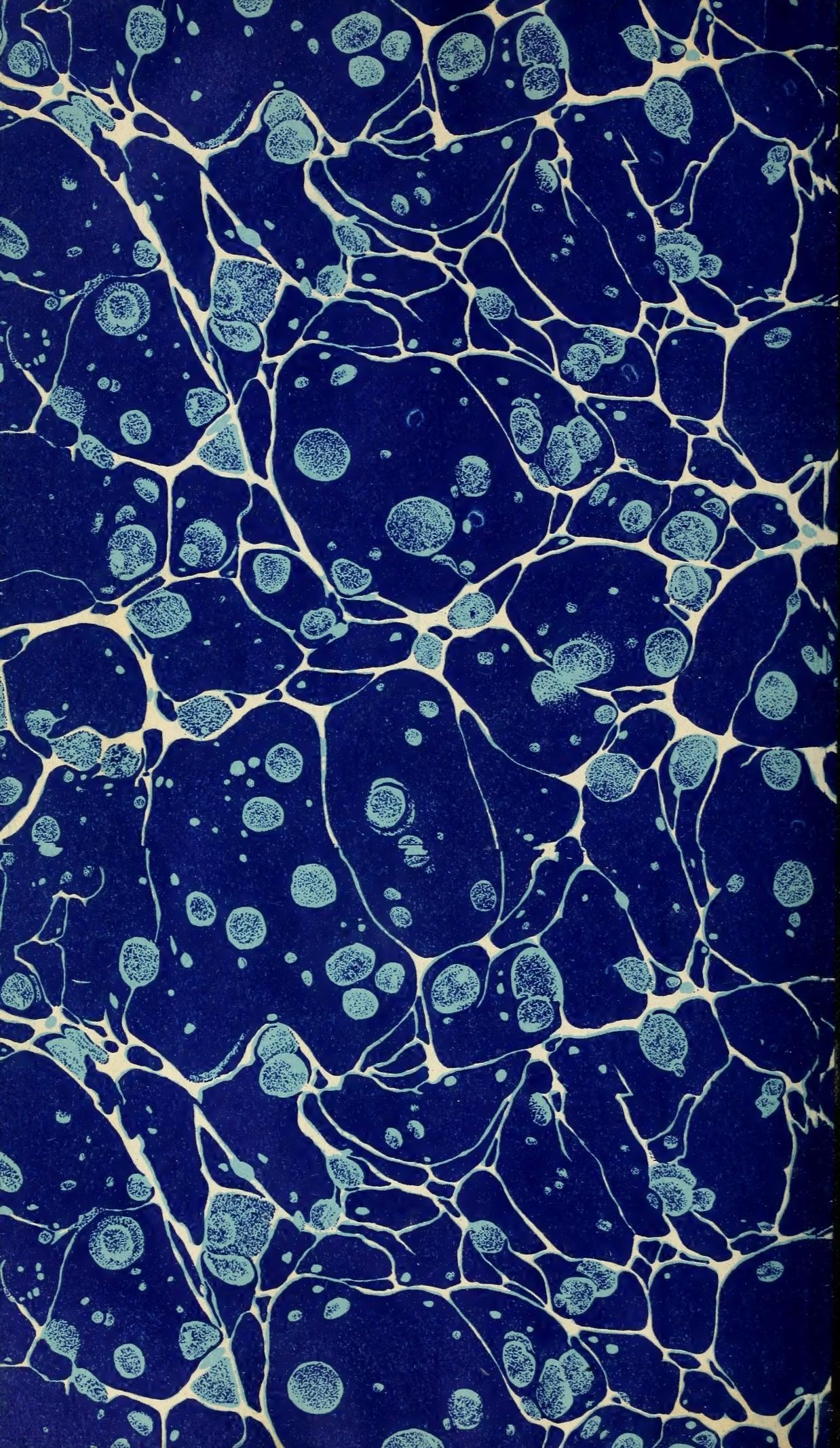




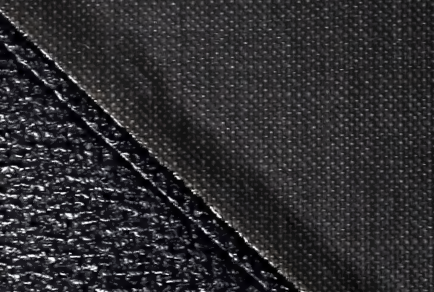

